\title{
A relação entre o Estado e os sindicatos sob uma perspectiva territorial
}

\author{
Amir El Hakim de Paula
}

PAULA, AEH. A relação entre o Estado e os sindicatos sob uma perspectiva territorial [online]. São Paulo: Editora UNESP, 2015, 261 p. ISBN 978-85-68334-67-6. Available from SciELO Books $<\underline{\text { http://books.scielo.org }>\text {. }}$

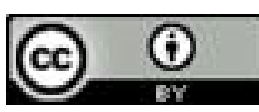

All the contents of this work, except where otherwise noted, is licensed under a Creative Commons Attribution 4.0 International license.

Todo o conteúdo deste trabalho, exceto quando houver ressalva, é publicado sob a licença Creative Commons Atribição 4.0.

Todo el contenido de esta obra, excepto donde se indique lo contrario, está bajo licencia de la licencia Creative Commons Reconocimento 4.0. 


\section{A relaÇÃo entre O ESTADO E OS SINDICATOS SOB UMA PERSPECTIVA TERRITORIAL}




\title{
FUNDAÇÃO EDITORA DA UNESP
}

\author{
Presidente do Conselho Curador \\ Mário Sérgio Vasconcelos \\ Diretor-Presidente \\ Jézio Hernani Bomfim Gutierre \\ Editor-Executivo \\ Tulio Y. Kawata \\ Superintendente Administrativo e Financeiro \\ William de Souza Agostinho \\ Conselho Editorial Acadêmico \\ Áureo Busetto \\ Carlos Magno Castelo Branco Fortaleza \\ Elisabete Maniglia \\ Henrique Nunes de Oliveira \\ João Francisco Galera Monico \\ José Leonardo do Nascimento \\ Lourenço Chacon Jurado Filho \\ Maria de Lourdes Ortiz Gandini Baldan \\ Paula da Cruz Landim \\ Rogério Rosenfeld \\ Editores-Assistentes \\ Anderson Nobara \\ Jorge Pereira Filho \\ Leandro Rodrigues
}




\section{AMIR EL HAKIM DE PAULA}

\section{A relaÇão entre O}

EsTADO E OS SINDICATOS

\section{SOB UMA PERSPECTIVA} TERRITORIAL 


\section{(C) 2015 Editora Unesp}

Direitos de publicação reservados à:

Fundação Editora da Unesp (FEU)

Praça da Sé, 108

01001-900 - São Paulo - SP

Tel.: (0xx11) 3242-7171

Fax: (0xx11) 3242-7172

www.editoraunesp.com.br

www.livrariaunesp.com.br

feu@editora.unesp.br

CIP - Brasil. Catalogação na Publicação

Sindicato Nacional dos Editores de Livros, RJ

P346r

Paula, Amir El Hakim de

A relação entre o Estado e os sindicatos sob uma perspectiva territorial [recurso eletrônico] / Amir El Hakim de Paula. - 1. ed. - São Paulo:

Editora da Unesp Digital, 2015.

recurso digital

Formato: ePub

Requisitos do sistema: Adobe Digital Editions

Modo de acesso: World Wide Web

ISBN 978-85-68334-67-6 (recurso eletrônico)

1. Sindicalismo - Brasil. 2. Livros eletrônicos. I. Título.

$15-28476$

CDD: 331.880981

CDU: $331.105 .44(81)$

Este livro é publicado pelo projeto Edição de Textos de Docentes e Pós-Graduados da UNESP - Pró-Reitoria de Pós-Graduação da UNESP (PROPG) / Fundação Editora da UNESP (FEU).

Editora afiliada:

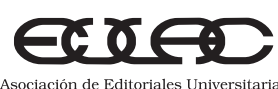

Asociación de Editoriales Universitarias

de América Latina y el Caribe

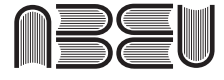

Associação Brasileira de Editoras Universitárias 
Ao meu pai (in memoriam) 


\section{Sumário}

Lista de mapas e tabelas 9

Lista de siglas 11

Agradecimentos 13

Introdução 15

1 - Metodologia de pesquisa 23

1.1 Meios de pesquisa 23

1.2 Território e territorialidade: conceitos fundamentais 31

2 - O Estado liberal e suas relações com o movimento operário no Brasil 43

2.1 A emergência das ideias liberais e a crítica do movimento operário 45

2.2 A influência do liberalismo e do federalismo nas elites brasileiras 65

3 - A ação territorial dos sindicatos-revolucionários sob o Estado liberal 87

3.1 O movimento sindical no início do século XX no Brasil 88

3.2 As territorialidades do movimento sindical no Brasil até o Início da década de 1920114

3.3 As greves de solidariedade e a questão territorial 152 
4 - A formação de um Estado corporativo e o movimento sindical no pós-1930 no Brasil 173

4.1 A ação estatal e o controle dos sindicatos no Brasil 186

4.2 A intervenção nos sindicatos na década de 1930 e a formação do Estado corporativo no Brasil 197

5 - As territorialidades dos sindicatos e a ação estatal nos anos de $1930 \quad 215$

5.1 Os sindicatos de orientação anarquista e a intervenção estatal-corporativa 218

5.2 Os efeitos da legislação sindical sobre a ação territorial dos sindicatos oficias 226

5.3 A ação territorial dos sindicatos oficiais no contexto do corporativismo 237

Considerações finais 245

Referências bibliográficas 251 


\section{LISTA DE MAPAS E TABELAS}

Mapa 1 - Entidades participantes dos congressos operários 146

Mapa 2 - Organização regional do $3^{\circ}$ congresso operário 148

Mapa 3 - Reelaboração da demonstração gráfica da organização da comissão executiva do $3^{\circ}$ congresso 149

Mapa 4 - Organização operária na Companhia Paulista de Estrada de Ferro 162

Mapa 5 - Expansão territorial da greve geral de 1917 no Brasil 169

Mapa 6 - Expansão territorial da greve geral de 1917 em São Paulo 170

Tabela 1 - Entidades participantes do $1^{\circ}$ congresso operário brasileiro 116

Tabela 2 - Entidades participantes do $2^{\circ}$ congresso operário brasileiro 119

Tabela 3 - Entidades participantes do $3^{\circ}$ congresso operário brasileiro 143

Tabela 4 - Número de sindicatos reconhecidos anualmente entre 1931 e $1936 \quad 201$

Tabela 5 - Entidades participantes da 3a conferência operária estadual 219 


\section{LISTA DE SIGLAS}

AIB Ação Integralista Brasileira

AIT Associação Internacional dos Trabalhadores

ANL Ação Nacional Libertadora

BOC Bloco Operário-Camponês

Cedem Centro de Documentação e Memória da UNESP.

CGT Confederação Geral do Trabalho - Brasil

CGT Confederation Generale Du Travail- França

CNG Conselho Nacional de Geografia

COB Confederação Operária Brasileira

CSCB Confederação Sindicalista-Cooperativista

Brasileira

DOPS Departamento de Ordem Política e Social

FOA Federação Operária de Alagoas

FORGS Federação Operária do Rio Grande do Sul

FOSP Federação Operária de São Paulo

IBGE Instituto Brasileiro de Geografia e Estatística

ISV Internacional Sindical Vermelha

PCB Partido Comunista do Brasil

POSDR Partido Operário Social-Democrata Russo

Unesp Universidade Estadual Paulista

Unicamp Universidade Estadual de Campinas

UTG União dos Trabalhadores Gráficos 


\section{Agradecimentos}

À professora doutora Léa Francesconi, em primeiro lugar, por abrir as portas da pós-graduação, acreditando no meu potencial para realização do mestrado e agora do doutorado. Também sou grato à professora por me auxiliar cotidianamente nesse percurso, permitindo que desenvolvesse essa pesquisa com grande liberdade.

Aos professores Marcelo Lopes, Antonio Thomaz, Marcelo Carvalhal, que estiveram presentes nesse percurso na discussão em seminários, colóquios, encontros nacionais e regionais.

Ao professor Dieter que me aceitou no Programa de Aperfeiçoamento de Ensino. Suas conversas no Departamento foram importantes para o meu amadurecimento intelectual.

À minha família, principalmente à minha mãe que, mesmo não entendendo o significado de se fazer um doutorado, soube na sua simplicidade me ajudar para que tudo desse certo.

À Adriana Aparecida Santana, por compreender a importância dessa pesquisa e, ao pacientemente ouvir minhas angústias, propor algumas soluções. Te amo!

Aos meus amigos e amigas Rogério Dezem, Rosângela Kimura, Silvia Lopes, Geraldo Damasceno, Paula, Ricardo Rugai (esse é dos antigos), que, de alguma forma, colaboraram na leitura prévia do texto, na correção gramatical etc.; a todos agradeço, de coração, a contribuição. 
Ao Erivaldo Costa, à Claudia Blanco, ao Carlos e ao Anderson Prado, por me ajudarem na confecção dos mapas.

Aos meus amigos Ailton Laurentino, Herodes Beserra, Francisco Lima, Marcelo Alessandro, Adriano Skoda e Rodrigo Rosa, que conversaram, discutiram ou até mesmo em pensamento me auxiliaram nessa pesquisa.

Aos funcionários da Secretaria de Pós-Graduação, da Biblioteca Florestan Fernandes, do Cedem-Unesp, do Arquivo do Estado, do Arquivo Nacional, da Biblioteca da Faculdade de Direito-USP, sou grato por me auxiliarem de alguma forma.

Ao grupo de estudos do Labur, que possibilitou momentos de reflexão e também de descontração.

À Capes, por auxiliar financeiramente a pesquisa de doutorado.

A todos aqueles e aquelas que me auxiliaram nessa produção e que, por um lapso de memória, não estão citados nominalmente. Todos vocês foram muito importantes! 


\section{INTRODUÇÃO}

Esta obra procurou compreender as relações entre o Estado e os sindicatos, tendo como ponto principal de análise as restrições que as entidades de trabalhadores sofreram na passagem de um Estado liberal para outro de estrutura corporativa.

Os estudos sobre o sindicalismo brasileiro tiveram um aumento qualitativo nos últimos anos na Geografia, surgindo inúmeras dissertações e teses sobre a estrutura e funcionamento, principalmente, dos sindicatos rurais no país. Dentre esses estudos, poderíamos citar o trabalho de Thomaz Jr. (1996), que em sua tese de doutoramento estudou a territorialidades da organização sindical dos trabalhadores do setor sucroalcooleiro. Sua contribuição se deu também por meio de orientação de dissertações e teses, possibilitando o aumento das pesquisas sobre sindicatos no país. ${ }^{1}$

Poucos foram os geógrafos que procuraram entender a organização dos trabalhadores urbanos do início do século XX. Moreira (1985), ainda na década de 1980, assinalava que

no campo da Geografia, esses estudos são praticamente inexistentes.

O operariado, enquanto classe e sujeito-objeto da história, merece vaga referência, e é confundido no tema genérico da população. (Moreira, 1985, p.21)

1 Entre esses trabalhos, temos o de Carvalhal, T. (2004) e o de Carvalhal, M. (2000). 


\section{AMIR EL HAKIM DE PAULA}

Mais recentemente, alguns trabalhos, como os de Camargo (2003) e Franca (2004), se preocuparam em investigar as relações de trabalho na indústria, embora não tendo como objetivo central as discussões acerca da organização sindical brasileira.

Nosso principal objeto de análise é a mudança de territorialidade sindical que ocorre no período compreendido entre o início do século XX até meados da década de 1930. Mais especificamente, essa pesquisa compreenderá de que forma o Estado e os sindicatos atuavam no território: as entidades de classe utilizando-o enquanto suporte para as estratégias organizacionais (como as greves), e o Estado, principalmente a partir de 1931, normatizando-o em busca de uma maior centralização do poder e, consequentemente, dificultando as ações de vários setores da sociedade civil, os sindicatos entre eles.

Ao estudarmos as relações entre os sindicatos e o Estado no território, objetivamos compreender como as entidades representantes dos trabalhadores organizavam suas ações territoriais (em nível municipal, estadual e nacional) e de que forma o Estado interferia nessas ações. Para isso, os conceitos de território e territorialidade assumem importância central.

O recorte temporal justifica-se na medida em que propicia uma visão das ações sindicais no território, seja na prevalência de um Estado liberal - quando a presença estatal nas relações entre o capital e o trabalho resumia-se na repressão às manifestações operárias, sem interferir na organização interna e de relacionamento entre os sindicatos, havendo grande pluralidade de entidades -, seja também no limiar de existência de um Estado corporativo - quando a interferência estatal restringia sensivelmente o raio de ação dessas entidades operárias, culminando com o fim da pluralidade sindical e o estabelecimento de uma ação sindical única.

Nessa pesquisa procuramos entender o significado dessas ações dos sindicatos no território nacional no que tange, principalmente, à busca dessas entidades por uma integração mais efetiva (como a constituição de encontros nacionais). Esses processos de articulação territorial entre os sindicatos tinham como escopo central a superação dos vários obstáculos existentes, como aqueles ocasionados pela 
dimensão territorial do país, agravado pela presença de uma precária rede de transportes e telecomunicações.

Além disso, essas entidades lutavam cotidianamente contra a repressão do Estado e dos patrões, como também contra a falta de recursos monetários, o que dificultava suas lutas por melhores condições de sobrevivência. Sendo assim, optamos por estudar prioritariamente os sindicatos-revolucionários, ${ }^{2}$ por serem opostos às políticas sociais e trabalhistas vigentes no período. Isto porque sempre tiveram uma ação anti-institucional (gerando várias lutas sociais) e a preocupação de organizar seus filiados nas várias escalas existentes (como a municipal, intermunicipal, regional, nacional e internacional).

Essa opção deveu-se também ao fato de que queremos compreender o real uso do território por essas entidades, pois suas ações são, além das citadas acima, mais horizontalizadas, federalistas e claramente antiestatais. Procuramos ainda apreender como uma legislação sindical incipiente no país, aliada a uma organização sindical de predominância sindicalista-revolucionária, possibilitou uma forma de abordagem territorial plural. É por esse motivo que nosso trabalho se estende até a década de 1930, quando então chegava ao poder Getúlio Vargas e, como demonstraremos, iniciava-se um maior controle dos sindicatos, com o Estado procurando, por meio da unicidade sindical, ${ }^{3}$ subjugar essas territorialidades mais espontâneas.

2 Ao tratarmos dos sindicatos-revolucionários nesta obra, estamos levando em consideração a forma pela qual essa tendência se apresentava entre os operários. Nesse sentido, não se trata pura e simplesmente de uma adjetivação, como poderia parecer ao leitor leigo. Desta forma, para não parecer estarmos adjetivando o nome sindicato, como, por exemplo, no caso de sindicatos reformistas, resolvemos apresentar essa tendência sindical como "sindicalismo-revolucionário" em vez de "sindicalismo revolucionário".

3 "Unicidade sindical” é um modelo no qual só pode haver um sindicato representando uma categoria profissional por base territorial. Contrapõe-se à "pluralidade sindical", modelo pelo qual vários sindicatos podem representar uma mesma categoria na mesma base territorial. A unicidade sindical foi instituída pelo governo de Getúlio Vargas, quando da criação do Ministério do Trabalho, sendo uma das normatizações desse período que vigora até hoje. 
As motivações que levaram a esse trabalho partiram de nosso interesse em um aprofundamento maior do estudo sobre o sindicalismo brasileiro. Essa proposta de análise surgiu durante o bacharelado em Geografia, quando realizamos uma pesquisa acerca das origens do movimento operário no Brasil, como trabalho de conclusão de curso.

Desde então, nossas pesquisas se remetem a esse temário (operariado no Brasil), seja na análise macroespacial, como no trabalho de conclusão de curso, ou numa pesquisa mais delimitada espaçotemporalmente, como em nossa dissertação de mestrado sobre o operário em São Paulo no início do século XX.

Afora o interesse pessoal, é importante frisar que na atualidade alguns debates ocorrem no Congresso Nacional e ressoam na opinião pública brasileira. Apresentam como foco a necessidade de mudanças nas relações entre o capital e o trabalho, como também a possibilidade de uma transformação na estrutura sindical atual, com as discussões sobre o fim da contribuição sindical e a volta da pluralidade sindical. ${ }^{4}$

Essas discussões trouxeram-nos também a preocupação em analisar as territorialidades dos sindicatos do início do século XX até a década de 1930, ou seja, analisar a transformação de uma estrutura sindical na qual predominava a pluralidade sindical para outra na qual predominava (e predomina até hoje) um único sindicato por categoria e base territorial.

Dentre as mudanças ocorridas no início da década de 1930, nos interessam principalmente aquelas que se referem à intervenção do Estado nos sindicatos e que alteraram as formas de relacionamento

4 Em 2005, o Executivo apresentou na Câmara dos Deputados o projeto de emenda constitucional n.369, tendo como relator o deputado federal Maurício Rands (PT-PE). A proposta visa implementar uma ampla reforma sindical e tem como base as discussões ocorridas no Fórum Nacional do Trabalho (FNT), coordenado pela Secretaria de Relações do Trabalho do Ministério do Trabalho e Emprego, que conta com a participação de 600 representantes de trabalhadores, governo e empregadores. 
existentes entre essas entidades, ${ }^{5}$ provocando o surgimento de uma ação sindical com fortes limitações territoriais. Com a chamada Revolução de $1930,{ }^{6}$ o governo que assumiu procurou realizar uma maior centralização do poder, diminuindo a força das oligarquias regionais, que aos poucos abandonavam os pressupostos liberais e anticentralistas que defendiam. ${ }^{7}$

Esse processo político questionava de muitas maneiras o federalismo predominante antes de 1930, determinando uma autonomia limitada aos estados da federação e, consequentemente, tornando o regime instalado cada vez mais centralizador. ${ }^{8}$ Nesse sentido, a Revolução de 1930, tendo como base essa maior centralização do poder, procurou limitar a ação territorial dos sindicatos, ao determinar um modelo único oficial, quase sempre restrito à escala municipal.

Essa intervenção do Estado na forma de organização dos sindicatos contribuiu para fragmentar suas lutas. Isso porque, a partir de 1931, surgiu ou foi transformada, derivada do decreto-lei n.19.770,

5 As motivações dessa ação estatal, bem como as suas características principais, são demonstradas mais adiante na discussão sobre as territorialidades dos sindicatos.

6 Sobre a importância da Revolução de 1930 e as mudanças ocorridas na política brasileira, ver: Decca (1981); Fausto (1997); Dulles (1977). Uma análise sobre o evento estará presente no Capítulo 4.

7 Com relação às burguesias urbanas, Araújo (2002, p.38) afirma que: "Trabalhos recentes chamaram a atenção para o fato de que, desde os anos 1920, o empresariado industrial desenvolveu um padrão de representação de interesses e de atuação política baseado fundamentalmente em suas associações de classe autônomas, que pode ser qualificado como um tipo de 'corporativismo privado'. Além dessa prática corporativa, suas lideranças mais expressivas desenvolveram, ao longo das décadas de 1920 e 1930, um discurso que, defendendo o tecnicismo, o nacionalismo econômico e o intervencionismo estatal, tinha muitos pontos convergentes com o projeto corporativo das elites que assumiram o poder em 1930".

8 Sobre esse processo de centralização do poder, diz Martin (1993): "Completouse assim, em 1937, um processo de recentralização do poder político iniciado sete anos atrás, o que viria a significar o fim da hegemonia paulista no governo federal. Mais uma vez, a centralização se identificaria com o unitarismo e o autoritarismo, como no Império (...)” (Martin, 1993, p.179). Para um maior detalhamento desse processo, ver também: Costa (1988). 
uma gama enorme de sindicatos pouco preocupados com as necessidades mais urgentes das suas categorias.

Mais ainda, ao aceitarem as prerrogativas da chamada lei de sindicalização, ${ }^{9}$ essas associações de trabalhadores defenderiam mais os interesses que contribuíssem para a sua manutenção enquanto uma entidade do que a categoria à qual elas estavam vinculadas, ocorrendo, então, pouca ou quase nenhuma relação territorial com suas congêneres (por exemplo, as entidades do Centro-Sul do país se relacionarem com as das regiões Norte e Nordeste). A intervenção do Estado nos sindicatos inibiu um maior contato entre as agremiações sindicais de uma mesma categoria, fazendo que os sindicatos fossem, na maioria das vezes, entidades isoladas e independentes (quando na verdade representavam a mesma profissão).

Outro fato relevante é que o Estado, ao inibir um maior contato entre os sindicatos, diminuía sensivelmente as greves de solidariedade, comuns até a década de $1920 .{ }^{10}$ A partir de uma melhor compreensão dessas mudanças políticas e sociais pelas quais passou o país, percebemos como as transformações ocorridas a partir de 1930 minaram a grande autonomia territorial dos sindicatos.

Resumidamente, esta obra apresenta inicialmente a metodologia e as bases teórico-conceituais (Capítulo 1) e, em seguida, os dois grandes momentos do período em questão: o Estado liberal e a organização dos operários (capítulos 2 e 3) e a formação do

9 Lei de Sindicalização era como os sindicatos mais combativos chamavam o decreto-lei n.19.770, de 19/3/1931. Nesta obra, em vários momentos, assumiremos a mesma denominação.

10 Essa intervenção estatal, que para Munakata (1984) foi de teor corporativista, teve o significado de "cercar com leis e regulamentos todo o terreno onde possa germinar a luta de classes, de modo a não deixar nenhuma brecha”. E completando o raciocínio, afirma que, com esse modelo de intervenção estatal nos sindicatos: "É preciso - e de acordo com a teoria corporativista - examinar profissão por profissão, isto é, as especificidades de cada corporação. Com isso dissolve-se a unidade da classe operária como um todo. [...] E, ao mesmo tempo, evita-se a eclosão de qualquer conflito particular organizado por especificidades de cada categoria” (Munakata, 1984, p.78-79). 
Estado corporativo e sua relação com as organizações sindicais (capítulos 4 e 5).

No Capítulo 1, procuramos discutir os principais instrumentos teóricos e práticos para a realização desta pesquisa. Demonstramos as principais fontes utilizadas, a nossa metodologia de análise dos jornais operários, esclarecemos a opção em analisar o movimento sindical como um todo e não uma categoria específica e, finalmente, apontamos de que forma os conceitos de território e territorialidade foram importantes para o entendimento de nosso trabalho.

No Capítulo 2, nossas atenções voltam-se para a compreensão do Estado liberal e do liberalismo, seus principais teóricos e ideais, como essas ideias chegaram ao Brasil e foram utilizadas pelas elites, mas também a crítica que o movimento operário contrapôs a essa ideologia.

No Capítulo 3, nossa análise tem como principal foco compreender as várias territorialidades presentes no movimento operário do início do século XX, principalmente aqueles que tinham o sindicalismo-revolucionário como aporte ideológico. Realizamos uma discussão histórica e geográfica das origens do movimento operário, os debates da I Internacional acerca do sindicalismo, até chegarmos ao movimento operário brasileiro e entendermos como os sindicatos de trabalhadores agiam perante a legislação sindical, a qual lhes possibilitava certa autonomia no que diz respeito às suas relações territoriais. Como forma de demonstrar essas territorialidades, no final desse capítulo, discutimos também dois eventos de grande importância para o período: a greve dos ferroviários de 1906 e a greve geral de 1917.

No Capítulo 4, discutimos as principais ideias do corporativismo no mundo, a crítica às ideias liberais por parte de vários intelectuais tanto estrangeiros como nacionais, o surgimento de um pensamento conservador no país na década de 1920, e como essas ideias deram suporte para uma maior intervenção do Estado nas relações entre o capital e o trabalho.

No Capítulo 5, nossas preocupações pautaram-se em discutir a forma pela qual as interferências estatais limitaram o alcance 
territorial das entidades de classe, demonstrando inclusive como o Ministério do Trabalho, criado em 1930, dificultava ao máximo a existência de sindicatos com base territorial maior que a de um município. O capítulo demonstra uma flagrante transformação das territorialidades dos sindicatos, que passaram a ser controladas internamente pelo Estado, o que também gerou um enfraquecimento nas suas ações territoriais.

Para nós, esse pequeno trabalho terá cumprido sua missão se conseguir, ao seu final, demonstrar a importância da Geografia em analisar os movimentos sociais e, principalmente, de que forma os movimentos sociais podem se utilizar dos instrumentais geográficos para a construção de uma sociedade melhor. 


\section{1 \\ Metodologia de pesouisa}

\section{1 - Meios de pesquisa}

As origens do movimento operário e sindical no Brasil remontam ainda ao final do século XIX, quando da formação das primeiras entidades de auxílio mútuo, quase sempre ligadas às categorias mais fortes. ${ }^{1}$

Com a organização dos trabalhadores em entidades de resistência no início do século XX, percebe-se que o operariado, ainda que mantivesse várias prerrogativas das entidades beneficentes, como auxílio aos funerais de um filiado, já tinha a clareza que só conquistaria melhores salários e condições de trabalho se se contrapusesse ao capital.

Como forma de conseguirem se articular e demonstrarem as suas ações cotidianas, essas entidades, quando seus recursos financeiros permitiam, fundavam jornais, que, além de funcionarem como uma propaganda da atuação do sindicato, propiciavam uma melhor articulação das entidades combativas, como na formação de uniões operárias locais, federações regionais e estaduais e confederação nacional.

Em que pese a abnegação dos militantes operários desse período, caso de Edgar Leuenroth, é notória a falta de periódicos sindicais

1 Mais detalhes sobre a formação dessas entidades, ver Simão (1966), principalmente o capítulo 4, sobre a organização sindical brasileira. 
do Norte e Nordeste do país (encontramos apenas exemplares de algumas capitais e cidades maiores), sendo que aqueles que apresentaram menor intermitência eram principalmente do Rio de Janeiro e de São Paulo.

Esse fato devia-se às dificuldades de organização dos sindicatos localizados nas regiões de menor industrialização, o que ocasionava uma menor presença sindical.

Com o apoio de alguns autores citados adiante, e tendo também a presença dos arquivos operários, detectamos que grande parte dos periódicos sindicais até meados da década de 1920 era de predominância anarquista e sindicalista-revolucionária. Isso pode significar uma presença mais coesa dessas entidades pelo país nesse período em estudo.

Até recentemente (início da década de 1990) historiadores e cientistas sociais declaravam os sindicatos mais combativos no Brasil como anarcossindicalistas. No presente trabalho, optamos por usar o termo "sindicalismo-revolucionário", mais presente nos trabalhos de Toledo (2004), ${ }^{2}$ visto que o anarcossindicalismo, de fato, não se estruturou no Brasil, como em outras nações latinas, casos da Espanha e de Portugal.

Entretanto, isso não significava que essa tendência (sindicalismo -revolucionário) não teria nenhum vínculo com o anarquismo, como pretende demonstrar essa autora, principalmente a partir do início da década de 1930, quando, como forma de demarcar as diferenças ideológicas com os comunistas, por exemplo, esses sindicatos já abertamente chamavam-se anarquistas. ${ }^{3}$

2 Segundo a autora, "o movimento operário em São Paulo no início do século, portanto, não pode ser reduzido ao movimento anarquista, uma vez que a experiência da classe operária paulista envolve diferentes ideias e comportamentos políticos, entre os quais se destaca o sindicalismo revolucionário, um movimento que, em várias partes do mundo, se transformara em uma corrente política autônoma em relação ao anarquismo e ao socialismo" (Toledo, 2004, p.27).

3 Nesta obra, esses sindicatos serão trabalhados a partir de 1930 como "sindicatos de orientação anarquista". 
Sobre isso, vejamos abaixo uma declaração da Federação Operária de São Paulo, ${ }^{4}$ entidade estadual que agregava vários sindicatos combativos, a favor do anarquismo (comunismo libertário) como forma de diferenciar-se das entidades de orientação comunista.

A Federação Operária de São Paulo e as organizações aderentes a ela mais de uma vez têm reafirmado o que consideram ser a sua missão principal: Destruir todo poder econômico e político e estabelecer uma sociedade que tenha por base o livre desenvolvimento do indivíduo sem sujeição a nenhum poder, a nenhuma absurda ditadura, seja ela branca, vermelha ou preta. Aspiramos ao comunismo libertário, verdadeiro ideal que nada tem de semelhante com pseudocomunismo russo. (Boletim da Federação Operária de São Paulo, 1/8/1931, p.1)

Levando-se em consideração que essas entidades sobreviviam apenas com a cotização de seus filiados, era comum nesse período inicial da formação da classe operária a intermitência na publicação de vários desses periódicos.

Entretanto, por representar várias categorias organizadas numa central, um jornal operário foi de extrema valia a nossa pesquisa. Isso se deveu a sua maior perenidade e a sua constante menção às ações dos sindicatos de resistência, mesmo que apenas numa parte do período estudado.

A Voz do Trabalhador, órgão oficial da Confederação Operária Brasileira (COB), foi importante para analisarmos as diversas territorialidades existentes. Entretanto, por ser tratar de um jornal de alcance nacional, nem sempre a mesma categoria aparecia nas suas páginas continuamente, em que pese em um período de oito anos (1908-1915) o jornal ter saído com uma regularidade semanal.

4 A Federação Operária de São Paulo (FOSP) foi uma organização estadual vinculada, até a década de 1920, ao sindicalismo-revolucionário e, na década de 1930, ao anarquismo. 
Além das fontes operárias, outro importante recurso para a compreensão da relação entre os sindicatos e o Estado foram as publicações oficias ou pró-governo Vargas.

Essas publicações estão organizadas conforme o ano de lançamento e, diferentemente dos periódicos sindicais, não apresentam intermitência no período de nosso estudo.

Duas delas foram valiosas para conseguirmos detectar qual foi a postura governamental, a partir de 1930, com relação à organização dos trabalhadores: a Revista do Trabalho e o Boletim do Ministério do Trabalho, Indústria e Comércio.

A Revista do Trabalho, embora não fosse um órgão oficial do governo, tinha grande simpatia pelas propostas oficiais e, por isso, em suas páginas publicava declarações de membros do governo e, principalmente, pareceres positivos ou não acerca dos vários pedidos dos sindicatos em processo de reconhecimento.

Já o Boletim do Ministério do Trabalho, Indústria e Comércio era uma publicação governamental com o intuito de divulgar oficialmente a legislação sindical e trabalhista. Nele encontramos também discursos sobre esse processo de oficialização dos sindicatos, palavras do Ministro do Trabalho sobre o momento por que passavam essas entidades, mas também agradecimentos de parte de alguns sindicalistas, o que possibilita perceber uma sintonia entre esses sindicatos e a proposta oficial.

As duas publicações foram importantes para entendermos de que forma o Estado, ao intervir nos sindicatos, preocupava-se também em restringir a territorialidade dessas entidades.

Outra fonte oficial desse período foram os prontuários do Dops (Departamento Estadual de Ordem Política e Social). Essa estrutura política foi criada em 1924 e tinha o objetivo de reprimir ou mesmo prevenir os atos considerados ofensivos à segurança do Estado.

Por meio dos relatórios dos investigadores e da presença de panfletos de alguns sindicatos, observamos de que forma a polícia agia na repressão ao movimento operário, mas também coletamos informações sobre algumas divergências entre os sindicatos mais combativos. 
É importante frisar que os estudos sobre o movimento sindical no Brasil no início do século XX são possíveis graças, principalmente, às presenças de grandes arquivos operários.

Essas pesquisas 5 iniciaram-se a partir da década de 1950, junto à presença de um extenso material de jornais operários conservados por militantes desse movimento, que mantinham em sua residência verdadeiros arquivos de periódicos.

Assim, as primeiras pesquisas históricas e sociológicas do movimento operário foram realizadas nos arquivos pessoais de Edgar Leuenroth e Astrojildo Pereira, dois dos maiores líderes operários das primeiras décadas do século XX.

Atualmente grande parte desses arquivos pessoais encontra-se no Cedem-Unesp e no Arquivo Edgar Leuenroth da Unicamp.

O arquivo da Unesp teve parte de seus documentos constituída na década de 1970, graças à preocupação de alguns brasileiros exilados na Itália em preservar a memória dos movimentos sociais.

Nesse caso, seus principais materiais foram primeiramente organizados na cidade de Milão, sob o nome de Asmob (Archivio Storico Del Movimento Operaio Brasiliano), e eram compostos pelos fundos Astrojildo Pereira, Roberto Morena, recebendo também doações de militantes comunistas como Luiz Carlos Prestes, Oscar Niemeyer e Jorge Amado, e também de exilados que lutavam contra a ditadura militar existente no Brasil. Esse arquivo operário foi doado à Unesp em 1994 e localiza-se na cidade de São Paulo.

Pioneiro no país, o Arquivo Edgar Leuenroth foi formado em 1974, na Unicamp, graças à aquisição do material guardado durante dezenas de anos por esse líder operário, sendo um dos mais importantes quando se trata de estudar esse tema.

Afora o Arquivo Edgar Leuenroth e o Arquivo Cedem, existe, ainda que parcialmente, o Centro de Memória Sindical, ligado ao Sindicato dos Têxteis da cidade de São Paulo.

5 Entre as pesquisas iniciais do movimento operário no Brasil, citamos como principais: Linhares (1977); Rodrigues (1969); Dias (1962). Esses autores eram antigos militantes comunistas ou anarquistas. 
Infelizmente, o acesso aos documentos mais antigos desse sindicato mostrou-se inviável, pois essa entidade, com o passar das gestões, destruiu parte de seus periódicos, não tendo a preocupação em conservar os jornais do período em estudo.

Foi com base nos arquivos operários que conseguimos analisar grande parte do material que ora apresentamos.

A intermitência de vários periódicos, bem como a inexistência de uma metodologia de análise dessas fontes, no que tange à ciência geográfica, exigiu de nós algumas operações como forma de dirimir essas dificuldades.

Para tanto, num primeiro momento, analisamos os principais autores que estudaram o movimento operário desse período, e a partir deles, recorremos a essas fontes primárias como forma de reunirmos o maior número de periódicos que nos interessassem.

Guzzo de Decca (1987), Hardman (1982) e Carone (1979) situam-se entre os pesquisadores que iniciaram, com dissertações e teses de doutorado, uma maior compreensão da história do operariado brasileiro, que era, principalmente, fabril.

Do enfoque sociológico, poderíamos citar Aziz Simão (1966), que antes mesmo da formação do Arquivo Edgard Leuenroth, graças à intensa amizade com o líder anarquista, realizou uma obra considerada marco na sociologia do trabalho, e até hoje, continua como um clássico acerca do movimento operário do início do século XX.

Esses estudos, quase sempre ligados à História ou à Sociologia, tiveram uma expansão qualitativa nas últimas duas décadas, que viram surgir inúmeras teses e dissertações que trouxeram novas nuances desse movimento social de grande expressão no início do século XX. ${ }^{6}$

A partir dessas pesquisas, optamos prioritariamente em analisar os sindicatos-revolucionários, já que eram as únicas entidades, até a segunda metade da década de 1920, com grande preocupação em lutar contra o capital.

6 Entre as pesquisas encontradas, temos: Lopreato (1996); Toledo (2002) e Biondi (2002). 
Ao contrário dos sindicatos-revolucionários, as entidades beneficentes/mutuais e as reformistas não professavam uma única ideologia, dificultando a sua análise enquanto um agrupamento sindical uniforme. Além disso, essas entidades pouco se preocupavam com a formação de uma organização nacional (ao contrário das sindicalistas-revolucionárias).

No caso dos sindicatos católicos, embora tivessem um corpo ideológico definido (as preleções da encíclica Rerum Novarum) não tinham uma orientação classista e de ruptura com o sistema capitalista.

Essa opção em trabalharmos com as entidades de resistência se deve ao fato de serem as mais representativas, no que tange aos confrontos que ocorriam entre o proletariado e a burguesia nascentes.

Essa priorização foi necessária e se mostrou (como veremos adiante, na análise territorial de algumas entidades) a melhor alternativa, visto detectarmos nos vários periódicos analisados a presença de uma intensa relação territorial entre sindicatos que professavam essa ideologia.

Como forma de não confundirmos um sindicato-revolucionário com os outros existentes, visto que alguns jornais portavam títulos parecidos, em que pese origens até divergentes, utilizamos obras de autores que não separaram as pesquisas da prática militante e por isso diferenciavam os grupos sindicais. ${ }^{7}$

Dentre esses, os principais foram Edgar Rodrigues e Everardo Dias. Ambos estão entre os primeiros a desenvolverem uma pesquisa detalhada sobre o movimento operário do início do século XX.

Outra obra importante para a análise de periódicos foi "A Imprensa Operária no Brasil” (1880-1920), de Ferreira (1978). Nesse

7 Um exemplo foi o jornal O Combate, de São Paulo, existente na década de 1910. Dirigido por Nereu Rangel Pestana, o periódico, embora tivesse um título que pudesse denotar algum compromisso mais forte com a classe operária, não professava qualquer programa ideológico que buscasse a ruptura com o sistema capitalista (como os anarquistas e os sindicalistas-revolucionários). Mesmo sendo simpático com as lutas operárias em suas páginas, questionava veementemente as ações violentas dos trabalhadores, fosse nas greves ou mesmo nos comícios. 
trabalho, a autora descreve os diversos jornais encontrados no Arquivo Edgar Leuenroth e relaciona-os com a ideologia à qual se afinavam.

Algo que merece um esclarecimento refere-se a escolha em discutir o movimento sindical, sem necessariamente se ater a um sindicato específico.

Isso se deveu à própria dificuldade de organização dos sindicatos no período em estudo, visto que essas entidades de classe mantinham-se somente por meio da cotização de seus filiados. Quando o número de aderentes diminuía, a própria sobrevivência da entidade ficava ameaçada.

Não é por acaso que, nos jornais analisados, eram comuns artigos comentando sobre as dificuldades de manutenção dessas entidades, sendo corrente, inclusive, que na própria ata de fundação aparecesse uma cláusula que discutia a doação de imóveis da entidade caso a mesma se extinguisse.

Essa incipiente organização dos trabalhadores ocasionava uma grande intermitência entre os jornais de diversas categorias, mesmo entre aqueles periódicos que eram mantidos graças aos esforços de vários sindicatos. Quando um periódico operário cessava a sua publicação (fosse por motivos econômicos ou depois das ações policiais) surgia também uma interrupção do registro histórico de várias entidades de classe, denotando que a história dessas categorias profissionais ficava quase que totalmente ligadas a essas informações.

Outra questão importante neste trabalho é compreender que os sindicatos-revolucionários, com a fundação do Partido Comunista, já não mais defenderiam a neutralidade das entidades sindicais, algo comum até o fim da década de 1910, como forma de não sofrerem maior assédio das ideias comunistas, e perderiam a influência sobre uma parte das organizações sindicais.

Desta forma, quando trabalharmos a presença sindical no período pós-1930, esses sindicatos estarão agrupados como sindicatos de orientação anarquista.

Entendemos que essa metodologia de análise, ainda que necessitando avanços, possibilitou-nos uma maior acurácia na pes- 
quisa que desenvolvemos, já que foram enormes os desafios que enfrentamos para compreender as territorialidades dos sindicatos desse período.

Por fim, gostaríamos de explicitar que, muito embora seja significativa a presença dos sindicatos de orientação comunista, a partir da metade da década de 1920, por uma opção metodológica (a possibilidade de comparação entre a pluralidade sindical e a unicidade sindical no que tange à questão territorial), essas agremiações não foram o principal objeto de nossa pesquisa.

Isso se deveu, principalmente, ao fato de os comunistas estarem iniciando efetivamente uma maior participação no movimento sindical apenas quase no final da década de 1920, pouco antes da intervenção estatal nos sindicatos. Desta forma, restaria um gradiente menor de tempo para a análise com o fim de demonstrar a sua organização territorial, ao contrário dos sindicatos-revolucionários ativos desde o início do século XX.

Além disso, o fato de defenderem a unicidade sindical e serem antifederalistas levava-os a terem uma prática sindical de menor movimentação territorial, se contrapondo às táticas anarquistas e sindicalistas-revolucionárias.

\section{2 - Território e territorialidade: conceitos fundamentais}

As bases teórico-metodológicas de nossa pesquisa são fruto de uma evolução acadêmica que se desenvolve desde a graduação. Desde então, nossas preocupações se dirigem para o entendimento do movimento operário brasileiro do início do século XX.

Na graduação, estudamos a configuração espacial dos sindicatos no país, quando então percebemos a carência de estudos geográficos sobre o tema, o que nos trouxe alguns desafios de cariz metodológico, principalmente pela necessidade de análise de algumas questões parcialmente desenvolvidas. 
No mestrado, nossas atenções continuaram voltadas aos estudos da classe operária, só que circunscritas à cidade de São Paulo, em momento marcado por grandes transformações urbanísticas.

Nessa dissertação, por meio dos conceitos de segregação espacial e apropriação, discutimos a relação entre os operários e a cidade, ou seja, estudamos as dificuldades de inserção desses trabalhadores na urbe (profissionalmente, culturalmente etc.) e como essa classe lutava por uma cidade sem segregação espacial, o que ocorria em momentos de grande agitação social, como a Greve Geral de 1917.

$\mathrm{Na}$ atual pesquisa, nossas preocupações metodológicas voltam-se para a discussão acerca dos conceitos de território e territorialidade e como ambos podem contribuir para o entendimento das relações entre os sindicatos e o Estado, principalmente quando da passagem de uma estrutura sindical presente no Estado liberal para outra de caráter corporativo.

Na história da ciência, os estudos sobre território e territorialidade foram objetos de preocupações de vastas áreas do conhecimento, como a botânica e a zoologia, por meio dos trabalhos naturalistas do século XVIII ou mesmo pela Etologia de Auguste Comte, para citar os mais conhecidos (Moraes, 1984).

O temário ganhou um significado importante para a ciência geográfica no final do século XIX e início do século XX, por meio dos trabalhos de Ratzel, principalmente na sua obra Politische Geographie, na qual postulava que

O Estado não é um organismo meramente porque ele represente uma união do povo vivo com o solo (Boden) imóvel, mas porque essa união se consolida, tão intensamente através de interação, que ambos se tornam um só e não podem mais ser pensados separadamente sem que a vida venha a se evadir. (Ratzel apud Souza, 1995, p.85)

Para o geógrafo alemão, o solo aparece como sinônimo de território, pois é na relação entre esse Boden e a sociedade que nele habita que está a origem do Estado-nação. Diz Ratzel sobre essa relação 
a sociedade que consideramos, seja grande ou pequena, desejará sempre manter sobretudo a posse do território sobre o qual e graças ao qual ela vive. Quando esta sociedade se organiza com esse objetivo ela se transforma em Estado. (Ratzel apud Candiotto, 2009, p.316)

Muito presente na Geografia (principalmente na Geografia Política), a vertente política teve sempre no país um papel destacado entre intelectuais brasileiros do início do século XX, como Backheuser, Elysio de Carvalho e Delgado de Carvalho, claramente influenciados pelas concepções de Ratzel. ${ }^{8}$

Essa concepção prioriza o papel do território (e sua organização) pelo pressuposto estatal, compreendendo qualquer outra manifestação no território, que não a estatal, como uma excepcionalidade, ou seja, uma ação "extraterritorial". 9

Entretanto, mais recentemente, outros autores buscaram diversas formas de entendimento sobre o território, poder e territorialidade. Dentre esses, encontramos Claude Raffestin e Paul Claval

Para Claval,

os geógrafos têm negligenciado as dimensões espaciais do poder em geral numa sociedade complexa, tendo até agora se apegado em excesso ao Estado em si, com isso passando ao largo de fatos impor-

8 Conforme comenta Miyamoto (1995, p.44-64), "as décadas de 1920 e 1930 corresponderam ao surgimento dos primeiros estudos nacionais sobre a geopolítica. [...] Este período se salientou por apresentar poucos autores: Elyseo de Carvalho, Everardo Backeuser, Carlos Delgado de Carvalho, Mario Travassos e Francisco de Paula, sendo os dois últimos militares. [...] A influência de Ratzel é visível em todos eles, mas nem sempre as concepções de espaço, posição e poder daquele autor, são interpretações à mesma luz pelos estudiosos nacionais".

9 As discussões sobre o que seria uma concepção de extraterritorialidades foram levantadas na disciplina "Formação territorial e teoria em Geografia Humana", ministrada pelo professor Antonio Carlos Robert Moraes, no segundo semestre de 2007, no Departamento de Geografia da FFLCH/USP. 
tantes relacionados às engrenagens dos governos e suas articulações com as sociedades civis. (apud Costa, 1988, p.24)

Outro expoente dessa tendência na Geografia, Raffestin (1993) aponta que o território, formando-se

a partir do espaço, é o resultado de uma ação conduzida por um ator sintagmático (ator que realiza um programa) em qualquer nível. Ao se apropriar de um espaço, concreta ou abstratamente (por exemplo, pela representação), o ator "territorializa" o espaço. (Raffestin, 1993, p.193)

Baseados largamente nas concepções foucaultianas ${ }^{10}$ de poder, esses autores divergem da ideia que admite o Estado como única fonte dotada de ação no território, como fica evidenciado nas suas críticas à chamada Geografia Política clássica.

Diz Raffestin (1993):

Em vez de se interessar por qualquer organização dotada de poder político suscetível de se inscrever no espaço, a Geografia Política só vive, e em consequência, só fez a análise de uma forma de organização: a do Estado. (Raffestin, 1993, p.28)

Dentro dessa perspectiva, por mais que o Estado ${ }^{11}$ seja, como afirma Gramsci, todo o complexo de atividades práticas e teóricas

10 O poder para Foucault não pode ser localizado em um único ponto, como o Estado, por exemplo. Ele é relacional, dinâmico, mantém ou destrói grandes esquemas de dominação, numa grande correlação de forças.

11 Para nós, o Estado não é uma resposta às necessidades de se mediar conflitos, como pensavam alguns cientistas sociais da escola liberal (casos de Locke e Smith). Pelo contrário, ele é um veículo do qual a classe dominante (no caso de nossa pesquisa, a burguesia industrial/cafeeira) se utilizava para oprimir as classes mais pobres, como os operários e suas entidades representativas. Essa repressão era feita de forma coercitiva, quando se fechavam as entidades e se proibiam as manifestações dos trabalhadores, ou de forma ideológica, quando 
com o qual a classe dominante não somente justifica e mantém seu domínio, mas procura conquistar o consentimento ativo daqueles sobre os quais exerce sua dominação, parcelas da sociedade civil organizada (como os sindicatos, por exemplo) nessa época lutavam para manter a sua autonomia e, de certa forma, divergiam abertamente do poder estatal.

Isso pode ocorrer porque, como afirma Raffestin (1993),

o Estado está sempre organizando o território nacional por intermédio de novos recortes, de novas implantações e de novas ligações. $\mathrm{O}$ mesmo se passa com as empresas ou outras organizações. [...] Em graus diversos, esses momentos diferentes e em lugares variados, somos todos atores sintagmáticos que produzem "territórios". (Raffestin, 1993, p.152-153)

A partir dessas teorizações, compartilhamos da hipótese de que as várias ações no território (sociais, econômicas, políticas e culturais) não se fixam apenas e tão somente na ação estatal, sendo que outros agentes sociais, como os sindicatos, por exemplo, aparecem como organismos de grande atuação no território, questionando em alguns casos a estrutura dominante determinada pelo poder central.

Sendo assim, como aponta Costa, W. (1988), as ações dessas entidades não podem ser ocultadas, visto que, muito embora a relação Estado-poder-território seja a mais evidente, "tais mecanismos, aqueles que interferem nessa relação [poder-território] desenvolvemse através das formas e organizações já conhecidas, como partidos, sindicatos, entidades etc." (Costa,W., 1988, p.24).

De certa forma influenciados pelas discussões suscitadas por Paul Claval e Claude Raffestin, surgem em algumas universidades brasileiras, a partir da década de 1990, inúmeros trabalhos acadêmicos (artigos, dissertações, teses) incorporando a esse debate

a elite se utilizava de recursos jurídicos, culturais, educacionais para impor seu modo de vida. Para mais detalhes, ver Carnoy (1994). 
novas (re)formulações acerca da conceituação clássica de território e territorialidade.

Dentre esses autores, destacamos aqueles que, ao promoverem uma nova abordagem do tema, propiciaram o surgimento de uma gama de trabalhos baseados numa ampliação desses conceitos e que, de certa forma, foram importantes para a nossa compreensão do tema de pesquisa. ${ }^{12}$

Haesbaert (2004) aponta pelo menos três concepções básicas de território: (i) a política ou jurídico-política, a mais difundida, na qual o território é visto como um espaço delimitado e controlado, por meio do qual se exerce um determinado poder, na maioria das vezes, mas não exclusivamente relacionado ao poder político do Estado; (ii) a cultural ou simbólica, na qual o território é visto, sobretudo, como o produto da apropriação/valorização de um grupo em relação ao seu espaço vivido; (iii) e a econômica, aquela que enfatiza a dimensão espacial das relações econômicas.

Ao ampliar as análises sobre território e seus agentes, Haesbaert (2004) discute também as diversas formas de territorialidades. Baseando-se nas análises de Sack (1980), o autor mostra que as territorialidades não deixam de ser uma estratégia de controle, visto que é a partir dessa ação no território que se pode controlar recursos ou mesmo impor novas relações.

Para ele, o conceito de territorialidade deve ser usado também

Para enfatizar as questões de ordem simbólica-cultural. Territorialidade, além da acepção genérica ou sentido lato, onde é vista como a simples qualidade de seu território, é muitas vezes concebida em um sentido estrito como a dimensão simbólica do território. (Haesbaert, 2004, p.74)

Outro autor importante em nossa discussão sobre território e territorialidade é Souza (1995). Para esse autor, é muito simplista

12 Dentre os autores brasileiros que seguiram uma abordagem crítica acerca dos conceitos de território e territorialidade temos Haesbaert (2002, 2004, 2007 e 2009) e Souza (1995, 2009). 
associar a ideia de território como pertencente apenas ao Estado, ou o Estado como o único agente do território, visto que

ele [o território] não precisa nem deve ser reduzido a essa escala ou à associação com a figura do Estado. Territórios existem e são construídos (e desconstruídos) nas mais diversas escalas, da mais acanhada (por exemplo, uma rua) à internacional (por exemplo, a área formada pelo conjunto dos territórios dos países-membros da Otan). (Souza, 1995, p.85)

Para Souza (1995), é possível haver no território juridicamente constituído e administrado pelo Estado uma sobreposição de outros territórios "dominados" por alguns grupos sociais, e que derivadas dessa sobreposição possam existir contradições entre as diversas territorialidades, por conta dos atritos existentes entre os poderes.

Desta forma, o autor necessariamente multiplica as possibilidades de entendimento acerca da relação Estado-poder-território, ao considerar outras formas de análise e não apenas a político-jurídica.

Por essa conceituação, o território não é visto apenas como espaço da ação do Estado. E o processo de territorialização pode ser conduzido por agentes sociais.

Ao ampliar a noção de território como substrato material de relações de poder, no qual o Estado é um agente importante, mas não o único, Souza (2009) permite-nos entender que

o exercício do poder, e com ele o desejo ou a necessidade de defender ou conquistar territórios, tem a ver com um acesso a recursos e riquezas, com a captura de posições estratégicas e/ou com a manutenção de modos de vida e do controle sobre símbolos materiais de uma identidade [...]. (Souza, 2009, p.64)

Apoiando-se na ideia de sobreposição de territórios, Mançano (2009) aponta que isso ocorre quando vários setores econômicos e sociais se utilizam do território para a consecução de seus interesses imediatos. Para ele, 
As instituições que formam o Estado-nação, como seus poderes, os partidos, os sindicatos, as igrejas, as fundações, as cooperativas, as empresas, os movimentos, as ONGs constroem espaços e territórios no interior do território do Estado, constituindo assim diferentes soberanias. (Mançano, 2009, p.202)

Até o início da década de 1930, os sindicatos tinham como regulação para a sua base territorial uma lei de 1907 a qual possibilitava inúmeras formas de organização territorial.

Essa viabilidade legal, como também a própria constituição dessas entidades, largamente baseadas nos pressupostos sindicalistas-revolucionários, de modo que o sindicato se organizava de forma autogestionária e federalista, primeiro localmente e depois formando uma entidade nacional, permitiu o surgimento de inúmeras estratégias territoriais.

Desta forma, foram comuns (para não dizer necessárias) as relações territoriais entre os sindicatos de matriz ideológica semelhantes, principalmente entre aqueles mais organizados (geralmente localizados nos grandes centros) e seus congêneres do interior do país.

Ou seja, a pluralidade sindical existente no país até o fim da década de 1920 permitiu a existência de uma territorialidade sindical baseada única e exclusivamente nas necessidades dos sindicatos.

Essas ações territoriais plurais não culminaram necessariamente em uma disputa por território entre o poder central (o Estado) e o movimento sindical. Entretanto, afirmamos a existência de uma territorialidade por serem essas ações sindicais baseadas em laços de afinidades, procurando construir uma rede solidária sindical, ao utilizarem-se de estratégias territoriais para a conquista de melhores resultados sociais para seus filiados.

A mesma estratégia territorial poderia não funcionar perfeitamente em todas as regiões do país e para todas as categorias de trabalhadores, surgindo assim uma enorme gama de ações territoriais, tanto local como nacionalmente.

Isso não significava, como veremos, um atomismo na maneira de se organizar, com as entidades, a todo momento, tentando formar uma 
rede sindical única. Essas estratégias territoriais seriam aos poucos minadas, seja pela maior ação estatal (principalmente a partir de 1931), seja pela própria divisão do movimento operário mais combativo, com a formação do Partido Comunista do Brasil (PCB), em 1922.

Isso porque as divergências ideológicas entre esses sindicatos demandariam uma clara separação e disputa pelas entidades de trabalhadores, possibilitando, com a intervenção do Estado nas relações entre capital e trabalho a partir de 1930, um enfraquecimento dessas lutas e consequentemente da presença de uma atuação mais estratégica no território.

Esse processo de centralização do poder fez que o Estado começasse também a delimitar geograficamente a ação sindical para que, segundo Oliveira Vianna (assessor jurídico do Ministério do Trabalho na década de 1930 e um dos principais ideólogos do Estado corporativo no Brasil), se atingisse um de seus objetivos

a eliminação do espírito de localismo, [e] a técnica adotada foi a da subordinação de todas as associações sindicais e de todas as instituições de direito social ao poder central - à autoridade federal. (Vianna, 1951, p.100)

Desta forma, internamente haveria uma centralização das ações territoriais dos sindicatos, restringindo uma maior aproximação entre as entidades de classe e, internacionalmente, seriam proibidas quaisquer possibilidades de relações. Para Oliveira Vianna o controle das relações internacionais dos sindicatos justificava-se pelos riscos de uma eventual aproximação sindical internacional. Pois

esta providência cautelatória - mantida, não apenas no texto da lei, mas na ação das autoridades administrativas incumbidas de executá-la - impediu a contaminação dos nossos grupos sindicais pelas ideias da III Internacional. (Vianna, 1951, p.100)

Ao intervir nos sindicatos, o Estado interferiu também nessas ações territoriais, determinando que essas territorialidades 
sindicais se desenvolvessem única e exclusivamente sob as suas determinações.

Entendemos, então, territorialidade como uma estratégia territorial, uma ação no território buscando um objetivo político/social ou econômico sem necessariamente que se consuma uma posse efetiva do território. Como afirma Haesbaert (2009),

Propomos, nesse caso, optar pela expressão "territorialidade" já que não se trata do território em seu sentido pleno, ou seja, onde a sua "materialização" se torna imprescindível. Embora todo território tenha uma territorialidade (tanto no sentido abstrato de "qualidade ou condição de ser território" quanto no de sua dimensão real-simbólica) nem toda territorialidade possui um território (no sentido de sua efetiva realização material). (Haesbaert, 2009, p.106)

A partir dessa análise, entendemos que o território não pode ser apreendido como área de atuação de um único agente (o Estado), pois outros organismos, como os sindicatos, também atuam e imprimem nele a sua marca.

Mais ainda, o conceito de territorialidade, compreendido enquanto ação territorial dos sindicatos na busca de uma maior organização, pode ajudar-nos a entender melhor as práticas dos sindicatos no território antes de 1930 e quais foram as consequências das intervenções estatais nessas ações territoriais, quando da chegada ao poder de Getúlio Vargas.

Muito embora historiadores e cientistas sociais, principalmente, tenham pesquisado acerca das potencialidades e dos limites deste movimento social urbano, poucos ${ }^{13}$ foram os que procuraram entender as territorialidades dos sindicatos no Estado liberal e quais mudanças essas territorialidades vão sofrer com o fim da pluralidade sindical.

13 Costa, S. (1986) pontuou minimamente alguns desses processos, embora não tivesse como principal objetivo analisar de que forma a ação estatal, a partir de 1930, restringiria as territorialidades dos sindicatos. 
Nesse sentido, faltam ainda pesquisas que possibilitem uma melhor compreensão das aç̃es dos sindicatos desse período. Desta forma, justificam-se trabalhos geográficos com o objetivo de entender as territorialidades sindicais, pouco usuais nos estudos sociológicos e históricos.

Para nós, esse trabalho possibilita uma diferente visão desse momento histórico, propiciando à Geografia, enquanto ciência, adentrar nesse terreno que até hoje foi pouco explorado por seus pesquisadores.

A ciência geográfica, por meio de sua ampla conceituação sobre território e territorialidade, nos revelou novas nuances desse processo, permitindo compreender a extensão dessa espacialidade sindical. 


\section{2 \\ O ESTADO LIBERAL E SUAS RELAÇÕES COM O MOVIMENTO OPERÁRIO NO BRASIL}

As análises sobre a relação entre o Estado e os sindicatos no Brasil do início do século XX, embora sejam fartas nas ciências sociais e na história, ainda são incipientes na geografia.

Este capítulo será marcado pela presença de uma análise de forte teor historiográfico, atendo-se aos fatos essenciais que marcaram a presença das ideias liberais no país, de que forma foram implementadas, suas principais características e, por fim, buscando compreender como o Estado atuou em relação a uma classe operária ainda em processo de organização, seja combatendo-a, por meio das ações policiais, ou regulamentando-a, por meio de uma legislação sindical.

Ao analisarmos as principais obras históricas e sociológicas sobre a constituição deste Estado liberal ${ }^{1}$ no Brasil, percebemos que, se havia no país algumas das liberdades defendidas pelos liberais, ${ }^{2}$ elas, concretamente, só eram usufruídas pelas elites que ocupavam os principais postos e não por todas as classes sociais.

Com relação à formação desse Estado liberal no Brasil, Vizentini (1983, p.8) aponta que a caracterização mais correta desse Estado seria a de um "liberalismo conservador e elitista", o qual tinha como

1 Para uma melhor compreensão das ideias liberais no Brasil, ver Viotti da Costa (1988) e Santos, W. (1978), entre outras obras sobre esse período.

2 Por exemplo, a defesa das liberdades individuais. 
principais bandeiras o federalismo, ${ }^{3}$ concedendo ampla autonomia estadual para a elaboração de constituições, o presidencialismo (em oposição ao parlamentarismo da fase monárquica) e a ampliação do regime representativo, com a inclusão de novos grupos anteriormente sem acesso ao sistema (não necessariamente as classes mais populares).

Ao ensejar uma prática liberal, mas dentro de uma lógica na qual, para algumas elites, como a paulista, sua defesa era mais pragmática do que ideológica, alguns autores, como Tristan Vargas (2004), refutam mesmo a presença do liberalismo no Estado predominante até o início da década de 1930.

Para ele, a validade de que no Brasil, no período que vai da proclamação da República até a Revolução de 1930, se instalou um Estado liberal é questionável em alguns aspectos. Isso porque, nesse período, foi comum a promulgação de várias leis municipais e algumas estaduais, buscando uma maior normatização nas relações entre o capital e o trabalho, principalmente em relação às categorias mais fortes do movimento operário, o que, de certa forma, desmentiria uma propalada prática liberal.

Em nossa opinião, em que pesem essas leis municipais, não havia ainda um claro direcionamento do Estado enquanto árbitro das relações entre o capital e o trabalho, prática comum a partir dos anos de 1930, quando da formação de um Estado corporativo.

Ao concordarmos com a historiografia que defende a presença de um Estado liberal no país, nas duas primeiras décadas do século XX, pretendemos demonstrar o que isso significou para o movimento

3 É importante esclarecer que o federalismo não está exclusivamente ligado às ideias liberais. Até mesmo escritores tão críticos ao liberalismo, como o economista e anarquista Proudhon, têm trabalhos acerca da concepção federalista de organização social. Entretanto, em vários momentos históricos (como na independência norte-americana), tanto as ideias liberais quanto o federalismo serviram de aporte ideológico. As análises de Bobbio (2004) sobre o federalismo e sua origem demonstram que, quando nos referimos ao federalismo estatal, tratamos de uma teoria baseada largamente nas concepções de Alexander Hamilton, pensador norte-americano que analisou e sustentou as teses federalistas encontradas na Constituição dos Estados Unidos de 1776. 
operário e, principalmente, para os sindicatos-revolucionários, no que diz respeito à sua ação territorial.

Desta forma, não procuramos discutir todas as nuances deste Estado, mas aquelas que de alguma maneira tiveram interferência, pontos de contato com a organização dos trabalhadores e que, posteriormente, foram suprimidas ou transformadas, como as questões do federalismo e da legislação sindical.

Acreditamos que entender alguns fundamentos ideológicos do Estado liberal pode nos ajudar a compreender também as práticas sindicais existentes nesse período e de que maneira as mudanças ocorridas com a chegada de Getúlio Vargas ao poder alteraram a forma de ser desse movimento sindical.

\section{1 - A emergência das ideias liberais e a crítica do movimento operário}

Oriundo em grande medida da luta da burguesia para diminuir o poder do monarca absoluto, o Estado liberal, desde o seu início, levando-se em consideração a Revolução Inglesa de 1689, (quando a aprovação do Bill of Rights assegurou a supremacia do parlamento sobre a realeza e permitiu o surgimento de uma monarquia constitucional), teve como sua linha mestra a separação dos poderes (Judiciário, Legislativo, Executivo) ${ }^{4}$ e a defesa das chamadas liberdades individuais. ${ }^{5}$

Um dos principais filósofos e defensores das ideias liberais foi John Locke. Partidário do jusnaturalismo, ${ }^{6}$ segundo ele, os homens

4 Ao comentar sobre as principais características do Estado liberal, Bonavides registra: "esteio sagrado do liberalismo foi, sem dúvida, o dogma da separação dos poderes" (Bonavides, 1980, p.35).

5 Entre elas, a liberdade de imprensa, a liberdade de culto e, principalmente, a livre-iniciativa.

6 Bobbio (2004) afirma que "o jusnaturalismo é uma doutrina segundo a qual existe e pode ser conhecido um 'direito natural', ou seja, um sistema de normas 
passaram, ao longo dos séculos, de um estado de natureza para um estado civil, no qual a existência do indivíduo é anterior à própria existência da sociedade e do Estado.

Para Locke, mesmo no estado natural a propriedade privada já existia, por se tratar de um fundamento anterior à própria sociedade e ao Estado, ou seja, a propriedade privada é um direito natural do indivíduo, e o Estado não pode violá-la.

Como aponta Mello (2004), um dos estudiosos do pensador inglês,

Locke afirma ser a existência do indivíduo anterior ao surgimento da sociedade e do Estado. Na sua concepção individualista, os homens viviam originalmente num estágio pré-social e pré-político, caracterizado pela mais perfeita liberdade e igualdade, denominado estado de natureza. [...] Nesse estado pacífico os homens já eram dotados de razão e desfrutavam da propriedade que, numa primeira acepção genérica utilizada por Locke, designava simultaneamente a vida, a liberdade e os bens como direitos naturais do ser humano. (Mello, 2004, p.84-85)

Para o liberal inglês, através do trabalho, o indivíduo conquistou o direito de ter a posse de bens imóveis e móveis (a começar pelo direito de dispor de seu próprio corpo) e, assim, a defesa da propriedade privada inscreve-se também na defesa da própria existência enquanto indivíduo.

Ao defender a propriedade privada, Locke argumentava que, embora a terra fosse um bem doado por Deus aos homens, o fato de eles conseguirem incorporar trabalho à terra nua possibilitava-lhes serem proprietários. Desta forma, para Locke, o trabalho era um dos pressupostos para a formação da propriedade privada.

Nessa defesa da propriedade privada está também o direito à liberdade individual, de modo que os homens somente por meio

de conduta intersubjetiva diverso do sistema constituído pelas normas fixadas pelo Estado (direito positivo)" (Bobbio, 2004, p.656). 
de um contrato social conseguiriam viver em sociedade. Em uma sociedade civil de caráter liberal, esses direitos, que ele considerava naturais, estariam preservados.

Com relação ao poder do Estado, Locke demonstrava que, ao passar de um estado da natureza para outro civil, a sociedade teria direito à escolha de seus governantes pelo voto da maioria, sendo que a minoria teria respeitadas as suas convicções.

Outras ideias importantes referem-se à separação dos poderes (com o poder legislativo, para ele o "poder supremo"; o poder executivo, subordinado ao legislativo; e o federativo, encarregado das relações internacionais) e à necessidade de formação de governos constitucionais, no qual a origem do indivíduo não fosse um critério de escolha para a ascensão ao poder.

A influência de Locke no pensamento liberal é incontestável. Mello (2004) aponta que as ideias de Locke foram de suma importância para a Revolução Americana e a Revolução Francesa. No caso norte-americano, foi por meio dessas ideias que os colonos nortistas, em defesa do direito natural e do direito de resistência (quando o governo não cumpre seu papel de defender as liberdades individuais e a propriedade privada, a derrubada do regime passa a ser algo necessário), conseguiram se libertar do sistema colonial britânico e contemplaram esses princípios na declaração de independência. No caso da Revolução Francesa, suas ideias foram influentes em Montesquieu e em Voltaire, estando, de alguma forma, presentes na Declaração de Direitos do Homem e do Cidadão. ${ }^{7}$

Além de Locke, outro autor importante no pensamento liberal dos séculos XVIII e XIX foi Adam Smith. Tal qual Locke, o economista escocês defendia as liberdades individuais e a propriedade privada. $\mathrm{O}$ interessante é que Smith entendia que esses direitos se

7 O $2^{\circ}$ artigo da Declaração dos Direitos do Homem e do Cidadão diz que "a finalidade de toda associação política é a conservação dos direitos naturais e imprescritíveis do homem. Esses direitos são a liberdade, a propriedade, a segurança, a resistência à opressão". Mais detalhes, ver: <htttp://www.archives. gov./exhibits/charters/charters.html>. Acesso em: 20/2/2011. 
concretizariam, de alguma forma, na presença da livre iniciativa e na livre concorrência. Ao sustentar essas proposições, defendia que, conforme a livre concorrência fosse o único sistema de controle econômico, os preços se ajustariam naturalmente pela dinâmica da oferta e da procura, o que ele chamava de "mão invisível".

Ao defender a livre-iniciativa como substrato da sociedade liberal, Smith compreendia que, quando todos individualmente fossem ao mercado e buscassem os seus próprios interesses, a economia criaria um mecanismo tal de autorregulação em que todos sairiam ganhando. Como mostrou Foucault (2008) na sua análise sobre o liberalismo, se o preço estiver

alto demais, os agricultores não hesitarão em semear tanto quanto puderem, pois, justamente, o preço está bom e eles esperam bons ganhos. Se semearem muito, as colheitas serão melhores. Quanto melhores forem as colheitas, menor é claro, será a tentação de acumular o cereal, agravando o momento de escassez. Logo, todo o cereal será comercializado. (Foucault, 2008, p.462)

Intervindo nessa dinâmica considerada natural ${ }^{8}$ por Smith, o Estado promoveria enormes prejuízos, já que desmantelaria esse equilíbrio de preços. Ou seja, a presença do Estado na economia deveria ser no máximo regulatória.

8 Um dos autores que discutem a passagem de um Estado no qual as leis têm grande papel concertador na ordem econômica (presente fortemente nos séculos XVI e XVII) para outro no qual o mercado deveria ser regulado não mais por leis externas, mas por leis "naturais" (dominante a partir de meados do século XVIII), é Foucault. Para o filósofo francês, nessa passagem, há uma naturalização das ações econômicas, ou seja, a economia deve funcionar "naturalmente", sem nenhuma pressão externa. "Assim, por exemplo, explicarão os economistas, é uma lei da natureza, a de que a população se desloca para os salários mais elevados; é uma lei da natureza a de que uma tarifa aduaneira protetora dos altos preços dos meios de subsistência acarreta fatalmente algo como a escassez alimentar" (Foucault, 2008, p.22). Ou seja, a intervenção estatal gera uma anomalia no curso normal da economia. 
Defendendo essas proposições de Smith, Von Misses (1985), um dos mais comentados liberais do século XX, apontava que a presença estatal seria deletéria aos mecanismos de mercado, pois

se um preço mais baixo for decretado pelo governo, o produto ficará abaixo dos custos e por conseguinte, os comerciantes e fabricantes reterão seu produto fora do mercado, na esperança de tempos mais favoráveis, talvez na expectativa de que seja eliminada a ordem governamental. (Von Misses, 1985, p.77)

Para Smith, essa dinâmica, de certa forma egoísta, é que faria o mercado funcionar naturalmente. Para tanto, uma de suas célebres frases afirmava que "It is not from the benevolence of the butcher, the brewer, or the baker that we expect our dinner, but from their regard to their own interest."

Outro fator importante na obra de Smith é a defesa da divisão do trabalho. Para ele, essa divisão do trabalho ocorre naturalmente, fruto das próprias necessidades humanas. Argumentando favoravelmente, Smith (2008) aponta que

This division of labour, from which so many advantages are derived, is not originally the effect of any human wisdom [...] It is necessary, though very slow and gradual consequence of a certain propensity in human nature which has in view no such extensive utility; the propensity to truck, barter, and exchange one thing for another. (Smith, 2008, p.14) $)^{10}$

9 "Não é da benevolência do padeiro, açougueiro ou do cervejeiro que sai o nosso jantar, mas do empenho deles em promover seu próprio interesse" (trad. livre).

10 "Essa divisão do trabalho, dos quais muitas vantagens são derivadas, não é um efeito de qualquer habilidade humana [...] Ela é a necessária, porém muito lenta e gradual, consequência, que certa predileção humana tem em intercambiar, permutar ou trocar uma coisa por outra" (trad. livre). 
Da mesma forma que, para Locke, a defesa da propriedade privada e a dos direitos individuais se pautava na defesa de direitos ditos "naturais", para Smith havia uma inevitabilidade do mercado na existência humana, pela própria propensão dos indivíduos em trocarem coisas.

Desta forma, tanto para Smith como para Locke, a defesa do liberalismo ia além da defesa de uma ideologia per si. Significava a defesa de uma sociedade "natural", pautada nos direitos naturais dos seres humanos. Esses direitos seriam conservados se a sociedade defendesse a liberdade individual, enquanto possibilidade dos indivíduos de disporem de seu trabalho livremente, sem que alguma forma de corporativismo surgisse e levasse à formação de uma concorrência desleal.

Isso porque, ao defenderem o individualismo, os liberais entendiam que qualquer ação coletiva na sociedade traria enormes malefícios para a competitividade entre os indivíduos, pois a função primordial dessa sociedade seria a de promover a "proeminência moral do indivíduo em relação aos desejos de qualquer coletividade social" (Stewart Jr., 1988, p.14).

Sendo assim, de acordo com essa concepção, a presença de sindicatos desde o início da proeminência liberal é um obstáculo à liberdade individual e, por isso, deve ser combatida pelo Estado, seja judicialmente ou por meio das investiduras policiais. Desta forma, ao advogar a autonomia individual, a ideologia liberal, por meio do Estado, restringiria a formação de agrupamentos organizados de trabalhadores que lutassem por seus direitos. E, ao combater essas organizações, procurava a prevalência do individual sobre o social. Como demonstra Stewart Jr. (1988),

As massas [...] não buscam a reflexão crítica; simplesmente seguem suas próprias emoções. Acreditam na teoria da exploração porque ela lhes convém, lhes agrada, não importando que seja falsa. Acreditariam nela mesmo que sua fundamentação fosse ainda pior do que é. (Stewart Jr., 1988, p.22) 
Ou seja, para a ideologia liberal, o Estado tem a função de manter na sociedade alguns princípios "naturais" dos seres humanos, como faz ser a lógica individualista,

Porque sustenta a proeminência moral do indivíduo em relação ao desejo de qualquer coletividade social; igualitária, na medida em que confere a todos os homens o mesmo status moral, não admitindo que existam diferenças de natureza política ou legal entre os seres humanos; universalista, por afirmar a homogeneidade moral do gênero humano e atribuir uma importância secundária a certos aspectos históricos e culturais; e meliorista, por considerar a possibilidade de correção e aperfeiçoamento das instituições sociais e políticas. (Stewart Jr., 1988, p.14)

Ao proporem essa forma de interpretar a sociedade, os liberais se contrapõem também a quaisquer possibilidades de grandes intervenções estatais, compreendidas como ações antiliberais e que trariam mais malefícios do que benefícios. ${ }^{11}$ Como decorrência lógica dessa forma de pensar, o uso da força policial é plenamente desejável e comumente utilizada a serviço dessa chamada liberdade contra os movimentos sociais.

Baseados nos princípios do laissez-faire e no laissez-passer, os liberais sempre entenderam que a economia, ao funcionar sem qualquer intervenção externa, possibilitaria uma melhoria do bem-estar de todos.Para Von Misses (1985), as fórmulas econômicas de intervenções estatais não conseguiram trazer uma melhor condição de existência para a humanidade. Diz: "Historicamente, o liberalismo foi o primeiro movimento político que almejou a promoção e o bem- estar de todos, e não de grupos especiais" (Von Misses, 1985, p.9)

11 Diz um dos partidários do liberalismo sobre isso: "A sociedade não pode passar sem o aparato do Estado, mas todo o progresso da humanidade teve de ser alcançado contra a resistência e a oposição do Estado e seu poder de coerção. Não é de surpreender que todos aqueles que tenham tido algo de novo a oferecer à humanidade nada tivessem de bom a dizer do Estado e suas leis!" (Von Misses, 1985, p.59) 
Ao proporem regras sociais baseadas na competitividade e no individualismo, os liberais afirmam que a humanidade deu um grande salto de qualidade e que seria errôneo associar suas ideias a uma classe específica.

Stewart Jr (1988) não se intimidava em dizer que

As vantagens de natureza prática e os fundamentos de natureza teórica justificam que se proponha a adoção da doutrina liberal na organização da sociedade, esta proposta se torna irrecusável se considerarmos a sua enorme preocupação de natureza ética. A ética sempre ocupou um lugar central no Liberalismo, desde os seus princípios. (Stewart, 1988, p.15)

Sendo assim, o Estado agiria apenas em casos de extrema necessidade, urgência, como forma de garantir a permanência dos principais pressupostos liberais, como a defesa da propriedade, "manter o ambiente institucional e o respeito às regras de modo a que possam florescer os talentos e as capacidades individuais" (Stewart Jr., 1988, p.77).

Essa sociedade "harmônica" permitiria o avanço inexorável da humanidade, transportando, ano após ano, milhares de pessoas para uma condição melhor numa progressão contínua na qual os mais aptos, com mais méritos, prosperariam e aqueles menos capazes teriam uma evolução inferior. ${ }^{12}$

Ao refutarem as teses intervencionistas, os liberais do século XVIII apontam os equívocos que tais ações trariam à sociedade, uma vez que muitas delas poderiam ocasionar grandes períodos de escassez alimentar. Um dos principais alvos das críticas era o

12 Para Stewart Jr.: "Embora mais tarde o liberalismo viesse a ser considerado uma 'exploração dos mais pobres', as grandes beneficiárias de seu advento foram as massas. Seu principal galardão é ter possibilitado um crescimento populacional sem precedentes na história da humanidade, acompanhado de um aumento via expectativa de vida e no conforto material" (Stewart Jr., 1988, p.20-21). 
sistema mercantilista, hegemônico em vários países da Europa até pelo menos o século XVIII.

O mercantilismo tinha como principais características a acumulação monetária pelo Estado (intervenção estatal na economia), manter o crescimento populacional como forma de fortalecer o Estado e, por fim, manter uma balança comercial favorável à metrópole, ao custo de explorar e manter um pacto comercial sempre desfavorável às colônias ultramarinas. Para os liberais, essa intervenção estatal na economia, longe de promover o bem-estar geral, estaria ligada aos interesses de um pequeno estrato da sociedade. Como forma de ampliar esse bem-estar à maioria da população, advogavam a necessidade de se manter a economia sem intervenção do Estado.

O mercado era apresentado como um elo da sociedade, o mais justo dos justos. Buscando o entendimento do funcionamento da sociedade inglesa, Smith concluía que o que unia as pessoas com tantos interesses diversos num único agrupamento social era o mercado. Como demonstra Heilbroner (1996, p.53) sobre as expectativas de Smith com relação ao mercado,

Dois grandes problemas absorvem a atenção de Adam Smith. Primeiro, ele está interessado em pôr a nu o mecanismo pelo qual a sociedade se mantém unida. Como é possível para uma comunidade na qual todos estão ocupadíssimos atendendo aos seus próprios interesses não escapar da força centrífuga? [...] Sem uma autoridade central planejadora e sem a influência constante das antigas tradições, como uma sociedade pode conseguir realizar as tarefas que são indispensáveis para a sobrevivência? Essas indagações levaram Smith à formulação das leis do mercado. O que ele pretendia era a "mão invisível", como a chamava, por meio da qual "os interesses e paixões particulares dos homens" são orientados na direção "mais benéfica para o interesse da sociedade inteira".

Prevaleceria o equilíbrio no local onde os indivíduos livremente fariam as suas trocas. Por isso, qualquer intervenção, mínima que fosse, segundo um dos seus defensores, "desorganiza a produção, 
diminui a satisfação" (Stewart Jr., 1988, p.47). É nessa esfera econômica que os mais capazes almejariam melhores vantagens, lucros e, por consequência, amealhariam mais riquezas.

Interferir nessa dinâmica "natural" geraria apenas desordem, anarquia (no sentido negativo da palavra), e favoreceria não os verdadeiros merecedores, mas os menos capazes. E era assim que Smith e os liberais viam o mercantilismo, já que a proposta econômica principal passava necessariamente pela intervenção estatal, que geraria, para eles, enormes desequilíbrios econômicos.

O mercado aparece para os liberais como uma cooperação social entre estranhos, "permitindo assim que homens cujos valores e propósitos sejam diferentes possam cooperar entre si sem que haja necessidade de acordo quanto aos objetivos de cada um" (Stewart Jr., 1988, p.46).

Aos liberais é impossível imaginar a sociedade sem a presença de um mercado. E, mesmo se nessa esfera as diferenças sociais aparecerem, aumentarem, ele não pode ser suprimido, pelo

fato de a desigualdade da riqueza ser possível em nossa ordem social, simplesmente pelo fato de estimular a que todos produzam o máximo que possam, é que a humanidade hoje conta com toda a riqueza anual de que dispõe para o consumo. (Von Misses, 1985, p.39)

Portanto, Von Misses (1985) trata o individuo como alguém na busca por melhores condições de existência. E quando "todos" os indivíduos vão ao mercado, buscando sua satisfação pessoal, todos ganham. E quanto maior a competição, maior a compensação. Como afirma Stewart Jr (1988),

Quanto maior a liberdade de entrada, maior a competição e, como consequência, maior a correspondente redução dos preços e dos lucros. Se a competição for limitada apenas às fronteiras nacionais, seus efeitos serão benéficos, se for ampliada para prevalecer entre um grupo de países seus efeitos serão melhores ainda, se for estendida a todo o planeta, seus efeitos serão o máximo que o homem 
pode almejar nas condições vigentes de conhecimento tecnológico e de disponibilidade dele. (Stewart Jr, 1988, p.52)

Outro liberal, Milton Friedman (1985), ao analisar as propostas econômicas do século XX, não hesita em demonstrar o que ocorre se não existir o mercado: as pessoas serão dominadas por um Estado totalitário. Diz:

Fundamentalmente, só há dois meios de coordenar as atividades econômicas de milhões. Um é a direção central utilizando a coerção - a técnica do exército e do Estado totalitário moderno. O outro é a cooperação voluntária dos indivíduos - a técnica do mercado. (Friedman, 1985, p.21)

Interessante perceber que o mercado até o século XVIII funcionava de maneira completamente diferente. Um dos estudiosos que se preocupou em analisar criticamente a emergência do mercado de tipo liberal foi o filósofo Michel Foucault. Embora mais conhecido pelas suas considerações sobre as várias esferas do poder na sociedade moderna, também procurou compreender a passagem de uma sociedade na qual o Estado tinha grande intervenção na economia para outra na qual a presença estatal era rejeitada.

Ao fazer algumas análises sobre o liberalismo, Foucault (2008) demonstra como o mercado transforma-se de um lugar justo, com clara interferência externa na composição dos preços das mercadorias ali comercializadas, em um mercado liberal presente em nossa sociedade a partir do final do século XVIII. Diz:

O mercado era um lugar de justiça a tal ponto que devia ser um lugar privilegiado da justiça distributiva, já que, como vocês sabem, para pelo menos certo número de produtos fundamentais, como os produtos alimentícios, as regras do mercado faziam que se chegasse a um arranjo para que, se não os mais pobres, pelo menos alguns dos mais pobres pudessem comprar coisas, assim como os mais ricos. 
E completa:

Esse sistema - regulamentação, justo preço, sanção da fraude fazia portanto que o mercado fosse essencialmente, funcionasse realmente como um lugar de justiça, um lugar que devia aparecer na troca e se formular nos preços algo que era a justiça. Digamos que o mercado era um local de jurisdição. (Foucault, 2008, p.42-43)

Por essas análises, transparece que o mercado tinha outra dinâmica, não era um local no qual as pessoas faziam necessariamente trocas desiguais. Mais ainda, é essa lógica do mercado que lentamente produz um Estado não intervencionista, e quanto menos intervencionista, mais justo ele seria.

O mercado é que vai fazer que o bom governo já não seja somente um governo justo. O mercado é que vai fazer que o governo agora, para poder ser um bom governo, funcione na base da verdade. (Foucault, 2008, p.45) ${ }^{13}$

Promover as chamadas liberdade econômica e a liberdade política: eis os objetivos principais dos liberais. Formar uma sociedade individualizada de cooperação voluntária: sua finalidade. Eis o mito do indivíduo cooperando voluntariamente por meio do mercado.

Logo, o Estado absolutista, existente até meados do século XVIII em vários países europeus, não se enquadrava nesses postulados liberais. Estes partem para um duplo ataque: exigir menor intervenção do Estado na economia e o fim do monopólio do poder nas mãos da nobreza.

Com a chegada da burguesia ao poder, essa ideologia passa a ser a oficial e as propostas postuladas por seus economistas e políticos

13 Foucault diz que essa "verdade" significa a partir de então deixar o mercado funcionar "naturalmente". Quanto mais "natural” o mercado funcionar, melhor será o governo. Ou seja, a economia dita as regras do funcionamento do Estado e não o contrário, comumente aceito até o século XVII. 
se naturalizam. Como forma de reduzir o poder da nobreza, impõese a separação do poder estatal em três instâncias: a Executiva, a Legislativa e a Judiciária.

Segundo essa lógica, a separação do poder estatal possibilita a formação de um Estado mais democrático, no qual todas as classes sociais (e não só a nobreza) teriam seus diretos individuais reconhecidos. Como afirma Bonavides (1980, p.7), com a burguesia no poder, o mote principal dessa nova sociedade era a passagem "do governo de uma classe ao governo de todas as classes".

Defender o sistema liberal nos século XVIII e XIX era de alguma forma ser partidário da separação dos poderes (Executivo, Legislativo e Judiciário), de um Estado no qual o parlamento tivesse a função de fiscalizar o poder central, como também a presença de representantes eleitos pelo povo (Friedman, 1985).

E as esferas política e econômica da sociedade estariam intrinsecamente ligadas, pois, como aponta Friedman (1985, p.17), "de um lado, a liberdade entendida em sentido amplo e, portanto, um fim em si própria. Em segundo lugar, a liberdade econômica é também um instrumento indispensável para a obtenção da 'liberdade' política”.

Ou seja, só é possível a liberdade política se a liberdade econômica também ocorrer, e vice-versa.Quando ambas ocorrerem, todos os atores ganham, principalmente em se tratando de nações. ${ }^{14}$ Entretanto, se um dos postulados vigora e o outro não é defendido pelo poder estatal, vivemos uma contradição do sistema liberal. E isso já ocorreu algumas vezes, como na Rússia czarista, na Espanha

14 Interessante perceber que a ideia de Kant de uma orquestração mundial, descrita principalmente no seu texto sobre a paz eterna (A paz perpétua), demonstra a necessária formação de uma federação de países europeus, como forma de permitir o progresso ininterrupto de todos. Mas essa orquestração plurinacional se desenvolveria apenas quando os países chegassem a esse equilíbrio econômico e político, e isso só seria permitido com o liberalismo. Como afirma Foucault nessa análise do liberalismo e das proposições de Kant, "Quanto mais vasto o mercado externo, menos fronteiras e limites haverá, mais se terá nisso a paz perpétua" (Foucault, 2008, p.78). 
e na Itália fascistas, onde o sistema capitalista convivia com formas totalitárias de Estado.

Para Friedman (1981),

Mesmo na Rússia czarista era possível para alguns cidadãos, sob determinadas circunstâncias, mudar de emprego sem ter que solicitar permissão a uma autoridade política, porque o capitalismo e a existência da propriedade privada permitiam algum controle sobre o poder centralizado do Estado. (Friedman, 1981, p.19)

A ascensão do sistema capitalista liberal "naturalizou" uma nova forma de compreender a economia e a política, não mais centrada na figura do rei e sem ter o Estado como monopolizador da força e do mercado. Como diz Bonavides (1980)

antes o político (o poder do rei) tinha ascendência sobre o econômico (o feudo). Depois, dá-se o inverso: é o econômico (a burguesia, o industrialismo) que inicialmente controla e dirige o político (a democracia). (Bonavides, 1980, p.23)

O sistema no qual a chamada liberdade econômica caminha, lado a lado, com a liberdade política, transformou-se. Adquiriu novas formulações, mas ainda pressupõe, mesmo que ideologicamente, essas características iniciais. ${ }^{15}$

15 Milton Friedman, um dos defensores do ideário liberal no século XX, aponta ainda que timidamente algumas mudanças na postura liberal entre os séculos XIX e XX. Diz: "Zeloso da liberdade e, por isso mesmo, temeroso do poder centralizado, quer em mãos do governo ou particulares, o liberal do século XIX era favorável à descentralização política. Comprometido com a ação e confiando na beneficência do poder enquanto estiver nas mãos de um governo ostensivamente controlado pelo eleitorado, o liberal do século XX é favorável a governos centralizados. Ele decidirá qualquer questão a respeito onde deverá residir o poder -a favor do Estado em lugar da cidade, do governo federal em lugar do estadual e de uma organização mundial em lugar de um apelo nacional" (Friedman, 1985, p.21). 
Mas não basta em si mesmo, sobretudo quando precisa dar respostas mais urgentes à sociedade, como no combate ao desemprego, à fome ou as más condições de trabalho. A luta por uma sociedade mais livre e igualitária passa pelo ideário liberal, mas não pode ficar atrelada a esse pensamento, pois a defesa da liberdade (econômica e política) não significa necessariamente a construção de uma sociedade mais democrática.

Ao conquistar o poder perante a nobreza, a burguesia demonstrava que a luta por uma sociedade mais livre e mais justa tinha como primeiro ato a derrocada do antigo regime.E, para isto, contou com o apoio das classes mais pobres que tinham a esperança de que a liberdade prometida estaria vinculada à emergência de uma sociedade mais humanizada.

Em que pesem terem grande papel nessas mudanças, as classes mais pobres pouco foram contempladas e, de certa forma, sentiram-se traídas, pois seu auxílio por fim não significou grandes transformações sociais.

E aqueles que defendiam a liberdade, a igualdade de direitos, e que apoiavam propostas mais revolucionárias, com a conquista do poder, tornaram-se conservadores. ${ }^{16}$

Bonavides (1980), ao defender mudanças no ideário liberal, demonstrou que algumas ideias como a separação dos poderes continuam a existir numa sociedade pós-liberal, menos individualista. Diz:

O liberalismo de nossos dias como o liberalismo realmente democrático já não poderá ser, como vimos, o tradicional liberalismo da Revolução Francesa, mas este acrescido de todos os elementos

16 Mesmo assim, entre os que defendem o liberalismo nos últimos vinte anos, é difícil aceitar a alcunha de conservador. Friedman (1985, p.15), por exemplo, refuta-a, pois "na prática o termo conservadorismo acabou por designar um número tão grande de pontos de vista - e pontos de vista tão incompatíveis um com o outro - que, muito provavelmente, acabaremos por assistir ao nascimento de designações do tipo liberal - conservadorismo e aristocrático". 
de reforma e humanismo com que se enriquecem as conquistas doutrinárias do liberalismo. (Bonavides, 1980, p.33)

Desta forma, algumas críticas ao liberalismo não significam o abandono completo das suas principais ideias político-econômicas. Para outras, as mudanças são necessárias naquilo que ao liberalismo é mais caro: a defesa da liberdade. ${ }^{17}$

Outras mais ainda, como o marxismo e o anarquismo, tiveram grande impacto na organização da classe operária, funcionando como um eixo condutor ideológico. A luta por uma sociedade mais democrática, mas também igualitária, era uma das principais bandeiras do movimento operário. E enquanto os trabalhadores organizados em sindicatos fizeram diversos questionamentos à ordem liberal, receberam ferozes críticas daqueles que defendiam abertamente a política do laissez-faire e do laissez-passer.

Polanyi (1980), estudioso das grandes mudanças no mundo industrial das primeiras décadas do século XIX e ferrenho crítico do liberalismo, demonstra que, no processo de surgimento das primeiras associações de trabalhadores, vários governantes liberais se levantaram contra, argumentando que tal prática (a formação de corporações) afrontava a liberdade do contrato e o laissez-faire. Entretanto, quando necessário, também se utilizavam de práticas não liberais.

É altamente significativo que, tanto num como noutro caso, sólidos liberais, de Lloyd George e Theodore Roosevelt até Thurnam Arnold e Walter Lippman, subordinaram o laissez-faire à exigência de um mercado competitivo livre. Eles pressionaram por regula-

17 Com relação à crítica mais autoritária ao liberalismo no Brasil, temos, entre outras, a crítica de Miguel Reale. Para esse autor "a liberdade não é um poder, uma faculdade de querer e de agir, e sim a ausência de obstáculos externos. Todo homem, todo grupo tem um rumo preestabelecido, uma rota a seguir. Destarte o problema da garantia da liberdade consiste, para o Estado, em impedir que haja impedimentos aos movimentos naturais. Eis porque já se pode escrever com razão que o liberalismo é a sistematização, não do que o Estado deve fazer, mas do que o Estado não deve fazer" (Reale, 1935, p.20). 
mentações e restrições, por leis penais e compulsão, argumentando como faria qualquer "coletivista", que a liberdade de contrato estava sendo "abusada" por sindicatos ou corporações, qualquer que fosse o caso. (Polanyi, 1980, p.152) (18 $^{18}$

As ideias socialistas demonstravam a incapacidade do ideário liberal em resolver as várias questões do mundo do trabalho e, principalmente, já não acreditavam em pequenas alterações na ordem estabelecida. Algumas propostas evidenciam a divergência do pensamento socialista em relação aos pressupostos liberais. Isso porque ataca um dos pilares do pensamento liberal: a propriedade privada. Num primeiro momento, os socialistas, dito utópicos, questionavam a sociedade industrial, mas não vinculavam as mudanças necessárias à revolução violenta.

Esses pensadores, alguns industriais, como Robert Owen, tiveram algumas de suas ideias praticadas nas suas propriedades. Posteriormente, essas ideias seriam base para os primeiros movimentos de trabalhadores organizados, como o movimento cartista. ${ }^{19}$

Outros tiveram importante participação na formação do pensamento socialista moderno, como Saint-Simon e Fourier. ${ }^{20} \mathrm{Na}$ pri-

18 Vianna, L. (1976) comenta também no Brasil a recusa de empresários em aceitar a presença de sindicatos. Diz: "Demonstramos como os empresários se opuseram a isso [formação dos sindicatos], dado que sua forma de acumulação repousava na presença da ortodoxia, que só admitia o contratante individual para a celebração dos contratos de trabalho" (Vianna, L., 1976, p.2).

19 O movimento cartista surgiu na década de 1830 e tinha como principais bandeiras a maior participação dos operários na vida política inglesa. Exigia o sufrágio universal, o escrutínio secreto e uma renovação anual do parlamento. Embora tivesse relativa força no seu início (se utilizando de greves, boicotagens, manifestações), divergências internas fizeram que esse movimento, já no final da década de 1840, fosse quase inexpressivo entre o operariado inglês.

20 Saint-Simon (1760-1825) foi um socialista francês, defensor de uma sociedade dominada por cientistas e industriais, na qual a exploração do homem pelo homem seria substituída por uma administração coletiva. Charles Fourier (17721837) foi um socialista francês e, entre suas principais ideias, está a defesa das cooperativas de consumo e de produção (conhecidas como falanstérios), cujos 
meira metade do século XIX, outros pensadores socialistas surgiram, diferenciando-se dos utópicos por não acreditarem em reformas pontuais no sistema e abertamente pregando a luta de classes. Entre esses pensadores encontramos Proudhon, Bakunin, Marx e Engels. Embasados em teorias filosóficas modernas, Marx e Engels abraçam a crítica ao capitalismo já nos primeiros escritos. Dentre eles, temos o Manifesto do Partido Comunista, de 1847-1848.

Nesse manifesto, é patente a diferenciação com os outros socialistas, considerados como burgueses, utópicos etc. e a defesa intransigente da luta de classes como caminho para a ascensão de uma sociedade mais igualitária.

Além disso, propunham severas críticas à ordem liberal predominante nos países mais industrializados, como a Inglaterra, e exigiam, como forma de avançar as propostas socialistas, a expropriação da propriedade latifundiária, a centralização do crédito nas mãos do Estado, por meio de um banco nacional com capital do Estado, e o trabalho obrigatório para todos.

De certa forma, conforme a organização operária evoluía e se complexificava, questionavam a validade das ideias de liberdade, igualdade e fraternidade, tão cara aos liberais, mas pouco presentes efetivamente. Demonstraram que, na prática, pouco poderia ser aproveitado do ideário liberal e que a luta por melhores condições de trabalho e de vida passava também pelo questionamento a essa ordem.

Melhor, perceberam que não eram indivíduos isolados. Sofriam as mesmas mazelas, possuíam as mesmas esperanças, compunham a mesma classe e, por isso, antagonizavam com aqueles que estavam no poder. Para o movimento operário mais combativo, a defesa da liberdade individual não significava o puro individualismo liberal. Significa a busca por uma maior defesa de seus interesses enquanto grupo, pois a luta de todos traria benefícios também ao indivíduo. Para esse movimento de trabalhadores, formar sindicatos poderia ir

rendimentos seriam divididos entre o trabalho, o talento e o capital. Essas informações biográficas foram coletadas na Grande Enciclopédia Larousse Cultural. 
contra a lógica individualista predominante, mas era condição sine qua non para uma maior ampliação de direitos sociais. ${ }^{21}$

Como ideologias em conflito cerrado contra o liberalismo, o anarquismo e o marxismo traziam substâncias ideológicas para esses trabalhadores, até então individualizados pela lógica dominante. Divergentes entre si, anarquismo e marxismo seriam as principais ideias dentro do movimento operário organizado e, posteriormente, seriam de grande importância na construção dos sindicatos.

Com um apelo classista, essas organizações sindicais reagiam contra o despotismo fabril, a farsa liberal, e propunham uma nova sociedade baseada na liberdade e, principalmente, na igualdade econômica. Usavam de várias táticas para fazerem valer suas lutas, como a greve, a boicotagem, a sabotagem, chegando, no caso dos sindicatos-revolucionários, ${ }^{22}$ à formação de um campo teórico-prático no qual possuíssem

uma atitude (conjugando hostilidade ao presente e crença no futuro), uma técnica (a militância, preferencialmente espontânea, em lugar dos dirigentes burocratas), uma estratégia (greves sucessivas até a greve geral revolucionária) e uma esperança (o sindicato como embrião e modelo para a organização do mundo social vindouro). (Cânedo, 1991, p.22)

Ao conquistarem importância no cenário econômico, os sindicatos foram aos poucos reconhecidos como interlocutores preferenciais

21 Sobre a necessidade de formação dos sindicatos, Cânedo afirma que "seria muito difícil defender-se, individualmente, contra os riscos de trabalho que anteriormente não existiam. [...] As novas condições de trabalho da sociedade industrial criaram a necessidade de mecanismos de pressão para impedir que o capitalista tratasse isoladamente com cada operário, e assim conseguisse forçar a baixa de salários e o aumento excessivo da jornada de trabalho. O campo institucional criado com vistas à luta do proletariado para aumentar o valor de sua força de trabalho, e do capitalista para diminuí-la, é o sindicato" (Cânedo, 1991, p.7-8).

22 A discussão sobre as origens do sindicalismo revolucionário estão presentes no Capítulo 3. 
dos operários, "com direitos e deveres [...] se viu consolidada e transformada numa das organizações mais sólidas do sistema capitalista" (Cânedo, 1991, p.21). ${ }^{23}$

A organização dos trabalhadores em sindicatos se expandiria e seriam formados partidos políticos (muitos deles ainda atuantes na Europa, como o Partido Trabalhista inglês [Labour Party] e o Partido Social Democrata Alemão [SPD]), contribuindo também para que posteriormente os trabalhadores conquistassem o poder em vários países.

Se na prática tais propostas de maior igualdade social se concretizaram não cabe analisarmos aqui. Obviamente, para os liberais, os países que se guiaram pelas propostas socialistas faliram ou, se ainda existem, estão fadados ao fracasso. ${ }^{24}$ Desta forma, entendemos que o movimento operário é um importante interlocutor do Estado liberal, interlocutor de grande crítica. Isso porque demonstrava, na prática cotidiana, a farsa da defesa da liberdade, tão cara aos liberais.

Os princípios liberais de defesa de maior participação política e social da sociedade, tão importantes para a queda de regimes absolutistas, se mostraram ainda elitistas, pois a maior parte da população continuava alijada de qualquer participação efetiva na sociedade.

23 Para Vianna, L., ao organizar-se, a classe operária impõe uma nova forma de se entender a relação entre o capital e o trabalho, agora não mais mediatizada pelos indivíduos apenas, mas pela existência de uma esfera jurisdicional. "O direito do trabalho emerge como uma conquista da classe trabalhadora contra o pacto original do liberalismo, impondo limites legais - externos - ao homem apetitivo. É como lei de exceção, sublinha Marx, que as leis de proteção ao trabalho aparecem durante a primeira metade do século XIX, criando um ramo do direito ao largo das relações privadas, puramente mercantis” (Vianna, L., 1976, p.23).

24 Diz Von Misses (1985) sobre essas experiências: "O que o liberalismo afirma, repetimos, não é, de modo algum, que o capitalismo seja bom, quando considerado de um determinado ponto de vista. O que o liberalismo diz é simplesmente que, para a consecução dos objetivos que os homens têm em mente, somente o sistema capitalista se mostra adequado, e que toda a tentativa de se chegar a uma sociedade socialista, intervencionista, socialista agrária e sindicalista se revelará, necessariamente, mal-sucedida” (Von Misses, 1985, p.90). 
Aos sindicatos, primeiros agrupamentos de operários contrários à ordem social, era necessário questionar os princípios liberais e também - principalmente entre aqueles que professavam ideias anticapitalistas - demonstrar que os trabalhadores tinham, além da crítica, suas próprias concepções de organização social.

Daí a necessidade de relacionar as propostas socialistas como críticas à ordem liberal e compreendê-las dentro do contexto de nascimento dos organismos operários de defesa, como os sindicatos. Essas lutas foram inúmeras e, até hoje, têm papel importante nesse processo de questionamento. Nos dias atuais, defender as ideias liberais não significa almejar uma sociedade mais democrática.

As contradições apontadas anteriormente e, de alguma forma, aceitas por vários liberais, demonstram que pouco do ideário de defesa da liberdade continua vivo. As sociedades capitalistas se complexificaram. De um lado, nos países mais ricos, os movimentos de trabalhadores ao longo do século XX conquistaram maior autonomia e questionaram veementemente essa ordem liberal, exigindo mudanças na estrutura social e conquistando também maior participação na gestão pública. Do outro lado, as várias crises ocorridas no século XIX e século XX colocaram em xeque a validade de grande parte dos pressupostos liberais, como a mínima intervenção do Estado na economia.

Importante é perceber como se deu a constituição do ideário liberal, suas principais bandeiras, e de que forma a classe operária, ao se organizar em sindicatos, questionou a validade dessas propostas. A análise seguinte se propõe a entender como o ideário liberal chegou ao Brasil, foi apropriado e aplicado pelas elites, e suas atuações no que tange à organização dos sindicatos.

\section{2 - A influência do liberalismo e do federalismo nas elites brasileiras}

É certo que parte dos filhos da oligarquia agrária desde o século XVIII passou a estudar Direito em Portugal, e foi na Europa que to- 
maram contato com os escritos liberais, tais como os de Montesquieu, Locke, Voltaire, entre outros. Decerto também essas ideias chegam às terras tropicais e ganham outro significado, abandonando algumas de suas proposições. Como afirma Viotti da Costa (1998)

o liberalismo brasileiro, no entanto, só pode ser entendido como referência à realidade brasileira. Os liberais brasileiros importaram princípios e fórmulas políticas, mas as ajustaram às suas próprias necessidades. (Viotti da Costa, 1998, p.134)

Isso porque se usa a lógica liberal, quase que unicamente, no sentido de criticar a presença portuguesa no país, ou seja, o liberalismo como afirmação de libertação colonial.

Por serem grandes proprietários de terras, esses liberais brasileiros se utilizavam de uma prerrogativa básica: libertar-se de Portugal é emancipar-se dos entraves econômicos determinados pela metrópole e não trazer o "fogo" da liberdade para todos (o que contradizia toda a economia centralizada ainda no grande latifúndio e na escravidão). Por isso, no século XIX, há uma tensão a se resolver: "encontrar uma maneira de lidar com essa contradição (entre liberalismo, de um lado, e escravidão e patronagem, de outro) foi o maior desafio que os liberais brasileiros tiveram que enfrentar" (Viotti da Costa, 1998, p.136).

$\mathrm{Se}$, na Europa, a luta liberal se travava no enfrentamento com a monarquia absoluta, no Brasil os liberais do final do século XVIII se voltavam contra uma monarquia absoluta específica: a portuguesa. Não se tratava de abolir privilégios, emancipar cativos à mão de obra livre, promover maior participação política, livre expressão de ideias, mas sim de se contrapor à dominação portuguesa e aos entraves que tal processo gerava, ou seja, uma maior participação política e econômica dessas elites (contra as restrições comerciais determinadas pela metrópole).

De certa forma, para os liberais nacionais, a luta contra o Estado absolutista significava, na prática, lutar contra o sistema colonial. De fato, a presença portuguesa no país pouco a pouco não mais conseguiria justificar a sua atuação, a manutenção de seus privilégios 
(como no comércio), e não mais apaziguava os conflitantes interesses dos vários grupos existentes até então, pois oferecia resguardo apenas aos portugueses.

Para Viotti da Costa (1998),

Quando os proprietários de terras, o clero, os comerciantes e os funcionários até então comprometidos com o sistema colonial se antagonizaram com o sistema, os princípios liberais apareceram como justificativa teórica dos movimentos revolucionários em prol da emancipação política do país. (Viotti da Costa, 1998, p.138)

Essa interpretação do liberalismo denotava o pouco ou nulo comprometimento com a emancipação social, política ou econômica das classes mais populares, inclusive tentando negar a existência de escravos no país. Com a Independência, os liberais procuraram colocar na Carta Magna propostas que trouxessem maior equilíbrio entre os poderes e, obviamente, cerceasse pouco que fosse o poder do imperador.

Suas intenções foram repelidas, alguns foram exilados, e vingou na Constituição de 1824 uma maior centralização do poder ${ }^{25}$ na figura do imperador (por meio do poder Moderador ${ }^{26}$ ). Entrava em vigor um sistema de subordinação política no qual as províncias ficariam submetidas ao governo central e os municípios, ao poder do governo provincial.

No que tange ao processo eleitoral, ainda que ideologicamente ligado às ideias liberais, na prática era controlado por uma minoria,

25 Com essa centralização do poder, o governo central controlava as taxas de importação e exportação; a distribuição das terras desocupadas, os bancos, as estradas de ferro, as sociedades anônimas, autorizava o funcionamento de empresas locais e estrangeiras, entre outras coisas (Viotti da Costa, 1998).

26 Segundo Viotti da Costa (1998), o poder Moderador delegava ao imperador as prerrogativas de escolher ministros sem consultar o Parlamento; suspender, adiar ou dissolver a Câmara e convocar novas eleições; nomear membros do Conselho de Estado e escolher os senadores dentre uma lista de três candidatos que recebessem o maior número de votos. 
com uma participação de apenas $2 \%$ da população brasileira. Além disso, o Senado era vitalício, tendo alguns parlamentares mais de 40 anos de legislatura quando da proclamação da República em 1889 (Viotti da Costa, 1998).

Para se ter uma ideia, em números reais, nas eleições de 1836 , num total de 3 milhões de habitantes, menos de 6 mil pessoas tinham direito a votar. Percebemos, ao analisar o período regencial, que as grandes ideias liberais, por mais que estivessem no cerne do discurso de parte da elite agrária antes da independência do país, não se concretizaram quando essa mesma elite alçou ao poder, isso porque parte desses liberais abandonou o discurso, que ficou quase circunscrito aos movimentos revoltosos.

Segundo Viotti da Costa (1988), por meio de seus jornais, apenas aqueles mais radicais continuavam ainda a defender o federalismo, o sufrágio universal, a garantia de direitos individuais, a abolição do poder Moderador, entre outras propostas de caráter mais democrático. $\mathrm{O}$ fato é que, mesmo no período regencial, ainda que existissem dois partidos dominantes no cenário político - o liberal e o conservador -, na prática as divergências ideológicas não eram tão profundas quanto poderia parecer a um estudioso desatento.

Durante esse tempo, o temor aos radicais uniu cada vez mais os dois setores representantes da elite agrária, tornando suas prováveis diferenças algo totalmente irrelevante. Ao analisarmos o período anterior à proclamação da República, percebemos que as ideias liberais mais radicais não se consolidaram e aos poucos eram eliminadas do restrito convívio político, mantendo-se apenas entre os revoltosos, como os da Confederação do Equador, de 1824, e os da Revolução Praieira, 1848-185027 (Viotti da Costa, 1998).

27 Esses dois movimentos se enquadram nas revoltas provinciais que ocorreram nas primeiras décadas após a independência brasileira. Tinham como características a luta por emancipação política e, por consequência, se opunham à presença de um governo centralizador no país. Defendiam o sistema federalista e, no caso da Revolução Praieira, esta era a favor do sufrágio universal. Para Viotti da Costa (1998), a principal crítica do movimento conhecido como Confederação do Equador se relacionava ao "direito de o imperador promulgar uma Carta 
Isso demonstra que a defesa do liberalismo quase se explica exclusivamente pela defesa da independência e, consequentemente, na obtenção de novos privilégios para essa elite rural. Quando conquistava a maioria da Câmara ou do Senado, parte dos liberais se transformava em conservadores, e vice-versa, e a defesa do ideário liberal passou a ser algo ligado apenas a uma questão conjectural, quando um grupo alijado reclamava maior participação no poder monárquico.

Como aponta Viotti da Costa (1998)

Considerando que tanto liberais como conservadores eram porta-vozes dos grupos sociais bastante semelhantes, não é de surpreender que a filiação fosse geralmente mais uma questão de família e parentesco do que ideologia. Até as últimas décadas do Império, a luta política era pouco mais que uma luta pelo poder entre facções lideradas por famílias mais prestigiosas. (Viotti da Costa, 1998, p.163)

Na segunda metade do século XIX ocorre a fundação do Partido Republicano que, se pouco acrescentava ao debate da época, aparece com uma grande novidade: a conjunção das ideias liberais com as republicanas.Embora as ideias liberais já não tivessem a importância para o Partido Liberal, ${ }^{28}$ foram resgatadas pelos republicanos

Constitucional, usurpando os direitos do povo de expressar sua vontade soberana através dos seus representantes na Assembleia Constituinte”. E completa, apontando o caráter ideológico desse movimento: "A crítica de Frei Caneca é um exemplo da retórica liberal nesse período” (Viotti da Costa, 1998, p.145).

28 O Partido Liberal existiu entre 1836 e 1889, composto basicamente por membros da oligarquia agrária. Tinha como principais bandeiras a liberdade de imprensa, a liberdade religiosa, opunha-se ao recrutamento militar, apoiava uma maior descentralização política das províncias e dos municípios e era contrário à presença do poder Moderador. No que tange à escravidão, “com exceção de uns poucos indivíduos excêntricos, a elite brasileira não estava preparada para abolir a escravidão e tampouco percebia contradição alguma entre liberalismo e escravidão" (Viotti da Costa, p.137, 1998). 
e tiveram um papel na condução de uma política que levaria ao rompimento do sistema.

A defesa da República ocorre sobretudo entre as elites agrárias de São Paulo, já que não obtinham grande participação no cenário político monárquico (observando a média de representantes entre 1868 e 1889, verifica-se que a província de São Paulo contava com 9 deputados, ao passo que Pernambuco dispunha de 13, município da Corte e Rio de Janeiro, 12, Minas Gerais, 20 e Bahia, 14), além do que "a centralização político-administrativa do Império era vista como forte entrave ao seu progresso” (Ribas da Costa, 2006, p.43).

Esse grupo de fazendeiros de São Paulo desde o início da década de 1870 se organizava e lutava por mais autonomia econômica e política, e já não sustentava apenas teses liberais, mas sobretudo apregoava abertamente a queda da monarquia. ${ }^{29}$

Em conjunto com alguns ex-liberais, caso de Quintino Bocaiúva, um dos signatários do Manifesto de $1870,{ }^{30}$ exigia a

Independência recíproca das províncias, elevando-as à categoria de Estados próprios, inicialmente ligados pelo vínculo da mesma nacionalidade e da solidariedade dos grandes interesses da representação e da defesa exterior, é aquele que adotamos no nosso pro-

29 Como afirma Ribas da Costa (2006), os republicanos paulistas, compostos basicamente de proprietários de terras, "ao lutarem pela federação, pela autonomia política e administrativa das províncias, defendiam seus interesses econômicos que julgavam arranhados, quando não tolhidas, pela ordem imperial”. Desta forma, [essa classe] "não podia defender a abolição, pois se assim o fizesse, enfrentaria a rejeição dos fazendeiros escravocratas (dos quais precisavam aproximar-se), que dependiam desse braço em seus empreendimentos, vale destacar que, nesse momento, muitos republicanos eram também proprietários de escravos" (Ribas da Costa, 2006, p.46).

30 O Manifesto de 1870 foi uma crítica republicana ao centralismo vigente no regime imperial brasileiro. Defendia a maior autonomia das províncias (federalismo) e considerava a Monarquia uma anomalia na América, já que nesse continente havia apenas repúblicas. 
grama, como sendo o único capaz de manter a comunhão da família brasileira. (Silveira, 1978, p.48)

No mais, os republicanos defendiam as ideias liberais que menos comprometessem o seu status econômico. A defesa desses pressupostos não significaria a inclusão da maior parte dos brasileiros no caminho institucional. Pelo contrário, a principal razão da República era a luta da elite paulista por maior autonomia em relação ao governo centralizado imperial.

E, ao ganharem maior importância no cenário nacional, contribuem para a própria proclamação da República (1889), quando em nome dos valores democráticos emerge ao poder uma parte dos militares brasileiros em aliança com esses setores republicanos.

Dizer que com a chegada dos republicanos ao poder teríamos um Estado calcado no liberalismo não seria de total acurácia. $\mathrm{Na}$ verdade, é a partir da Constituição de 1891 que vários pressupostos são colocados na ordem do dia. ${ }^{31}$ Isso porque a defesa do federalismo no país é uma crítica direta à Constituição de 1824 que previa um sistema unitário, centralista, de alguma forma não condizente com as extensões territoriais do país, no qual a autonomia provincial era quase inexistente.

Diferentemente da Constituição de $1824,{ }^{32}$ a de 1891 foi fortemente influenciada pela norte-americana ${ }^{33}$ e, entre outras coisas,

31 Entre eles poderíamos citar a separação dos poderes (Legislativo, Judiciário e Executivo) e a separação entre o Estado e a Igreja.

32 A Constituição de 1824, nas palavras de Andrade (2003) tornava o país "um Estado unitário, apesar da extensão territorial do Brasil, em que as províncias seriam governadas por presidentes designados pelo poder central, presidentes muitas vezes oriundos de outras províncias, sem um mandato e sem ligações políticas ou sociais locais. Eram meros delegados do poder imperial" (Andrade, 2003, p.44).

33 Um dos traços fundamentais da constituição norte-americana é a defesa do federalismo, como forma de manter um Estado unitário no qual seus integrantes continuassem a ter grande autonomia. Como aponta Bobbio (2004), o princípio básico do federalismo estatal "é a pluralidade de centros de poder soberanos 
advogava a separação dos poderes, o fim do poder moderador (existente até o fim do Império), a instituição do regime presidencialista e a separação entre a Igreja e o Estado.

No que tange às eleições, na prática, pouco alterava o processo eleitoral dominante no Império. Essa Constituição permitia o voto para todos os brasileiros com mais de 21 anos, exceto mendigos, analfabetos, religiosos e militares, o que significava na prática (quando se excetuam analfabetos) que apenas $25 \%$ da população teriam direito ao voto.

Isso já delineia o caráter liberal que a República teria pelos próximos 40 anos, no qual a participação das classes mais populares no jogo político seria praticamente inexistente.

Como aponta Resende (2006),

embora a Constituição de 1891 amplie juridicamente a participação política pelo voto e pelo direito de associação e reunião, a realidade que se impõe é uma verdadeira negação da ideia de participação política. (Resende, 2006, p.102)

As elites paulistas, de grande maioria agrária, continuavam a se utilizar de um discurso liberal como forma de manter alguns privilégios existentes, não se pautando em profundas reformas políticas e econômicas que atingissem principalmente a maioria do povo brasileiro.

E, o discurso liberal, que poderia trazer alguns empecilhos para a conformação de seu poder no país (como uma maior ampliação dos direitos sociais), simplesmente não era levado em consideração, pois, como afirma Resende (2006),

coordenados entre eles, de um modo tal que ao governo federal, que tem competência sobre o inteiro território da federação, seja conferida uma quantidade mínima de poderes, indispensável para garantir a unidade política e econômica, e dos Estados federais, que têm competência cada um sobre o próprio território, sejam assinalados os demais poderes" (Bobbio, 2004, p.481). 
passado o momento inicial de esperança de expansão democrática, consolidou-se sobre a exclusão do envolvimento popular no governo. Consolidou-se sobre a vitória da ideologia liberal pré-democrática, reforçadora do poder oligárquico. (Resende, 2006, p.103)

Com relação à distribuição do poder, o discurso liberal presente na nova Constituição Federal demonstrava o fim da centralização política, na qual

o poder passou para os estados e, dos estados, para os municípios. Os estados eram suficientemente autônomos para contrair dívidas no exterior e cobrar impostos, mesmo aqueles relativos a trocas como outros estados da federação. (Santos, 1978, p.91)

Essa nova dinâmica de poder, baseada fortemente em princípios federativos, favorecia obviamente os estados economicamente mais fortes e que tinham também grandes transações mercantis com o estrangeiro, ${ }^{34}$ determinando, por exemplo, que São Paulo em 1919 representasse quase $50 \%$ de toda a exportação brasileira $(49,9 \%)$, dando-se que se transformava em "uma locomotiva puxando vinte vagões vazios" (Andrade, 1998, p.112).

Num certo sentido, a defesa do federalismo por parte das elites agrárias paulistas se condiciona não mais como uma questão ideológica, mas de manter plenamente as riquezas amealhadas pelo café no estado de origem. ${ }^{35}$ Essa opção se explica pela própria experiência

34 Dean (1971), analisando o mercado exportador de café nas últimas décadas do século XIX e primeiras décadas do século XX, aponta que em São Paulo a dinâmica de crescimento das plantações possibilita que se produzam "resultados espetaculares: os embarques de café de Santos, o porto de mar de São Paulo, mais do que dobraram a cada década que passou depois de 1870. Em 1892 Santos exportou 40 milhões de dólares de café; em 1912, suas exportações totalizavam 170 milhões" (Dean, 1971, p.10).

35 Como afirma Silveira (1978), é nítido que a defesa do federalismo no Brasil era uma questão pragmática das elites regionais, principalmente a paulista. "Nas discussões sobre o federalismo no Brasil, os clamores contra a centralização 
econômica no período monárquico, que trouxe um grande desequilíbrio, pois

a excessiva centralização, desprovendo as províncias de recursos para atender as suas necessidades mais preementes em termos de administração, constituiu um dos argumentos usados contra as instituições monárquicas. (Silveira, 1978, p.127)

O processo que levou a uma maior autonomia dos estados trouxe também enfraquecimento daqueles com menor pujança econômica, surgindo uma discrepância de recursos entre os estados da federação.

Graças ao pacto federativo surgido com a Constituição de 1891, estados como São Paulo e Minas Gerais conseguiram ter grande expansão econômica, pois era facultado ao estado ter o controle sobre as exportações, bem como era vedada a cobrança de impostos sobre o seu produto por estados fronteiriços. ${ }^{36}$

A questão da autonomia estadual era tão importante que a presença federal nos estados ocorreria em situações extremas, como invasão de países estrangeiros, de um estado no outro, desordens e descumprimento de leis federais, para citar as mais graves. A relação entre o poder central e os poderes estaduais teria uma pequena alte-

escondiam verdadeiramente clamores contra um Estado que açambarcava todas as esferas - econômicas, social, política, administrativa - da vida nacional, contrariando determinados interesses dos setores mais dinâmicos da sociedade desejosos de se expandir. A este convinha um Estado menos absorvente" (Silveira, 1978, p.59).

36 Como aponta Andrade (1998), "o sistema de distribuição da competência na coleta de tributos, dando aos estados o controle do imposto de exportação, permitia a São Paulo, o estado mais rico e principal produtor e exportador de café, uma expressiva receita que fez ele se distanciar dos demais estados da federação. Nos primeiros anos da República o Brasil era, sobretudo, exportador de café, beneficiando São Paulo e até certo ponto Minas Gerais, e de borracha, beneficiando o Amazonas e o Pará. [...] São Paulo acumulava recursos que permitiam a expansão de seus cafezais, a ampliação de sua rede ferroviária, a modernização do porto de Santos e o desenvolvimento industrial" (Andrade, 1998, p.108-109). 
ração (no que tange à questão federalista) com a chegada de Campos Sales à Presidência do Brasil em 1902 e a instituição da chamada "política dos governadores".

Como forma de diminuir a autonomia estadual e fortalecer a autoridade presidencial, Campo Sales procurou estruturar o poder federal de maneira que os governadores elegessem o presidente e este, por meio de sua influência, reconhecesse apenas os mandatos dos deputados simpáticos ao governo, tolerando uma minoria inexpressiva de oposicionistas.

Isso não significa, entretanto, que o federalismo tenha deixado de ser o principal mote institucional desse governo. É nítido que a opção pelo federalismo no Brasil se deu mais por uma questão pragmática das elites regionais, principalmente a paulista, do que a defesa de uma ideia per si.

A opção federalista, uma das bandeiras do ideal liberal, como o próprio liberalismo num todo, nunca foi no país instrumento de incorporação das classes mais populares, ou mesmo a defesa das várias liberdades individuais (de expressão, política, econômica).

A junção República-federalismo não necessariamente transformou o quadro socioeconômico predominante no Império: oligarquias regionais baseadas economicamente na exploração do latifúndio agroexportador. No que diz respeito à questão territorial, a República, imbuída de preceitos liberais, transformou as antigas províncias em estados, a antiga capital do Império em Distrito Federal, e manteve as fronteiras territoriais internas como no Império.

Para Silveira (1978), ao defenderem o binômio República-federalismo, os liberais, a partir de 1870, lutavam contra a centralização e

escondiam verdadeiramente clamores contra um Estado que açambarcava todas as esferas - econômica, social, política, administrativa - da vida nacional, contrariando determinados interesses dos setores mais dinâmicos da sociedade desejosos de se expandir. A estes convinha um Estado menos absorvente. República mais federação foi a fórmula encontrada para atender as finalidades propostas. (Silveira, 1978, p.59) 
Um fato curioso e que demonstra a pouca defesa ideológica por parte dos novos governantes republicanos foi a manutenção de leis imperiais antigas; assim, em vários estados da federação, o presidente era o mesmo que governava na época imperial. Isso ocorria, pois

o que existia, subjacente ao partidarismo republicano, em nível estadual e local, e que explica o seu vazio doutrinário, era um meio social interno aos estados, dispondo-se numa economia agrária, integrando as pessoas em uma estrutura familiar ou de parentesco onde o relacionamento se fazia ao nível pessoal. As combinações políticas eram feitas diretamente entre os chefes locais, numa graduação que se convergia no governo estadual. (Silveira, 1978, p.83)

O fato é que um forte questionamento a essa situação (predomínio do federalismo) só ocorre a partir de 1930 com a chegada de Getúlio Vargas ao poder, pondo fim à chamada "Velha República", culminando com a promulgação da Constituição de 1937, pela qual "os estados perderam toda a autonomia, passando a ser administrados por interventores nomeados pelo poder central e proibidos de terem escudos, bandeiras, hinos, o que era uma tradição republicana" (Andrade, 2003, p.59).

Uma das primeiras críticas feitas pelo governo surgido da Revolução de 1930 foi justamente questionar as propostas liberais existentes na Constituição de 1891.

Como aponta Fausto (2009),

As medidas centralizadoras do governo provisório surgiram desde cedo. Em novembro de 1930, ele assumiu não só o poder executivo como o legislativo, ao dissolver o congresso nacional, os legislativos estaduais e municipais. [...] Limitava também a área de ação dos Estados, que ficaram proibidos de contrair empréstimos externos sem a autorização do governo federal. (Fausto, 2009, p.333)

Antes mesmo de entrarmos nessa discussão, que para nós vai além de pontuar alguns fatos históricos, mas sim perceber a forma- 
ção de um Estado corporativo, veremos de que forma o movimento operário se organizava dentro de uma estrutura federalista e liberal. Ao analisarmos algumas particularidades do Estado liberal brasileiro percebemos que nunca ocorreu, mesmo que minimamente, a incorporação político-social ou econômica das camadas mais pobres da nossa sociedade.

Até aqui, vimos que as ideias liberais no Brasil, desde a sua emergência, em fins do século XVIII, foram apropriadas pela elite agrária com certo pragmatismo: usa-se o liberalismo na defesa da Independência (a luta contra Portugal e o acesso aos mercados internacionais) e na defesa da República (contra a centralização política do Império, como forma de favorecer a maior pujança econômica do estado de São Paulo).

O que fica evidente é o liberalismo brasileiro e suas variantes (como o federalismo) não fornecerem subsídios que buscassem grandes modificações na estrutura socioeconômica brasileira.Essa forma de compreender o liberalismo gerou certa dualidade nas ações do Estado em relação ao movimento operário: uma legislação sindical que possibilitaria certa autonomia, de um lado, e, de outro, uma ação policialesca que não permitia qualquer possibilidade de existência de grupos sindicais de caráter mais revolucionário.

É fato também que a primeira Constituição republicana (1891), ao possibilitar mudanças na forma de se governar (agora mais descentralizada), pouco trouxe em favor das demandas sociais existentes. Como demonstra Gomes (1994)

a Constituição reconhecia a autonomia política dos estados federados e sancionava uma atuação intervencionista muito limitada do governo federal. Efetivamente tratava-se de uma nítida opção pelo credo liberal, que desconhecia os direitos sociais (mesmo aqueles anteriormente aceitos) e restringia os direitos políticos àqueles que tivessem acesso privado à educação. (Gomes, 1994, p.40)

Entretanto, por pouco que fosse, o movimento organizado dos trabalhadores contribuía para que algumas reformas ocorressem 
e de, certa forma, esse Estado calcado no liberalismo teria que ceder. ${ }^{37}$

Assim,

O liberalismo oligárquico implantado com a Constituição de 1891, ao fechar, pelo rigor da lógica da sua carta de princípios, os caminhos da regulamentação do mercado de trabalho, deixa campo livre para a sociedade civil organizar e colocar uma nova legalidade. (Vianna, L., 1976, p.49)

Um fato interessante que ocorre no início do século XX é a implementação da primeira legislação sindical, o Decreto n.1637, de 5 de janeiro de 1907. ${ }^{38}$ Esse decreto teve como objetivo regulamentar a formação de sindicatos no país, muito embora "não se tinha em vista realmente a criação de um espírito sindicalista, de resistência profissional e de arregimentação de classe, e sim o de cooperação, de auxílio mútuo, de assistência" (Moraes Filho, 1952, p.186).

Uma característica desse decreto era a sua aproximação com o liberalismo, influenciado pela lei francesa de 1884, delegando às entidades de trabalhadores grande autonomia no que tange à or-

37 Uma das discussões ocorridas no final do século XIX no Senado Federal versava sobre a atuação do Estado nas relações entre o capital e o trabalho. Em 1896, defendendo essa isenção do Estado, o vice-presidente Manoel Vitorino afirmava que "intervir o Estado na formação dos contratos é restringir a liberdade dos contratantes, é ferir a liberdade e a atividade individual nas suas mais elevadas e constantes manifestações [...]. O papel do Estado nos regimes livres é assistir como simples espectador à formação dos contratos e só intervir para assegurar os efeitos e as consequências dos contratos livremente realizados" (apud Tristan Vargas, 2004, p.64).

38 A legislação sindical para Moraes Filho (1952) em nada alterava o liberalismo dominante nas relações entre o Estado e os sindicatos: "As relações entre o Estado e o sindicato deviam permanecer no campo do cordial respeito mútuo. Nada mais deveria providenciar aquele do que fixar os limites da organização profissional. Somente isso. Ficava a critério das respectivas classes todo o restante do seu autogoverno associativo sem a menor intervenção dos poderes públicos" (Moraes Filho, 1952, p.189-190) 
ganização interna e relações com outras entidades de trabalhadores do mesmo ofício ${ }^{39}$ No seu artigo $2^{\circ}$, por exemplo, era explícita a influência liberal, pois "os sindicatos profissionais constituem-se livremente, sem autorização do governo (apud Moraes Filho, 1952, p.187)", apenas sugerindo que as entidades de classe, como forma de estarem legalmente constituídas, depositassem em cartório três exemplares do estatuto, da ata da instalação e da lista normativa dos membros da diretoria.

Um artigo em especial, o $4^{\circ}$, de grande interesse ao nosso trabalho por se remeter à questão territorial dos sindicatos, afirmava categoricamente que "Os sindicatos terão a faculdade de se federar em uniões ou sindicatos centrais, sem limitação de circunscrições territoriais" (apud Moraes Filho, 1952, p.187), ou seja, ao sindicato era facultado, conforme as suas necessidades, a definição da base territorial.

Como veremos adiante, graças a essa determinação, mas também à própria dinâmica de organização dos sindicatos-revolucionários, várias entidades apresentavam extensa base territorial, tendo-se inclusive a formação de sindicatos com base territorial nacional. Ao possibilitar que o sindicato tivesse a preferência na definição da sua base territorial, o Estado propiciou que na mesma base existissem vários sindicatos de uma mesma categoria ou, em outras palavras, o decreto de 1907 permitia a pluralidade sindical.

Apesar de tal autonomia, na prática, os sindicatos eram constantemente alvo de ações policiais, como o fechamento de suas sedes, ou mesmo, o empastelamento ${ }^{40}$ de seus jornais. Sobre uma greve na cidade de Poços de Caldas em 1919, o jornal A Voz Operária comenta a entrada de policiais na sede da Liga local:

39 Ainda em 1903 foi promulgado o decreto 979, regulamentando os sindicatos rurais no país. Com isso, vários sindicatos urbanos, representando quase 6 mil trabalhadores, solicitaram ao deputado Inácio Tosta o envio de uma lei ao Congresso Nacional para regularizar os sindicatos profissionais. Mais detalhes em Moraes Filho (1952).

40 Expressão muito comum no início do século XX, segundo o Dicionário Houaiss significa: "Destruir as instalações de um jornal, revista etc. por motivos políticos ou pessoais". 
A Liga permaneceu no dia de sábado guardada pela polícia. Antes, porém, o delegado tinha ido aí com diversos praças. E como ao companheiro Vizotto disseram que a sede tinha sido assaltada, ele soltou diversos gritos de rebelião e estava disposto a tudo se não fosse a intervenção de sua família e de seus camaradas. (A Voz Operária, 7/9/1919, p.3)

Citando outros fatos, Evaristo de Moraes (1952) demonstra que

Por ocasião da chamada greve dos cocheiros - triste tentativa sem plano e sem chefes -, toda gente imparcial se sentiu indignada diante dos processos violentos do pessoal da polícia, que pôs a capital da República em estado de sítio, prendendo, ameaçando, coagindo por todas as formas [...]. A greve dos sapateiros durou meses, deu ocasião a várias intervenções policiais e não poucas prisões arbitrárias. (Moraes Filho, 1952, p.192)

É nesse sentido que afirmamos o duplo caráter do Estado liberal brasileiro no tratamento ao movimento operário, promovendo, de um lado, maior autonomia sindical e, de outro, coagindo as entidades de trabalhadores com ações policiais. Não é sem motivo que Vianna, L. (1976), ao comentar sobre o decreto de 1907, afirma que a promulgação ocorreu somente enquanto "proforma", já que a própria força do movimento operário demonstrada nas greves anteriores ao decreto (principalmente em 1906 e na greve geral de 1907, em São Paulo) já seria um motivador para a "legalização" dos sindicatos.

Nesse embate contra o movimento operário mais revolucionário é que se depreende a existência do artigo $8^{\circ}$ do decreto, pois abertamente indicava a necessidade dos sindicatos se constituírem "com o espírito de harmonia entre patrões e operários [...] destinados a dirimir as divergências e contestações entre o capital e o trabalho" (apud Moraes Filho, 1952, p.188). O já citado artigo $2^{\circ}$ demonstra essa intenção do governo em dificultar a existência desses sindicatos, quando afirma que "só podem fazer parte dos corpos de direção dos sindicatos, brasileiros natos ou naturalizados, com residência no país 
de mais de cinco anos", visto a maior parte dos sindicatos-revolucionários serem formados e/ou dirigidos por maioria de imigrantes. ${ }^{41}$

O fato é que o Estado liberal, ao legislar sobre os sindicatos existentes, de um lado, e de outro atacar sistematicamente as organizações mais revolucionárias, fará que o movimento operário, a partir de 1906, como diz Vianna (1976), "conservando o jargão, a inspiração e a estratégia anarquista, perceberá no Estado um interlocutor vulnerável a sua ação, reivindicando dele leis protetoras e regulamentadoras do trabalho" (Vianna, L., 1976, p.52).

E essa potência do movimento operário permite que o liberalismo estatal, predominante nas relações entre capital e trabalho, seja colocado em xeque, visto que

em meados do ano de 1917, está assinalado pelas grandes agitações do movimento operário, quer no Rio, quer em São Paulo [...] intrínseca relação com o surgimento de uma preocupação mais regular sobre a legislação social por parte dos meios políticos e empresariais. (Gomes, 1979, p.25)

A tônica do Estado liberal no Brasil no início do século XX seria a de favorecer a presença de sindicatos menos críticos ao Estado e ao capital, como forma inclusive, como vimos, de atenuar a presença dos sindicatos mais revolucionários. Não é de se estranhar que, em 1912, reuniu-se no Rio, sob auspícios do governo, quando era presidente da República o marechal Hermes e os então tenentes Mario Hermes [filho do presidente da República] e Palmiro Serra Pulquério [militar e construtor de vilas operárias no Rio de Janeiro], um Congresso Operário, chamado de $4^{\circ}$ Congresso Operário Brasileiro, realizado no Palácio Monroe, depois sede do Senado Federal.

41 Maram (1979), acerca dessa característica, comenta que "o fato diferencial entre trabalhadores imigrantes e trabalhadores brasileiros era, de um modo geral, que os primeiros ocupavam os cargos qualificados e semiqualificados, cargos esses de muito mais peso para a continuidade do sindicalismo. Esses homens constituíram o corpo de organizadores do movimento na década de 1890 e começo do século XX” (Maram, 1979, p.30). 
O $4^{\circ}$ Congresso Operário, ocorrido em 1912, foi organizado por sindicatos contrários à tendência revolucionária presente na Confederação Operária Brasileira (COB). Ao se autodenominarem como o “4”" congresso, segundo Rodrigues (1979, p.190), incluíam, como congressos operários anteriores, os estaduais de 1896 no Rio Grande do Sul e de 1907 em São Paulo, e o congresso nacional de 1906.

Numa de suas resoluções, a crítica aos sindicalistas-revolucionários ficava clara:

Considerando finalmente que o Brasil conta também diversas agremiações cooperativistas, cujo caráter é genuinamente proletário, porque visam exclusivamente à defesa dos interesses dos trabalhadores e à resistência ao capitalismo, e que estas sociedades quando não se guiam pelos princípios anarquistas e antiestatais são as mais idôneas para formarem o núcleo central da organização nacional do proletariado. (Congresso Operário de 1912, 1963, p.73)

Esse congresso também condenou a tática de ação direta e ainda desconsiderou o Estado como causador dos males de grande parte da classe operária, ao afirmar que "no estado de coisas presente, não é possível pretender do Estado a organização completa de um serviço de tal ordem que exigirá somas avultadíssimas" (Congresso Operário de 1912, 1963, p.79). Com relação à presença de entidades, neles estiveram associações do Rio de Janeiro, São Paulo, Belo Horizonte, Juiz de Fora, Porto Alegre, entre outras. ${ }^{42}$

Desta forma, percebemos que a defesa da liberdade e autonomia sindical ficava muito aquém do que a ideologia liberal supostamente proporia. Mais uma vez, a defesa de leis liberais no país se dava dentro de um contexto próprio: diminuir a influência sindicalista mais revolucionária nos meios operários nacionais. Ou seja, com o liberalismo, que como vimos anteriormente teria alguma importância na formação da República no país, as propostas defendidas a partir

42 Mais detalhes desse congresso, ver: Documentos do Movimento OperárioCongresso Operário de 1912 (Estudos Sociais, v.V, n.17, jun. 1963, p.69-87). 
desse momento de ruptura com a monarquia envolveriam também manobras que propiciariam a emergência de um liberalismo (para alguns grupos já existentes, como os sindicatos-revolucionários) sem uma definida liberdade na prática.

Graças a essa ação intimidatória do Estado com relação aos sindicatos-revolucionários, a crítica operária às leis que regiam esse Estado liberal era comum nas páginas dos jornais de sindicatos.

A nossa Constituição, quem não sabe, é um modelo de liberdade, e se as leis valessem algo, o Brasil seria, nesse sentido, o Éden do mundo: entretanto pega nos jornais de São Paulo de maio-junho do ano passado e verás: violação de domicílio, prisões injustas, proibição de reuniões, sequestro de manifestos, roubo de móveis e objetos que nos pertenciam. (A Luta Proletária, 1908, apud Toledo, 2009, p.306)

O significado do liberalismo no país não pode ser avaliado sem levar em consideração a presença de uma elite agrária de cunho conservador, que não tinha nenhuma preocupação em se utilizar desses pressupostos para a emancipação de grande parte da população brasileira.

Quando os trabalhadores se organizavam e declaradamente se opunham ao modelo dirigente dominante, as ideias liberais que permitiriam na teoria a possibilidade de organização desse movimento urbano eram sumariamente esquecidas e, na prática, os operários mais combativos eram atacados, presos e não raramente mortos nos porões das prisões. ${ }^{43}$

A legislação social que ganharia alguma relevância a partir de 1918 (graças principalmente às greves de 1917 em São Paulo) seria

43 Tristan Vargas (2004, p.28) aponta que, já no início da República, antes mesmo do surgimento de uma legislação que de alguma forma normatizasse o sindicalismo brasileiro, o Código Penal já arbitrava sobre a existência de greves, estabelecendo "prisão celular por 1 a 3 meses" para quem "causar ou provocar cessação ou suspensão de trabalho por meio de ameaça ou violência, para impor aos operários ou patrões aumento ou diminuição de serviço ou salário-penas". 
alvo de debates entre os parlamentares brasileiros, pois, para alguns destes, era importante que o federalismo fosse respeitado. Porém, ao respeitarem esse preceito, não ficava claro para essas autoridades qual legislação (municipal, estadual ou federal) poderia arbitrar sobre as relações entre o capital e o trabalho. ${ }^{44}$

O período que se inicia em 1918-1919 e se estende até 1930 não teria grandes transformações no que tange à regulamentação dos sindicatos, ou seja, a lei promulgada em 1907 continuaria regendo esse período, o que tornava os sindicatos autônomos com relação a uma maior intervenção estatal. ${ }^{45}$

As mudanças mais estruturais da década de 1920 estariam ligadas às ações de alguns parlamentares no Congresso, com a intenção de legislar sobre o trabalho, demonstrando assim o início de uma tendência que a partir de 1930 se tornaria dominante: a ação externa nas relações entre o capital e o trabalho. ${ }^{46}$

Isso significa que os sindicatos não teriam nenhuma interferência externa que resultasse em transformação na ação territorial predominante até a década de 1920. Comentando sobre a continuidade

44 Sobre a legislação social surgida a partir da segunda metade da década de 1910, Tristan Vargas (2004) demonstra que "uma iniciativa do Congresso Nacional no sentido de regulamentação feriria a Constituição, perturbando a vida autônoma dos Estados e desvirtuando a essência do próprio regime federativo". E conclui o autor: "Essa divisão de competência entre União e poderes locais seria própria do regime federativo" (Tristan Vargas, 2004, p.54).

45 Para Gomes (1979), “o período que vai desde 1907 a 1919 é caracterizado como uma etapa do movimento operário, pois o mercado de trabalho está sob a sua influência (os sindicatos são livres e autônomos) e fora do campo de intervenção do Estado”. E completa o raciocínio: “De 1919 a 1930, portanto o restante da República Velha, os sindicatos permaneceriam atuando, mas o mercado de trabalho começara a sofrer a ação regulatória do Estado" (Gomes, 1979, p.58).

46 Vianna (1976, p.61-62) aponta algumas leis trabalhistas surgindo nesse período, como consequência das pressões trabalhistas ocorridas em 1917. Dentre elas poderíamos citar a Lei Elói Chaves, que instituía a caixa de aposentadoria dos ferroviários, e a Lei n¹6027, de 30 de abril de 1923, que instituía o Conselho Nacional do Trabalho. 
das ações territoriais dos sindicatos na década de 1920, Simão (1966) apontava que

A simultaneidade de tipos de associação profissional bem como de suas formas federativas persistiu até o primeiro quinquênio de 1930, apesar das mudanças que então se tentaram promover no sindicalismo. (Simão, 1966, p.179)

A possibilidade de relações territoriais entre os sindicatos, ligadas aos laços federativos entre as entidades, permaneceu durante toda a década de 1920 e parte da década de 1930. Em que pese essa maior presença externa nas relações entre patrões e operários, para Vianna, L. (1976) "no Brasil, até meados dos anos 1920, tínhamos um Estado liberal não intervencionista que deixava o mercado entregue às suas leis próprias" (Vianna, L., 1976, p.72).

Para Munakata (1984), essa predominância de uma prática liberal até nas relações entre o Estado e o movimento operário ocorria também porque o movimento operário sindicalista-revolucionário era avesso à ingerência estatal nas relações com o patronato, pois advogavam ideologias antiestatais, como o anarquismo e assim "a relação de trabalho é um assunto privado, impermeável à ação do Estado e que deve ser resolvido pelo confronto seguido da negociação direta, do contrato” (Munakata, 1984, p.17).

As reais mudanças que incidiram sobre as ações territoriais dos sindicatos ocorreram somente a partir do início da década de 1930, quando a legislação sindical liberal foi substituída por outra de características corporativistas. O Estado liberal brasileiro, organizado sob a égide do federalismo republicano, como destacamos anteriormente, se mostrou incapaz de se relacionar com as classes produtivas urbanas organizadas em sindicatos, sobretudo aquelas que declaradamente se mostravam contrárias a qualquer interferência externa.

O modelo que emergiu na proclamação da República no Brasil mostrou-se também incapaz de mediar os conflitos correntes entre o capital e o trabalho e, quando tal mediação ocorreu, era nítida a opção em combater os sindicatos-revolucionários, cooptar os sin- 
dicatos conservadores e, inexoravelmente, apoiar as diretrizes dos industriais.

A defesa do liberalismo no país, no início do século XX, pouco contribuiu para a inserção das camadas populares no sistema econômico vigente. Mesmo arredios a qualquer interferência externa, os sindicatos-revolucionários contribuíram para que alguma legislação social fosse gestada pelos governantes do período.

O medo de uma revolução social nos moldes daquelas ocorridas na Rússia em 1917, aliado aos intensos questionamentos da ordem social aqui no país entre os anos de 1917 e 1919, funcionou como um desencadeador para as mudanças que surgiriam, ainda tímidas, na década de 1920 (como a legislação trabalhista), mas que se tornariam basilares do governo "revolucionário" da década de 1930.

Este capítulo mostrou-nos o dual sentido do liberalismo: a defesa das liberdades individuais e econômicas e o combate às massas proletárias no mundo capitalista. Esse dilema esteve presente no país, com o agravante de que aqui, em terras tropicais, o liberalismo teve que se adequar a uma elite recém-saída de um modelo econômico escravocrata.Posteriormente, esta obra discutirá a emergência de um outro modelo de relação entre o Estado e a classe operária: o modelo corporativista.

Ao discutirmos ambos, temos em mente, principalmente, apontar as diferenças de tratamento em relação à classe operária, mas também quais mudanças o modelo corporativo acarretou na forma de ser dos sindicatos, no que se refere a sua organização territorial.

Nas próximas páginas, a perspectiva da relação entre o Estado liberal e a classe operária estará acentuada pela visão dos trabalhadores, quando perceberemos de que maneira os sindicatos-revolucionários atuavam perante a presença de uma legislação sindical liberal. 


\section{3 \\ A AÇÃO TERRITORIAL DOS SINDICATOS-REVOLUCIONÁRIOS SOB O ESTADO LIBERAL}

Os estudos sobre o movimento operário que têm como foco as ações territoriais ainda são escassos. Poucas foram as pesquisas que procuraram compreender essas ações e de que maneira os sindicatos as organizavam. Desta forma, os estudos sobre o operariado e sua relação com o território são insuficientes e sujeitos a grandes desafios, muito embora a nossa pesquisa tenha demonstrado a viabilidade dessa discussão na Geografia, ao utilizarmos dois conceitos-chave dessa ciência, território e territorialidade, ambos com a intenção de melhor compreender as ações dos sindicatos.

Ao aceitarmos esse desafio, procuramos demonstrar de que forma a análise geográfica contribuiria com os estudos sobre o sindicalismo brasileiro do início do século XX, proporcionando uma compreensão melhor sobre as intensas movimentações (seja na organização de greves, manifestações públicas, encontros nacionais) que as entidades sindicais realizavam como forma de conquistarem melhores salários e condições de trabalho.

Desta forma, discutir o movimento sindical organizado tendo como base os referenciais geográficos significa também entender as estratégias territoriais utilizadas por esses sindicatos. Neste capítulo teremos como objetivo demonstrar a emergência do movimento sindical no mundo e no Brasil, atentando-nos, principalmente, ao que tange ao sindicalismo-revolucionário. 
Além disso, analisaremos a sua atuação tendo em evidência as políticas administradas para a classe operária pelo Estado liberal dominante até o fim da década de 1920, já discutido no capítulo anterior. Nas próximas páginas, nossas preocupações voltam-se a compreender minimamente quais eram as principais correntes sindicais existentes no início do século XX no país, suas bandeiras de luta e os métodos de ações.

\section{1 - O movimento sindical no início do século $X X$ no Brasil}

A pluralidade de ideias e ações no movimento sindical do início do século XX no Brasil é patente. Grande parte delas, oriunda dos imigrantes europeus que aqui aportaram, funcionou enquanto sustentação ideológica de vários sindicatos. ${ }^{1}$

Antes mesmo da criação de sindicatos de resistência, os trabalhadores procuraram alguns mecanismos de solidariedade para atenuar a difícil vida que levavam. Dentre essas opções, as entidades mutuais/beneficentes, reformistas e as católicas, funcionaram enquanto possibilidade de organização dos trabalhadores. De forma geral, essas entidades sindicais buscavam respeitar as implicações legais existentes, produzindo muito pouco no que tange a uma ação sindical mais contundente e que suplantasse esses marcos regulatórios.

Além da análise dessas entidades, teremos como foco, prioritariamente, as organizações sindicais baseadas no sindicalismo-revolucionário, pois eram as que claramente definiam-se como classistas e empreendiam uma luta direta contra o capital. Mais ainda, ao definirem a luta de classes como uma tática para a conquista de melhores condições de vida e de transformação social, realizavam várias práticas territoriais de grande importância para nossa pesquisa.

1 Em sua maior parte, esses imigrantes, não conquistando o tão sonhado acesso à propriedade rural, tornaram-se anarquistas e socialistas. 
É importante frisar que a nossa escolha em aprofundar a discussão acerca dos sindicatos-revolucionários explica-se também pela supremacia dessas organizações até a década de 1930, largamente destacada por Batalha (2000) e Antunes (1982). Desta forma, neste capítulo nossas atenções voltam-se ao entendimento das territorialidades dos sindicatos-revolucionários, como também à compreensão da participação das outras tendências existentes no período, aquelas de perfil mais conservador - casos das mutuais/beneficentes, reformistas e católicas -, ou também as de caráter revolucionário, caso da presença do Partido Comunista nos meios sindicais.

Entendemos que esta análise propiciará, quem sabe, um melhor entendimento acerca da diversidade ideológica que existia entre os sindicatos nesse período, momento esse marcado por grande agitação operária.

\subsubsection{As associações mutuais e beneficentes no sindicalismo brasileiro}

Ao escolher discutir as entidades beneficentes/mutuais, reformistas e católicas, propomos apresentar de que forma essas entidades se organizavam e suas relações com o Estado, afirmando que nossa análise se baseará unicamente na bibliografia existente, e não em fontes primárias (uma vez que não é o escopo principal desta obra).

Organizando-se, num primeiro momento, em entidades beneficentes e étnicas, o operário buscava formas de mitigar uma vida repleta de penúria econômica, recorrendo a essas associações que funcionavam como um polo de ajuda mútua. Uma questão inicial é entender que esse operariado do início do século XX era composto predominantemente de imigrantes europeus, vindos com suas famílias, subvencionados pelo Estado, e dispostos a se estabelecerem definitivamente no país.

Isso não significa que entre os primeiros operários não existissem fortes núcleos de trabalhadores nacionais, como foi demonstrado 
por Batalha (2000), apontando que a visão majoritária de que os operários eram imigrantes possibilita o desaparecimento "sobretudo dos negros, além disso, de resto, o Brasil inexiste ao norte do Rio de Janeiro" (Batalha, 2000, p.7).

Sem necessariamente serem ideologicamente homogêneas, essas agremiações

viam a necessidade de organizações duradouras, fortes e financeiramente sólidas para alcançar seus objetivos, não hesitando em manter funções mutualistas para garantir a permanência dos associados pagando suas mensalidades. Para esse sindicalismo a greve era o último recurso, e nada mais que isso, jamais um fim em si mesmo, pois o que importava era a obtenção de ganhos, mesmo que parciais, em qualquer momento. (Batalha, 2000, p.33)

Essas associações mutuais/beneficentes não possuíam como método de ação o enfrentamento de classes, nem pontuavam a necessidade de se colocar a vida cotidiana numa perspectiva de uma mudança radical. As entidades sindicais de caráter mutual/beneficente surgem ainda no século XIX entre trabalhadores de diversos ofícios e empregos públicos.

$\mathrm{Na}$ verdade, a constituição de uma associação de tendência mutual, por exemplo, ocorria largamente entre aqueles grupos de trabalhadores que já mantinham algum nível de qualificação ou mesmo de uma tradição organizacional maior (Batalha, 2000). Essas entidades propunham-se a realizar programas assistenciais que incluíam serviços-farmacêuticos e auxílio em caso de enfermidades, desemprego, invalidez e funerais.

Eram combatidas pelos sindicatos-revolucionários, já que pregavam, de certo modo, uma resignação dos trabalhadores com relação a sua situação de penúria, sendo por isso, contrárias à luta de classes. Para os militantes sindicalistas-revolucionários, essas organizações criavam a falsa expectativa nos operários de que pudessem conseguir melhoria nas suas condições de existência sem afetar as relações de produção. Além disso, reforçando a origem étnica, por exemplo, 
dividiam a classe operária, enfraquecendo o movimento de cunho reivindicatório.

Ao se organizarem dessa forma, essas associações não propunham grandes transformações na vida operária (ou seja, um mundo socialista e sem exploração nem era cogitado) e por isso recebiam grandes ataques de anarquistas, muito embora estes também se utilizassem de ações que buscassem a cooperação operária, como no caso de uma greve de grande magnitude, na qual a solidariedade econômica, por exemplo, possibilitava uma maior continuidade do movimento.

Essas sociedades mutuais/beneficentes tinham diferentes formas de organização interna, sendo que algumas especificavam a necessidade de seus associados terem ligação étnica ou funcional para a admissão em seus quadros, enquanto outras não mantinham qualquer restrição (Simão, 1966).

Essas entidades estavam organizadas localmente, ligadas aos interesses corporativos de cada profissão, podendo ser étnicas, religiosas etc., não demonstrando assim uma ideologia dominante.

Conforme a luta operária ia tornando-se mais complexa, visto que os antagonismos de classe ficam cada vez mais claros entre os operários e os patrões, essas agremiações iam perdendo espaço para as entidades mais combativas, como as sindicalistas-revolucionárias e posteriormente as comunistas.

Apesar de algumas delas tentarem a formação de união geral de associações mutuais, Simão (1966, p.161) aponta somente a existência de uma federação de associações, no ano de 1899, em São Paulo.

\subsubsection{Os sindicatos reformistas e sua atuação sindical}

Os sindicatos denominados reformistas (Batalha, 2000) não possuíam necessariamente uma coesão ideológica e, assim, não representavam uma unidade dentro do movimento sindical do início do século XX. Ao serem chamadas posteriormente de reformistas, essas entidades sindicais, aos olhos desatentos do leitor, parecem possuir propostas e formas de ação equivalentes. 
Entretanto, a formação dessas correntes já nos mostra a dificuldade de enquadrá-las numa única concepção ideológica, visto a presença de socialistas, positivistas e corporativistas, para citar as principais tendências. Para Batalha (2000), o que as unia de certa forma era a busca por melhorias na vida operária, mesmo que parciais, possibilitadas com o acesso constante às autoridades enquanto mediadoras de conflitos.

Além disso, incentivavam a participação política de alguns militantes nas eleições legislativas, num processo no qual as conquistas operárias poderiam ser consolidadas através de leis.

No decorrer de sua existência, os sindicatos reformistas sempre tentaram rivalizar com os sindicatos-revolucionários na arregimentação da classe operária, seja por meio da criação dos partidos operários e operários socialistas (Fausto, 1976), ou mesmo na organização de um encontro nacional operário, chamado de $4^{\circ}$ Congresso Operário de 1912, realizado na cidade do Rio de Janeiro, com o apoio explícito do governo federal.

Apesar de ideologicamente terem divergências entre si, a maior discordância se dava em relação aos sindicatos-revolucionários, principalmente no que tange à participação em eleições, à aproximação com as autoridades públicas, e ao fato de não terem a greve como um recurso prioritário de defesa de classe.

Muito embora seus métodos de ação fossem diferentes, algumas bandeiras defendidas nesse $4^{\circ}$ congresso operário se assemelhavam àquelas historicamente defendidas pelos sindicatos-revolucionários, como "oito horas de trabalho, limitação do trabalho de mulheres e menores, descanso semanal, indenização por acidentes, pagamentos por semana" (Fausto, 1976, p.56).

Esses sindicatos, em sua quase totalidade, encontravam-se na cidade do Rio de Janeiro, antigo Distrito Federal, com pequena presença dessas entidades no Rio Grande do Sul, Minas Gerais e Pernambuco. Quando houve o $4^{\circ}$ Congresso Operário de 1912, entidades de várias partes do país participaram do evento, o que denota a nós, numa primeira impressão, um maior espraiamento desses sindicatos pelo país. 
Entretanto, embora demonstrando uma maior presença nacional, ao contrário dos encontros organizados pelos sindicalistas-revolucionários, não se pode afirmar que ele comportasse uma linha ideológica e de ação comuns a todos os participantes, pois como apontou Batalha (2000) "o sindicalismo reformista nunca foi ideologicamente homogêneo e jamais alcançou uma unidade organizacional, como ocorreu no sindicalismo revolucionário com a COB" (Batalha, 2000, p.32).

Em 1923, surgiu novamente uma tentativa de organização de uma parte desses sindicatos, agrupando-se os cooperativistas numa única entidade nacional, a Confederação Sindicalista Cooperativista Brasileira (CSCB), ${ }^{2}$ que atuou junto ao nascente Partido Comunista (surgido em 1922), com a proposta de, nas palavras de Batalha (2000, p.36), "reduzir a influência dos anarquistas nos sindicatos e tomarlhes o controle dessas organizações".

Mesmo com essa tentativa de reorganização de parte dos sindicatos reformistas por meio da CSCB, a sua abrangência territorial não ia além do antigo Distrito Federal, do sul de Minas Gerais e do leste de São Paulo. Batalha (2000) não titubeia em dizer que "essa corrente não representaria mais do que uma nota de rodapé na história do movimento operário brasileiro, não fosse a aliança que constituiu com o nascente Partido Comunista"3 (Batalha, 2000, p.27).

Em linhas gerais, os sindicatos reformistas, em que pese terem grande participação na organização dos trabalhadores do início do

2 A Confederação Sindicalista Cooperativista Brasileira (CSCB) foi fundada em 1921 e extinta em 1924. Teve em seus quadros 74 associações profissionais e cooperativas, substituindo a outrora associação de base local Federação Sindicalista Cooperativista Brasileira (Batalha, 2009, p.225).

3 Gomes (1988) discute as principais bandeiras defendidas pela CSCB e suas diferenças com o sindicalismo-revolucionário. Para a autora, embora os cooperativistas da CSCB “reconhecessem a greve como um 'sagrado direito proletário', propunham que a conquista de máquinas, oficinas e fábricas fosse feita por meio de uma sistematização cooperativista, destinada a transformar o capital singular em capital coletivo. Rejeitavam, por conseguinte, a ação direta e opressora, que atuava pela desapropriação violenta de todas as riquezas, declarando inimigos Estados e patrões” (Gomes, 1988, p.132). 
século XX na cidade do Rio de Janeiro, não conseguiram amealhar grande destaque entre a maioria operária, principalmente entre os imigrantes, visto que esses operários tinham pouco interesse em participar na política partidária brasileira nos termos propostos por esses sindicatos. Na década de 1930, já em outros moldes, muitas das ideias centrais dessas agremiações (como a intermediação do Estado no conflito capital e trabalho) estariam em evidência após a chegada ao poder de Getúlio Vargas. ${ }^{4}$

\subsubsection{Os sindicatos católicos e a questão social}

Outra vertente da organização sindical nas primeiras décadas do século XX era a católica. Tinha como objetivo subtrair o operariado da influência anarquista e socialista. Ao contrário dos sindicatos reformistas, que não possuíam uma composição ideológica uniforme, os sindicatos católicos sabiam claramente qual modelo organizacional seguir: a doutrina social da Igreja Católica, expressa na encíclica Rerum Novarum de 1891. ${ }^{5}$ Formadas por leigos, essas entidades

4 Sobre a postura tomada pelos sindicatos reformistas com relação à política sindical estatal, Araújo (1994) diz que no pós-1930: "foram essas correntes reformistas, receptivas à ação do Estado, que do interior do movimento operário deram vida imediata ao projeto sindical do Governo Provisório. Os amarelos procuraram oficializar imediatamente os sindicatos sob o seu controle e pelo menos uma parte deles associou-se ao Ministério do Trabalho tanto na realização de uma campanha de sindicalização e na organização dos setores operários sem experiência sindical anterior, quanto no combate aos sindicatos autônomos" (Araújo, 1994, p.194-195).

5 A Encíclica, com um cunho conservador, defendia a existência da propriedade privada, criticava veementemente o socialismo, apontando como algo "prejudicial àqueles membros que a querem socorrer, contrários aos direitos naturais dos indivíduos, desnaturando as funções do Estado e perturbando a tranquilidade pública". Com relação às greves, a Encíclica afirmava que "é preciso que o Estado ponha cobro a esta desordem grave e frequente, porque estas greves causam dano não só aos patrões e aos mesmos operários, mas também ao comércio e aos interesses comuns [...]". Mais detalhes: <http://www.vatican.va/holy_father/ 
estiveram presentes em várias localidades do mundo, rivalizando, em muitos lugares, com os socialistas e os sindicalistas-revolucionários no que tange à organização da classe operária. As principais características desse sindicalismo eram a "defesa do catolicismo, do entendimento entre trabalhadores e patrões e contrários às greves, mescladas a uma tímida denúncia dos males da industrialização e um virulento antissocialismo" (Batalha, 2000, p.28).

No Brasil, até o final da década de 1920, tiveram uma presença territorial diminuta se comparada com os sindicalistas reformistas e revolucionários, sendo encontradas em São Paulo, Minas Gerais e Pernambuco, sendo que no Rio de Janeiro sua influência aumentou como resposta às grandes agitações operárias de 1917-1920 (Batalha, 2000, p.28). ${ }^{6}$

A partir de 1930, esses sindicatos ganhariam maior expressividade, e é sob pressão de várias de suas organizações, como o Centro Operário Católico metropolitano, que em 1934 se interrompe um período de unicidade sindical (1931-1934) e volta-se à pluralidade sindical. ${ }^{7}$

É importante frisar que, a partir de 1935, quando a ação estatal no controle dos sindicatos torna-se mais forte, esses sindicatos lentamente vão se extinguindo, prevalecendo, a partir desse momento, os sindicatos oficiais. ${ }^{8}$

leo_xiii/encyclicals/documents/hf_l-xiii_enc_15051891_rerum_po.html>. Acesso em: 12/5/2011.

6 Em Minas Gerais, por exemplo, os sindicatos católicos formaram em 1919 uma Confederação Católica do Trabalho, baseada na Encíclica Rerum Novarum, e com o objetivo de educar o operário na fé católica, bem como implantar o ensino religioso nas escolas públicas.

7 Embora a pluralidade voltasse ao cenário sindical, cada categoria somente teria direito apenas a três representantes por base territorial. Na verdade, o sindicalismo católico desde os primeiros momentos da intervenção estatal aceita a postura do governo, realizando, ainda em 1931, atos de apoio a Lindolfo Collor, então Ministro do Trabalho. Mais detalhes, ver Antunes (1982).

8 Consideramos sindicatos oficias aquelas entidades surgidas com a intervenção estatal ou que aceitando esse processo, procuraram ser reconhecidas pelo Estado. Mais detalhes, ver o Capítulo 5, principalmente o subcapítulo 5.2. 


\subsubsection{Os sindicatos-revolucionários e os sindicatos comunistas: teoria e prática sindical de combate}

Saindo do campo conservador do meio sindical, temos os sindicatos-revolucionários e os sindicatos apoiados pelo Partido Comunista. As primeiras organizações sindicais revolucionárias, e que claramente se diferenciavam das entidades conservadoras, apareceram no cenário mundial em meados do século XIX, com a formação dos primeiros sindicatos por ofício que deram origem às organizações internacionais de trabalhadores.

No momento em que o operariado percebeu que somente a sua organização enquanto classe reduziria as mazelas sociais existentes, diversas entidades surgiram no mundo industrial. Entre elas, poderíamos citar a Grand National Consolidated Trades, em 1834, na Inglaterra, uma das primeiras federações de sindicatos nacionais, até chegarmos à principal entidade mundial de trabalhadores do século XIX, a Associação Internacional de Trabalhadores (AIT) fundada em 28 de setembro de 1864, em Londres, a partir do contato entre trabalhadores franceses (participantes, a convite do seu governo, da Exposição Industrial Mundial de Londres) e o Conselho Sindical de Londres, entidade representativa do movimento operário inglês.

Além de trabalhadores franceses e ingleses, a AIT congregou no seu início vários grupos de emigrantes, como italianos e alemães. Representando os alemães e fazendo parte de seu Conselho Geral estava Karl Marx, redator dos estatutos da entidade. No decorrer da década de 1870, a AIT ganhou maior importância entre os trabalhadores e muitas de suas diretrizes foram seguidas em várias organizações operárias, tanto na Europa, através de entidades belgas, suíças, holandesas, italianas, espanholas e austríacas, como na longínqua América do Sul, onde se instalaram seções na Argentina e no Uruguai, estas últimas incentivadas por Eliseé Reclus. ${ }^{9}$

9 Sobre a importância de Reclus na organização da Primeira Internacional na América do Sul, ver Hardman (1982). 
Embora despertando ódio entre a burguesia e a igreja, ${ }^{10}$ a importância da AIT para a classe operária não esmorecia. Pelo contrário, já nos seus primeiros congressos, como o de Londres em 1865, e principalmente em Genebra em 1866, é nítido, entre os debates, a necessidade de reconhecimento do movimento sindicalista e de sua arma mais importante: a greve.

Nesses primeiros congressos, as principais divergências no que tange à organização dos trabalhadores estavam entre Marx, seus apoiadores, e os proudhonianos. Isso ocorria porque, para Marx, a luta operária deveria ocorrer simultaneamente à luta revolucionária e, desta forma, as conquistas parciais dos trabalhadores na luta contra o capital (como a exigência de medidas sociopolíticas por parte do Estado a favor de mulheres e crianças ou em prol da limitação da jornada de trabalho) não trariam empecilhos à revolução.

Contrariamente, os proudhonianos, liderados por Tolain, negavam qualquer interferência do Estado em matéria de regulamentação das condições contratuais de trabalho porque achavam que isso estabilizava o Estado e colocava em perigo a liberdade social. Essas divergências se estenderam e ampliaram-se no Congresso de Lausanne, em 1867. O ponto central dos debates na cidade suíça foi a discórdia entre Marx, que preconizava a necessidade de organização dos trabalhadores em partido político, e os proudhonianos, contrários a essa proposta.

Só no final da década de 1860, no Congresso de Basileia, houve o enfraquecimento das ideias proudhonianas na entidade, quando as ideias de Marx foram vitoriosas. ${ }^{11}$ Entretanto, ao mesmo tempo, a presença de Mikhail Bakunin nesse congresso, representando a seção francesa, colocou novamente em evidência na AIT, entre

10 A Encíclica Quod Apostolici Muneris, de Leão XIII, questionava a influência socialista e da Internacional sobre os trabalhadores (cf. Abendroth, 1977).

11 É importante destacar que nas discussões de algumas resoluções da AIT, Bakunin e Marx foram contrários às ideias proudhonianas de Tolain, que defendia a necessidade da existência da pequena propriedade individual. Mais detalhes, ver Colle, G.D.H (1986). 
outras coisas, a necessidade do apoliticismo da organização de trabalhadores.

A disputa entre Marx e Bakunin seria a tônica dos congressos seguintes ao da Basileia. Bakunin, de alguma forma influenciado pelas ideias proudhonianas, discordava da posição dominante no conselho geral, no qual os trabalhadores deveriam se reunir em partido político. Para o revolucionário russo, valendo-se dos estatutos da entidade e das palavras inaugurais, a emancipação da classe trabalhadora deveria ser obra da própria classe trabalhadora, e não de algum partido político, algo abertamente defendido por Marx desde o congresso de Londres de 1865. Para Abendroth (1977), essa disputa ocorria devido ao nível de organização industrial existente nos países representados na associação. Diz:

todos os congressos da Internacional passaram a se caracterizar pelo fato de que nas delegações dos países que estavam industrialmente muito desenvolvidos predominam as conceituações de Marx defendidas pela maioria do Conselho Geral, com o apoio, sobretudo, dos sindicatos ingleses, enquanto nas delegações dos países essencialmente agrários (então a Itália e a Espanha e, inicialmente, ainda, a França) ou representativas de regiões caracterizadas pela pequena empresa artesanal (à época a Suíça francesa), até a comuna parisiense (1871), predominavam conceitos proudhonísticos e, mais tarde, bakuninísticos. (Abendroth, 1977, p.37)

Independentemente de concordarmos ou não com a asserção de Abendroth (1977), o fato é que Bakunin novamente trouxe para o seio da Internacional a necessidade da organização dos trabalhadores não em partido político, mas em grupos autogeridos horizontalmente. Como afirma Samis (2007), sobre o Congresso de Basileia, em 1869,

Bakunin, em contraste com a corrente alemã que propunha uma orientação político-partidária para a Associação Internacional de 
Trabalhadores (AIT), defenderia a unidade econômica do proletariado. (Samis, 2007, p.10)

As divergências entre Marx e Bakunin, largamente conhecidas, levaram à expulsão do anarquista russo da AIT em 1871. Entretanto, se essa divergência estaria resolvida no âmbito da Internacional, não ocorria o mesmo com relação à organização do movimento operário em alguns países europeus (caso da França, Alemanha e da Itália), pois, mesmo com a vitória da ala marxista na Internacional, duas formas de organização do proletariado predominariam: a marxista, na qual o operariado se organizaria em partido político e, próximo ao partido, os sindicatos de trabalhadores, tendo como principal exemplo o Partido Social-Democrata Alemão; e a anarquista, na qual os trabalhadores se organizariam em associações sem vínculos partidários e teriam a greve geral como maior instrumento revolucionário. Para Bihr (1993),

A diferença radical entre sindicalismo revolucionário e sindicalismo social-democrata dava-se, neste ponto essencial, a autonomia estratégica, organizacional e cultural dos sindicatos reconhecida pelo primeiro e negada pelo segundo, que, em última análise, reduzia a função de "correia de transmissão" do partido, de acordo com a fórmula bem conhecida de Lênin, mas que a social-democracia anterior a 1914 já soubera colocar em prática. (Bihr, 1993, p.29)

As posições de Bakunin dentro da Internacional influenciariam o surgimento de uma vertente de extrema importância do sindicalismo mundial, com forte presença no Brasil no início do século XX:12 o

12 A maior presença do sindicalismo de orientação anarquista no país seria, segundo Fausto (1976), devido à fraca industrialização brasileira no início do século $\mathrm{XX}$, afirmando que nos países de maior industrialização, como a Alemanha, por exemplo, o sindicalismo predominante tinha orientação marxista (caso da influência do Partido Social-Democrata). Entretanto, cabe ressaltar que, embora a industrialização no país fosse ainda incipiente no limiar do século XX, onde ela prosperou (caso de São Paulo e Rio de Janeiro), a orientação libertária entre os sindicatos foi predominante, como demonstrou Batalha (2000). 
sindicalismo-revolucionário. Tendo como principais propostas a ação direta, a autogestão e a greve geral revolucionária, os sindicatos influenciados pelas propostas de Bakunin se espalharam por vários países da Europa (Portugal, Espanha, França, Itália, Bélgica, entre outros) e da América (EUA, México, Brasil, Argentina e Uruguai).

O caso mais próximo do sindicalismo de resistência no Brasil foi a CGT (Confédération Générale Du Travail). Essa entidade sindical surgiu em 1895 e a partir de seu congresso de 1906 tornou-se adepta das proposições anarquistas, como a ação direta, o apoliticismo, o federalismo, a greve geral funcionando como órgão de resistência dos operários na luta contra o capital. ${ }^{13}$ Sobre a influência do sindicalismo-revolucionário na CGT francesa, Samis (2007) aponta que:

Todos esses anarquistas de alguma forma buscavam resgatar a perspectiva de Bakunin. No caso francês, o da CGT - paradigma para o sindicalismo revolucionário em diversos países -, as táticas do boicote, sabotagem e da greve geral, combinadas ainda a uma profunda desconfiança em relação à política parlamentar, indicavam claramente a presença libertária na formulação dos postulados sindicais. (Samis, 2007, p.10)

A presença libertária na CGT no início do século XX evidencia que a supremacia das ideias marxistas na Primeira Internacional (1864-1872) e na Segunda Internacional (1889-1914) não foi suficiente para unificar o movimento sindical de cunho revolucionário. A experiência dos sindicatos franceses seria a base angular das proposições dos sindicalistas do início do século XX no Brasil. Largamente influenciados pela CGT francesa, inclusive mencionando

13 Segundo Toledo (2004, p.35), a CGT tinha como principais orientações políticas: “ $1^{\circ}$ ) Organizar os assalariados para a defesa de seus interesses morais e materiais, econômicos e profissionais. $2^{\circ}$ ) Organizar fora de todo partido político, todos os trabalhadores conscientes da luta a empenhar para a supressão do salariato [sic] e do patronato". 
essa ligação em seus estatutos, vários sindicatos brasileiros teriam algumas proposições do sindicalismo-revolucionário em várias de suas teses.

Muito embora a principal organização de trabalhadores do país no período em estudo não se declarasse anarquista, a influência de Bakunin era muito clara. Como afirmava Neno Vasco, ${ }^{14}$ participante direto das formulações estatutárias do $1^{\circ}$ Congresso Operário Brasileiro

O congresso não foi decerto uma vitória do anarquismo. Não o devia ser. A Internacional, desfeita por causa das lutas de partido no seu seio, deve ser memorável lição para todos. Se o congresso tivesse tomado caráter libertário, teria feito obra de partido, não de classe. O nosso fim não é constituir duplicatas dos nossos grupos políticos. Mas se o congresso não foi a vitória do anarquismo, foi, porém, indiretamente útil à difusão das nossas ideias. (Neno Vasco apud Leval, 2007, p.14)

Desta forma, as lutas sindicais desenvolvidas nesse período, apesar de algum espontaneísmo, eram substancialmente apoiadas em teoria e aceitas por boa parte da classe operária mundial, tais como a ação direta, a autogestão e a solidariedade operária. Uma das propostas dos sindicatos-revolucionários adotada no Brasil nos primeiros congressos da classe operária era a diferenciação entre os sindicatos de resistência e as outras agremiações sindicais. Para tal efeito, as entidades sindicais revolucionárias orientavam que as agremiações de resistência se utilizassem do nome "sindicato" em seus estatutos, procurando assim uma diferenciação dos outros agrupamentos operários que não tinham como principal preocupação fomentar entre os trabalhadores a busca por uma sociedade mais igualitária, se utilizando para isso do combate ao capital.

14 Advogado e anarquista português, uma das principais lideranças do movimento operário no início do século XX. 
Para Canêdo (1988), ${ }^{15}$ essa diferenciação era importante, pois

as primeiras organizações não tinham o nome de sindicato. Eram denominadas Associação Operária, Associação de Resistência, Aliança Operária, Sociedade União e Defesa etc. A designação do sindicato só começou a aparecer com mais frequência após a realização do Primeiro Congresso Operário, realizado em 1906, que aconselhou o seu uso para diferenciar as associações de resistência ao patronato daquelas de função beneficente. (Canêdo, 1988, p.36)

Essas entidades de resistência dependiam para a sua sustentação exclusivamente da cotização de seus filiados, possibilitando que fossem independentes, mas também efêmeras. Com grande influência das ideias anarquistas, como a defesa da ação direta, da autogestão operária e da destruição do Estado, esses sindicatos entendiam que a luta sindical era uma oportunidade de se colocar em prática alguns desses pressupostos classistas.

Isso ocorria porque, para essas agremiações, a luta contra o capital não se finalizava na conquista das melhorias desejadas, mas se expandiria na prática sindical, já que a forma de organização funcionaria para os trabalhadores como uma avant-première da nova sociedade. Como mostra Sferra (1987, p.10): "Através destes órgãos buscava-se conscientizar os trabalhadores de seus direitos imediatos como forma de conquista do bem-estar material e moral para a conscientização de classe".

Desta forma, a organização interna de um sindicato-revolucionário espelharia o modelo de organização social desejado pela classe operária numa possível sociedade futura, no qual

15 Batalha (2000), ao apontar as origens dos sindicatos no país, diz: "voltados para a 'ação econômica', os sindicatos enfrentavam questões como a jornada e as condições de trabalho, os salários, a forma de pagamento etc. Essas novas organizações surgiram com as denominações mais diversas: associação, centro, grêmio, liga, sociedade, união e, até mesmo, sindicato” (Batalha, 2000, p.15). 
a federação livre, grupos autônomas de trabalhadores podem e sabem melhor que outros organizar diretamente a produção e o consumo, ou todas as funções sociais úteis e necessárias. (Sferra, 1987, p.19)

Como a greve, a ação direta era um mecanismo de embate sindical que, afastando o operário da luta político-partidária, educá-lo-ia para a sua transformação. Ou seja, essa estratégia propiciaria que os operários, organizados sem a presença estatal ou partidária, demonstrassem a sua força por meio de uma ação sem intermediários, num processo no qual a luta cotidiana forjasse as bases de uma sociedade futura. Canêdo (1988) afirma que

A ação direta como instrumento de resistência ao capital deveria assumir a forma de greves (geral ou parcial), passando pelo boicote, queda do ritmo de trabalho, produção deliberadamente imperfeita, além das manifestações públicas. (Canêdo, 1988, p.40)

Os sindicatos-revolucionários estavam organizados por grande parte do país até fins da década de 1920. E essa organização tinha como objetivo a ruptura com uma ordem social totalmente desvantajosa para os trabalhadores, visto as más condições de trabalho, salário e de moradia. Neno Vasco apontava que a participação dos operários nessas entidades só ocorreria se essas entidades tivessem como princípio o "franco acesso, sem impedimentos nem taxas proibitivas, a sindicatos que não rejeitem nem expulsem ninguém por ideias e tenham para todas as opiniões a maior tolerância” (Vasco, 1984, p.125).

Interessante anotar que, se num primeiro momento, os sindicatos vão surgindo conforme as demandas específicas de cada ofício, aos poucos essa organização deixa a escala local (geralmente nas cidades mais industrializadas, como Rio de Janeiro e São Paulo) e vai se espalhando pelo território nacional, numa progressão que, para Moreira (1985), seguia a própria dinâmica industrial. ${ }^{16}$

16 Ao comentar sobre a dinâmica sindical desses sindicatos-revolucionários, Simão apontava que "O sistema de relações intersindicais ideado não era concentrado, 
Isso ocorria porque, para esse autor, conforme a economia fabril deixou de ser regional, o operariado, percebendo essa mudança escalar, também se tornou nacional. Diz:

Assim, quanto mais o espaço molecular se unifica e se torna nacional, mais se unifica e se torna nacional o operariado. [...] Como que em claro enunciado dessa configuração escalar, no período de 1917-1920 o movimento operário paralisa nacionalmente o trabalho, em greves que vão se sucedendo de um para outro lugar, sob uma só orientação e programa, do Rio Grande do Sul ao Pará, em greves gerais por todo o país (RS, SP, RJ, BA, PE, PA), anunciando sua maturidade como sujeito histórico. (Moreira, 1985, p.80)

Apesar de sua força estar demonstrada principalmente nas greves e manifestações ocorridas até a década de 1920, Antunes (1988) aponta que o sindicalismo-revolucionário teve grande expressividade em São Paulo até o início da década de 1930. Para ele, mesmo havendo um descenso dessa tendência sindical no movimento operário, após a Revolução de 1930,

não é verdadeira a afirmativa segundo a qual os anarcossindicalistas eram uma força secundária no início dos anos 1930; ao contrário, pelo menos até 1934, eles ainda constituíam força significativa em termos de penetração no movimento sindical. (Antunes, 1988, p.103)

Por essa análise inicial, percebemos que os sindicatos-revolucionários - chamados por grande parte dos historiadores e cientistas sociais que estudam o movimento operário brasileiro, entre eles Antunes, também de anarcossindicalistas ${ }^{17}$ - tiveram expressiva

mas fluido; e as formas de controle associativo não eram centralizadas, mas difusas e orientadas dos grêmios para o órgão federativo" (Simão, 1966, p.194).

17 Ao utilizarmos prioritariamente o termo sindicalista-revolucionário, temos consciência de que a maioria dos militantes dos sindicatos era anarquista. Entretanto, 
importância na organização do movimento operário no país, mas também destacado papel no sindicalismo mundial.

De outra parte, a ala marxista desdobrada da I Internacional teve como sua maior expressão, antes da Primeira Guerra Mundial, o Partido Social-Democrata Alemão, principal organizador da classe operária alemã e, posteriormente à guerra, na influência marcante dos bolchevistas russos. ${ }^{18}$ Em que pesem a lei contrária ao socialismo de 1878 (Lei promovida pelo governo Bismarck) e, posteriormente, a própria introdução de várias normatizações nas relações entre o capital e o trabalho pelo II Reich (1881), ${ }^{19}$ o partido social-democrata alemão, ano após ano, angariava adeptos entre os operários. Como aponta Abendroth (1977), "os sindicalistas cresciam rapidamente. Se em 1892 contavam apenas com 300 mil associados, já em 1899, incluindo os fracos sindicatos cristãos, tinham 600 mil, em 1913, 2,5 milhões" (Abendroth, 1977, p.47).

Estavam organizados por quase toda a Alemanha e, desde 1892, no congresso sindical de Halberstadt, centralizaram as federações sindicais tendo em consideração o princípio profissional (Abendroth, 1977). Diferentemente dos sindicatos-revolucionários que questionavam o real uso e a validade das reformas trabalhistas numa sociedade capitalista e, desta forma, negavam a participação em qualquer jogo político partidário, os social-democratas viam a luta

não usamos o cognome "anarcossindicalista", pois, ao defenderem a autonomia do sindicato, esses militantes defendiam uma entidade na qual as diferenças políticas ou religiosas não provocassem discórdias internas que pudessem levar a uma divisão da organização ou, no caso extremo, ao seu próprio fim.

18 Ao apontarmos o Partido Social-Democrata Alemão com uma ala importante do marxismo, no que tange à ação sindical, levamos em consideração também a influência, despertada por suas ideias, na organização de vários partidos pelo mundo. Como afirma Andreucci (1985), “entre 1890 e o final do século estava situado o período da maior expansão através da social-democracia alemã, na influência das ideias que ela representava todos os partidos socialistas criados após essa data declararam expressamente que assumiam os modos de ser, o programa e a doutrina da social-democracia alemã” (Andreucci, 1985, p.28).

19 Entre as leis surgidas, temos as que instituíram o seguro-invalidez, o seguro-acidente e o seguro-doença. 
parlamentar como um caminho possível à superação do sistema capitalista e à emergência de uma sociedade mais igualitária.

Para isso, seria imprescindível a arregimentação da classe operária ao partido e, por conseguinte, à organização sindical de caráter social-democrata, como forma de ascender ao poder e lentamente estabelecer marcos sociais mais profundos. ${ }^{20}$ Desta forma, o projeto social-democrata entendia que a organização sindical poderia ser um veículo importante para a conquista do Estado pelo proletariado, sendo que, quanto maior a presença dos sindicatos social-democratas entre os trabalhadores, maior seria, pelo menos na teoria, a proporção de cadeiras do partido no parlamento.

A opção da conquista do Estado como maneira inexorável de emancipação do proletariado fazia que tais sindicatos vissem

o Estado como a via obrigatória e inevitável da emancipação do proletariado. E a sociedade supostamente resultante dessa revolução política (o socialismo) é então assimilada a um processo mais ou menos radicalizado de estatização do capitalismo. (Bihr, 1993, p.20)

O fato é que, ao chegarem efetivamente ao poder (na República de Weimar), os social-democratas implementaram uma política repressiva aos partidos mais revolucionários (como o Partido Comunista), dando-se que a possibilidade de se chegar ao socialismo seria pouco provável. Com uma tática diversa daquela do Partido Social-Democrata Alemão, surge no início do século XX (1903) na Rússia, fruto da divisão do Partido Operário Social-Democrata Russo (POSDR), uma ala marxista revolucionária, que tinha Lênin como principal liderança.

Esses marxistas revolucionários acreditavam que os sindicatos poderiam servir como formadores de opinião da classe operária,

20 Para Bihr, o projeto social-democrata "é progressivamente reduzido, nessa via, a uma simples democratização da sociedade capitalista, à concretização, na sociedade civil, dos direitos e ideais da democracia política (liberdade, igualdade, fraternidade), que as informações de estruturas anteriormente indicadas devem realizar progressivamente" (Bihr, 1993, p.21). 
incentivando-os a trabalharem em consonância com o partido. Uma das principais resoluções do Congresso de 1906 do POSDR dizia taxativamente que:

O partido deve procurar, por todos os meios, educar os operários filiados aos sindicatos no espírito de uma ampla compreensão da luta de classes e das tarefas socialistas do proletariado, a fim de conquistar realmente, com sua atividade, o papel dirigente nos referidos sindicatos; e, por último, para que estes sindicatos possam, em determinadas condições, aderir diretamente ao partido, mas sem excluir deles, de modo algum, os seus filiados que não militam no Partido. (Lênin, 1979, p.104)

As ideias de Lênin sobre os sindicatos aos poucos ganhariam prevalência no partido social-democrata russo e, principalmente na sua ala mais revolucionária, a ala bolchevique, essas ideias funcionariam como um norte. Após a Revolução Russa de 1917, a ampla maioria dos partidos comunistas nacionais teve-as como uma tática de conquista de poder pelo proletariado.

Um dos principais fóruns de debate sindicais desse período pós-revolucionário, ligado diretamente à III Internacional, foi a Internacional Sindical Vermelha (ISV), fundada em Moscou em 1920. Como uma espécie de órgão superior dos sindicatos marxistas revolucionários, a ISV tinha como alvo as políticas social-democratas e sindicalistas-revolucionárias, consideradas reformistas ou pequeno-burguesas.

Com relação à social-democracia, a ISV conclamava as massas operárias a abandonarem o que chamava os "dirigentes reformistas" e a aceitarem novamente a ação violenta como uma tática importante na luta sindical. Incentivavam a criação de sindicatos por indústria, já que havia uma grande concentração de capital e condenavam o sindicato por ofício, que taticamente não conseguiria ser um forte interlocutor nesse processo. Eram a favor da unicidade sindical e que, obviamente, as categorias estivessem atreladas ao sindicato único de orientação comunista, de forma que 
os trabalhadores fossem formados ideologicamente pelo marxismo revolucionário. ${ }^{21}$

Mesmo sendo contrários à tática parlamentar dos social-democratas, não abriam mão totalmente da ação parlamentar. Embora concordassem com a ação direta, diziam que ao contrário de "como fazem os anarquistas, que fora da ação imediata não existem outras formas de ação", para os comunistas "a ação direta não exclui a luta parlamentar, é seu fundamento” (A concepção marxista..., 1994, p.22). Mesmo aderindo ao parlamentarismo procuravam se diferenciar dos social-democratas, afirmando que

naturalmente, não falamos aqui de uma luta parlamentar como a que concebem e praticam os reformistas e social patriotas, que consideram que seu objetivo consiste em colocar-se no mesmo nível que os demais partidos políticos. (In: A Concepção Marxista de Sindicatos - O Programa de Ação da Internacional Sindical Vermelha. São Paulo: Outubro, 1994, p.22.)

No início da década de 1920, na Rússia, os sindicatos já estavam sendo praticamente estatizados. Se em 1918 e 1919 a ideia de uma gestão da economia pelos sindicatos livres teve grande ressonância, principalmente entre a Oposição Operária, as ideias que predominariam na década de 1920 seriam aquelas defendidas por Lênin, que, no II Congresso de Sindicatos, proclamava que "a estatização dos sindicatos é inevitável, sua fusão com os órgãos do Estado é inevitável, a transferência de todo o edifício da grande produção para as suas mãos é inevitável" (Lênin apud Hegedus, 1986, p.21). Ou seja, a possibilidade de se manter os sindicatos independentes do Estado era impensável, um desvio pequeno-burguês e que

21 Dizia o texto da ISV: "Quais são os princípios fundamentais de um sindicato industrial? São muito simples: todos os operários e todos os empregados de uma empresa devem filiar-se ao mesmo sindicato. [...] Nossa luta é: uma empresa, um sindicato" (A concepção marxista de sindicatos, 1994, p.26). 
por isso, as concepções da Oposição Operária e dos elementos análogos não são apenas teoricamente falsas, como constituem praticamente a expressão das vacilações pequeno-burguesas e anarquistas, debilitam na prática a linha de firme direção do Partido Comunista e, de fato, ajudariam os inimigos de classe da revolução proletária. (Lênin, 1979, p.212)

Enquanto participante dessas ideias, o Partido Comunista no Brasil apoiaria também a instalação do sindicato por indústria, bem como a política de unicidade sindical (aqui combatendo diretamente os sindicatos-revolucionários, embora legatário dessa tradição). No Brasil, o surgimento do Partido Comunista teve como forte motivador a Revolução de outubro/novembro de 1917 na Rússia, marcando o surgimento de divisões no sindicalismo-revolucionário. Essa fragmentação seguirá por toda a década de 1920 e 1930, ocorrendo casos em que os anarquistas acusavam os comunistas de sabotarem as lutas libertárias. Dulles (1977) aponta que, em maio de 1932, durante um protesto contra a adoção da carteira de trabalho, Oiticica e Leuenroth, grandes expoentes do sindicalismo-revolucionário e anarquistas, acusavam que a

Greve Geral conclamada pela Federação Operária [...] seria certissimamente vitoriosa se os comunistas tivessem cooperados. Oiticica acusou-os de traírem a campanha anarquista, aceitando as carteiras profissionais com o fim de detonar a reivindicação dos anarquistas. (Dulles, 1977, p.400)

Se num primeiro momento a Revolução na Rússia, liderada pelos bolcheviques, foi vista por parte do operariado brasileiro como a consumação de suas ideias, aos poucos as notícias de mortes e prisões nos jornais anarquistas e sindicalistas do mundo todo começaram a preocupar algumas lideranças sindicais. No Brasil, os principais militantes sindicalistas-revolucionários se dividiram entre aqueles que apoiavam peremptoriamente o novo regime (caso de Astrojildo Pereira, editor do jornal Spartacus, e importante força intelectual do 
anarquismo no Rio de Janeiro) e os sindicalistas avessos e desiludidos com o encaminhamento do processo revolucionário na Rússia, como Edgar Leuenroth, editor do jornal A Plebe e importante liderança na Greve Geral de 1917 em São Paulo.

Em meio a esse debate, passa pelo Brasil um enviado da III Internacional que se surpreende pela não presença no país de um partido comunista. Esse emissário a princípio conhece Leuenroth, que se nega a criar tal partido, visto que não era bolchevista. Entretanto, com a insistência do maximalista, apresenta Astrojildo Pereira, o qual seria incumbido da tarefa. Em 1922 é fundado o Partido Comunista. Em seu comitê central encontravam-se vários ex-anarquistas, como Astrojildo Pereira, João da Costa Pimenta e Antonio Canellas.

Diferentemente da corrente sindicalista-revolucionária, que pregava maior autonomia na organização interna do sindicato e de suas relações com os congêneres, os comunistas se pautariam pela maior centralização política, a qual seria "a base, o centro, a condição mesma de desenvolvimento e fortalecimento da ação sindical de massas" (Pereira, 1976, p.91).

No que tange à ação territorial, esses sindicalistas apoiavam a ampliação da base territorial das agremiações sindicais, da escala municipal para a escala intermunicipal. Dulles (1977), ao analisar o jornal A Classe Operária, órgão oficial do Partido Comunista, demonstrou a preferência dos comunistas pelos sindicatos por indústria e a crítica a alguns sindicatos que se mantinham ligados ainda à divisão administrativa oficial. Para o autor, os comunistas defendiam

a causa com a indagação do que aconteceria se todos os trabalhadores da Light estivessem organizados segundo a classificação sindical de cada um. Persuadiu a se organizarem com um correspondente grau de centralização, para dar combate à centralização cada vez maior do capitalismo, e propôs o fim da observância rigorosa, por parte dos sindicatos das divisões municipais traçadas pela burguesia; não via razão alguma para a existência de um sindicato de sapateiros no Rio e outro em Niterói. (Dulles, 1977, p.227) 
Conforme a década de 1920 avançava, o combate comunista aos sindicatos de maior influência libertária era cada vez maior. ${ }^{22}$ Como forma de promover a unidade da classe operária sob a sua tutela, a chamada unicidade sindical, o Partido Comunista, segundo Batalha (2000), "gerou em termos práticos a aliança em 1923 com a reformista Confederação Sindicalista Cooperativista Brasileira, visando reduzir a influência anarquista nos sindicatos e tomar-lhes o controle dessas organizações" (Batalha, 2000, p.36).

Além dessas prerrogativas, o Partido Comunista tentaria a formação de uma confederação de sindicatos no país, a CGT (Confederação Geral do Trabalho). Entretanto, para Dulles (1977), seu resultado não foi expressivo, pois de "1,5 milhão de operários e assalariados da indústria em geral, apenas cerca de 100 mil se achavam organizados em sindicatos ou sociedades operárias mistas" (Dulles, 1977, p.305). ${ }^{23}$

No III Congresso do Partido Comunista do Brasil em 1929, algumas das principais questões discutidas se ligavam à necessidade de maior penetração das ideias comunistas nos meios sindicais e os meios necessários para extinguir possíveis resquícios de anarquismo nessas entidades. É o que vemos nas formulações propostas por Astrojildo Pereira para se discutir no Congresso, debatidas em vários números de A Classe Operária, entre as quais,

a atividade dos comunistas nos sindicatos operários, a linha política e tática do Partido no Bloco Operário e Camponês, o problema camponês, a Juventude Comunista e o Partido, o caráter da revolução brasileira, a luta contra o anarcossindicalismo [...]. (Pereira, 1976, p.136)

22 Salles (2005) comenta que as disputas pela direção de sindicatos entre os comunistas e os anarquistas resultaram, em alguns casos, em agressão física, e, inclusive, mortes. Foi o que aconteceu em 1928, quando três anarquistas foram mortos por comunistas na disputa pela hegemonia da União dos Trabalhadores Gráficos do Rio de Janeiro.

23 Batalha (2009, p.217) aponta a formação em 1929 da Confederação Geral do Trabalho no Brasil, com a presença de delegações de dez unidades da federação. 
A divisão da classe operária se tornou cada vez mais patente. Como se não bastassem os sindicatos reformistas, beneficentes/ mutuais e católicos, a inserção dos comunistas nos sindicatos trouxe outra divisão entre as agremiações que lutavam abertamente contra o capital. Nesse sentido, a fragmentação dos sindicatos de matriz revolucionária em dois grupos (comunistas e sindicalistas-revolucionários) deixou-os envolver nas crises do sistema de alianças da classe dominante, fazendo-os recolher de tais lutas exatamente o seu lado pior, as derrotas (Zaidan, 1988).

Uma demonstração disso foi a comemoração do $1^{\circ}$ de Maio de 1929 no Rio de Janeiro, relatada por Dulles (1977),

O comício [comunista] da Praça Mauá foi bastante concorrido, calculando-se a assistência em mais de 10 mil pessoas. Um menor número de operários respondeu ao apelo da FORJ e da União dos Operários em Construção Civil para celebrar a data na Praça Onze de Junho, onde Romeu Boleli, Antônio Leite e seus companheiros anarcossindicalistas verberaram acremente o autoritarismo e incitaram os ouvintes a se congregarem pela liberdade da classe operária. (Dulles, 1977, p.312)

Para Zaidan (1988), a entrada dos comunistas nos sindicatos e a posterior luta contra os sindicalistas-revolucionários, e a política de maior coação das entidades de classe ${ }^{24}$ realizada pelo governo, contribuíram para um meio sindical mais enfraquecido. As políticas de coação se tornaram mais intensas a partir de 1924 em São Paulo, graças à existência de uma polícia política, o Dops. Analisando alguns prontuários desse departamento de repressão política, percebemos que essas divisões entre os sindicatos mais combativos eram atentamente observadas, sendo inclusive incentivadas como forma

24 Entre outras ações estatais contra os sindicatos mais combativos, temos a criação, pelo governo Artur Bernardes, de uma colônia penal em Clevelândia, extremo norte do país, onde vários militantes operários pereceram. Mais detalhes, ver Samis (2004). 
de enfraquecer essas entidades. Diz um desses relatórios, assinado pelo informante da polícia Antonio Ghioffi

Em São Paulo, a ação do Partido Comunista, da Confederação Geral do Trabalho e da Federação Sindical Regional, tem sido embargada, em grande parte, por uma táctica inteligente desenvolvida pela Delegacia de Ordem Social que, aproveitando a posição ideológica das correntes predominantes no seio do proletariado militante, fez que prevalecesse o critério apolítico nas organizações que, apesar de discutido com os seus acendrados [apurados] mentores, teoricamente estão, quer queira quer não, de acordo com o apoliticismo da lei de sindicalização do Ministério de Trabalho. Esta tática produziu os melhores resultados, trazendo consequentemente uma sensível divisão de forças nas diversas facções sindicais existentes. (Relatório de 10 de junho de 1931. Pront 716, Federação Operária de São Paulo, vol. 3, Dops)

É importante perceber até aqui que a influência dessas tendências no sindicalismo brasileiro até meados da década de 1920 é inegável, seja pelo sindicalismo-revolucionário na $\mathrm{COB}^{25}$ ou o marxismo revolucionário no Partido Comunista.

Como mostraremos adiante, essa luta operária incomodaria enormemente as elites nacionais, culminando no início da década de 1930 com uma maior ação estatal nos sindicatos, coibindo num primeiro momento e em seguida proibindo terminantemente quaisquer manifestações livres dos trabalhadores. Uma ação estatal cada vez mais

25 A COB (Confederação Operária Brasileira) foi a entidade máxima do sindicalismo-revolucionário, tendo sido fundada em 1908 e sendo seu porta-voz o jornal A Voz do Trabalhador. Segundo Batalha (2008), essa entidade nacional existiu durante dois períodos (1908-1909; 1913-1915) e funcionou como centralizadora das atividades sindicais, sem necessariamente abrir mão da autonomia dos sindicatos. Entretanto, cabe ressaltar que, analisando o jornal A Plebe do ano de 1917, percebemos a presença de dois artigos, chamando os sindicatos para a realização de um congresso operário em outubro daquele ano, no qual expressamente citam a entidade nacional. 
repressora no final da década de 1920 nos sindicatos comunistas ou sindicalistas-revolucionários e a completa cisão entre essas correntes propiciaram um controle quase que total dos sindicatos pelo Estado a partir de 1930, com a lei de sindicalização.

Entretanto, essa discussão será feita no próximo capítulo, quando abordaremos a ação sindical dentro do Estado corporativo. Agora, nossas atenções se prendem sobre as territorialidades dos sindicatos-revolucionários, no período de prevalência de um Estado liberal.

\section{2 - As territorialidades do movimento sindical no Brasil até o Início da década de 1920.}

Com a entrada dos imigrantes, aportaram no país também militantes que já desenvolviam atividades de organização operária de caráter revolucionário, trazendo então às terras tropicais ideias sociais que já tinham enorme repercussão na Europa, como o anarquismo e o sindicalismo-revolucionário. Os militantes anarquistas, organizados em sindicatos (comentados por diversos historiadores e sociólogos como anarcossindicalistas ou, minoritariamente, de sindicalistas-revolucionários), seja pela sua maior coerência ideológica, por formarem organizações mais sólidas ou pela presença de grandes publicações e movimentos de greve, foram majoritários até meados da década de 1920.

Como vimos antes, apesar de defenderem as ideias anarquistas, seus principais expoentes no movimento operário eram a favor da neutralidade da entidade. Mesmo assim, essas agremiações não compactuavam com partidos, nem seus filiados participavam da luta parlamentar. Esses sindicatos subsistiam graças ao árduo trabalho dos militantes e filiados, já que possuíam como única receita a contribuição espontânea de seus membros, ocorrendo que muitas entidades surgiam em um momento de grande efervescência (como a Greve Geral de 1917) e, passado o evento, sucumbiam. 
Isso poderia ocorrer por não terem alcançado seus objetivos e gerado desconfiança entre os filiados, ou na maior parte, como efeito da repressão que sofriam do Estado, por meio de empastelamentos, ${ }^{26}$ prisões e deportações de seus melhores militantes.

Nesse período inicial (até meados da década de 1920), havia pouca intervenção do Estado nas relações entre o capital e o trabalho. A presença estatal era quase toda ligada à repressão ao movimento operário, por meio das investiduras policiais. Entretanto surgiram algumas leis trabalhistas.

A principal norma foi o Decreto n.1637, de 5 de janeiro de 1907. Um dos artigos centrais desse decreto versava sobre a questão territorial.

Ao analisarmos esse decreto percebemos que o Estado não interferia de forma sistemática nas relações entre os sindicatos, fossem estas municipais, estaduais ou nacionais, propiciando várias conexões entre os mesmos, fossem estas econômicas, sociais e políticas.

Com esse decreto, predominava no país a partir de então a pluralidade sindical, ou seja, não haveria restrições para a fundação de dois ou mais sindicatos de uma mesma categoria, numa mesma base territorial.

Desta forma, o decreto permitiria diversas formas de relações interterritoriais entre os sindicatos, possuindo forte influência federalista. ${ }^{27}$ Entretanto, como veremos, seria incorreto afirmar que o decreto unicamente foi o incentivador dessas relações.

As múltiplas territorialidades sindicais desse período ocorreram para nós muito mais pela predominância das ideias revolucionárias nos sindicatos, do que propriamente pelo poder do decreto.

Oreste Ristori, Gigi Damiani, Neno Vasco e Edgar Leuenroth estavam entre os principais nomes do movimento sindical desse período

26 Expressão muito comum no início do século XX, empastelamento, segundo o Dicionário Houaiss (2001), significa "destruir as instalações de um jornal, revista etc. por motivos políticos ou pessoais".

27 Moraes Filho (1978) aponta que essa lei foi largamente baseada na legislação sindical francesa de 1884, a qual permitia grande pluralidade sindical. 
e sempre serão lembrados pelo que representavam na organização dos trabalhadores, em um momento no qual os operários estavam desarticulados e entregues aos mandos e desmandos dos patrões.

A luta desses imigrantes e filhos de imigrantes, mas também de milhares de brasileiros natos, foi de crucial importância para que, mesmo com uma repressão feroz do Estado e dos empresários, o movimento sindical-revolucionário tivesse força para realizar três congressos em nível nacional. O I Congresso Operário Brasileiro realizou-se no Rio de Janeiro, de 15 a 22 de abril de 1906, e contou com a participação de representantes de vários estados. Conforme a descrição de Hardman (1982) as entidades de classe que aceitaram o convite foram:

Tabela 1 - Entidades participantes do $1^{\circ}$ congresso operário brasileiro

\begin{tabular}{|c|c|c|}
\hline Estado & Cidade & Entidade \\
\hline \multirow[t]{6}{*}{ São Paulo } & São Paulo & União dos Trabalhadores Gráficos \\
\hline & Santos & Sociedade Internacional de \\
\hline & & Operários \\
\hline & Campinas & União Operária \\
\hline & Campinas & União dos Trabalhadores Gráficos \\
\hline & Ribeirão Preto & União Operária \\
\hline Ceará & - & Centro Artístico Cearense \\
\hline Pernambuco & - & Centro Protetor dos Operários \\
\hline Bahia & - & Federação Socialista \\
\hline Alagoas & Maceió & União Operária \\
\hline \multirow[t]{2}{*}{ Minas Gerais } & Vila Nova Lima & Junta Auxiliadora dos Operários \\
\hline & Juiz de Fora & Centro das Classes Operárias \\
\hline $\begin{array}{l}\text { Rio Grande } \\
\text { do Sul }\end{array}$ & - & União Operária \\
\hline \multirow[t]{3}{*}{ Rio de Janeiro } & Niterói & Centro Operário Fluminense \\
\hline & Campos & Centro Operário \\
\hline & Campos & União dos Artistas \\
\hline Antigo & Rio de Janeiro & União dos Operários das Pedreiras \\
\hline \multicolumn{3}{|l|}{ Distrito } \\
\hline Federal & & \\
\hline
\end{tabular}




\begin{tabular}{|c|c|c|}
\hline \multirow[t]{22}{*}{ Estado } & Cidade & Entidade \\
\hline & Rio de Janeiro & $\begin{array}{l}\text { Assoc. de Resistência dos Trab. Em } \\
\text { Carvão Mineral }\end{array}$ \\
\hline & Rio de Janeiro & Centro dos Operários Marmoristas \\
\hline & Rio de Janeiro & União dos Operários Estivadores \\
\hline & Rio de Janeiro & $\begin{array}{l}\text { Centro dos Empregados em } \\
\text { Ferrovias }\end{array}$ \\
\hline & Rio de Janeiro & União dos Chapeleiros \\
\hline & Rio de Janeiro & União dos Corrieiros e Artes \\
\hline & & Correlativas \\
\hline & Rio de Janeiro & Liga Operária Italiana \\
\hline & Rio de Janeiro & Liga dos Artistas Alfaiates \\
\hline & Rio de Janeiro & União dos Carpinteiros e Artes \\
\hline & Rio de Janeiro & $\begin{array}{l}\text { Correlativas } \\
\text { União dos Manipuladores de } \\
\text { Tabaco }\end{array}$ \\
\hline & Rio de Janeiro & $\begin{array}{l}\text { Assoc. de Resistência dos Trab. Em } \\
\text { Trapiches e Café }\end{array}$ \\
\hline & Rio de Janeiro & $\begin{array}{l}\text { Centro dos Operários do Jd. } \\
\text { Botânico }\end{array}$ \\
\hline & Rio de Janeiro & Liga das Artes Gráficas \\
\hline & Rio de Janeiro & União dos Maquinistas Terrestres \\
\hline & Rio de Janeiro & $\begin{array}{l}\text { Liga dos Carpinteiros e Calafates } \\
\text { Navais }\end{array}$ \\
\hline & Rio de Janeiro & $\begin{array}{l}\text { União dos Recebedores } \\
\text { em Ferrocarris }\end{array}$ \\
\hline & Rio de Janeiro & $\begin{array}{l}\text { Sociedade de Classes dos } \\
\text { Marceneiros }\end{array}$ \\
\hline & Rio de Janeiro & $\begin{array}{l}\text { Soc. Protetora dos Operários } \\
\text { Funileiros, Bombeiros e Gasistas }\end{array}$ \\
\hline & Rio de Janeiro & Centro Internacional dos Pintores \\
\hline & Rio de Janeiro & $\begin{array}{l}\text { União Operária do Engenho de } \\
\text { Dentro }\end{array}$ \\
\hline
\end{tabular}

(Organizador: Amir El Hakim de Paula apud Hardman, 1982)

No primeiro congresso operário brasileiro foram afirmados alguns princípios sindicalistas-revolucionário, tais como a autogestão, 
o federalismo, a autonomia nas diversas esferas, o enfrentamento de classes, a necessidade de criação de sindicatos de ofícios vários quando a categoria não conseguisse ainda ter uma organização independente.

Analisando a tabela 1 percebemos que a maior concentração de entidades estava no antigo Distrito Federal (atual cidade do Rio de Janeiro), com 21 associações, o que revela como apontou Bernardo (1982), "a estreita correlação entre a concentração da atividade industrial e a aglutinação da mão-de-obra assalariada" (Bernardo, 1982, p.43).

Mesmo assim, a tabela 1 demonstra a preocupação dos operários em se organizarem nos vários estados do país, desde os mais industrializados, como São Paulo e Minas Gerais, como também aqueles mais distantes dos grandes centros, casos de Alagoas e Ceará. Como resultado desse congresso, foi lançado em 1908 o jornal A Voz do Trabalhador, periódico de grande importância para a articulação do movimento operário nacional, bem como formada a Confederação Operária Brasileira.

Algumas diretrizes foram definidas e posteriormente ratificadas no $2^{\circ}$ e $3^{\circ}$ Congressos operários. Entre as principais temos:

- $1^{\circ}$ ) Somente seriam filiados sindicatos de trabalhadores assalariados e que tivessem a resistência ao capital como norma.

- $2^{\circ}$ ) As entidades se organizariam em Federações locais ou estaduais de indústria ou de ofício; Federações locais ou estaduais de sindicatos; sindicatos isolados de lugares onde não existiam federações locais ou estaduais, ou de indústria ou de ofício não confederados.

- $3^{\circ}$ ) Os funcionários dos sindicatos eram operários eleitos para funções administrativas e não diretivas.

- $4^{\circ}$ ) Propugnava a defesa das 8 horas de trabalho para todos os trabalhadores.

- $5^{\circ}$ ) A defesa de várias técnicas de luta contra o patronato, entre elas, a greve parcial ou geral, a boicotagem, a sabotagem, o labéu [injúria] e a manifestação pública. 
- $6^{\circ}$ ) O Congresso manifestava-se contra a existência de "títulos honoríficos" e de distinção na organização operária. ${ }^{28}$

No período entre o primeiro e o segundo congresso, segundo as análises de Hardman (1982), grandes greves ocorreram, como a dos ferroviários de São Paulo em 1906 contra a presença de um chefe de linha, ${ }^{29}$ trabalhadores da Light em 1909 em luta pelas oito horas, trabalhadores das docas do Porto de Santos em 1908 que, segundo Hardman (1982), p.341, "paralisou toda a cidade, com violentos choques de rua e até mesmo a presença intimidatória de dois navios de guerra, enviados pelo governo federal".

O II Congresso Operário ocorreu entre 8 e 13 de setembro de 1913, no Rio de Janeiro, e contou com a participação de várias entidades de trabalhadores organizados, em sua grande maioria, sob o sindicalismo-revolucionário. As entidades que aderiram ao encontro operário foram:

Tabela 2 - Entidades participantes do $2^{\circ}$ congresso operário brasileiro

\begin{tabular}{lll}
\hline Estado & Cidade & Entidade \\
\hline Antigo & Rio de Janeiro & Federação Operária \\
Distrito & Rio de Janeiro & Centro dos Operários Marmoristas \\
Federal & Rio de Janeiro & Sindicato dos Sapateiros \\
& Rio de Janeiro & Sindicato dos Carpinteiros \\
& Rio de Janeiro & Sindicato dos Operários das \\
& Redreiras \\
& Rio de Janeiro de Janeiro & Sindicato dos Estucadores \\
& Sindicato dos Operários em \\
& Ladrilhos e Mosaicos \\
& Rio de Janeiro & Sindicato dos Trabalhadores em \\
& & Fábrica de Tecidos \\
\hline
\end{tabular}

28 Apud Hardman (1982, p.338).

29 Essa greve está discutida mais detalhadamente no subcapítulo 3.3. 


\begin{tabular}{|c|c|c|}
\hline \multirow[t]{2}{*}{ Estado } & Cidade & Entidade \\
\hline & \multirow[t]{2}{*}{ Rio de Janeiro } & Sindicato Operário de Ofícios \\
\hline & & Vários \\
\hline & \multirow[t]{2}{*}{ Rio de Janeiro } & Sindicato dos Operários de \\
\hline & & Indústria Elétrica \\
\hline & \multirow[t]{2}{*}{ Rio de Janeiro } & Sindicato dos Marinheiros e Artes \\
\hline & & Correlativas \\
\hline & Rio de Janeiro & União dos Alfaiates \\
\hline & Rio de Janeiro & União Geral dos Pintores \\
\hline & Rio de Janeiro & Fênix Caixeiral \\
\hline & Rio de Janeiro & Centro Cosmopolita \\
\hline & \multirow[t]{2}{*}{ Rio de Janeiro } & Associação dos Empregados \\
\hline & & Barbeiros e Cabeleireiros \\
\hline & Rio de Janeiro & $\begin{array}{l}\text { Liga Federal dos Empregados em } \\
\text { Padaria }\end{array}$ \\
\hline & \multirow{3}{*}{ Rio de Janeiro } & Sociedade de Resistência dos \\
\hline & & Trabalhadores em Trapiches e \\
\hline & & Cafés \\
\hline & Rio de Janeiro & Sociedade Fraternidade e Progresso \\
\hline Amazonas & Manaus & Associação das Artes Gráficas \\
\hline Pará & Belém & União dos Operários Sapateiros \\
\hline \multirow[t]{4}{*}{ Alagoas } & Maceió & Federação Operária \\
\hline & Maceió & Sindicato dos Marceneiros \\
\hline & - & Sindicato dos Estivadores \\
\hline & - & Sindicato dos Gráficos \\
\hline \multirow[t]{8}{*}{ Rio de Janeiro } & Niterói & Círculo Operário Fluminense \\
\hline & Niterói & Sindicato Operário de Ofícios \\
\hline & & Vários \\
\hline & Niterói & Sindicato dos Estucadores e \\
\hline & & Pedreiras \\
\hline & Niterói & Sindicato dos Tecelões e Artes \\
\hline & & Correlativas \\
\hline & Petrópolis & Centro Operário Primeiro de Maio \\
\hline \multirow[t]{5}{*}{ Minas Gerais } & Belo Horizonte & Centro Operário Sindicalista \\
\hline & Belo Horizonte & Sindicato dos Pedreiros \\
\hline & Belo Horizonte & Sindicato dos Carpinteiros \\
\hline & - & Associação Beneficente Irmãos \\
\hline & & Artistas \\
\hline
\end{tabular}




\begin{tabular}{|c|c|c|}
\hline Estado & Cidade & Entidade \\
\hline \multirow{21}{*}{ São Paulo } & Juiz de Fora & União Operária \\
\hline & Machado & Liga Operária \\
\hline & São Paulo & Sindicato Operário de Ofícios \\
\hline & & Vários \\
\hline & São Paulo & Sindicato dos Canteiros \\
\hline & São Paulo & União Gráfica \\
\hline & São Paulo & União dos Chapeleiros em Geral \\
\hline & São Paulo & Lega Fra Pastae e Afini \\
\hline & Santos & Federação Operária \\
\hline & Santos & Sindicato dos Pedreiros e Serventes \\
\hline & Santos & Sindicato dos Carpinteiros e Artes \\
\hline & & Correlativas \\
\hline & Santos & $\begin{array}{l}\text { Sindicato dos Operários em Pedras } \\
\text { e Granito }\end{array}$ \\
\hline & Santos & $\begin{array}{l}\text { Sindicato dos Carroceiros e } \\
\text { Chaffeurs }\end{array}$ \\
\hline & Cravinhos & União Operária \\
\hline & Franca & União Operária Beneficente \\
\hline & Jaú & Centro Operário Beneficente e \\
\hline & & Instrutivo \\
\hline & Batatais & Liga Operária \\
\hline & Campinas & Liga Operária \\
\hline & Ribeirão Pires & Sindicato dos Canteiros \\
\hline \multirow{5}{*}{$\begin{array}{l}\text { Rio Grande } \\
\text { do Sul }\end{array}$} & Porto Alegre & Federação Operária \\
\hline & Porto Alegre & União Tipográfica \\
\hline & Passo Fundo & Centro dos Trabalhadores \\
\hline & Pelotas & Federação Operária \\
\hline & Bagé & Sociedade Beneficente dos Alfaiates \\
\hline
\end{tabular}

(Org. Amir El Hakim de Paula apud Rodrigues, 1979)

Interessante anotar que, por exemplo, a Federação Operária do Rio Grande do Sul, em que pese estar localizada e prioritariamente organizar o operariado de Porto Alegre, segundo Rodrigues (1979), também tinha entre seus filiados, sindicatos das cidades de Rio Grande, Santa Maria, Caxias e Montenegro. No II Congresso se rea- 
firmaram os postulados sindicalistas-revolucionários e, ao contrário do primeiro, já se via uma maior organização da classe operária, fato esse demonstrado pela grande atividade sindical ocorrida entre os dois congressos. Isso ocorreu devido à predominância de intensas greves no período que vai do primeiro ao segundo, bem como à luta dos trabalhadores em se oporem a lei Adolfo Gordo, que determinava a expulsão de militantes operários imigrantes. ${ }^{30}$

Uma das principais resoluções aceitas no primeiro congresso e ratificada nos congressos posteriores era a necessidade de organizar os trabalhadores por ramo industrial. Assim, entendiam que os operários conquistariam maiores vantagens, já que não estariam fragmentados corporativamente na luta contra o capital. Na eventualidade de um agrupamento sindical não conseguir esse objetivo, as bases de acordo da entidade sugeriam a formação temporária de um sindicato de ofícios vários, que seria

Um conjunto de operários de diversos ofícios e profissões que não tenham ainda as respectivas classes organizadas. Sempre que se completa um número de 25 associações de uma só classe, estes se separam para formar seu sindicato autônomo. (A Voz do Trabalhador, 20/7/1914, p.1)

Esse sindicato, além de possibilitar a organização das várias categorias de trabalhadores, teria a função de

Auxiliar a Federação na sua obra de propaganda e abrir as suas portas a todos os operários de boa vontade que nela queiram tomar parte, embora o ofício que exerçam não esteja organizado. (A Voz do Trabalhador, 1/5/1909, p.3)

Nesse sentido, quando uma categoria não conseguisse organizarse como um único grêmio, seja pelo pequeno número de filiados, ou

30 A Lei Adolfo Gordo (lei n.1641 de 7/1/1907) reprimia a presença no país de operários que participassem de greves e agitações. Segundo Batalha (2000), no período entre 1908 e 1921, 556 operários estrangeiros foram expulsos. 
pela pequena expressividade econômica, ela tentaria formar com suas congêneres na mesma situação um único agrupamento operário, com a intenção de fortalecer os laços de solidariedade. Embora possuíssem dificuldades em exigir melhores condições de trabalho e de salários de seus filiados, já que representavam várias categorias de trabalhadores, esses núcleos operários surgiram com a tarefa principal de, nas palavras de Simão (1966)

Reunir o maior número de assalariados, sob qualquer forma de sociedade de resistência [...] Não podia ele, portanto, dispensar a utilização do tipo de grêmio profissionalmente indiferenciado, ante o reduzido número de trabalhadores de distintas categorias ocupacionais, em uma mesma localidade, ou devido à incipiente capacidade associativa do proletariado. (Simão, 1966, p.189)

$\mathrm{Na}$ verdade, muito embora os sindicatos tivessem a sua autonomia, ao estarem ligados organicamente aos princípios da Confederação e de alguma forma submetidos às diretrizes ratificadas nos encontros, surgia uma grande solidariedade entre as entidades para que

a organização do operariado nas associações de classe, unificado, num único ideal, para na mais harmoniosa solidariedade pugnar pela vitória na luta tremenda contra o capital, representado pelo Estado o maior e mais perigoso inimigo da emancipação dos trabalhadores. (A Voz do Trabalhador, 1/1/1913, p.1)

Mas como possibilitar a reunião desses sindicatos num único espírito sindicalista, em um país de dimensões continentais? Uma das formas de comunicação mais rápida daquele momento era o telégrafo. Com mensagens pequenas, as agremiações sindicais conseguiam manter algum contato entre elas.

O principal órgão de centralização dessas informações era o jornal A Voz do Trabalhador. O semanário da Confederação Operária Brasileira funcionava como articulador das entidades de classe e, 
comumente, colocava em seus jornais os envios de telegramas. A partir dessa centralização, as informações eram passadas a todas as entidades filiadas à confederação e, assim, quando ocorresse um movimento grevista, a solidariedade operária era automaticamente recomendada em suas páginas.

Sendo as dificuldades imensas para a organização em nível nacional, esses trabalhadores não mediram esforços para a consecução dessa tão importante (e necessária) tarefa. Para tal êxito, além da centralização das informações telegráficas, a COB enviou militantes de locais mais industrializados (como Rio e São Paulo) para regiões mais distantes, como forma de propagandear suas ideias.

O jornal A Voz do Trabalhador, de janeiro de 1914, relata e conclama os operários à organização e coleta de fundos para as excursões de propaganda e:

Em assuntos gerais travou-se longa discussão sobre vários fatos destacando-se entre estes as excursões de propaganda pelo interior do país. Vários companheiros trataram do assunto, operando-se para que em breve, logo que haja fundos suficientes para tal fim, se encarreguem um ou mais companheiros de seguir para vários pontos e iniciar a propaganda, segundo as deliberações do segundo congresso. (A Voz do Trabalhador, 15/1/1914, p.1)

Em março de 1914, A Voz do Trabalhador noticia a mobilização de operários para uma série de viagens à região Nordeste:

Depois entrou em discussão a resolução do Segundo Congresso sobre as viagens de propaganda por todo o país. [...] Para dar desempenho a esta missão, seguirá o nosso companheiro José Elias da Silva, atual secretário-geral da Federação Operária do Rio de Janeiro, percorrendo os Estados da Baía, Sergipe, Alagoas e Pernambuco. (A Voz do Trabalhador, 1/3/1914, p.1)

O mesmo exemplar anuncia uma provável segunda excursão com a mesma finalidade de angariar novos aderentes à entidade nacional: 
Brevemente seguirá um outro companheiro para os Estados do Sul, com a incumbência de fazer a propaganda acima referida, e é bem possível que ainda este mês siga, com o mesmo intuito, uma comissão para o interior dos Estados do Rio, Minas Gerais e São Paulo. (A Voz do Trabalhador, 1/3/1914, p.1)

As dificuldades de organização eram comuns. Como forma de não gerar custos à entidade-mor, um delegado se prontificou a arcar com as despesas da viagem:

destaca-se a oferta feita pelo companheiro João Crispim, por intermédio do delegado José Borobio, para fazer a propaganda de organização das classes sob as bases da Confederação Operária Brasileira pelos estados que percorrem sem ônus algum para a Confederação. (A Voz do Trabalhador, 1/4/1914, p.1)

Aos poucos os resultados das viagens iam se apresentando no periódico. Em 20/7/1914, o jornal A Voz do Trabalhador apontava o êxito de propaganda do militante João Crispim, no interior de Minas Gerais:

Em Poços de Caldas o resultado de sua excursão foi a fundação da Liga Operária Internacional sob os mesmos princípios e bases da Confederação. (A Voz do Trabalhador, 20/7/1914, p.2)

E o trabalho de propaganda do operário Elias pela região Nordeste do país, segundo o periódico operário, foi satisfatório, já que além de ajudar na fundação de um sindicato, apontava que essas viagens se estenderiam para a região Norte também:

Em Jaboatão, no dia 5 do corrente, fundou-se o Sindicato Operário de Ofícios Vários, com a imediata inscrição de 51 sócios, servindo de fórmula para seus estatutos os da União dos Alfaiates, daqui do Rio. [...] Ao operariado no Norte a Confederação Operária Brasileira aconselha a prosseguir na luta, a fim de que em recente futuro 
possamos assinalar com o mesmo sucesso os feitos dos operários da Baía, Sergipe, Maranhão, Rio Grande do Norte, Piauí, Paraíba, Ceará, e a todos que do norte ao sul do Brasil constituem o braço único, forte, invencível do Trabalho e do Progresso. (A Voz do Trabalhador, 20/7/1914, p.2)

Esses verdadeiros trabalhos de campo sindicais possibilitaram também a reunião de entidades para as quais as distâncias geográficas poderiam criar algum empecilho informacional. As várias resoluções surgidas, a partir dessas viagens, nos mostram as diversas realidades que os sindicatos tiveram que enfrentar no campo organizacional e de que forma elas foram superadas.

Uma das principais questões a se pensar era a pluralidade sindical garantida pelo decreto de 1907. Ao analisarmos vários periódicos operários, percebemos que, mesmo quando ocorria a presença de dois sindicatos de uma mesma categoria, em uma única base territorial, não era incomum as entidades procurarem um acordo. É o que vemos no caso dos padeiros do Rio de Janeiro quando

\section{Sindicato dos Operários Panificadores}

Em assembleia geral realizada no dia 8 do corrente, para resolver sobre a regulamentação do trabalho a seco, ficou resolvido por unanimidade fixar o número em 2 \$ diários, para a manutenção de todos os trabalhadores em padarias, dependendo somente da aprovação da sua coirmã, a liga federal dos empregados em padarias. (A Voz do Trabalhador, 15/2/1914, p.4)

Um fato importante de se analisar ocorreu com a categoria de pedreiros e estucadores. ${ }^{31}$ Vejamos o caso.

\section{Brasil Operário}

Estado do Rio

31 Trabalhadores que trabalham com estuque ou argamassa feita de pó de mármore (Houaiss, 2001). 
Niterói - O sindicato de pedreiros e estucadores de Niterói comunica-nos que tem havido uma grande agitação naquela cidade, e que muitos operários desta capital estão ali trabalhando sem pertencerem àquele sindicato ou ao Sindicato dos estucadores do Rio.

Informa-nos ainda que, para poderem trabalhar é preciso que esses operário apresentem o recibo de sócio quite do Sindicato do Rio, ou caso não estejam ainda associados, filiarem-se a qualquer um dos sindicatos desta capital ou de Niterói. (A Voz do Trabalhador, 15/12/1913, p.3)

Nessa reportagem, o jornal aponta, em primeiro lugar, a força do sindicato de estucadores e pedreiros, pois obrigava os donos de empresa a só aceitarem trabalhadores sindicalizados e quites com a contribuição. Posteriormente, a publicação informa que os sindicatos de pedreiros do Rio e de Niterói propunham que os trabalhadores se sindicalizassem, independente da cidade em que trabalhassem, ou seja, o mais importante era a filiação ao sindicato, ocorrendo uma solidariedade entre ambos, que não disputavam o mesmo trabalhador e sua contribuição.

A análise dos documentos operários permitiu observar, no que tange às relações territoriais dos sindicatos, a presença de uma extensa gama de possibilidades, baseadas livremente em suas necessidades mais urgentes. Nesse sentido, se no primeiro caso houve a possibilidade de dois sindicatos da mesma categoria na mesma cidade chegarem a um acordo, vemos no segundo caso que, às vezes, operários se filiavam aos sindicatos não ligados estritamente à base territorial que a indústria ocupava.

Para os sindicatos dos estucadores, a filiação de trabalhadores não se determinava, necessariamente, pela base territorial do local onde os mesmos exerciam a sua profissão. O mais importante era a filiação, independente se o trabalhador de Niterói o fizesse no sindicato do Rio e o trabalhador do Rio se filiasse ao sindicato de Niterói.

Pelas palavras descritas, a preocupação dos sindicatos estava mais em como organizar os trabalhadores, e não com a perda de recursos econômicos. 
Em algumas cidades, se a indústria ou um tipo industrial tivesse a sua localização espacial mais periférica, era comum que o sindicato seguisse a mesma dinâmica, como forma de desenvolver melhores estratégias de combate ao capital.

Alguns casos merecem uma análise mais detalhada.

No $2^{\circ}$ Congresso Operário realizado em 1913, a criação de sucursais de sindicatos nas áreas mais afastadas foi discutida, surgindo uma resolução acerca do tema.

\section{Segundo Tema}

Conveniência da instalação de sucursais ou seções de sindicatos nas grandes cidades.

Considerando que, nas grandes cidades, os trabalhadores de certas classes encontram-se, devido às grandes distâncias, em condições que os impossibilitem de construírem um só sindicato, concorrendo este fenômeno natural para o pouco desenvolvimento do movimento associativo das mesmas classes.

O congresso aconselha aos sindicatos que estejam em tais condições, concorram para a criação de seções dos mesmos, sem prejuízo da autonomia de cada seção, devendo-se criar, com elementos de todas as seções, uma comissão de relações e propaganda. (A Voz do Trabalhador, 1/10/1913, p.3)

A resolução incentivava que os sindicatos buscassem formas de se organizarem territorialmente com maior dinamismo, preocupando-se única e exclusivamente com as maiores possibilidades de entendimento quando de um movimento paredista. ${ }^{32}$

Um desses sindicatos, filiado à COB, apontava no final de 1914 a formação de algumas sucursais nas áreas arrabaldes, ampliando a base territorial da área central para as áreas mais periféricas.

32 Movimento paredista era como os operários chamavam os movimentos de greve. 
Regulamento da sucursal do Sindicato Operário das Pedreiras. Esta sucursal terá como objetivo as bases do Sindicato dos Operários das Pedreiras.

Art $2^{\circ}$ - Esta sucursal estabelece o seu círculo a todas as pedreiras onde trabalhem cavoqueiros, ferreiros, ajudantes, encunhadores, macaqueiros, canteiros e aprendizes e serventes das mesmas classes.

a) O seu círculo será compreendido nas pedreiras da Cidade Nova e na Zona Suburbana.

[...] Aprovado em assembleia geral realizada em 30 de agosto de 1914, na sede da sucursal, à Rua Barão de Mesquita 944, no Andaraí Grande. (A Voz do Trabalhador, 1/11/1914, p.4)

Essa notícia mostra-nos a preocupação do sindicato em delimitar a base territorial de sua sucursal para as regiões mais periféricas e, de alguma forma, ampliar a presença do sindicato para a cidade como um todo.

Percebemos então que a definição de sua área de atuação passava única e exclusivamente pelas reais necessidades que a entidade tinha de organizar seus filiados e não por qualquer regulamentação externa e, por isso, estranha a essa necessidade.

Outra questão que a notícia nos aponta é a agregação de vários ofícios dos trabalhadores em pedreiras em uma única entidade, evitando uma fragmentação dessa categoria.

Além dessa dinâmica (a criação de sucursais de sindicatos em áreas arrabaldes das grandes cidades como forma de melhor organizar a categoria), a presença de uma indústria ou um tipo de indústria numa área suburbana poderia gerar um sindicato ou uma liga de trabalhadores que teria a sua base territorial semelhante àquela ocupada pela indústria.

É o que vemos nos dois casos a seguir.

Sindicato operário suburbano (Zona da Leopoldina)

$\mathrm{Na}$ última reunião que foi muito concorrida foram tratados diversos assuntos, dentre os quais a nomeação dos delegados junto à federação operária e definitiva instalação da sede, que passará a 
ser doravante num esplendido prédio, à Estrada da Penha (estação de Bonsucesso). (A Voz do Trabalhador, 15/6/1913, p.4)

A Greve de vidreiros de Água Branca (São Paulo) continua firme. Os grevistas estão dispostos a não voltar ao trabalho enquanto (sic) não sejam atendidas suas reclamações.

A liga dos vidreiros de Água Branca declarou a boicotagem aos produtos da fábrica Antárctica. (A Voz do Trabalhador, 30/9/1909, p.3)

No primeiro caso, parece-nos que o surgimento do sindicato deveu-se, principalmente, às dificuldades de comunicação entre a área central da cidade e a sua periferia.

Esse sindicato era filiado à federação operária local e tinha como propósito organizar os trabalhadores das áreas mais longínquas do centro e, por isso, teria a sua base territorial circunscrita a essa parte da cidade.

Ou seja, a sua territorialidade se concretizava numa parte do subúrbio e não em toda a área urbana.

Embora semelhantes em algumas ações territoriais (como se localizar nas áreas afastadas da região central), a liga de vidreiros tinha como base territorial um bairro da cidade de São Paulo que tinha a presença de fábricas de vidros.

Analisando o censo de 1907, sabemos que nesse bairro da cidade (Água Branca) localizava-se a principal empresa de vidros da capital paulista, a Vidraria Santa Marina, com 408 operários e capital de 1.040:000\$000.

A constituição de um sindicato no bairro, e não na cidade toda, pode revelar que a entidade de trabalhadores seguiu a própria organização espacial desse ramo industrial, já que a principal empresa localizava-se nessa região.

Entendemos que, para esses trabalhadores, seguir a base territorial da indústria significaria que o sindicato poderia conquistar maiores benefícios a seus filiados, o que poderia não se concretizar se 
algum preciosismo territorial (como a localização da sede no centro da cidade) ocorresse.

Outro fato que merece consideração refere-se ao apelo da confederação operária e de suas federações para a constituição de sindicatos e/ou ligas em distritos pertencentes a uma cidade, caso da formação de um sindicato na Vila Rafard, então pertencente à cidade de Capivari no Estado de São Paulo. (A Voz do Trabalhador, 15/2/1913)

Uma expressão de territorialidade que ocorria à época era a ampliação da base territorial de um sindicato, de uma cidade para outra cidade vizinha, ou mesmo, a criação de sindicatos em algumas cidades do mesmo estado da federação, promovendo a formação de extensas redes sindicais.

Como forma de melhor demonstrar essa dinâmica, abaixo citamos alguns exemplos.

São Paulo - capital

Continua desenvolvendo enérgica propaganda no seio da classe a União dos Chapeleiros em Geral, contando já elevado número de associados, que diariamente aumenta.

Além disso, existem seções da mesma associação de classe em Campinas, Bragança etc.; e tendo associados em Limeira, Mogi Guaçu, Jaboticabal, Mogi das Cruzes e Taubaté.

A sua sede social acha-se instalada à Rua Formosa, 19, sobrado. (A Voz do Trabalhador, 15/8/1913, p.2)

S.R.T em Trapiches e Café - Inauguração da sucursal em Niterói

Proporcionou verdadeiramente um dia de grande entusiasmo e propaganda das modernas ideias que hão de levar o proletariado à sua integral emancipação, o fato da inauguração a 10 do corrente, na vizinha cidade fluminense, a capital do estado do Rio, da sucursal da Sociedade de Resistência dos trabalhadores em trapiches e café, com sede nesta cidade. [...] É desejo da Resistência estender sucursais por outros estados e com o nobre intuito do mais facilitar e ampliar a luta dos trabalhadores contra o regime da exploração patronal. (A Voz do Trabalhador, 15/8/1913, p.3) 
Os dois casos demonstram claramente a ampliação da base territorial dos sindicatos.

No caso do sindicato dos chapeleiros, ${ }^{33}$ chama a atenção o fato de que havia trabalhadores de algumas cidades associados ao sindicato com sede em São Paulo, capital, visto que a falta de número suficiente de operários impossibilitava a formação de uma sucursal.

Desta forma, quando ocorria um movimento paredista, não apenas suas sucursais espalhadas pelo interior organizavam as atividades de greve, como também os trabalhadores de algumas cidades filiados ao sindicato de São Paulo.

Interessante anotar que a organização dos chapeleiros evoluiu consideravelmente nos anos de 1910, sendo que em 1920 se reuniram em Montevidéu, Uruguai, chapeleiros de vários países da América do Sul, formando o $1^{\circ}$ Congresso da Federação Sul Americana de Chapeleiros.

Um pouco diferente é a organização territorial do sindicato dos trabalhadores em trapiches e café do Rio de Janeiro.

Isso porque a sua base territorial se estendeu de uma cidade (Rio de Janeiro) para outra cidade vizinha (Niterói) ao se criar uma nova sucursal. Desta forma, vislumbra-se a formação de uma mancha territorial compacta entre as cidades, quando a mesma entidade representaria os trabalhadores, diferente do caso anterior, quando essa ampliação territorial era mais difusa.

Esses fatos demonstram que quando ocorria uma greve, todas as sucursais poderiam estar ligadas à organização do movimento, determinado uma ampliação dessas lutas para todas as cidades do Estado que possuíssem sucursais ou trabalhadores filiados.

33 Simão (1966) aponta a existência de outras categorias que criavam sucursais de seus sindicatos pelo interior do estado de São Paulo. Diz: "Não só pela propaganda dos sindicatos caracterizou-se essa fase, mas também pelo processo de articulação das unidades de base em associações de grau superior. Assim, chapeleiros, gráficos, têxteis e ferroviários ensaiaram congregar em uniões gerais os grêmios existentes de suas categorias, assim como trabalharam no sentido de criar novas filiais, segundo a terminologia da época" (Simão, 1966, p.168). 
É importante frisar que o fato de se chamar "união" explicita que houve a reunião de duas entidades sindicais na mesma base territorial, ou seja, dois sindicatos se acordaram e formaram um só grêmio. Esse fato era corriqueiro à época, visto a própria dinâmica sindical (autonomia sindical).

Temos nessa mesma dinâmica o caso da União dos Trabalhadores Gráficos de São Paulo, formada em 1903 da reunião da "Associação das Artes Gráficas e Anexas" com o "Centro Tipográfico Paulistano". 34

Como vários outros sindicatos, imbuídos da solidariedade de classe, a partir da fundação buscavam a criação de filiais por todo o Estado.

Nesta fase de propaganda intensa destacou a União dos Trabalhadores Gráficos várias comissões para o interior e para o litoral do Estado, conseguindo fundar diversas associações gráficas e as Ligas Operárias de Campinas, Jundiaí e Rio Claro. (Pinheiro, 1979, p.153)

E, ao formarem extensas redes de solidariedade, dificultavam a ação patronal na arregimentação de trabalhadores no período de greves.

É o que vemos no caso abaixo

São Paulo - Ribeirão Pires

Nesta cidade estão em greve os operários canteiros, por terem os patrões diminuído o preço da mão de obra em $1 \$ 500$ cada mil paralelepípedos em 10 por cento em outros trabalhos.

[...] A união dos Canteiros daquela localidade apela para que não sigam para ali em substituição dos que estão em greve, para

34 Sobre essas uniões operárias, Simão (1966, p.167) aponta que "os gráficos tinham duas associações no começo do século, que se fundiram em 1904 formando a União dos Trabalhadores Gráficos; dois grêmios de chapeleiros fundiram-se em 1904 constituindo a União dos Chapeleiros". 
assegurar-lhes na vitória. E este justo apelo nós reforçamos, por um dever de solidariedade. (A Voz do Trabalhador, 1/11/1913, p.4)

As greves de solidariedade ${ }^{35}$ existiam, pois a formação dos vários sindicatos e ligas operárias envolvia, às vezes, os mesmos participantes (caso de Edgar Leuenroth, representante da Federação Operária e membro da União dos Trabalhadores Gráficos), mas principalmente, essas entidades tinham a mesma estratégia, algo que em muito facilitava a própria organização do movimento.

É o caso também da União dos Alfaiates do Rio de Janeiro. Fundada em 1913, a entidade participa do $2^{\circ}$ Congresso Operário, filia-se à Federação Operária e à Confederação Nacional, e em seus estatutos deixa claro que não luta apenas pelos seus associados,

Guiados sempre pelo princípio de solidariedade, nós temos sempre acompanhado lado a lado todos os movimentos de nossos companheiros de outras classes, não só desta capital como dos Estados e das outras nações. Não conhecemos posições nem fronteiras e, como tal, onde houver um grito de dor ou um alarme de revolta, lá se tem encontrado a União dos Alfaiates e antes dela existir, as agremiações que a precederam, levando o lenitivo ao sofrimento, ou o apoio incondicional à revolta desde que uma e outra coisa tenham suas causas na desigualdade social. (Pinheiro, 1979, p.146)

Outra questão a ser discutida refere-se à ligação entre sindicatos de estados diferentes. Dependendo da força da categoria, a organização territorial por todo o país era uma realidade.

Um caso de territorialidade ampliada, ou seja, um sindicato de uma região mais distante se filiar ao seu congênere melhor organizado ocorreu em 1920 no Pará, quando a Aliança dos Empregados em Comércio e Indústria filiou-se primeiramente à Federação Estadual carioca, depois à sua congênere do Rio de Janeiro.

35 As greves de solidariedade estão discutidas neste mesmo capítulo. 
Ou seja, como forma de se fortalecer internamente, a entidade dos empregados do comércio se filia não a uma federação de trabalhadores paraense, mas a uma federação estadual mais organizada, nesse caso, a do Rio de Janeiro.

Diz a base de acordos da entidade paraense:

Art. $5^{\circ}$ - A Aliança será filiada à Federação dos Trabalhadores do Rio de Janeiro e à Confederação Operária Brasileira sempre que estejam baseadas no acordo com os fins da aliança e mantenham a mesma orientação de que trata o art. $3^{\circ}$ destas bases.

E explicando os motivos de tal filiação, afirma:

[os trabalhadores] resolveram a fundação da Aliança dos Empregados no Comércio e Indústria do Pará a qual será composta de empregados do comércio e casas industriais e será filiada à Aliança dos Empregados no Comércio e Indústria do Rio de Janeiro, a fim de com esta e outras associações do país fundar a Federação Nacional dos Empregados do Comércio e Indústria. (A Voz do Trabalhador, Pará, 26/6/1920, p.4)

A entidade carioca teve atuação forte nos meios sindicais entre os anos de 1919 e 1921. Chegou a possuir mais de mil sócios (em uma categoria de quase 80 mil pessoas) e ao contrário de algumas congêneres se limitava a ter apenas trabalhadores, quando era comum a presença de empresários em outras entidades.

Desta forma, a entidade paraense, ao se filiar a uma entidade estadual que não era de seu estado de origem, procurava estreitar laços e, principalmente, formar uma rede de sindicatos, tanto com a congênere carioca como com a federação carioca, permitindo assim que as entidades sindicais mais distantes das áreas industrializadas conseguissem algum tipo de ação conjunta, muito embora as distâncias geográficas pudessem funcionar com um empecilho na organização operária. 
Outro exemplo é o da Associação de Marinheiros e Remadores, com sede no Rio, mas com atuação em todo o país.

No dia 23 de outubro esta associação comemorou o seu nono aniversário de fundação empossando a nova diretoria, que terminará o seu mandato em igual data de 1914.

Essa associação conta com 7.000 agremiados e mantém várias sucursais nos diversos portos do Brasil [...] e saiu vitoriosa em vários movimentos efetuados no estado do Rio Grande do Sul, e embora não confederada, tem sempre agido diretamente sem recorrer a elementos políticos estranhos à classe. (A Voz do Trabalhador, 01/11/1913, p.4)

A Associação de Marinheiros e Remadores aos poucos ia ampliando a sua base territorial, da cidade do Rio de Janeiro para outras capitais litorâneas. Essa ampliação possibilitaria a formação de um amplo movimento de luta no país.

A força dessa entidade é demonstrada pela grande organização territorial (ampliação da base territorial local para nacional), sua perenidade (surgiu em 1904 e finda apenas em 1930), sendo que manteve, conforme Batalha (2009), uma média de 2 mil sócios no período que vai de 1912 a 1916.

Isso significa, para nós, que essas agremiações, ainda que embasadas em princípios federativos, ligavam-se às suas coirmãs de forma orgânica, mesmo que existisse entre elas grande independência.

Outra forma de relacionamento entre os sindicatos foram as federações operárias. Poderiam ser locais ou estaduais.

Tinham como propósito

Estabelecer o comum acordo entre todos os sindicatos de ofícios vários, ou federações de ofícios, [...] auxiliar todo e qualquer sindicato, federação de classe ou ofícios vários, quando os mesmos necessitem promover a solidariedade entre todas as associações federadas e a fundação de outras que ainda não estejam constituídas. (Carone, 1984, p.410) 
Era comum a presença de federações locais em cidades com grande presença operária, as quais aglutinavam importantes parcelas de trabalhadores na luta cotidiana contra a exploração do trabalho.

Em alguns casos percebemos, inclusive, a presença de duas federações de operários numa mesma cidade, sem que necessariamente competissem entre si.

Um dos principais exemplos foi a cidade de Santos, que até meados da década de 1920 possuía duas federações de trabalhadores, a Sociedade Internacional União dos Operários e a Federação Operária de Santos.

Quando se realizava um evento de grande expressividade na cidade, eventualmente ocorria a participação ativa de ambas as entidades na organização dos trabalhadores.

Na greve das Docas, em novembro de 1908, foi relatado que

O movimento foi declarado no dia 09 de setembro pelos sócios da Internacional, composto de carroceiros e operários das Docas. Estes reclamavam o horário de 8 horas, e os carroceiros declaram que foram à greve por solidariedade. [...] Deu-se então um facto grandioso e pouco vulgar nas lutas proletárias contra o capital. Os operários pertencentes à Federação (e todo o operariado de Santos) sem prévio acordo, sem reuniões, como uma só pessoa, declararam-se em greve, sem outro fim que o de prestar a solidariedade aos companheiros de luta. (A Voz do Trabalhador, 29/11/1908, p.2)

Da mesma forma, quando o número de agremiações em um estado exigia a formação de uma rede sólida e organizada, criava-se a federação estadual.

Algumas delas surgiam restritas a uma cidade, e posteriormente aumentavam a sua base territorial. Esses foram os casos da FORGS (Federação Operária do Rio Grande do Sul) e da FOA (Federação Operária de Alagoas).

\section{Fundação da Federação Operária}

Por uma ocasião reuniram-se alguns operários e deliberaram fundar a Federação Operária do Rio Grande do Sul, a fim de 
agrupar as diversas associações existentes na capital e futuramente estender a sua ação a todo o Estado. (A Voz do Trabalhador, 15/1/1914, p.3)

\section{Alagoas}

A Federação Operária, segundo informações transmitidas para esta capital, criou um jornal para a defesa da mesma e do operariado alagoano.

O movimento operário, até então circunscrito em Maceió, estende-se atualmente ao interior e para qual muito só tem esforçado os elementos da Federação com a publicação do novo jornal, muito lucrará a organização trabalhadora desse Estado. (A Voz do Trabalhador, 01/1/1913, p.4)

Esses dois exemplos demonstram a ampliação da base territorial dessas federações. Eram locais e, posteriormente, com a agregação de sindicatos do interior, estavam presentes em quase todo o estado, sendo um importante elemento de organização.

Mesmo tendo grande autonomia na federação, os sindicatos congregados deveriam manter o firme propósito de luta contra o capital e o Estado, como também estar preparados para o chamado de um movimento mais amplo.

Como apontava o jornal A Plebe,

As primeiras organizações operárias no Brasil foram por certo as ligas operárias que reuniam quase sempre indistintamente os operários de diversos ofícios e indústrias. [...] São uniões de ofícios que ao se desenvolverem fundam pelo país sucursais e filiais, diretamente dependentes da central estabelecida na grande cidade. (A Plebe, 01/4/1922, p.1)

As declarações do semanário paulistano não deixam dúvidas acerca das principais tarefas de organização dessas federações: autonomia e solidariedade. 
Autonomia para que o sindicato tivesse liberdade de organizar os seus filiados e não sofrer qualquer ingerência que pudesse prejudicar suas lutas. E solidariedade, pois, um sindicato, uma liga, não conseguiriam, individualmente, promover grandes derrotas ao patronato.

Esse espírito de solidariedade possibilitava que algum sindicato federado mais organizado e, portanto, mais coeso na luta contra o capital, também tivesse contatos com o exterior, como forma de dificultar a ação das empresas.

Foi o que ocorreu com o sindicato dos canteiros do Rio de Janeiro e a ação conjunta com seu congênere de Buenos Aires.

Ultimamente o Sindicato dos Canteiros publicou um manifesto reclamando a solidariedade de todos os trabalhadores em pedra, para evitar que os patrões de São Paulo e Buenos Aires, onde há greves de canteiros, consigam contratar operários nesta capital com o fim de fazer fracassar o movimento. (A Voz do Trabalhador, $17 / 4 / 1909$, p.4)

Nessa notícia, apesar de não mostrar uma territorialidade como descrita anteriormente, é nítida a presença de um relacionamento internacional entre as entidades.

Entendemos que o contato entre as entidades de São Paulo e Buenos Aires demonstra uma intensa sintonia internacional.

Interessante anotar que essa relação internacional não ficava circunscrita apenas ao relacionamento entre confederações nacionais, mas também entre sindicatos, federações e ligas operárias.

Entretanto, por ser a organização-mater dos sindicatos, à $\mathrm{COB}$ caberia a maior parte do contato com o exterior.

Analisando o jornal A Voz do Trabalhador, detectamos inúmeras situações nas quais o internacionalismo estava presente, como o apoio a greves, participação de estrangeiros em encontros nacionais, participação de brasileiros em encontros internacionais, para citar os principais fatos. 
Adiante, apresentaremos algumas passagens do jornal citado acima, como forma de melhor compreender esses contatos.

Realizou-se em Londres, de 27 de setembro à 2 de outubro, o Primeiro Congresso Sindicalista Internacional. Estiveram representados os seguintes países: Inglaterra, França, Itália, Suécia, Alemanha, Áustria, Holanda, Bélgica, Espanha, Estados Unidos, Argentina, Cuba e Brasil.

O delegado da Confederação Operária Brasileira foi o camarada Guy Bowmai. (A Voz do Trabalhador, 15/11/1913, p.2)

\section{O delegado das organizações platinas}

Tomando em conta o comitê da Confederação Operária Brasileira, a Federación Obrera Regional Argentina e a Federación Obrera Regional Uruguaya enviaram a esta capital o companheiro José Borabio, aqui chegado no dia 09, a bordo do "Cap. Ortegal".

O delegado daquelas duas possantes organizações foi recebido, pelos congressistas, com uma entusiástica e carinhosa manifestação de simpatia, tomando assento entre os mesmos. (A Voz do Trabalhador, 01/10/1913, p.2)

Em nota da atitude reacionária do governo, a Confederação Operária Brasileira, há cerca de seis meses, enviou um delegado à Espanha e Portugal para recomendar aos trabalhadores daqueles países não emigrarem para o Brasil enquanto não fosse revogada a lei especial de expulsão. A julgar pelos relatórios recebidos de Portugal, o delegado da COB teve um brilhante sucesso. (A Voz do Trabalhador, 15/11/1913, p.2)

Os três fatos apresentados demonstram uma certa pluralidade nas relações entre os sindicatos na esfera internacional. A primeira citação aponta uma ligação estreita entre a COB e outras centrais sindicalistas-revolucionárias, principalmente da Europa. Demonstra que não só a C.G.T francesa era uma parceira da entidade, como 
também aponta uma tentativa de fortalecimento dessas agremiações de perfil sindicalista pelo mundo.

A segunda citação, datada de outubro de 1913, refere-se à ligação entre as confederações sul-americanas. No $2^{\circ}$ Congresso Operário Brasileiro, participou como ouvinte um representante operário da região platina, a saber, Uruguai e Argentina, numa tentativa de criar laços mais fortes entre as entidades.

Sobre a última citação, entendemos que a $\mathrm{COB}$, conforme as condições financeiras, sempre enviava um representante seu para a Europa com o objetivo de alargar a rede de solidariedade internacional, ou mesmo combater no exterior a promulgação de leis antioperárias e imigrantes no Brasil.

As três citações do jornal A Voz do Trabalhador demonstram as dificuldades de comunicação, exigindo que os operários buscassem formas de manter contato com o estrangeiro. Nessa análise inicial, apontamos e discutimos a presença de diversas formas de territorialidades e relacionamentos entre os sindicatos, ligas, federações e confederação, explicitando, de alguma maneira, um movimento sindical de expressividade no país. Essas territorialidades discutidas acima se concretizaram por três motivos principais: primeiramente, a própria dinâmica de organização dos sindicatos, de caráter horizontal e federalista, propiciou grande autonomia às entidades de classe.

Em segundo lugar, as distâncias geográficas aliadas à própria dificuldade de manutenção dessas agremiações, seja pela falta de recursos econômicos, seja pelo assédio do Estado que culminava, não raramente, com o próprio fechamento do sindicato, exigiam que a busca de parcerias fosse inevitável, principalmente daquelas que estavam em regiões distantes da área mais industrializada.

E, por fim, ainda que pouco influente se comparado com os motivos anteriores, não podemos esquecer que a legislação sindical que regia esse período permitia uma ampla relação interterritorial.

Muito embora não tivessem como objetivo a apropriação de um território específico, as ações operárias configuram-se numa ten- 
tativa dos trabalhadores em criar uma rede solidária pelo território nacional.

Essa rede, arquitetada pelos congressos operários, permitia a formação de um elo de defesa contra as investidas patronais e do Estado, mas não só.

Ao se formarem essas ligações territoriais, os sindicatos criavam também a possibilidade de se construir um modelo cotidiano divergente do predominante burguês.

Isso porque a presença de sindicatos e a sua constante tentativa de aglutinação propiciavam a presença de extensas redes culturais, econômicas e educacionais, como o teatro operário, o baile operário e, também, as chamadas Escolas Modernas, núcleos de educação dos trabalhadores para os trabalhadores.

Graças aos sindicatos e às suas territorialidades, por exemplo, núcleos de educação social surgiram em vários estados brasileiros, sendo que Hardman (1982) afirma a presença de 25 estabelecimentos nas cidades de São Paulo, Rio de Janeiro, Niterói, Petrópolis, Belém, Recife e Porto Alegre.

Esses núcleos educacionais, a presença de centros de cultura com palestras sobre a questão social, a exibição de peças de teatro retratando o cotidiano operário contribuíram para a existência de um sindicalismo de resistência e de grande dinamismo.

Alguns eventos ocorridos nesse período só foram possíveis pela presença de uma forte organização sindical.

Foi o que aconteceu na Greve Geral de 1917 em São Paulo. Embora surgisse limitada a uma categoria (têxtil), o movimento paredista logo alastrou-se pela cidade, tendo ocorrido greves de solidariedade ao movimento em várias localidades do Estado (Campinas, Sorocaba, Jundiaí), no Rio de Janeiro, em Curitiba e em áreas mais afastadas foram notadas manifestações de solidariedade, como em Recife, Manaus e Belém (Lopreato, 2000).

Moreira (1985) comenta que as greves gerais que ocorreram no período de 1917 a 1920

demonstram certa maturidade do movimento operário brasileiro, visto que já se organizava nacionalmente e sob uma única orienta- 
ção, acompanhando dessa forma a dinâmica da economia fabril, que outrora regionalizada, aos poucos ia se tornando nacional. (Moreira, 1985, p.80)

Por fim, ocorreu em 1920 o III Congresso Operário Brasileiro, no Rio de Janeiro, resultado das grandes agitações acontecidas no período de 1917 a 1919. Esse encontro contou com a participação de 150 delegados, representando 75 associações sindicais de vários estados.

Tabela 3 - Entidades participantes do $3^{\circ}$ congresso operário brasileiro

\begin{tabular}{lll}
\hline Estado & Cidade & Entidades \\
\hline $\begin{array}{l}\text { Antigo } \\
\text { Distrito }\end{array}$ & Rio de Janeiro & Aliança dos Operários em Calçados \\
& & \\
& Rio de Janeiro & $\begin{array}{l}\text { Associação dos Trabalhadores em } \\
\text { Marcenaria }\end{array}$ \\
& Rio de Janeiro & $\begin{array}{l}\text { Associação dos Empregados do } \\
\text { Comércio e Indústria }\end{array}$ \\
& Rio de Janeiro & Associação dos Trabalhadores em \\
& Carrinho de Mão \\
& Rio de Janeiro & Associação Gráfica do Rio de \\
& Janeiro \\
& Rio de Janeiro & União Geral dos Metalúrgicos \\
Rio de Janeiro & União Operária de Tinturarias \\
Rio de Janeiro & União dos Chapeleiros \\
Rio de Janeiro & União Operária da Construção Civil \\
Rio de Janeiro & Sindicato Culinário \\
Rio de Janeiro & União Operária de Fábrica de \\
& Tecidos \\
Rio de Janeiro & Associação dos Malheiros e Artes \\
& Correlativas \\
Rio de Janeiro & União Operária dos Vassoureiros \\
Rio de Janeiro & União de Empregados em Fábricas \\
& de Bebidas \\
\hline &
\end{tabular}




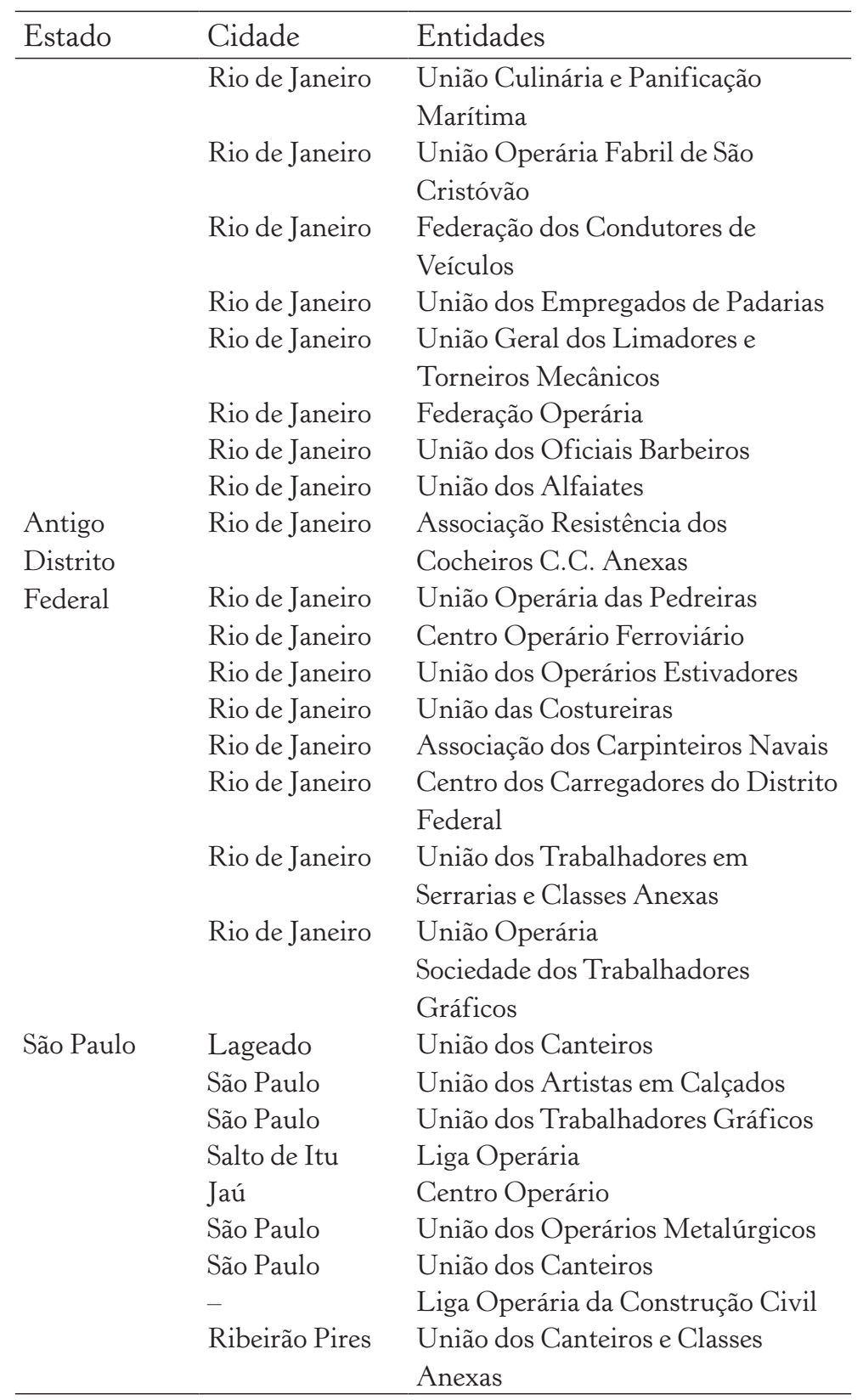




\begin{tabular}{|c|c|c|}
\hline Estado & Cidade & Entidades \\
\hline & São Paulo & $\begin{array}{l}\text { União Operária em Fábrica de } \\
\text { Tecidos }\end{array}$ \\
\hline & São Paulo & Liga dos Manipuladores de Pão \\
\hline & São Paulo & União dos Alfaiates \\
\hline & São Paulo & Federação Operária \\
\hline & Santos & Sindicato dos Canteiros \\
\hline & - & Associação Gráfica Fluminense \\
\hline \multirow[t]{5}{*}{ Minas Gerais } & Elói Mendes & União dos Operários \\
\hline & - & Associação Beneficente Irmãos \\
\hline & & Artistas \\
\hline & Juiz de Fora & Federação Operária Mineira \\
\hline & Cataguases & Liga Operária \\
\hline \multirow{6}{*}{$\begin{array}{l}\text { Rio Grande } \\
\text { do Sul } \\
\text { Pernambuco }\end{array}$} & Porto Alegre & Federação Operária \\
\hline & Porto Alegre & Sindicato dos Canteiros \\
\hline & Recife & Sindicato dos Alfaiates \\
\hline & - & $\begin{array}{l}\text { Associação dos Sapateiros e Classes } \\
\text { Anexas }\end{array}$ \\
\hline & Recife & União Geral da Construção Civil \\
\hline & Recife & $\begin{array}{l}\text { Liga Mista de Resistência dos Oper. } \\
\text { Em Fáb. De Cigarros }\end{array}$ \\
\hline \multirow[t]{3}{*}{ Paraná } & Curitiba & União Ferroviária \\
\hline & Curitiba & $\begin{array}{l}\text { Internacional Operária de Southern } \\
\text { Brazilian Railway }\end{array}$ \\
\hline & Curitiba & Sindicato da Construção Civil \\
\hline \multirow[t]{2}{*}{ Pará } & Belém & Sindicato União dos Carpinteiros \\
\hline & & Navais e Calafates \\
\hline Amazonas & Manaus & Assoc. Construção Civil \\
\hline Rio de Janeiro & Niterói & Liga Operária da Construção Civil \\
\hline
\end{tabular}

(Org. Amir El Hakim de Paula apud Rodrigues, 1979)

Ao contrário dos encontros anteriores (primeiro e segundo congressos), a tabela 3 demonstra a presença de entidades em várias cidades do país, demonstrando, de certa forma, os efeitos das várias excursões de propaganda, como também um maior espraiamento da indústria nacional. 
Abaixo, o mapa 1 ilustra a participação de cada estado, em número de entidades presentes, nos três congressos operários (1906, 1913 e 1920).

\section{Entidades Participantes dos Congressos Operários}

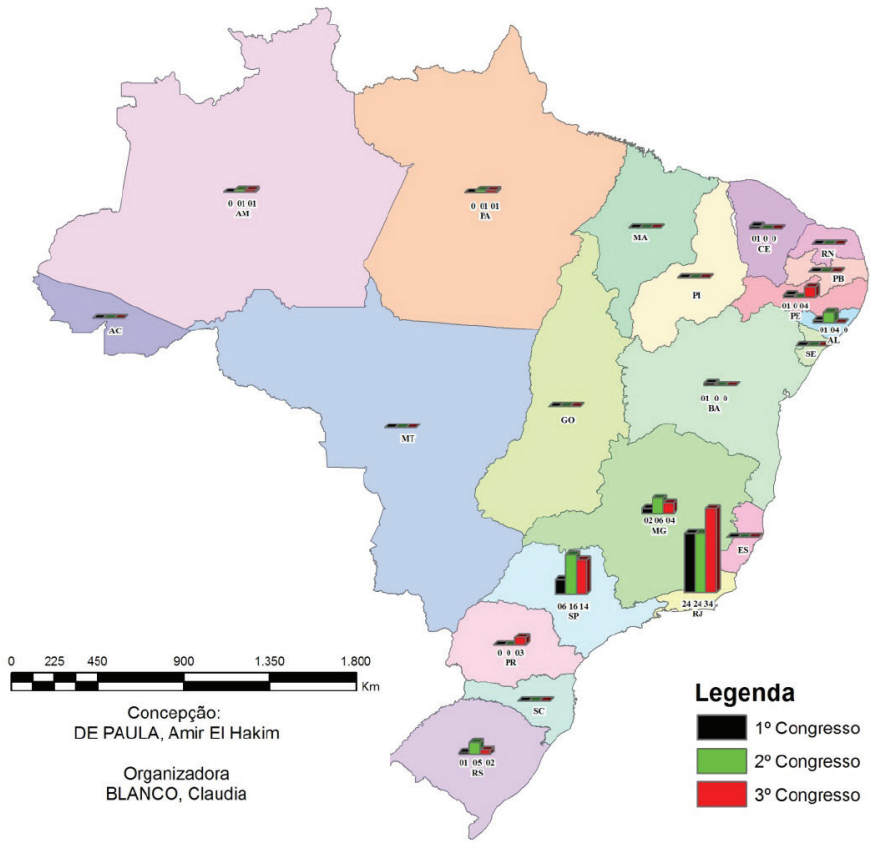

Mapa 1 - Fonte: A Voz do Trabalhador (1908-1915); Pinheiro (1979).

Além de destacar, pela própria predominância industrial, a maciça participação nos encontros de entidades do Rio de Janeiro e de São Paulo, o mapa 1 demonstra que, mesmo em números bem inferiores, o movimento sindical revolucionário já tinha presença em todas as regiões do país, seja em áreas mais próximas aos grandes centros, como Paraná e Minas Gerais, ou em áreas mais distantes, como o Amazonas, o Pará e boa parte da região Nordeste, como comentado anteriormente. 
No Congresso Operário de 1920, a questão principal discutida foi a reorganização dos sindicatos-revolucionários, tendo em vista a falta de uma central sindical nacional e que o período de 1917-1919 tinha mostrado a esses sindicalistas a necessidade de ampliação dessas ideias pelo país.

Foram, então, incentivadores, as excursões pelo país, o crescimento da presença sindical e de suas lutas e a necessidade de uma maior aglutinação para o enfrentamento do capital.

Ao contrário dos encontros anteriores, já era claro uma maior centralização das ações, embora a autonomia sindical continuasse preservada.

Como forma de coordenar as ações dos trabalhadores nas cidades, de maneira que sua autonomia não fosse desrespeitada, os operários resolveram "dividir" o país em cinco grandes regiões.

Essa divisão regional também foi necessária pelas distâncias de alguns sindicatos do interior do país com relação aos centros industriais mais prósperos.

Ao realizarem essa regionalização, os sindicatos almejavam criar redes de solidariedade pelo país, apontando uma cidade-sede, que centralizaria as informações sindicais funcionando como um polo de concentração das atividades de organização e propaganda.

Essa divisão regional caracterizava-se também pela total liberdade territorial, visto os critérios adotados serem econômicos, de afinidades, de proximidade com a cidade-sede, ou seja, predominavam nessa regionalização aspectos socioeconômicos. ${ }^{36}$

A comissão executiva do $3^{\circ}$ congresso se subdividirá em 5 seções: extremo norte, com sede em Belém, compreendendo os estados de Amazonas, Pará, Maranhão, Ceará, Piauí e Acre; norte, com sede no Recife, compreendendo os Estados do Rio Grande do Norte,

36 Segundo o IBGE, a primeira divisão regional do Brasil foi feita em 1913 por Delgado de Carvalho, tendo por base os elementos do meio físico e a posição geográfica. Mais detalhes, acessar a página: <http://74.125.95.132/search?q=cache:sPvzz3eYhrVJ.www.ibge.gov.br/home/estatistica/populacao/censo2000>. Acesso em: 16/2/2011. 
Paraíba, Pernambuco, Alagoas, Sergipe e Bahia; centro, com sede no Rio, compreendendo o Distrito federal, os estados do Rio, Espírito Santo e Minas (menos as duas zonas do Sul e do Triângulo); sul, com sede em São Paulo, compreendendo os Estados de São Paulo, Goiás, Mato Grosso e as duas zonas do Triângulo e Sul de Minas; extremo-sul, com sede em Porto Alegre, compreendendo os Estados do Paraná, Santa Catharina e Rio Grande do Sul. (Boletim da Comissão Executiva..., 1920)

\section{Organização Regional do $3^{\circ}$ Congresso Operário}

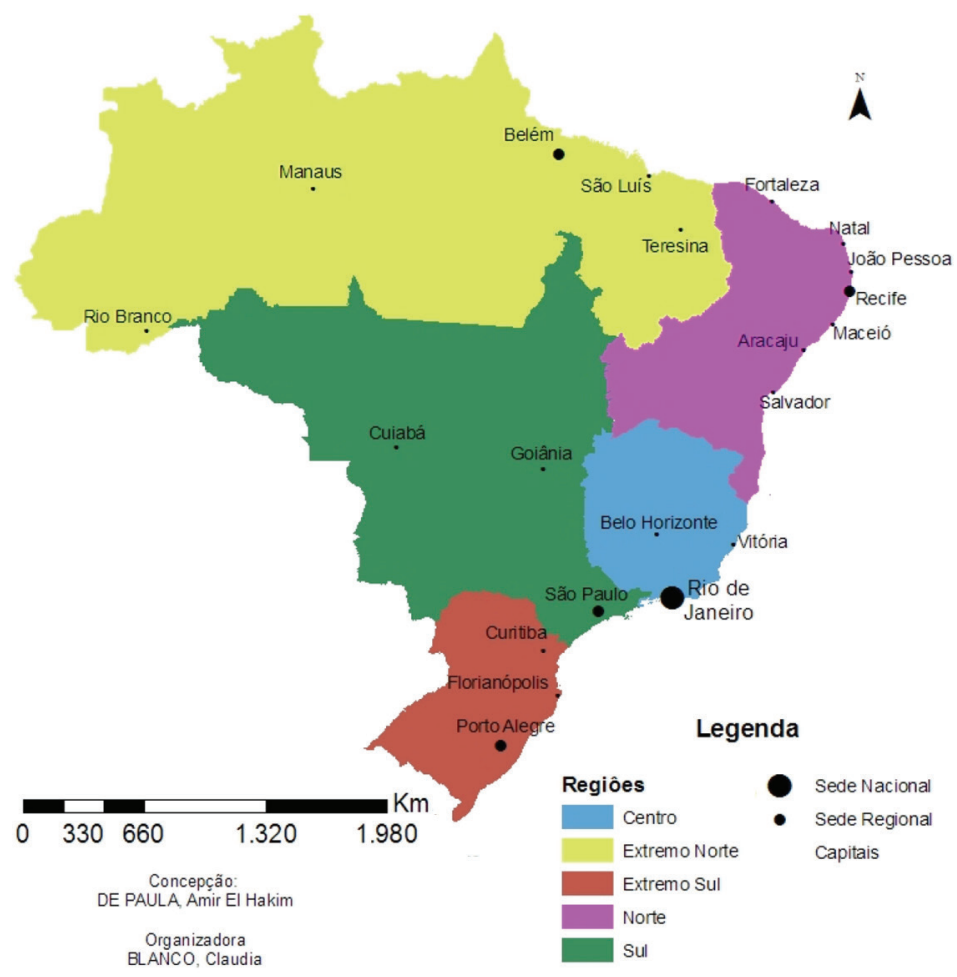

Mapa 2 - Fonte: Boletim da Comissão Executiva do $3^{\circ}$ Congresso.

O mapa 2 revela quais eram as áreas de influências das cidadessedes do encontro. Nele podemos perceber a força da cidade do Rio 
de Janeiro com os traços mais fortes, demonstrando a coordenação geral do encontro, e os traços com espessura menor, demonstrando as áreas de influências das outras sedes regionais.

O fato interessante é que Belém tem grande influência na atual Região Norte do país, mas também em alguns estados da atual Região Nordeste, por ter um importante porto de exportação e de cabotagem.

\section{Reelaboração da Demonstração Gráfica da Organização da Comissão Executiva do $3^{\circ}$ Congresso}

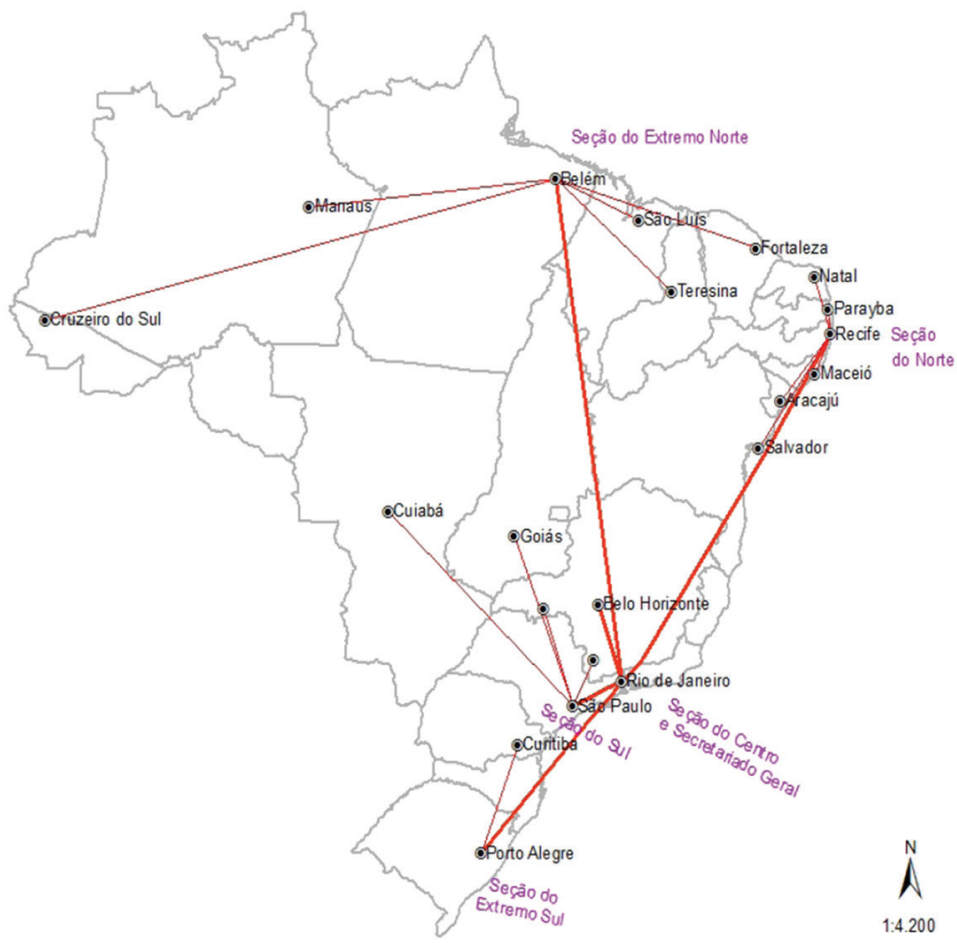

Mapa 3 - Fonte: Boletim da Comissão Executiva do $3^{\circ}$ Congresso Operário.

Sobre a divisão regional do mapa 3, duas considerações são pertinentes. 
Na primeira, percebemos o sucesso dessas excursões, seja na ampliação no número de sindicatos pelo interior do país, claramente demonstrada pela organização do $3^{\circ}$ congresso, ou nas greves gerais ocorridas em 1917 e 1919.

Sobre essa organização pelo país, Dulles (1977), ao comentar o $3^{\circ}$ Congresso Operário, aponta os encarregados de cada seção regional. Nelas, vemos a participação dos vários militantes destacados em 1914 para o trabalho de propaganda. Diz:

No $3^{\circ} \mathrm{COB}$, a divisão geográfica dava-se, que o Rio de Janeiro seria a sede de um 'secretariado geral', compreendendo um secretário-geral (Edgar Leuenroth), tesoureiro e com secretários itinerantes, responsáveis pelas cinco regiões geográficas em que se dividira o país. Os secretários itinerantes eram: Domingos Passos (Centro), José Elias da Silva (Norte), Jorge Adalberto de Jesus (Extremo Norte), Teófilo Ferreira (Sul) e Alberto Torres (Extremo Sul). (Dulles, 1977, p.116)

O segundo fato leva-nos a algumas hipóteses acerca da fragmentação do estado de Minas Gerais em três regiões, com sedes regionais distintas.

A princípio nossa pesquisa entendeu que a divisão do estado mineiro levava em consideração apenas a sua extensão territorial. Entretanto, ao aprofundarmos essa questão, encontramos outro fator demonstrando que apenas a extensão não explicaria totalmente essa divisão.

Segundo Dias (1977, p.286), a Liga Operária de Poços de Caldas, como vimos anteriormente, tinha sido fundada em 1913 por meio das excursões de propaganda, e era filiada à Federação Operária de São Paulo, em que pese estar localizada em Minas Gerais. ${ }^{37}$

37 Batalha (2000, p.34) informa a existência de uma Federação Operária Mineira, com sede em Juiz de Fora, apenas na década de 1920. Entretanto, essa entidade expressava ideais reformistas e não postulados sindicalistas-revolucionários. 
A partir desses dados, iniciamos uma análise acerca da formação econômica dessas duas regiões mineiras, como forma de compreender uma possível ligação com o estado de São Paulo.

Nesse sentido, nossa pesquisa voltou-se para o entendimento da presença ou não de indústrias no estado de Minas Gerais e qual a ligação dessa região, principalmente, com o estado de São Paulo.

A análise realizada acerca da gênese industrial mineira demonstrou que a maior parte dessas indústrias localizava-se na Zona da Mata,

Ou seja, na principal região cafeeira do estado que se desenvolveu, até aproximadamente 1930, o seu principal núcleo industrial (sobretudo no município de Juiz de Fora), que os mineiros orgulhosamente chamaram de "Manchester Mineira". (Lima, 1981, p.57)

Em que pese essa maior concentração industrial na Zona da Mata, outras áreas tinham presença de indústrias, principalmente têxtil. No período em estudo, Ribeiro de Oliveira (1996) aponta que existiam indústrias desse ramo no Triângulo Mineiro (cidade de Uberaba) e no Sul (cidades de Machado, Lavras e São João Del Rey).

Com essas informações, percebemos que as regiões tinham boas ligações de transportes com São Paulo e por isso sofriam deste estado grande influência.

Assim, nossa hipótese é que os sindicatos da região tinham relações de maior interesse com seus congêneres paulistas, visto o estreito relacionamento econômico entre as regiões citadas e o estado de São Paulo. ${ }^{38}$

38 Singer (1974), ao analisar o café em Minas Gerais, alertava que "o desenvolvimento da cafeicultura no sul e no Triângulo se dá em função de São Paulo, do mesmo modo que o da zona da mata se deu em função do Rio. Na medida, portanto, em que no fim do século passado crescia a produção de café no sul e no triângulo, este se escoava por Santos, através do sistema ferroviário paulista, e toda essa área se ligava, de modo cada vez mais estreito, à economia de São Paulo" (Singer, 1974, p.213). 
Ao estudarem o poder dos estados no início do século XX, Love et al. (1982) apontaram a forte atração entre a elite mineira e o estado de São Paulo.

Com essa intensa relação entre essas elites, "o polo de crescimento paulista fazia do Triângulo e do Sul de Minas parte natural do mercado de São Paulo, a que essas duas zonas estavam ligadas por boas comunicações" (Love et al.,1982, p.82).

Ou seja, a ligação econômica entre as regiões mineiras e o estado de São Paulo de certa forma justificaria um maior interesse entre os sindicatos da região e os paulistas, demonstrando que não faria sentido para essas entidades seguir estritamente a divisão administrativa oficial, visto que tal amarração dificultaria uma maior integração do movimento operário.

O terceiro encontro nacional, de certa forma, foi o ápice de um forte movimento grevista iniciado em 1917 e continuado em 1919. A estruturação federalista de funcionamento da COB (Confederação Operária Brasileira) no período, a necessidade de superação dos obstáculos criados pela extensão territorial, que, de alguma forma, dificultava a organização das entidades sindicais distantes dos grandes centros, propiciaram a presença de variadas relações interterritoriais entre os sindicatos.

Essas relações interterritoriais dos sindicatos, baseadas em um acordo mútuo de solidariedade operária e em pressupostos federalistas, possibilitaram que algumas amplas greves ocorressem, abarcando diferentes setores econômicos, e ficando conhecidas como "greve de solidariedade".

\section{3 - As greves de solidariedade e a questão territorial}

Um das facetas principais do movimento operário desse período foram as greves de solidariedade. Baseadas num entendimento de que a classe operária era única e por isso deveriam ser superadas as diferenças corporativas, esses movimentos ocorriam em apoio a uma 
categoria específica, independente da relação econômica que poderia esta ter com a classe como um todo. ${ }^{39}$

Alguns desses movimentos grevistas, dependendo da importância social que a categoria poderia ter, recebiam o apoio de outros setores da sociedade, como os pequenos comerciantes. Mais do que uma questão social, para nós, esses movimentos mostram outra faceta possível pela organização horizontalizada: a formação de redes territoriais de solidariedade, ou seja, a organização e a ação do movimento paredista ultrapassavam as fronteiras municipais, estaduais e, mais raramente, as fronteiras nacionais. ${ }^{40}$

Uma mostra dessa união operária era evidenciada pela presença da palavra "internacional" no nome. Como exemplos existiam a Associação Internacional União dos Operários - Santos ou, mesmo, no caso de uma categoria específica, a União Internacional dos Canteiros de Ribeirão Pires. Como demonstra Simão,

Tal filiação foi às vezes expressa no próprio título do grêmio que incluía o termo internacional e outras vezes era declarada nos próprios estatutos, como fez a União dos Trabalhadores Gráficos, que se ligava às suas respectivas uniões, nacional e internacional. (Simão, 1966, p.178)

Ligados de alguma forma, seja ideologicamente ou corporativamente, os sindicatos nesse período procuravam vários meios de conseguir os seus objetivos, e a greve de solidariedade aparecia como uma estratégia de enorme eficácia. Algumas delas, por serem de grande repercussão à época, mas principalmente pelo seu caráter

39 Uma das resoluções do $1^{\circ}$ Congresso Operário Brasileiro dizia que "o desenvolvimento da indústria faz-se no sentido de exigir de todos os trabalhadores, sem distinção de oficios, uma solidariedade cada vez mais estreita, tendendo a abolir as barreiras que separam as corporações de ofícios".

40 Foi o que vimos no caso do Sindicato dos Canteiros de Buenos Aires, solicitando o apoio do sindicato paulista para evitar a saída de trabalhadores para aquela cidade e assim dificultar o movimento paredista. 
espacial, serão tratadas aqui: a Greve dos Ferroviários de 1906 e a Greve Geral de 1917.

\subsubsection{A greve dos ferroviários de 1906 e a questão territorial}

As análises territoriais de uma greve, ou mesmo de uma passeata, são ou deveriam ser também objeto da Geografia.

Entretanto, poucos foram os geógrafos que tiveram a preocupação em compreender as ações territoriais desses movimentos.

Ao analisar alguns dos periódicos da época, como por exemplo, A Voz do Trabalhador, órgão da Confederação Operária Brasileira, percebemos em suas páginas, comumente, a informação acerca das greves ocorridas.

Algo que nos chamava a atenção enquanto destacávamos alguns desses movimentos era a presença de solidariedade entre os grevistas da categoria parada com os outros trabalhadores.

Nas páginas do semanário $A$ Voz do Trabalhador era comum aparecerem notícias sobre as várias greves, entretanto, aquelas que conseguiam superar o espírito corporativo e buscavam a solidariedade de classe eram extremamente comemoradas.

Um movimento que teve grande repercussão na classe operária foi a Greve dos Ferroviários da Companhia Paulista. Em abril de 1906, os sindicatos-revolucionários se reuniram no Rio de Janeiro e inúmeras resoluções foram discutidas e referendadas. E em maio do mesmo ano era realizada a que seria, até então, a maior greve no Estado de São Paulo, tendo 15 dias de duração.

A greve dos Ferroviários, que teve como área de atuação principal a Companhia Paulista de Estrada de Ferro, foi deflagrada pela Liga Operária de Jundiaí em 15 de maio e, já nas primeiras horas da manhã, graças ao uso do telégrafo, segundo Leme, "abrangendo as mais diferentes cidades do interior do Estado, num total de $1057 \mathrm{~km}$ ao longo de 119 estações" (Leme, 1986, p.77). 
A Companhia Paulista tinha sido formada pela elite cafeicultora em 1868, com a intenção de deslocar mais rapidamente seus produtos do interior para o porto de Santos, sendo o primeiro trecho construído entre Jundiaí e Campinas.

A partir de 1870, vários prolongamentos ocorrem com a intenção de interiorizar cada vez mais a estrada de ferro. Em 1873 foi determinado seu prolongamento até Rio Claro, área de grande produção cafeeira. Em 1881 chegava até a cidade de Descalvado, passando por cidades importantes como Araras e Pirassununga.

Nas décadas de 1880 e 1890, a Companhia Paulista resolveu expandir o traçado da ferrovia com o prolongamento de Rio Claro a São Carlos (1884), de São Carlos a Araraquara (1885), e o ramal de Visconde do Rio Claro a Jaú (1887). A partir dessa data, com a incorporação da The Rio Claro São Paulo Railway Company, ampliou-se a malha ferroviária da Companhia Paulista até Jaboticabal (1893), ocorrendo outro prolongamento somente no início do século XX, quando a ferrovia atinge as cidades de Bebedouro e Barretos. ${ }^{41}$

Para a estudiosa da greve, o movimento se iniciou na cidade de Jundiaí e, de lá, a greve se espalhou, como um rastilho de pólvora, para todas as cidades abrangidas pela malha ferroviária da Companhia Paulista, como Campinas, Vila Americana, Limeira, Cordeiro, Araras, Pirassununga, Porto Ferreira, Descalvado, Rio Claro, Anápolis, São Carlos do Pinhal, Guariba, Jaboticabal, Bebedouro e pelos ramais de Santa Veridiana, Santa Gertrudes, Campo Alegre, Brotas, Torrinha, Dois Córregos, Santa Eudóxia, Ribeirão Bonito, Jaú, Pederneiras, São Paulo dos Agudos, Piratininga, Guatapará, Pontal e Santa Rita (Leme, 1986).

Uma das características dessa greve foi que as reivindicações dos trabalhadores não estavam assentadas apenas em questões salariais (como se poderia imaginar), mas na exigência da demissão de um

41 Para um maior detalhamento da história da Companhia Paulista de Estrada de Ferro, consultar Leme (1986). 
chefe da empresa, ou, nas palavras de Hardman (1982, p.339), "em solidariedade a um companheiro removido arbitrariamente”.

O movimento paredista foi logo apoiado pela Federação Operária de São Paulo, participando, inclusive, Edgar Leuenroth, secretário da FOSP, em várias manifestações. O interessante nessa greve é que, conforme os dias passavam, a intransigência da empresa aumentava, o que criava uma situação de confronto contínuo entre operários e a polícia.

Apesar de a ferrovia ser uma forma de transporte das mais importantes, naquele início do século XX, a que efetivamente transportava as riquezas do país, a população, em geral, em vez de se contrapor ao movimento, juntou-se ao mesmo e várias greves de solidariedade começaram a surgir, envolvendo, inclusive, outras categorias de trabalhadores. Como aponta Leme (1986)

Em São Paulo, a fábrica de calçados Global aderiu à greve, em solidariedade. Em Jundiaí, o mesmo ocorreu com as oficinas da Arens cujos aprendizes destruíram seus equipamentos, enquanto a fábrica de tecidos São Bento, em greve desde o dia 10 de maio, permaneceu no movimento. (Leme, 1986, p.138)

Interessante notar que a greve de ferroviários lentamente vai se transformando em uma greve geral, envolvendo outras categorias de trabalhadores (como os têxteis) e suas várias ligas operárias. Mais do que isso, a greve amplia-se territorialmente, abarcando cidades do estado de São Paulo e de estados vizinhos (como Minas Gerais e Rio de Janeiro).

Funcionários da Estrada de Ferro Mogiana, bem como da Estrada de Ferro Leopoldina e Central do Brasil, também paralisaram e, baseada em um espírito internacionalista, soube-se que até a Liga Operária de Buenos Aires foi solidária ao movimento, colaborando com o envio de recursos financeiros (Leme, 1986).

Independente do alcance territorial das manifestações de solidariedade, a verdade é que o movimento ganhou enormes proporções, sendo que comerciantes de várias cidades (como Jundiaí e Campinas) e estudantes da Faculdade de Direito de São Paulo também aderi- 
ram; os primeiros fechando seus estabelecimentos e os segundos com a organização de um encontro questionando as arbitrariedades realizadas pela polícia.

A presença de trabalhadores na paralisação foi de tal ordem que Hardman (1982) aponta que no dia 26 de maio, em comício liderado pela Federação Operária, compareceram 6 mil trabalhadores no Largo São Francisco, em São Paulo.

Como afirma Hardmann (1982) sobre os impactos da greve

As repercussões do conflito, fora do estado, foram enormes: de São Paulo, a greve generalizou-se, passou às cidades do interior do estado, para, repercutindo como um eco, chegar à capital da República e daí Petrópolis, Porto Alegre e outras cidades e vilas, sendo que nesta última cidade, a greve foi geral, atingindo o setor de transportes. [...] Além disso, a atuação dos organismos sindicais operários, orientados pelas lideranças anarcossindicalistas, demonstrou, na prática, as reais possibilidades e limites do método da ação direta. (Hardmann, 1982, p.340)

Embora o movimento tenha se fortalecido durante o mês de maio, o extenso período de paralisação começou a levar intranquilidade às cidades no que tange ao abastecimento, o que levou a um arrefecimento do movimento.

Outros fatores determinantes à queda de popularidade da greve geral foram as informações desencontradas sobre o evento (alguns jornais comentavam que o movimento já perdia a força, enquanto a federação operária reclamava o contrário) e a intensa repressão policial aos órgãos operários, fazendo que várias ligas e, até mesmo, a federação operária tivessem suas sedes fechadas.

E, então, no final de maio, o movimento se encerra em um comício em Jundiaí, depois de contabilizar a morte de dois trabalhadores pela polícia, sem necessariamente ter conquistado o objetivo inicial. Em que pese o resultado não satisfatório, a greve teve um componente pouco discutido: a evolução territorial do movimento. Para se entender esse processo, levaremos em consideração um fator 
essencial: a presença das ligas operárias. As ligas operárias surgiram no início do século XX no país, fruto das ideias federalistas presentes nos sindicatos-revolucionários, e tinham como objetivo canalizar as várias demandas sociais dos trabalhadores a elas filiados.

Essas ligas tinham a presença de várias entidades de trabalhadores, e de alguns grêmios, inclusive, que teriam grandes dificuldades para organizar-se corporativamente.

No movimento grevista que retratamos anteriormente, é notória a participação das ligas operárias. Embora autônomas, as ligas funcionaram como catalisadoras das demandas dos ferroviários, que embora tivessem uma associação própria (a Sociedade Beneficente dos Operários, ligada à Companhia Paulista), resolveram se utilizar de outros meios para conquistar as suas exigências.

Essas ligas operárias eram uniões de grêmios e por isso alcançavam várias categorias de trabalhadores na área de sua ação. $\mathrm{O}$ interessante nesse aspecto é que, ao terem as mesmas diretrizes sindicais, inclusive ideologicamente sendo similares, quando um movimento grevista surgia, o necessário socorro era direcionado, visto que uma das resoluções do primeiro congresso operário referia-se à união de toda a classe operária.

Mas de que forma essa articulação ocorria? Analisando os trabalhos de Hardman (1982), Simão (1966) e Leme (1986), percebemos que dois fatores foram primordiais para a expansão do movimento: o primeiro se refere à comunicação: as ligas operárias, por meio de seus filiados, se utilizavam do telégrafo para avisar as outras localidades acerca da greve e, posteriormente, de boletins e jornais. Em segundo lugar, havia uma enorme afinidade entre as ligas operárias e a Federação Operária de São Paulo, o que propiciava uma ação conjunta.

Com relação à comunicação, fica evidente que, à época, os trabalhadores se utilizavam dos mesmos meios de comunicação que o patronato, o que possibilitava uma resposta imediata. Por isso, não era raro, e nessa greve isso ocorreu também, que a polícia, a serviço dos patrões (é preciso lembra que Conselheiro Antonio Prado, grande cafeicultor, era o presidente da Companhia Pau- 
lista), fechasse a sede dos jornais e proibisse o uso do telégrafo pelos operários. ${ }^{42}$

Mesmo assim, a força da informação não esmorecia, ao ponto de Leme (1986) apontar que no período mais forte da greve

A liga [de Jundiaí] distribuiu 10.000 destes manifestos ao longo da linha, nos quais os grevistas enumeraram as causas da greve, a partir dos descontentamentos [...]. (Leme, 1986, p.88)

A questão que fica pendente é como a articulação entre as ligas operárias era realizada dentro de uma área territorial extensa? ${ }^{43}$ Para tentarmos discutir essa questão, teremos que relembrar a ideia básica que os unia: solidariedade e federalismo. No primeiro caso, já discutimos e demonstramos de que forma essa solidariedade era ampliada, envolvendo diversas categorias de trabalhadores.

No segundo, é importante ressaltar que o federalismo operário tinha uma base filosófica diferente daquela praticada pelo Estado liberal. Suas ideias estavam ligadas às proposições federalistas discutidas por Proudhon no século XIX e que tiveram grande influência no movimento operário francês.

Posteriormente, outros anarquistas, como Bakunin, iriam se utilizar dessas premissas para propor uma auto-organização dos trabalhadores, ou seja, os trabalhadores de forma autônoma constituiriam as suas entidades, e o federalismo funcionaria como um elo de solidariedade.

42 Diz Leme (1986) que, no auge da greve geral, alguns atos de violência policial foram comuns, entre eles: "interrupção e censura do telégrafo nacional e da Paulista, impedindo a transmissão de notícias sobre a greve e telegramas cifrados [...]" (Leme, 1986, p.119).

43 Segundo o jornal O Estado de S. Paulo (19/5/1906 apud Leme (1986, p.78): "Pela primeira vez os campineiros assistem ao espetáculo de uma greve levada a cabo, é justo reconhecer com a máxima habilidade, pelas muitas centenas de operários e mais empregados da CPEF em todas as suas extensas linhas (mais de $1.000 \mathrm{~km}$ ) desde Jundiaí até as mais longínquas estações no interior do Estado”. 
No nosso caso, a entidade que funcionava como um elo das ligas operárias era a Federação Operária. ${ }^{44}$ Simão (1966), ao comentar o processo de criação das federações estaduais e regionais, no início do século XX, afirma que

Em nível mais alto, surgiram as primeiras federações sindicais de âmbito estadual ou regional. Em 1905 foi criada a Federação Operária de São Paulo, com a finalidade de articular todas as associações de grau inferior, inclusive as uniões gerais. [...] A ela estiveram filiadas quase todas as ligas e uniões gerais localizadas na capital e algumas no interior do Estado. (Simão, 1966, p.168)

A Federação Operária de São Paulo, com sede na cidade de São Paulo, aos poucos vai expandindo a sua área de influência, e as ligas municipais de várias cidades interioranas a ela se filiam.

Toledo (2009), analisando a vida de um dos principais militantes da entidade, Giulio Sorelli, fornece-nos pista sobre a ação da FOSP na articulação das entidades sindicais pelo estado de São Paulo. Diz a historiadora: "O jornal da FOSP anunciava também os horários das reuniões dos vários sindicatos e ligas da capital e do interior" (Toledo, 2009, p.292). Tendo a sede da FOSP como um local de reuniões operárias, a articulação das agremiações era facilitada e a solidariedade num movimento grevista era factível. Relacionando as entidades participantes do movimento de apoio aos ferroviários, Toledo (2009) afirma que

Para a greve da Paulista, por exemplo, contribuíram o jornal socialista Avanti, a União dos Gráficos, a União dos Trabalhadores

44 Com relação à opção pelo federalismo, Samis (2004) afirma que a escolha desse princípio devia-se a que "outro ponto importante era que o federalismo, que facultava aos sindicatos autonomia dentro da federação e, por sua vez, da federação frente à confederação. Situação que favoreceu imensamente a pactuação de grupos sindicais que, se não eram claramente vinculados à proposta anarquista, simpatizavam com os princípios descentralizados da organização proposta" (Samis, 2004, p.135). 
em Veículos, a União dos Chapeleiros, operários e militantes, sobretudo da capital, mas também de Araraquara, Lençóis, Ribeirão Preto, Bauru, Jaboticabal, Limeira, Sorocaba, Pirassununga, Santa Cruz das Palmeiras etc. (Toledo, 2009, p.293)

O esforço de solidariedade é apresentado também pelos gastos e contribuições que a FOSP declarou no mês de maio de 1907. Nesse mês, entraram no caixa 2 contos e 220 mil-réis, sendo que os gastos para a articulação da greve de solidariedade chegaram à quantia de 2 contos, 169 mil e 700 réis, 600 mil réis a mais do que os gastos com despesas de manutenção da entidade, como aluguel da sede.

Essas ações da FOSP possibilitaram que as ligas operárias tivessem um elo entre elas e as outras entidades de classe, fato que permitiu a expansão do movimento por toda a ferrovia. A greve foi iniciada pelas ligas operárias de Jundiaí, Campinas e Rio Claro, expandindo-se para outras cidades onde a ferrovia passava.

Se analisarmos o mapa 4, que mostra os ramais da Companhia Paulista, veremos que as três cidades estavam nas principais passagens da estrada de ferro. Mesmo não sendo grandes entroncamentos da ferrovia, percebemos que, por serem rota dos principais entroncamentos, a paralisação dificultaria o prosseguimento de qualquer carga para a cidade de São Paulo. Ao declararem a greve, logo foi solicitada a colaboração da Federação Operária de São Paulo, por ser um maior agrupamento e, consequentemente, ter as condições mais necessárias para aglutinar os diversos setores de trabalhadores.

Nesse processo, embora a autonomia estivesse preservada, foi comum as ações serem realizadas em conjunto, e então, a luta de uma corporação passava a ser a luta de todos. ${ }^{45}$ Não é de se estranhar então que Edgar Leuenroth, então uma das principais lideranças da Federação Operária, estivesse diretamente envolvido com o movimento. Sobre isso, diz Leme (1986), ao informar o discurso do primeiro dia de manifestações em Jundiaí:

45 Outro movimento que também demonstra uma greve corporativa se transformar em uma greve geral ocorreu em 1907 em São Paulo. 


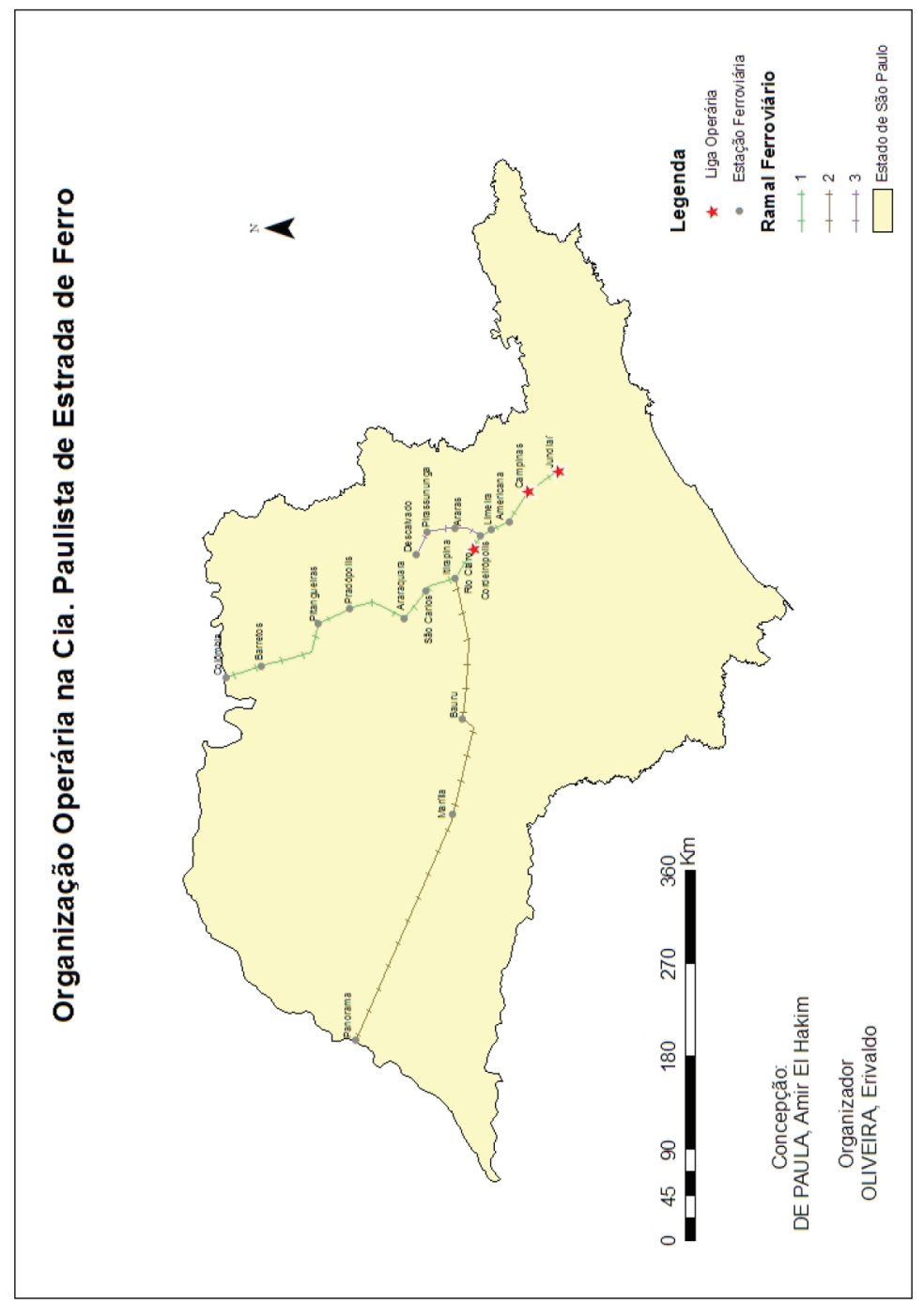

Mapa 4 - Fonte: Leme (1986), Simão (1966), Hardman (1982).

Pisani [principal líder entre os ferroviários] pediu que os companheiros se fiscalizassem mutuamente, aconselhando a solidariedade. Divulgou o apoio recebido de toda a nação e leu os telegramas 
de adesão da Federação Operária, ali representada pelo operário Edgar Leuenroth. (Leme, 1986, p.137)

A presença de Leuenroth demonstra a possibilidade de expansão do movimento pelo interior, além das fronteiras estaduais (devido à própria ligação da Federação com outras entidades nacionais e internacionais). ${ }^{46} \mathrm{O}$ que percebemos nesse movimento é que a intensa relação entre as ligas e a Federação Operária possibilitaram que a greve tivesse uma maior expansão territorial e conseguisse chegar a vários rincões nos quais a Cia Paulista tinha sede. De certa forma, a territorialidade da greve seguiu a mesma territorialidade da ferrovia, mas sobretudo tinha seus principais núcleos em cidades que estavam nas rotas necessárias para a passagem de cargas que tivessem como destino a cidade de São Paulo, e de lá para o porto de Santos. ${ }^{47}$

Essa pequena análise leva-nos a outra percepção: quando a classe operária se une e as desavenças corporativas são deixadas de lado, consegue-se, minimamente que seja, ter controle sobre as ações patronais no território. Nas próximas páginas, nossa análise avança um pouco no tempo e discute territorialmente como se constituiu o que a historiografia brasileira chama de Greve Geral de 1917.

\subsubsection{A greve geral de 1917 sob uma perspectiva geográfica}

A greve se iniciou em 22 de junho no Cotonifício Crespi, quando os operários não tiveram atendidas as suas reivindicações, como o

46 Comentando afirmação da polícia sobre a Greve Geral, diz Toledo (2009): “A polícia de São Paulo associa diretamente essa greve unicamente à ação dos anarquistas, como se observa, por exemplo, neste comentário sobre Edgar Leuenroth: 'Em maio de 1907, teve papel saliente na grande greve da qual foi um dos promotores. Essa greve foi trabalho dos anarquistas de São Paulo e envolveu as indústrias da capital e a Companhia Paulista de Estrada de Ferro"”' (Toledo, 2009, p.308).

47 O percurso ferroviário da cidade de Jundiaí para a cidade de Santos era realizado pela São Paulo Railway. 
aumento de salários e fim do trabalho noturno. O movimento então se estendeu a outras fábricas com as mesmas reclamações e, com reclamações específicas a cada uma, totalizando no início de julho mais de 20 mil operários paralisados, quando então já eram várias as categorias e as fábricas paradas, sendo grevistas de vários setores, tais como canteiros, leiteiros, oleiros etc. (De Paula, 2005).

Desde o seu início, a greve teve como forma de ação a apropriação dos espaços da cidade, primeiramente nos bairros industriais e de moradia operária, para que, aos poucos, os trabalhadores conseguissem chegar ao centro da cidade, principal local das manifestações públicas do movimento. A greve, conforme ganhava expressividade, começou a sofrer o ataque da Força Pública e, então, conflitos entre operários e policiais tornaram-se intensos.

A reportagem do jornal Correio Paulistano, órgão do Partido Republicano Paulista e representante dos interesses da elite paulista, demonstra essa ocupação territorial, com certo temor:

Com o decorrer das horas, o movimento pelas ruas do bairro, e especialmente pela grande artéria que é a avenida Rangel Pestana, começou a intensificar-se e era quase na sua totalidade composto de operários, homens, mulheres e crianças que haviam deixado de comparecer às fábricas. De uma certa hora em diante, o triângulo central entregue a sua atividade pacífica começou igualmente a ser invadido por uma onda de desocupados. O comércio, alarmado com os gritos subversivos que partiam daqui e acolá, julgou prudente cerrar também as suas portas, a exemplo do que estava sucedendo nos arrabaldes, ainda os mais longínquos. (Correio Paulistano, 13/7/1917, p.2)

Mais do que uma ocupação da cidade, a Greve de 1917 teve a particularidade de se expandir territorialmente para outras cidades do estado, como também de receber movimentos de apoio em outras cidades do país. Como vimos no caso da greve dos ferroviários, a Greve de 1917 em São Paulo, muito estudada por cientistas sociais e historiadores, pouca atenção recebeu dos geógrafos no que tange às 
estratégias territoriais que o movimento teve para que se mantivesse coeso por vários dias, em que pese a constante repressão policial, com prisões, empastelamentos de seus jornais e fechamento das sedes das entidades operárias.

Como aponta Lopreato (2000) sobre a geografia da greve

Os ecos da Greve Geral de julho de 1917 chegaram além das fronteiras paulistas. No Rio de Janeiro, Curitiba e Porto Alegre, o elemento detonador dos movimentos grevistas nessas cidades de forte tradição de luta anarquista foi a manifestação de solidariedade operária aos companheiros de São Paulo. A exemplo do que ocorreu na capital paulista, foram os libertários a incentivarem o operariado das três importantes capitais do país a paralisar suas atividades e lutar por um melhor viver. As cidades de Salvador, Recife, João Pessoa, Belém e Manaus, assim como as cidades mineiras de Itajubá e Belo Horizonte, também foram palco de manifestações operárias. Gigi Damiani, um dos membros do CDP [Comitê de Defesa Proletária, órgão que organizou o movimento], chegou a afirmar que uma nova página da história poderia ter sido escrita no Brasil se todos os movimentos grevistas que eclodiram nos vários cantos do país tivessem ocorrido ao mesmo tempo. (Lopreato, 2000, p.129-130)

Coordenado pelas ligas operárias de bairros, o movimento se expandia para cidades nas quais a existência de ligas operárias, com intensa relação com as congêneres paulistanas, ocorria. Como afirma Lopreato (2000),

No interior do estado de São Paulo, ferroviários em Campinas e tecelões em Sorocaba e Jundiaí, encorajados pelo êxito obtido pelo operariado paulistano, entraram em greve em 16 de julho de 1917 por aumento de salários e melhores condições de trabalho. A exemplo dos paulistanos percorreram as ruas centrais da cidade e realizaram comícios em praças públicas. A solidariedade manifestada pelos trabalhadores de diferentes categorias levou 
à generalização do movimento nas três cidades [...]. (Lopreato, 2000, p.130)

Como na análise anterior, a questão principal para nós é entender de que forma um movimento local se expande para várias cidades do estado e, posteriormente, para grandes cidades de outros estados da federação. Um ponto essencial para essa análise é compreender a ligação estreita que as ligas operárias propiciavam aos sindicatos e sua relação com instâncias maiores, como as Federações Operárias. As ligas operárias, surgidas em São Paulo, tiveram como objetivo melhorar as condições de vida e de trabalho dos trabalhadores das várias categorias. Ao organizarem os trabalhadores num único agrupamento,

a luta por melhorias objetivava manter acesa a chama da coesão, através da participação conjunta dos seus membros em movimentos de combate aos açambarcadores e falsificadores de alimentos [...] exigir dos patrões e dos chefes em geral urbanidade e respeito para com os trabalhadores, assim como condições mínimas de segurança, de higiene e de conforto para evitar acidentes e as moléstias do ambiente de trabalho. (Lopreato, 2000, p.100-101)

A importância delas no movimento grevista é incontestável: foi a partir dessas organizações que a greve foi se movimentando das periferias para o centro da cidade, ou seja, o movimento se expandia territorialmente pela cidade, conforme a organização das ligas operárias nos bairros. ${ }^{48}$ Entretanto, o que mais impressiona nesse movimento é a sua expansão para áreas longínquas, como cidades no Sul e no Nordeste do país.

Ainda que tivessem específicas exigências das categorias paradas, os operários dessas cidades se espelhavam nas agitações

48 Conforme De Paula (2005) demonstrou, as ligas operárias de bairro constituíamse geograficamente em todas as áreas da cidade, da Lapa ao Belenzinho, no eixo oeste-leste, e de Santana ao Ipiranga, no eixo norte-sul. 
paulistas e, principalmente, se solidarizavam com elas. Algumas manchetes de jornais operários ilustram essa situação

O Movimento tomou grandes proporções. O esplêndido movimento paulista repercutiu fundamente (sic) nesse marasmo carioca, retesando energias adormecidas, afiando vontades amolentadas e reacendendo entusiasmos apagados. (A Plebe, 28/7/1917, p.2)

Um dos principais papéis na articulação das paralisações coube à Federação Operária do Rio de Janeiro. ${ }^{49}$ Por meio de telegramas, esse núcleo de entidades procurou centralizar as informações do movimento paulista e coordenar, a partir de sua sede, um movimento de expansão de greves de solidariedade por várias áreas do país.

No dia 14 [de Julho] realizou-se a reunião convocada pela Federação Operária do Rio de Janeiro para deliberar sobre a atitude que o operariado daquela capital deveria tomar diante da greve geral de S. Paulo. [...] Foi aprovada a seguinte moção: [...] completa solidariedade ao operariado de São Paulo, ora, em greve [...] Resolve ainda telegrafar a todas as associações federadas dos Estados, para que as mesmas procedam de acordo com o movimento iniciado no estado de São Paulo. (A Plebe, 21/7/1917, p.4)

49 Embora Batalha (2005) afirme, como vimos, que a Confederação Operária Brasileira (COB) já não mais existisse em 1917, reportagem do jornal A Plebe, do dia 1/9/1917, informava a intenção de se construir um congresso operário em outubro daquele ano, sendo que o papel de coordenação caberia à entidade nacional. Diz um trecho: "Nesta capital [Rio] também se realizará brevemente uma grande reunião onde se deverão fazer representar todas as associações, centros, grupos etc. que estão de acordo com a organização desse congresso. É bom notar que todas as federações sindicalistas dos diversos estados do Brasil são confederadas à COB”. Sendo a Federação Operária ou mesmo a COB, o importante é perceber que a expansão do movimento teve uma articulação a partir da cidade do Rio de Janeiro, sede da principal representante do movimento sindical à época e também dos congressos operários anteriores (1906 e 1913). 
Analisando os vários números do semanário operário A Plebe, principal órgão de divulgação das atividades operárias, percebemos a expansão da greve por várias cidades do país. No Paraná, por exemplo,

Como se viu, o movimento grevista de São Paulo teve grande repercussão não só no interior como em outros estados. No Paraná, a greve assumiu enormes proporções. Em Curitiba paralisou toda a vida da cidade [...] Em Ponta Grossa também teve grande importância. (A Plebe, 28/7/1917, p.3)

E continua, com várias manchetes

O operário gaúcho começa a agitar-se [...]. Em Paraíba, várias corporações declaram-se em greve. Em Poços de Caldas, demonstração de solidariedade da Liga Operária Internacional. (A Plebe, 4/8/1917)

As páginas do jornal nos revelam que o movimento de solidariedade se alastrava pelo país, sendo comum o envio de telegramas comunicando o início de um movimento grevista.

Analisando os mapas 5 e 6, percebemos que o movimento vai se irradiando da cidade de São Paulo para as cidades vizinhas e depois para as cidades mais distantes do estado paulista. ${ }^{50}$ Esse fenômeno foi possível graças à articulação das ligas operárias municipais (como a de Jundiaí e de Campinas) com as Federações Operárias carioca e paulista, sendo que esta última já tinha um papel de articulação na expansão da greve pela capital paulista.

É por isso que no período de 9 de julho até 17 de julho várias cidades tiveram greves gerais (como Campinas) ou mesmo movimentos de trabalhadores exigindo melhores salários ou condições de

50 Resolvemos dividir as manifestações conforme o mês de surgimento, sendo primeiro mês (junho), segundo mês (julho) e terceiro mês (agosto). Todos os dados foram coletados do jornal A Plebe e de Lopreato (2000). 
trabalho (caso de Sorocaba). Conforme a greve aumentava na cidade de São Paulo, e já era visível sua expansão pelo Estado, começava uma segunda articulação de sindicatos, agora coordenada pela $\mathrm{Fe}$ deração Operária do Rio de Janeiro, que procurava arregimentar greves de solidariedade por todo o país.

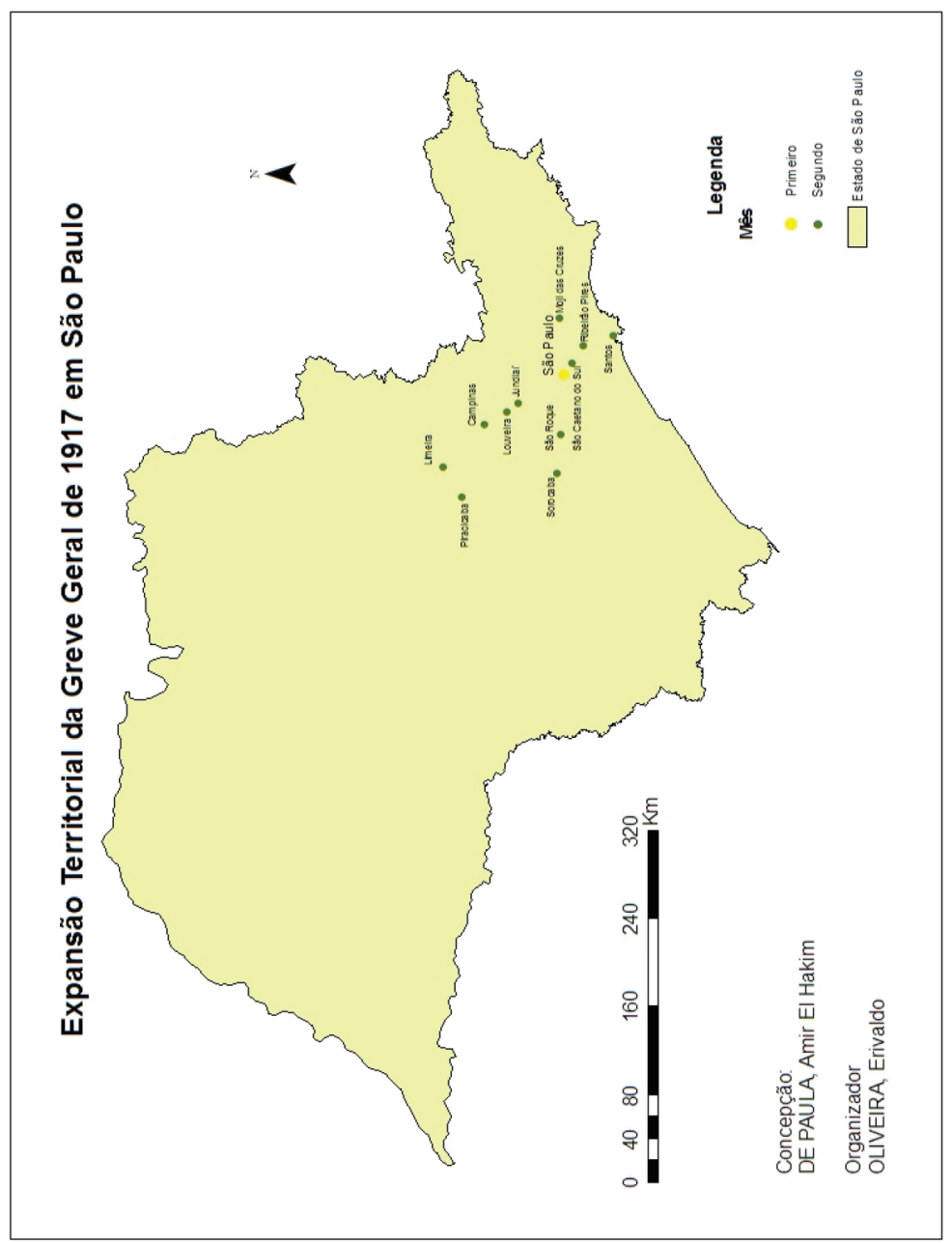

Mapa 5. 


\section{ExpansãoTerritorial da Greve Geral de 1917 no Brasil}

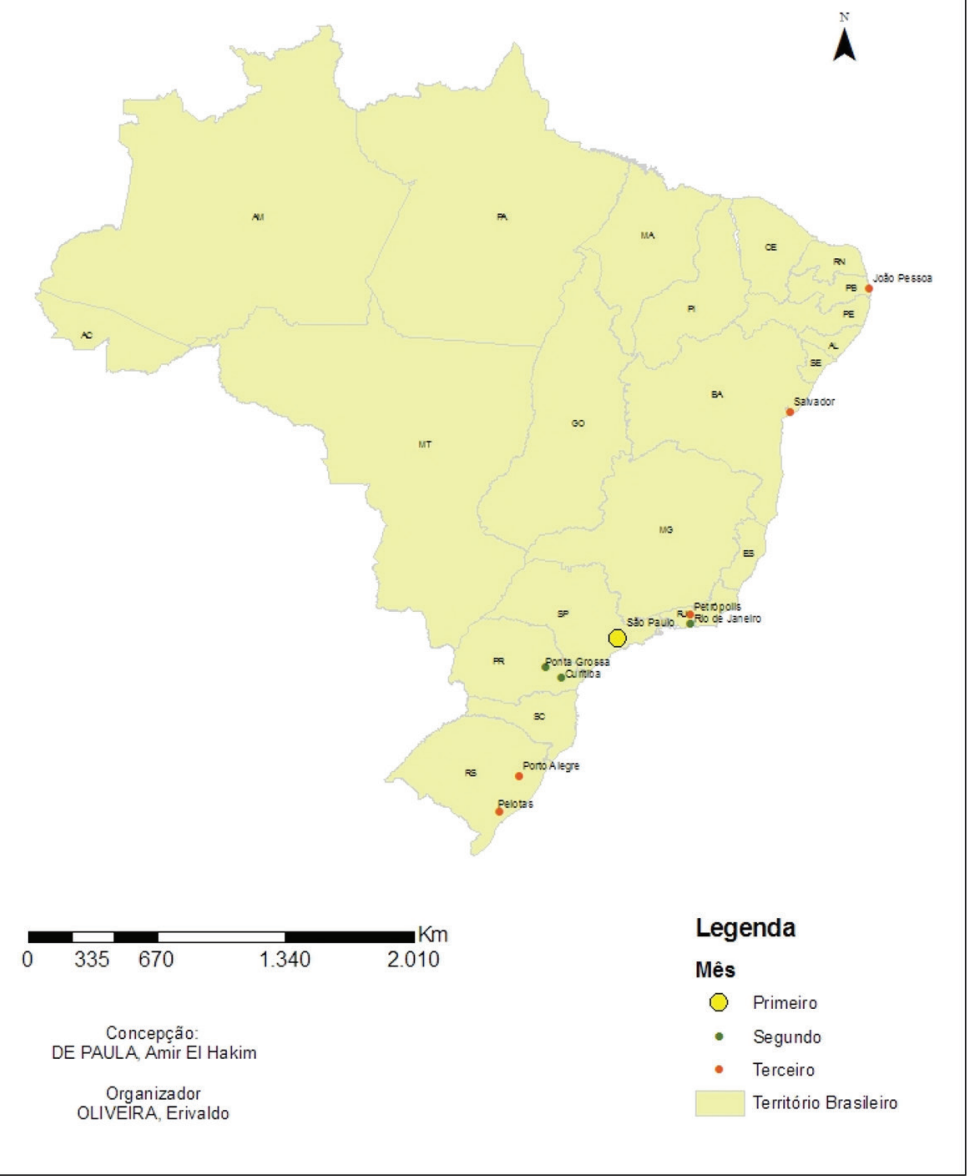

Mapa 6 - Fonte dos mapas 5 e 6: Lopreato (2000) e A Plebe (1917).

Nesse caso, as paralisações ocorreram, principalmente, no período de 28 de julho a 11 de agosto, quando cidades mais longínquas, como cidade da Paraíba (atual João Pessoa), passariam também por greves de categorias, como vemos no mapa 5 sobre a expansão da greve no Brasil. Para compreendermos essa expansão territorial 
nacional, é importante recordarmos também as várias expedições realizadas no ano de 1914 para algumas áreas do país, como forma de organizar os sindicatos dentro de uma visão sindicalista-revolucionária.

Ao realizarem essas expedições, os operários criavam um laço de solidariedade entre os sindicatos, que posteriormente facilitaria a emergência de uma paralisação maior. ${ }^{51}$ Nesse sentido, o papel de alguns militantes, como Edgar Leuenroth, deve ser destacado. Membro do Comitê de Defesa Proletária (principal órgão de defesa operária na Greve de 1917 em São Paulo), ele era também um dos grandes articuladores do movimento operário no estado de São Paulo.

Seu papel na Greve Geral de 1917 e na Greve dos Ferroviários é notório. De certa forma, como comentamos anteriormente, a sua ação e a de outros militantes com essas características, mais a afinidade ideológica dos sindicatos, propiciavam a expansão territorial dos movimentos.

Levando-se em consideração que muitas entidades no interior eram filiais dos sindicatos da capital, presume-se que, num momento de crise, a luta de uma categoria tornava-se a luta de uma classe. Independente do resultado, a greve teve como positivo a expansão das atividades sindicais e a criação de várias entidades de trabalhadores, ligas operárias ou mesmo uniões de sindicatos. ${ }^{52}$

Momento histórico e geográfico de grande importância na luta dos trabalhadores, a greve até hoje é lembrada não só por aqueles que de alguma forma estão envolvidos com o assunto (pesquisadores, sindicalistas), mas também por jovens torcedores que no campo de futebol não se esquecem de homenagear aqueles trabalhadores que um dia pararam São Paulo e várias cidades do país.

51 Neste mesmo capítulo, demonstramos alguns casos nos quais os sindicatos, seja nos estatutos ou mesmo na prática da greve, deixavam clara a importância da solidariedade de classe.

52 Para mais informação, ver jornal A Plebe do mês de julho e agosto de 1917, demonstrando os impactos da greve na organização do movimento operário. 
Neste capítulo buscamos apresentar as várias maneiras pelas quais os sindicatos buscavam se organizar na vigência de um Estado liberal. Essas territorialidades existiram até o início da década de 1930, quando então houve uma maior intervenção do Estado nos sindicatos, obrigando-os a "disciplinar" as suas ações territoriais. A ação estatal também traz para dentro do sindicato outra lógica, que não está mais baseada nos princípios de solidariedade entre os trabalhadores, mas no respeito à ordem e aos valores nacionais. 


\section{4 \\ A FORMAÇÃO DE UM ESTADO \\ CORPORATIVO E O MOVIMENTO SINDICAL NO PÓS-1930 NO BRASIL}

As críticas ao modelo liberal partiram de várias ideologias, sejam da esquerda, com o marxismo e o anarquismo, do centro, com a social-democracia pós-Primeira Guerra Mundial, e também por parte da chamada direita, principalmente as críticas fascistas e corporativistas.

Neste momento nossa análise prende-se ao entendimento de como as ideias corporativistas ${ }^{1}$ tiveram uma crescente importância no final do século XIX e início do século XX, na Europa principalmente. Mais adiante, no subcapítulo 4.1, veremos de que forma essa ideologia, ou parte dela, esteve presente no Estado brasileiro após a chamada Revolução de 1930.

Não detalharemos aqui um plano histórico e analítico sobre a emergência dessas ideias. Diante das inúmeras pesquisas que tratam das origens do corporativismo, tivemos como base os trabalhos de Williamson (1990), principalmente aquele que analisa a formação do pensamento corporativo no mundo, bem como as análises que

1 Ao analisarmos as ideias corporativistas e o Estado corporativista, estamos tendo como referência a discussão apresentada por Vieira (1981) acerca das diferenças entre as duas expressões. A primeira ligada às ações das corporações de ofício, anteriores ao capitalismo liberal e a segunda, aparecendo apenas no século XIX, quando da emergência das várias críticas ao modelo liberal. 
Durkheim (2002) realizou no final do século XIX acerca da importância do modelo corporativo na sociedade capitalista. ${ }^{2}$

Entretanto, não teremos sucesso em nossa pesquisa se não discutirmos alguns elementos constituintes do corporativismo, que seriam um dos pilares do pensamento estatal a partir de 1930 no Brasil. Esse Estado em formação na década de 1930, cuja atuação será marcada por uma maior interferência nas relações entre os trabalhadores e os empresários, tinha um componente corporativo de grande expressividade, embora ainda contivesse a presença de alguns elementos liberais na sua constituição interna. ${ }^{3}$

Um fator essencial para se entender as ideias corporativistas é compreender como essa ideologia criticou o modelo individualista presente no corpo da ideologia liberal, no que tange principalmente à negação da ação estatal enquanto fomentadora do bem-estar social. Um ponto chave na crítica corporativista à prática liberal é a afirmação de que esta, ao privilegiar o individualismo desenfreado na sociedade, permitiu, além das grandes diferenças sociais, a miséria e o ódio marcantes entre as classes sociais existentes.

Essas críticas ao liberalismo ocorrem na Europa a partir de meados do século XIX e trazem como principal eixo condutor a busca de uma sociedade supostamente mais harmônica do que aquela existente, na qual os laços sociais fossem mais fortes, tendo como principal exemplo as antigas corporações medievais. Essas ideias corporativistas se apresentavam com mais força em países nos quais

2 Além dos trabalhos citados de Williamson e Durkheim, poderíamos citar, entre outros, os de Stepan (1980) e Williamson (1985).

3 Sobre a formação desse Estado corporativo no Brasil, Araújo (2002, p.35) afirma que "reconhecer a execução de um projeto como orientador da ação e das decisões políticas das elites que assumiram o poder em 1930 não significa dizer que as ideias e propostas nele contidas corresponderam, exatamente, ao modelo corporativo que foi efetivamente implantado. No embate político dos anos 1930 este projeto foi fortalecendo algumas linhas de ação e abandonando outras, recebendo adesões e sendo depurado. Sua implantação constituiu um processo de marchas e contramarchas". 
instituições democráticas, como o parlamento, teriam incipiente ressonância na sociedade.

Para Williamson (1989), isso ocorria, pois

The rise of corporatist thought in the second half of the nineteenth century was a response to the disappearance of the ancient regime in several continental European countries. The response came most immediately from those who had lost out in the development of industrial capitalism and incipient liberal political institutions. (Williamson, 1989 , p. 25$)^{4}$

Na perspectiva dos corporativistas, o liberalismo, além de trazer graves consequências à economia e, por conseguinte, ao cenário social, trouxe também graves problemas de ordem moral. Isso porque a concorrência econômica, algo comum à maioria dos países em expansão industrial na Europa, permitiria a destruição quase total de alguns dos pilares sociais mais defendidos pelos corporativistas: a moral corporativa. É por isso que Durkheim (2002), um dos principais defensores das ideias corporativistas, propõe a superioridade delas sobre o liberalismo. Segundo ele, a sociedade moderna não pode aceitar sem críticas a naturalização do mercado, pois os problemas daí derivados são mais morais do que econômicos. Em suas palavras:

Assim, não é por razões econômicas que o regime corporativo me parece indispensável, é por razões morais. Só ele permite moralizar a vida econômica. [...] Há uma moral profissional do padre, do soldado, do magistrado etc. Por que não haveria uma para o comércio e a indústria? Por que não haveria deveres do empregado para com o empregador, deste para com aquele, dos empresários uns

4 "O surgimento do pensamento corporativista na segunda metade do século dezenove foi uma resposta ao desaparecimento do Ancien Régime em alguns países da Europa continental. A resposta vinha daqueles países que estavam atrasados no desenvolvimento industrial e com incipientes instituições políticas liberais" (trad. livre). 
para os outros a fim de atenuar a concorrência entre eles e regulá-la, a fim de impedir que ela se transforme, como hoje, numa guerra às vezes não menos cruel do que as guerras propriamente ditas? (Durkheim, 2002, p.41)

Ao se remeterem às questões de significado moral, os corporativistas se voltavam também a uma sociedade regulada pelas ordens medievais, que o liberalismo aos poucos eliminou. Ao basear-se nas relações de ordem medieval, o pensamento corporativista entendia o liberalismo como a ascensão de uma sociedade individualista, amoral, antissocial e falsa na defesa do igualitarismo, pois grande parte das pessoas vivenciava situações de extrema penúria.

Para os corporativistas, a igualdade política e econômica apregoada pelos liberais era manifestamente desigual, baseada em princípios que não levavam em consideração a origem do indivíduo. Como relata Williamson (1989),

Liberalism also granted political and economic equality to individuals who in corporatist minds were manifestly unequal. Echoing the medieval order, they argued that society had to be hierarchically ordered, a person's rights and duties reflecting his or her designated status. $^{5}$

A crítica ferrenha aos pressupostos liberais detinha-se também na defesa intransigente do papel do Estado enquanto organizador privilegiado da sociedade. Mais ainda, numa sociedade dividida pela competição desmesurada, as classes sociais só teriam um papel relevante enquanto estruturadoras da ordem social se a presença es-

5 "Liberalismo garantia igualdade política e econômica para os indivíduos, o que para os corporativistas era manifestamente desigual. Remontando à ordem medieval, eles argumentavam que a sociedade tinha de ser hierarquicamente ordenada, na qual os direitos e os deveres de uma pessoa designavam sua condição social" (trad. livre). 
tatal fomentasse o espírito nacional e ambos trocassem as diferenças econômicas pela união com o Estado.

Para os corporativistas, a mudança de um regime liberal para outro de cunho social passaria pela frequente intervenção do Estado, como forma de dirimir as várias mazelas que uma economia com pequena presença estatal fomentava. Nesse sentido, seja através dos valores religiosos, para aqueles que defendiam um sistema corporativista de formação cristã, ou por meio da nação, para os laicos, a sociedade existente de cunho liberal deveria substituir a defesa da livre-iniciativa por valores que demonstrassem a união com Deus ou com a pátria. Para Williamson (1989),

While the majority of corporatists saw their corporatists society working to serve the greater glory of God, there were also a number of secular writers who, although clearly influenced by catholics ideas, ultimately saw nationalism - serving the greater glory of the nationas the bases of appeal that would bind society together. (Williamson, 1989 , p. 26$)^{6}$

Muito embora fossem críticas ao liberalismo, as visões corporativistas de ordem econômica e moral afastavam-nas dos socialistas, os quais, por sua vez, também lhes eram contrários. Estes se fundamentavam na defesa da propriedade coletiva dos meios de produção e da terra (enquanto os corporativistas defendiam a propriedade privada), bem como reconheciam a existência de uma sociedade de classes em luta permanente.

Ao entenderem o Estado como agente primordial de defesa da sociedade, os corporativistas abominavam a luta de classes e viam os sindicatos como veículos para a formação dessa sociedade nacional,

6 "Enquanto a maioria dos corporativistas via sua sociedade corporativista trabalhando para servir à maior glória de Deus, havia também um número de escritores seculares que, embora claramente influenciados pelas ideias católicas, viam o nacionalismo - enquanto servindo à maior glória da nação - como o apelo que ligaria a sociedade em uma única base" (trad. livre). 
e não como organizações em defesa de mudanças sociais. Durkheim (2002), por exemplo, via a união corporativa como um mecanismo de conformação social que negava a validade da solidariedade de classe.

Uma outra questão mais importante é saber quais seriam, na organização corporativista, o lugar e a participação respectiva dos empregados e dos empregadores. Parece-me evidente que uns e outros deveriam ser representados na assembleia encarregada de presidir a vida geral da corporação. Essa só poderia cumprir sua função sob a condição de conter em seu interior os dois elementos. (Durkheim, 2002, p.55)

E apontava qual seria o papel do Estado nessa organização corporativa, como forma de não permitir a supremacia de um grupo sobre o outro

Enfim, é certo que essa organização deveria estar ligada ao órgão central, isto é, ao Estado. [...] Esta não pode ser obra de nenhum grupo particular. (Durkheim, 2002, p.55)

Analisando a compreensão que os corporativistas tinham na relação entre as classes sociais e seus órgãos de defesa, Williamson (1989) demonstra que eles procuravam contrapor a união corporativa à luta de classes, de modo que trabalhadores e patrões se voltassem a um interesse comum.

The corporatists, by advocating the establishment of integrated associations, covering all sections of a function or industry, were anxious to overcome what perceived as the often pernicious activities class associations. [...] This meant that associations representing employes and employers were to exist under the corporatist system. The continued existence of class association was a reflection of the view that different categories within the function would continue to have 
different interests, although these were to be subsumed under the wider common interest of the function. (Williamson, 1989, p.30) ${ }^{7}$

Ou seja, na ideologia corporativista, remontando às guildas medievais, a ideia de classe social, ou a classe social como um interesse comum, era praticamente inexistente. Um dos autores que buscam nas guildas medievais as origens do corporativismo moderno é Durkheim. Vieira (1981) diz sobre isso:

O corporativismo renovado de Durkheim procura sua gênese nas antigas corporações, isto é, nas associações de mercadores e artesãos, localizadas em determinada cidade e destinadas a regular o exercício da profissão, o tempo de trabalho, a qualidade da produção e o combate à fraude. (Vieira, 1981, p.19)

Por essa concepção, os indivíduos mesmo que realizassem funções que estivessem relacionadas a um tipo de indústria (por exemplo, a indústria metalúrgica), não estariam necessariamente ligados a uma classe social específica (nesse caso, a classe operária), mas, principalmente, pertenceriam à sua corporação de ofício.

Ao negarem a necessidade da defesa enquanto classe social e apoiarem a existência dos sindicatos enquanto organizadores dos trabalhadores de cada ofício, os corporativistas entendiam os sindicatos como órgãos de construção de uma sociedade mais justa, reunidos por um "espírito nacional".

Analisando essas prerrogativas corporativistas, Williamson (1989) demonstra que o objetivo dessas ideias era que, com o tempo, as lutas

7 "Os corporativistas, ao advogarem o estabelecimento de associações integradas, cobrindo todas as seções de uma função ou indústria, estavam ansiosos em superar o que eles viam enquanto as perniciosas atividades de associações de classe. Isso significava que as associações de empregadores e de empregados daquela função existiriam sob o sistema corporativista. A existência das associações de classe era um reflexo da visão que as funções internas de uma categoria continuariam a ter diferentes interesses, embora esses fossem subsumidos pelo mais largo interesse comum da função maior" (trad. livre). 
de classes se extinguissem e todos unidos (trabalhadores e patrões) pensassem unicamente naquilo que fosse o melhor para a nação.

Diz:

On the grounds that the corporation was an instrument for justice and applied the national interest, any challenge to its decision would by definition be unjust and contrary to the national interest. Based upon such a premise, corporatists therefore argued that strikes and lockouts and others forms of industrial action could and should be rendered illegal, or their use severely circumscribed. ${ }^{8}$ (Williamson, 1989, p.32)

Desta forma, os sindicatos teriam outra função. Em vez de organizarem os trabalhadores na luta por melhores condições de trabalho, eles, como comenta Vieira (1981), "limitam-se a desempenhar o papel de órgãos parciais dentro de um órgão complexo, a corporação, por sua vez, simples instrumento diante dos fins do Estado" (Vieira 1981, p.38).

Em que pese defenderem a participação da sociedade organizada na construção do Estado corporativista, por meio de seus representantes, os corporativistas não necessariamente apoiavam um sistema democrático. Para Williamson (1989), o Estado corporativista teria como uns dos traços principais a inexistência de mecanismos democráticos, porque ao Estado eram direcionadas todas as prerrogativas de comando social, sendo que o parlamento poderia ser perfeitamente substituído por um conselho de sindicatos patronais e de trabalhadores.

Essa defesa é feita por Oliveira Vianna (1943) ao ponderar que os sindicatos, ao representarem trabalhadores e patrões, teriam

8 "Sob a ideia de que a corporação fosse um instrumento de justiça e voltada ao interesse nacional, qualquer desafio para sua decisão seria injusto e contrário ao interesse nacional. Baseados em tal premissa, os corporativistas argumentavam que as greves e os lockouts e outras formas de ação industrial poderiam e deveriam ser consideradas ilegais, ou seus usos, severamente circunscritos." (trad. livre). 
a função de substituir uma democracia inócua representada pelo parlamento, por uma sociedade corporativista e, por isso, mais democrática. Diz o intelectual fluminense:

é através dele [o sindicato] - e somente através dele - que as nossas classes econômicas, as empregadoras e as empregadas, irão efetivamente - e não teoricamente, como até agora - participar do Estado, penetrar os seus conselhos e corporações e neles realizar a afirmação democrática da sua vontade e dos seus interesses. E isto em grau que o puro e exclusivo processo do sufrágio universal, dos partidos e das assembleias parlamentares de modo algum poderia permitir - como nunca permitiu. (Vianna, O., 1943, p.XI)

No Brasil, a instalação de um Estado corporativista, como analisaremos mais adiante, deu-se numa fórmula diferenciada: o parlamento continuou existindo, sendo que, ao lado dos deputados eleitos, também assumiam as cadeiras representantes delegados pelos sindicatos de trabalhadores e patrões. ${ }^{9} \mathrm{Na}$ Constituinte de 1933, a primeira após a chegada de Getúlio Vargas ao poder, foram eleitos 264 deputados, sendo 40 representantes classistas, escolhidos indiretamente por sindicatos patronais e de trabalhadores (Coelho, 1986, p.3).

Desta forma, o corporativismo se consolida unicamente em sociedades autoritárias, nas quais a vida social teria quase que controle total do Estado. Williamson (1989) aponta alguns grandes eixos estruturadores desse Estado. Dentre eles, a pouca participação popular, uma pequena industrialização, com alguns setores mais estruturados do que outros, e a necessidade do apoio estatal para as indústrias locais terem condições de enfrentar a concorrência externa.

9 Na Constituição de 1934, em seu art. 23, vemos taxativamente que "a Câmara dos Deputados compõe-se de representantes do povo, eleitos mediante sistema proporcional e sufrágio universal, igual e direto; e de representantes eleitos pelas organizações profissionais na forma que a lei indicar”. Mais detalhes ver: <http://www.planalto.gov.br/ccivil_3/constituicao/constituicao34.htm>. 
A partir da proposta de Williamson (1989), percebemos que a construção de um Estado corporativista ocorre em uma situação histórico-espacial bem particular: sociedades com restrita participação popular nas decisões políticas e econômicas; economia largamente dependente da agricultura, com uma produção industrial ainda incipiente; a grande indústria, com ínfima participação no cenário internacional, dependente do Estado para a própria expansão da sua produção.

Essas sociedades se desenvolveriam em regiões nas quais o capitalismo industrial ainda não teria se consolidado, onde as tradições agrárias continuavam a ter relativa força e, portanto, os pressupostos liberais teriam pouca ressonância. Como afirma Williamson,

Corporatism, therefore, appears to have been established in response to the growing tensions of transition from a relatively backward agrarian economy to an essentially restructuring, a shift in the balance between agriculture and industry and the emergence of organized labour. ${ }^{10}$ (Williamson, 1989, p.42)

Baseado nessas considerações, Williamson (1989) estudou particularmente dois países onde a estrutura estatal corporativista teve grande desenvolvimento: o Estado português governado por Salazar, da década de 1920 até o final da década de 1960, e a Itália no período governado por Mussolini (1922-1943). Dentre os autores principais que, segundo Williamson (1989), defendiam a existência de um Estado corporativista, em substituição ao Estado liberal, podemos citar: François Perroux, G. Pirou e Mihail Manoilesco. Trata-se de economistas ou sociólogos de grande influência nos países de origem (Pirou e Perroux, de origem francesa, e Manoilesco,

10 "Corporativsmo, portanto, parece ter-se estabelecido em resposta às crescentes tensões da transição de uma economia agrária atrasada para uma economia capitalista industrial, essencialmente moderna, economia capitalista com grande necessidade de reestruturação industrial, ou seja, em mudança no balanço entre a agricultura e a indústria e a emergência do trabalho organizado" (trad. livre). 
de origem romena), que também tiveram grande importância na formação de um pensamento autoritário brasileiro. ${ }^{11}$

Mihail Manoilesco, um dos principais intelectuais do corporativismo, ao criticar a luta de classes presente nas sociedades liberais, apontava qual seria a função do corporativismo: "A função essencial da corporação é criar um novo ambiente moral, favorável à ideia de colaboração entre empregadores e trabalhadores" (Manoilesco apud Williamson, 1989, p.31, trad. livre). Para o economista romeno, o Estado e os órgãos representantes de trabalhadores e patrões deveriam se unir para que prevalecesse entre os indivíduos a solidariedade econômica, o que ele considerava, segundo Vieira (1981), a expressão suprema da solidariedade.

A defesa da solidariedade corporativa junto ao Estado nacional nega algo ainda mais complexo: a solidariedade classista. Já não é mais a solidariedade da classe operária no seu conjunto, mas a solidariedade de um ofício específico em harmonia com a corporação patronal, e coordenados pelo Estado na busca, supostamente, de um bem-estar de todos. Como demonstra Pirou, outro ideólogo do corporativismo moderno,

A essência do corporativismo é a ideia da união de todos os que exercem a mesma profissão, em um corpo de natureza pública, colocando-se na posição intermediária entre os indivíduos e o Estado. (Pirou apud Vieira, 1981, p.50)

Tanto Maloiesco como Pirou, importantes teóricos do corporativismo, ao defenderem a solidariedade corporativa em consonância com o Estado nacional, de certa forma, questionavam a validade

11 Sobre essas influências nas ideias de Oliveira Vianna, por exemplo, Vieira (1981) comenta que "não temos dúvida de que Oliveira Vianna percorreu autores destacados da doutrina do Estado corporativo, pertencentes a nacionalidades várias e a experiências diversas. A seleção bibliográfica sobre o tema certamente limitou o número de autores citados, que são quase sempre mencionados quando Oliveira Vianna trata do Estado corporativo. As principais fontes utilizadas são obras de Manoilesco, Perroux e Panunzio, sendo ainda citado Pirou” (Vieira, 1981, p.31). 
da proposta socialista, seja a marxista ou a anarquista, de que o indivíduo estaria inserido numa classe social, seja o proletariado ou a burguesia, e, em contrapartida, exaltavam as qualidades do pertencimento a uma corporação específica. ${ }^{12}$

Essa proposição corporativista, em defesa do ofício e não da classe, está em oposição ao pensamento socialista marxista de grande influência nos meios operários, cuja máxima era "Proletários de todo o mundo, uni-vos".

Mais ainda, ao valorizarem a existência das corporações, como instâncias máximas de defesa econômica, procuravam dificultar a compreensão de que o sindicato de uma categoria é também um instrumento da classe operária para a luta de sua emancipação. Isso porque as ideias desses intelectuais defensores do Estado corporativo teriam como objetivo negar a necessidade de uma luta econômica entre as classes sociais.

Esses intelectuais vislumbrariam a divisão da própria classe social, que não se veria mais como um corpo único, mas distribuída em vários ramos econômicos, com interesses sociais específicos, resultando em fragmentação e dispersão das lutas. Num certo sentido, nesse Estado, se alguma união era colocada para o trabalho, ela não estava vinculada à ideia de classe social, mas de corporação, como também na sua relação com o patronato e o Estado.

É como se um dado ramo da indústria, por exemplo, o ramo têxtil, tivesse trabalhadores e patrões unidos para o mesmo objetivo: o progresso da nação. E mais: o sindicato têxtil de trabalhadores não tivesse proximidade com os outros sindicatos de trabalhadores, já que a união seria corporativa e não de classe social.

Nesse projeto, a fragmentação da classe operária acabava sendo a norma e, com isso, enfraquecia-se qualquer luta sindical mais orgânica. Se no Estado liberal, como vimos no caso brasileiro, os

12 "De acordo com a doutrina corporativista, os sindicatos limitam-se a desempenhar o papel de órgãos parciais dentro de um órgão complexo, a corporação, por sua vez, simples instrumento diante dos fins do Estado" (Vieira, 1981, p.38). 
sindicatos se apresentavam conforme as necessidades específicas da categoria, mas também observando a luta mais geral (quando essa união era necessária, urgente), na formação do Estado corporativista, a classe social, quando proclamada a sua união, seria apenas em nome da nação.

A única e viável unidade é a unidade nacional. Não é sem motivo que na legislação corporativista do Brasil, por exemplo, o decreto-lei n.19.770, proibia-se terminantemente a relação internacional entre os sindicatos. Ao definirem o plano categorial como o máximo dentro da organização estatal corporativista, o Estado corporativista promoveu (ou procurou promover) lentamente o sentimento de estranhamento entre as categorias profissionais, pois as categorias passam a ser encaradas como um universo e não mais parte de uma classe social.

Se no Estado liberal a presença das chamadas greves de solidariedade demonstravam o vínculo mais geral entre as categorias, no Estado corporativo essa prática foi quase inexistente. Nesse sentido, quando da formação de um Estado corporativista no Brasil, vai haver uma inversão de solidariedade, já que anteriormente prevalecia uma solidariedade de classe, demonstrada nas greves de solidariedade, como as de 1907 e 1917, e com o corporativismo prevaleceu uma solidariedade de categoria e, assim, a classe social deixa de ser uma unidade e transforma-se em centenas de sindicatos atomizados, com suas preocupações particulares.

Operou-se na passagem de um Estado liberal para outro corporativo, no Brasil, por exemplo, uma inversão das fases de amadurecimento da classe. A própria consciência de pertencimento a uma classe social específica ficaria prejudicada, já que se fortalece ideologicamente a sua separação em várias categorias independentes (algo que já ocorreria economicamente pela própria evolução do capitalismo).

Conhecedores de como essas ideias foram ao longo dos séculos XIX e XX sendo gestadas, importa agora para a nossa discussão compreender de que forma elas se apresentaram no Brasil, preocupando-se em analisar como os pressupostos corporativistas tiveram no país uma aplicação, levando em consideração as necessidades das nossas elites. 


\section{1 - A ação estatal e o controle dos sindicatos no Brasil}

Nessa parte analisamos como se gestou ainda nas primeiras décadas do século XX um pensamento conservador e antiliberal no país, tendo como principais porta-vozes intelectuais de peso, como foi o caso de Oliveira Vianna. ${ }^{13} \mathrm{O}$ Capítulo 2, acerca das ideias liberais no Brasil, mostrou-nos o duplo caráter desta ideologia então dominante no cenário político republicano. Uma dessas contradições era a falsa liberdade apregoada pela elite com relação à organização dos sindicatos, principalmente os mais combativos. Entretanto, outras contradições, nem sempre ligadas à questão sindical, apareciam. Como afirma Fausto (2001), a crítica ao liberalismo ocorreu

nos anos de 1920, na vigência de um regime oligárquico-liberal, que ganhou forma com a proclamação da República (1889). O liberalismo foi associado à prática oligárquica, que pressupunha a fraude eleitoral, a escassa participação política da população e o controle do país pelos grandes estados, enfraquecendo o poder da União. (Fausto, 2001, p.14)

Na década de 1920 vai sendo gestado um pensamento autoritário, antiliberal na sua essência, que tinha apego às tradições e apontava o papel predominante que o Estado deveria ter enquanto grande organizador da sociedade. Para ser concretizado, esse projeto

13 Oliveira Vianna foi um dos principais defensores do Estado corporativo no Brasil, tendo também participado do governo de Getúlio Vargas, no período de 1932 a 1940. A importância de Oliveira Vianna para esse trabalho se explica, entre outras coisas, pela grande presença desse intelectual nas reformas movidas pelo Estado contra os sindicatos. Em sua autobiografia, Vianna afirma ter sido "consultor jurídico do Ministério do Trabalho ou como presidente das comissões que elaboraram os anteprojetos, de que resultaram as nossas últimas leis sindicais - o decreto n.24.694, de 1934, e o decreto-lei n.1.402 de 1939 [...]" (Vianna, 1943, p.35). 
utilizou-se também de alguns recursos do pensamento geográfico de então, principalmente europeu, que tinha a influência das propostas ratzelianas, que, entre outras coisas, propugnava a presença do Estado centralizador, como forma de o país ser forte tanto politicamente como economicamente.

Para Ratzel, o Estado teria a função de, no caso de países com grande extensão territorial, rearticular o espaço fragmentado, distribuindo corretamente a circulação e os elementos de defesa, visto que mais importante do que a extensão do território era a sua coesão interna (Costa, W., 1992). Segundo Moraes (1988), a influência das ideias de Ratzel ${ }^{14}$ na elite nacional das décadas de 1920 e 1930, principalmente, ocorria, pois esse geógrafo alemão

é o pioneiro formulador da geografia política e um teórico do "apetite territorial" do Estado. Vê-se que a proximidade de suas teorizações com a realidade presente para a prática das elites brasileiras é bastante significativa. [...] a geografia é posta claramente como um instrumento de um Estado modernizante, impulsionador do desenvolvimento capitalista no país. (Moraes, 1988, p.130)

Muito embora, como Moraes (1987) demonstrou, Ratzel mantivesse apenas uma visão naturalista do homem, sem necessariamente defender um determinismo nessas ações naturais, essas concepções do geógrafo alemão sugeriram para alguns de seus discípulos ${ }^{15} \mathrm{a}$ formação de um corpo doutrinário conhecido como "determinismo geográfico" e máximas como "o homem é um produto do meio" ou "as condições naturais determinam a História" passaram a ser

14 Friedrich Ratzel (1844-1904) foi um geógrafo alemão, um dos expoentes da chamada antropogeografia e elaborador do conceito de espaço vital, no qual a potencialidade de uma sociedade estaria determinada pela presença ou não de recursos, justificando-se a conquista de novos territórios pelo Estado. Para uma melhor compreensão desse autor, ver Moraes (1987), principalmente o capítulo 5 .

15 Entre eles, poderíamos citar a geógrafa norte-americana Ellen Semple e o geógrafo inglês Elsworth Huntington (Moraes, 1987). 
identificadas como próprias desse autor. Essas concepções estavam presentes nas ideias de alguns intelectuais brasileiros, caso de Oliveira Vianna.

Preocupada em modernizar o Estado brasileiro, a elite que se apossa do poder nos anos de 1930 inicia um processo de controle sobre a sociedade, como também sobre o território nacional. Nesse sentido é criado em 1933 o Conselho Nacional de Geografia (CNG) e, em 1934, o Instituto Nacional de Estatística, organizados a partir de 1942 em um só órgão, formando assim o Instituto Brasileiro de Geografia e Estatística (IBGE) (Costa, W., 1988).

Sobre a criação de institutos como o $\mathrm{CNG}$ e, posteriormente, o IBGE, Costa, W. (1988) registra que

ao lado das outras faces do centralismo e do intervencionismo, essas iniciativas a partir do IBGE eram fundamentais para a consecução de objetivos de alcance notoriamente nacionais, ou seja, forjar uma unidade nacional a partir do centro e não das partes do território nacional. (Costa, W., 1988, p.48)

Os sindicatos, graças à pluralidade e mobilidade existentes até então, surgiam como elementos perturbadores dessa nova ordem. Como forma de enquadrá-los em um novo modelo de sociedade, mais centralizado, o Estado inicia um processo de controle sobre essas entidades, que também incidia sobre a sua territorialidade.

Esse processo, que teria seu ponto culminante no Estado Novo, dedicava atenção especial ao território. Penha (1993) destacou esse aspecto do processo:

o território, neste particular, adquiriu uma discussão política bastante significativa. A intenção de Vargas de tornar o Estado de dimensões tão vastas quanto o país tinha o sentido de redimensionar espacialmente o alcance das políticas governamentais nas quais o controle da população (mercado/nação) e o território (país) eram condicionantes fundamentais não só para a consecução destas 
políticas, como também para a própria consolidação do Estado Nacional. (Penha, 1993, p.65)

A preocupação do Estado em modernizar suas instituições e o apego dessas elites aos novos estudos geopolíticos existentes na Europa e nos Estados Unidos promoveram uma radical mudança na concepção estatal dominante nos tempos do liberalismo. E a Geografia, enquanto ciência, tornar-se-ia um grande suporte para as políticas intervencionistas. Sobre isso comenta Costa, W. (1992)

o prestígio dessa disciplina no país era notável, especialmente no período do chamado Estado Novo, quando ela extravasa os muros do ensino militar e passa a constituir uma das bases para reflexão política sobre aspectos gerais do desenvolvimento nacional. (Costa, W., 1992, p.191)

Uma das ideias-chave presentes no pensamento desses intelectuais conservadores, inclusive Oliveira Vianna, com grande componente geográfico, era a de que o ambiente natural presente em nosso território propiciava a formação de um povo individualista. Além disso, apoiando-se nas ideias de Brunhes e Vidal de La Blache, Vianna destacou o papel que os fatores geográficos tinham na forma do governo colonial. Partidário do centralismo político do Império, criticava os defensores do federalismo no Brasil Republicano, sendo que parte dessas ideias, principalmente no que se refere à questão da unidade nacional, pode ser atribuída a uma influência do pensamento de Ratzel. ${ }^{16}$

Entendendo o povo brasileiro como não solidário e avesso por isso à organização, Oliveira Vianna defenderia, de forma preconceituosa, que se deveria "arianizar" o país, pela via do branqueamento,

16 Para Santiago (2005, p.226), “em Vianna, fica mais difícil de perceber as conexões ratzelianas, pois ele cita Ratzel a partir de Lucien Febvre; todavia boa parte do desenvolvimento de sua temática no que se refere à questão da unidade nacional indica uma influência ainda que difusa do pensamento ratzeliano". 
para dotá-lo de um povo capaz de dar suporte à tarefa da construção nacional (Fausto, 2001). Como ele considerava o povo brasileiro inculto, imerso num grande obscurantismo e, por isso, incapaz de se guiar sem a presença de um Estado mais forte, entendia que o liberalismo não poderia ser aplicado às condições de existência do Brasil.

Um povo marcado pelo insolidarismo ${ }^{17}$ (como afirma Oliveira Vianna) só prosperaria se o Estado interviesse num processo de aglutinação dos indivíduos, pois a própria condição de habitar um país de grande extensão territorial marcaria esse traço dominante de nosso povo. De um lado, apoiando-se em geógrafos e geopolíticos estrangeiros, Vianna era um dos maiores críticos ao federalismo vigente no Estado liberal, sugerindo a ineficácia de um regime federativo num país de grandes dimensões como o Brasil, marcado pelo poder das elites regionais. ${ }^{18}$ Por outro lado, apoiando-se em teóricos corporativistas, demonstrava a partir dessas ideias que o liberalismo também não poderia prevalecer nas relações entre o capital e o trabalho.

As influências sobre Oliveira Vianna eram mais amplas. Além das ideias geopolíticas e corporativistas, nesse pensador, como entre outros intelectuais conservadores desse período, Fausto (2001) aponta também a influência do darwinismo social, das teorias racistas de Gobineau, do positivismo de Comte e da teoria social de

17 Sobre a questão do insolidarismo do povo brasileiro diz Oliveira Vianna: "O fenômeno da distância geográfica, que aqui tão profundamente separa, dissocia e isola os indivíduos ou os subgrupos sociais, lá [na Itália] praticamente está eliminado" (Vianna, O., 1943, p.175).

18 Sobre essa relação entre os geopolíticos estrangeiros e os nacionais, Costa, W. (1992, p.188) afirma que se observa na leitura de algumas obras de geopolíticos brasileiros "a absorção imediata das ideias geopolíticas que se desenvolviam na Europa, a ênfase naquelas teorias que privilegiam a necessidade de unidade territorial e, ao nível do ambiente ideológico interno, a transposição para as fórmulas geopolíticas das principais ideias do conservadorismo nacional (antirrepublicanas, antidemocráticas e antifederativas), como as expressas por Alberto Torres e Oliveira Vianna”. 
Taine, Lebon e Pareto, estas últimas preconizando a irracionalidade das massas e o papel que deveria ter as elites nesse contexto.

No que tange à presença do pensamento corporativo, as ideias de François Perroux, G. Pirou e Mihail Manoilescu exerceram grande influência nesses intelectuais que discutiam as mazelas que o Brasil apresentava como fruto da composição, de um lado, do aspecto natural do país (grande extensão territorial e clima quente) e, de outro, pela presença de uma ideologia liberal que acentuava esse individualismo natural do povo brasileiro.

Avessos aos ditames contraditórios da ideologia liberal no país, esses intelectuais conservadores não procuravam os acertos necessários para que tal modelo ideológico incorporasse a maior parte dos brasileiros no cenário político e econômico. Pelo contrário, o que defendiam era o enfraquecimento total das ideias liberais e a transformação de uma sociedade liberal-oligárquica em uma sociedade corporativista.

Para eles, os sindicatos imbuídos de um sentimento nacional teriam o papel de transformar a vivência individualizada do povo brasileiro em núcleos de organização coletiva, a serviço da nação. Os sindicatos, de polos aglutinadores dos trabalhadores, veículos de defesa econômica, embriões da nova sociedade socialista (para sindicalistas-revolucionários), se transformariam, na visão desses intelectuais brasileiros, em instrumentos do Estado para a emergência de um espírito nacional. ${ }^{19}$

Em uma sociedade marcada pelo liberalismo, os sindicatos até poderiam ser tratados como entidades privadas, dirigidas e embasadas politicamente apenas pelas necessidades mais prementes dos seus associados. Mas, no Estado corporativo, os sindicatos deveriam servir para uma função "maior" do que a luta econômica: trabalhar

19 Analisando um dos principais livros de Oliveira Vianna, Vieira (1981, p.29) diz: "O mesmo se pode dizer de Evolução do povo brasileiro, que apenas expressa a opinião de que os sindicatos e as corporações são fatores de aceleração do domínio do nacional sobre o local". 
em torno de um espírito nacional, buscando, como uma agulha imantada, ligar a população a um poder centralizado.

Permitir que as entidades sindicais funcionassem com maior autonomia, o que era característico dos Estados liberais, seria um grande contrassenso, visto estarmos em um país no qual, pelas condições geográficas aqui dominantes (extensão territorial, clima tropical), o povo tornou-se indolente e individualista. Para Oliveira Vianna (1951),

O velho liberalismo de 91 [Constituição de 1891] havia deixado o trabalhador brasileiro entregue a si mesmo, à fraqueza do seu individualismo, ao desamparo da sua condição de isolado e acabou atirando-o dentro da ilusão de uma liberdade meramente teórica, na indigência e, por fim, na miséria orgânica. (Vianna, O., 1951, p.138)

O Estado e os sindicatos, unidos por um único interesse: organizar os trabalhadores, ensiná-los o espírito coletivo e promover o sentimento nacional. E, dentro do espírito corporativista, os sindicatos sofreriam a intervenção necessária do Estado e transformar-se-iam de entidades privadas em sociedades com apelo público. ${ }^{20}$

O papel dos sindicatos na formação do Estado corporativo brasileiro teve uma função-chave: instruir o povo sobre os valores nacionais mais determinantes para a construção de uma identidade patriota. Os sindicatos no país deveriam se afastar das lutas que seus similares anteriormente empreenderam em prol de uma sociedade mais igualitária e se voltarem a um aspecto mais importante: a formação de um espírito coletivo nacionalista.

Para esse fato se consumar, segundo a visão coporativista, deveria-se condenar a luta de classes e o combate sistemático ao capital. Isso porque, aqui em nosso país, a questão social nunca ocorreu e, se

20 Como afirma Oliveira Vianna (1951, p.85), "essas instituições sindicais são verdadeiras escolas de educação moral e de educação cívica, quero dizer, de educação do homem brasileiro no sentido da solidariedade social, na compreensão do interesse coletivo, na consciência do bem comum das suas respectivas profissões". 
existiu em algum momento, foi importada por indivíduos nocivos e contrários à presença desse sindicalismo mais nacionalista. ${ }^{21}$

Para Oliveira Vianna o sindicato deveria funcionar como elemento estruturador do povo brasileiro, organismo vinculado diretamente ao Estado e promotor do espírito coletivo inexistente ainda entre nós. Além disso, seria o incentivador do nacionalismo, negando-se a ser um instrumento de disputa entre as classes, já que "não é tanto uma técnica de organização profissional, mas, antes de tudo, uma técnica de organização social do povo" (Vianna, O., 1951, p.82).

A mudança de postura de um Estado corporativo em formação em relação a um Estado liberal, no que diz respeito ao funcionamento dos sindicatos, é clara: se no liberal havia alguma possibilidade de ação mais autônoma, no corporativo o sindicato não deveria funcionar autonomamente pelos seus interesses, pela busca constante da transformação social da classe como um todo. No Estado corporativo, o sindicato é uma esfera social que deve ser controlada, não só por meios coercitivos, mas principalmente por meios ideológicos.

A intervenção do Estado nos sindicatos, para Oliveira Vianna, um dos principais dirigentes desse processo no Brasil, explicava-se da seguinte forma:

para que uma política econômica nacional possa ser orientada pelo Estado - é óbvio -, faz-se mister que o governo tenha poder para fazer chegar essa orientação às categorias de produção interessada - o que seria possível com o sindicato integrado no Estado, controlado por ele, partilhando da autoridade deste para os efeitos da duração e disciplina interna da própria categoria. (Vianna, O., 1943, p.13)

21 "O que tem retardado o trabalho de aproximação das duas classes - quando tudo no nosso povo nos leva a isto, quando nada justifica senão a sugestão estrangeira e a ação de elementos estranhos, esta hostilidade contra o burguês e contra o patrão? Essa hostilidade é uma enxertia, uma intoxicação; não é nossa" (Vianna, O., 1951, p.115). 
Os sindicatos passam a ter que seguir um único modelo de organização, voltado claramente aos interesses do Estado. A intervenção estatal promoveu homogeneização nas entidades que aceitavam essa ingerência oficial. A organização interna passaria a ser determinada pela lógica estatal corporativista, buscando a inserção de funções que poderiam soar estranhas, se não ofensivas, aos líderes sindicais das primeiras décadas do século XX. ${ }^{22}$

Ao analisar os decretos que vigoraram na formação do Estado corporativo no Brasil, em especial o decreto-lei n.19.770, de março de 1931, vimos que tais decretos apontavam o caminho que os sindicatos deveriam seguir, caso quisessem ser reconhecidos pelo Estado.

Aos sindicatos que priorizavam a resistência ao capital como estratégia de conquista, o Estado os combateria em diversas frentes, por meio da repressão com invasão policial nas suas entidades ou da presença de investigadores do Dops entre os trabalhadores ${ }^{23}$ como forma de controlar as movimentações das entidades de classe, mas também promovendo a divisão da categoria ao incentivar a criação de novas agremiações sindicais.

As entidades que surgiam dentro do processo de legalização, automaticamente se inseriam na proposta oficial e então aceitavam as novas determinações do Ministério do Trabalho. No decreto-lei n.19.770, o artigo $1^{\circ}$, que regia a participação de estrangeiros nos sindicatos, e o $12^{\circ}$, que comentava sobre a relação dos sindicatos com entidades internacionais, proibiam que as entidades de trabalhadores se aliassem aos seus congêneres internacionais, deter-

22 Por exemplo, a presença de uma enorme burocracia, com suas diversas diretorias, nas quais o acesso direto ao presidente seria improvável.

23 Analisando alguns prontuários do Dops, por exemplo, o da Federação Operária de São Paulo, via-se regularmente, no envio de relatórios de seus investigadores para o delegado geral, a ata inteira do dia de trabalho sindical, quais eram os participantes, suas profissões, os debates ocorridos, a linha proposta pela entidade estadual, demonstrando que, possivelmente, o policial não era um indivíduo secundário na organização de trabalhadores. Para uma nova consulta, ver prontuário n.716, da Federação Operária de São Paulo, 4 volumes, e n.122, de Edgar Leuenroth, 2 volumes. 
minando, como aponta Costa, S. (1986), "a intenção de limitar a liderança sindical, principalmente quando se verifica que muitos trabalhadores estrangeiros que atuavam no meio sindical possuíam ideias por vezes radicais" (Costa, S., 1986, p.14).

Outra preocupação dos dois artigos era que, ao proibirem o contato dos sindicatos brasileiros com entidades de classes internacionais, comuns no início do século XX, tinham também, como comenta Costa, S. (1986),

a intenção de reduzir a capacidade reivindicativa dos trabalhadores em geral, visto que nas primeiras décadas deste século a influência dos movimentos sociais europeus, principalmente na parte doutrinária, era uma constante em nosso país. (Costa, S., 1986, p.14)

Ao proibir as manifestações internacionais nos sindicatos, esse decreto-lei demonstra a intenção do Estado em tentar diminuir a ação mais revolucionária. Como vimos no capítulo anterior, eram comuns essas relações entre as entidades de trabalhadores, fossem aquelas que se guiavam pelo sindicalismo-revolucionário, então ligadas organicamente a uma central sindical estrangeira (caso da CFT francesa), ou fossem as comunistas ligadas à ISV (Internacional Sindical Vermelha), na então União Soviética.

Ao incentivar uma ideologia nacionalista como guia ideológico dos sindicatos, o Estado corporativista tinha que arrefecer, pelo menos, a presença de estrangeiros nessas entidades, o que, por conseguinte, diminuía a interlocução destes organismos com o exterior. E, ao reduzir a presença desses segmentos nos sindicatos, o projeto de controle corporativo conseguia avançar ainda mais, buscando o controle sobre as atividades que propiciariam maior conflito. ${ }^{24}$

24 Vianna, O. (1943), ao comentar alguns aspectos do decreto-lei n.19.770, afirmava que "o pensamento dominante daquela lei era tornar os sindicatos órgãos exclusivos dos interesses profissionais. Nosso sindicalismo nunca afetou qualquer colorido revolucionário: não conhecemos o sindicato de combate" (Vianna, O., 1943, p.37). 
No caso do $5^{\circ}$ artigo do decreto, os sindicatos precisavam de, além do necessário reconhecimento da entidade pelo Ministério do Trabalho, Indústria e Comércio, "fundar e administrar caixa beneficente, agências de colocação, cooperativas, serviços hospitalares, escolas e outras instituições de assistência [...]" (Costa, S., 1986, p.13).

Ou seja, os sindicatos seriam transformados em entidades assistenciais, sendo que a partir desse reconhecimento, segundo Costa, S. (1986),

Amenizando seu caráter de luta e canalizando também, para dentro do aparato estatal, os conflitos sociais. Isto porque os sindicatos passavam, por determinação legal, a serem órgãos consultivos e técnicos do governo federal, caracterizados como entidades de colaboração com o poder público. (Costa, S., 1986, p.13-14)

Esse decreto-lei expressava outra importante intenção do Estado corporativista ao intervir nos sindicatos: transformá-los em correntes de transmissão dos interesses governamentais e diminuir a combatividade. Os sindicatos, tornados agora entidades de apreciação colaborativa e assistencial, perderiam, aos poucos, o seu caráter combativo e de aproximação constante com outras entidades similares. Outro artigo do decreto-lei, o $15^{\circ}$ artigo, determinava que

O Ministério do Trabalho junto aos sindicatos delegados [...] com a faculdade de assistir as assembleias gerais e a obrigação de, trimestralmente, examinar a situação financeira dessas organizações, comunicando ao Ministério, para os devidos fins, quaisquer irregularidades ou infrações referentes a normas estabelecidas naquele decreto. (Costa, S., 1986, p.15)

Este artigo impunha também que, numa eventual greve (levando-se em consideração que o controle estatal ainda não conseguisse evitá-las), a necessidade de se ter a formação de um fundo de sustentação do movimento grevista estaria dependente da con- 
cordância ou não do Estado. Por essa análise fica clara a face desse processo de intervenção estatal. Diminuir o poder de articulação dos sindicatos, transformando-os em entidades de defesa do trabalhador sem muita preocupação em resistir às manobras políticas e/ou econômicas do capital e do Estado.

\section{2 - A intervenção nos sindicatos na década de 1930 e a formação do Estado corporativo no Brasil}

O processo de instituição de um Estado corporativo no país tem como ponto inicial a chegada de Getúlio Vargas ao poder, na chamada Revolução de 1930. A presença de novos grupos oligárquicos nesse movimento tem várias interpretações acerca do papel das elites nesse processo. Antunes (1982) destaca que o movimento de 1930 não se enquadraria como um ato revolucionário, ou seja,

A transição que caracteriza esse período não foi, na verdade, revolucionária, pois 1930 marcou um momento de rearranjo do bloco do poder, rearranjo este feito pelo alto, excluindo qualquer participação efetiva das classes subalternas, e tendo um componente conciliador bastante nítido. (Antunes, 1982, p.67)

Portanto, para Antunes (1982), houve pouca participação das camadas mais populares no processo de mudança política ocorrido em 1930. Em contrapartida, para um dos fundadores do Partido Comunista, essa mudança de governo que ocorre no início da década de 1930 se inscreve da seguinte forma:

A chamada Revolução de 1930, movimento armado dirigido por Getúlio Vargas, contando com uma forte participação de jovens oficiais e um amplo apoio popular, conquistou o poder, modernizou as instituições políticas e sob a pressão das massas, concedeu aos trabalhadores várias vantagens econômicas e políticas. (Pereira, 1976, p.13) 
Com relação à aliança dessa elite com o capital internacional, a visão predominante no Partido Comunista à época era de que houve uma substituição da elite paulista aliada ao capital britânico pela elite gaúcha aliada ao capital norte-americano. Mendonça (1990) aponta as principais linhas de investigação sobre a chamada Revolução de 1930. Um autor importante nesse debate é Werneck Sodré (1963). Segundo Mendonça (1990), as interpretações de Sodré sobre o evento sinalizam que o movimento de 1930 marcou a ascensão da burguesia industrial ao poder e tinha como objetivo a superação de uma política contraditória, na qual elementos arcaicos (como a agricultura de exportação de base feudal) e modernos (presença de setores urbano-industriais) conviviam.

Nessa perspectiva, Sodré (1963) afirma, a respeito da derrocada das elites mineira e paulista e a ascensão da elite gaúcha ao poder em 1930:

A aliança que se estabelece entre os grupos militares já precursores de uma transformação de que não tinham consciência muito exata e os grupos da classe dominante insatisfeitos com a orientação financeira e econômica do governo, responsável sempre por todos os males, constitui uma força contra a qual o poder oficial não tem recursos. A Revolução de 1930 assinala, na história brasileira, o primeiro exemplo de movimento revolucionário que parte da periferia sobre o centro. (Sodré, 1963, p.322)

Contrapondo-se à visão de que esse movimento foi a revolução burguesa brasileira, o trabalho de Fausto (1972) avalia que os eventos históricos demonstram que a Revolução de 1930 não foi uma luta entre dois grupos antagônicos, mas sim, uma reorganização das elites em aliança com os militares, na procura da formação de um estado de compromisso entre algumas forças políticas existentes.

No que diz respeito ao modelo ideológico seguido pela elite que chega ao poder em 1930, Fausto (1997) demonstra que as fórmulas liberais predominantes até o final da década de 1920 são lentamente abandonadas. 
Do ponto de vista ideológico, os quadros dirigentes tendem a abandonar as fórmulas liberais, considerando-as francamente superadas, não obstante o fato de que o compromisso se instale também nesse nível, como se verifica pelos dispositivos da Constituição de 1934. (Fausto, 1997, p.142)

Colocando-se numa linha de interpretação na qual os "vencidos" possibilitariam um processo revolucionário em 1928, com a liderança do Partido Comunista, De Decca (1983) caracteriza o movimento como um contragolpe orquestrado pela elite industrial, com a intenção de apagar da memória a verdadeira luta de classes.

Para De Decca (1983), o PCB, por meio de sua frente legal, o BOC (Bloco Operário e Camponês), conquistou grande apelo entre a classe operária e, pregando abertamente a luta de classes, defendia uma revolução popular. Ele considera que a fundação do Ciesp (Centro das Indústrias do Estado de São Paulo) ocorreu como um enfrentamento da burguesia industrial paulista a algumas leis sociais existentes na década de 1920.

De Decca (1983) traz de importante para a reflexão historiográfica a análise de que o medo da elite industrial paulista de uma ação mais violenta liderada pelo $\mathrm{PCB}$, ao promover um maior enrijecimento das mobilizações populares, levou a um endurecimento do regime e, por fim, à Revolução de 1930. De certa maneira, questiona a visão predominante na historiografia até aquele momento de que as camadas populares participaram apenas como expectadoras das mudanças que ocorriam.

Contrário a essa análise, Fausto (1997), ao fazer um balanço historiográfico, aponta que a classe operária não seria madura suficiente para forjar uma ruptura da ordem vigente. Diz:

Convém apenas lembrar que se trata, no caso de uma aplicação equivocada da vertente historiográfica que introduziu uma nova abordagem, concentrando-se na história dos dominados ou vencidos. No Brasil da década de 1920 não havia conjuntura revolucionária em que o proletariado tivesse a iniciativa, não chegando a 
classe operária organizada a constituir um ator político relevante. (Fausto, 1997, p.17)

Para nós, mais do que aceitar essa ou aquela interpretação, importa entender o significado dessa transformação no que diz respeito à passagem de uma estrutura liberal para outra corporativa, como também de uma economia agrária para uma economia industrial. O fim de um Estado liberal e oligárquico representou uma maior ação do Estado na economia, promovendo lentamente uma maior ingerência nos assuntos privados.

O que fica claro é que, rejeitando o modelo liberal oligárquico predominante até meados da década de 1920, os novos governantes procuraram impor uma nova dinâmica com relação à atuação do movimento operário. Até então, largamente baseados em decretos e leis que permitiam relativa autonomia, os sindicatos, dentro de um espírito corporativista, passaram a ser encarados como um dos principais alicerces dessa nova sociedade.

As mudanças mais importantes, em relação ao nosso objeto de estudo, ocorreram com a aplicação do decreto-lei n.19.770, de 19 de março de 1931. A partir daí iniciam-se os procedimentos para a oficialização dos sindicatos e várias regulamentações sobre o funcionamento dessas entidades, transferindo para o Estado as prerrogativas acerca da organização dos trabalhadores.

É nesse momento que fica evidente uma mudança na prática estatal com relação à atuação dos sindicatos. $\mathrm{O}$ Estado passa a ser um elemento importante na organização das entidades e definirá as suas linhas de atuação, seja na forma organizativa interna, nas relações com os patrões e o Estado, seja nas relações com as outras entidades, características, até então, definidas pelos próprios filiados.

Baseados largamente nas ideias que apontamos anteriormente, aqueles que ficariam incumbidos de julgar a adequação dos sindicatos (novos) ou a legalização dos já existentes, bem como emitir pareceres favoráveis ou não às solicitações dessas entidades, caso de Oliveira Vianna, chegaram a importantes postos da máquina 
burocrática e implementaram os novos paradigmas para o sindicalismo brasileiro.

Ao proporem a intervenção do Estado nas entidades sindicais, procuraram "organizar" esses agrupamentos conforme as necessidades do governo instituído a partir de 1930. Esse processo de oficialização dos sindicatos, que se inicia em 1931, com o reconhecimento de 39 sindicatos, não tem grande êxito até o ano de 1936, excetuando 1933, quando foram reconhecidas 259 entidades.

Um dos motivos da queda, a partir de 1933, do número de sindicatos que pediam o reconhecimento estatal seria uma mudança na legislação sindical ocorrida em 1934, quando retorna a pluralidade sindical (Antunes, 1982).

Tabela 4 - Número de sindicatos reconhecidos anualmente entre 1931 e 1936 - DF (Antigo Distrito Federal), SP (São Paulo) e Brasil (BR) $(1933=100)$

\begin{tabular}{lllllllllllll}
\hline & 1931 & \multicolumn{1}{c}{1932} & \multicolumn{1}{c}{1933} & \multicolumn{2}{c}{1934} & \multicolumn{3}{c}{1935} & \multicolumn{2}{c}{1936} \\
& $\mathrm{~N}^{\mathrm{o}}$ & $\%$ & $\mathrm{~N}^{\circ}$ & $\%$ & $\mathrm{~N}^{\circ}$ & $\%$ & $\mathrm{~N}^{\circ}$ & $\%$ & $\mathrm{~N}^{\circ}$ & $\%$ & $\mathrm{~N}^{\circ}$ & $\%$ \\
\hline $\mathrm{DF}$ & 21 & 105 & 025 & 125 & 020 & 100 & 008 & 040 & 13 & 65 & 011 & 55 \\
$\mathrm{SP}$ & 02 & 004 & 006 & 11,5 & 052 & 100 & 027 & 052 & 16 & 31 & 013 & 25 \\
$\mathrm{BR}$ & 39 & 015 & 116 & 45 & 259 & 100 & 208 & 080 & 69 & 27 & 106 & 41 \\
\hline
\end{tabular}

Fonte: Vianna, L. (1976).

A tabela 4 revela uma pequena participação de São Paulo e do antigo Distrito Federal no número de sindicatos, demonstrando que os sindicatos de locais afastados das áreas mais industrializadas foram os que aceitaram esse processo. Nas áreas mais afastadas dos principais centros industriais, onde a organização dos trabalhadores era muito incipiente, o assédio estatal tinha maior ressonância, por parte dos sindicatos, pois muitos deles aceitavam a oficialização como forma de amealhar as benesses que as leis trabalhistas propiciavam. ${ }^{25}$

25 Entre elas poderíamos citar o decreto n.23.679, de 18 de janeiro de 1934, que regulava as férias dos empregados da indústria, desde que associados aos sin- 
Para Costa, S. (1986), a pequena presença de sindicatos, principalmente nas áreas mais industrializadas, solicitando o reconhecimento, devia-se a duas principais situações

A primeira refere-se ao modo como o governo utilizou determinadas leis básicas para os trabalhadores, estabelecendo que seu cumprimento só poderia ser reivindicado, caso fossem desrespeitadas pelos empregadores, por intermédio de sindicatos oficiais. A segunda situação foi a criação da representação classista - tanto de empregados quanto de empregadores - junto à Câmara dos Deputados [...] por meio de organismos sindicais oficiais. (Costa, S., 1986, p.23)

Antunes (1982), analisando os sindicatos operários da indústria de transformação, aponta que até a metade da década de 1930 eram poucas as entidades que se submetiam ao processo de intervenção estatal.

No ano de 1934, em São Paulo, por exemplo, somente 43 sindicatos eram oficiais; no Rio de Janeiro, 41. Estas duas sedes mais industrializadas tinham somente $25 \%$ dos sindicatos reconhecidos pelo Ministério do Trabalho; Rio Grande do Sul e Minas Gerais participavam com 25,5\%. À medida que se caminha em direção às áreas com menor índice de industrialização, como Bahia, Santa Catarina, Pernambuco, Pará, Paraná, Sergipe, Espírito Santo, Amazonas, Maranhão e Piauí, torna-se maior o número de sindicatos reconhecidos, cujos índices aproximam-se a 50\% do total. (Antunes, 1982, p.84)

Nas áreas mais industrializadas, algumas daquelas entidades de classe mais combativas que optaram pelo não reconhecimento começaram a sofrer assédio oficial e passaram a rever suas posições, pois uma parte da categoria já aceitava a participação na nova ordem sindical.

dicatos de classe reconhecidos pelo Ministério do Trabalho (Antunes, 1982, p.113). 
Um caso no qual houve a divisão de uma categoria, tendo em vista as mudanças na legislação sindical e trabalhista, foi o dos trabalhadores metalúrgicos de São Paulo. Até o início da década de 1930, os metalúrgicos eram representados pela União dos Metalúrgicos de São Paulo, que exercia forte influência sobre a categoria. Em 1932, buscando aceitar as novas determinações estatais, foi fundado o Sindicato dos Metalúrgicos de São Paulo. Até 1934 as duas entidades diziam representar a categoria; a União, tendo o respaldo da maior parte dos trabalhadores, e o Sindicato, aceito como órgão oficial e "legítimo" representante da categoria.

Afora esse caso, Antunes (1986) cita o exemplo dos trabalhadores da Light. O sindicato representante da categoria, a União dos Trabalhadores da Light, era filiado à FOSP e, por isso, fazia grande oposição às políticas governamentais do período. Uma nota oficial da FOSP publicada no jornal A Plebe deixava clara a postura da entidade e de seus filiados com relação ao decreto-lei 19.770:

\section{A Lei de Sindicalização}

Repetidas vezes a Federação Operária tem declarado não estar de acordo com a fascistização dos sindicatos [...] os agentes do Ministério do Trabalho em vez de cumprirem sua missão se aliaram aos reacionários para impedirem que os trabalhadores estejam dentro das suas organizações de classe e prevalecendo-se de seus cargos fazem a maior propaganda contra as organizações de classe que não aceitam o controle do Ministério, ou seja, que não se submetem aos caprichos e fiscalização dos patrões [...] (A Plebe, 26/11/1932, p.4)

Conforme o assédio governamental aumentava, a possibilidade de manterem-se como único representante da categoria parecia ficar inviável, uma vez que alguns benefícios, como a lei de férias, só seriam efetivados aos trabalhadores filiados aos sindicatos oficias. Em 1934, cedendo à pressão ministerial, uma parte da categoria resolve formar outra entidade, o Sindicato dos Operários em Tra- 
ção, Força e Luz, possivelmente reconhecida pelo Ministério do Trabalho.

o Ministério do Trabalho, de parceria com os industriais, fundaram uma Federação do Trabalho do Estado de São Paulo [...] com o fim de impedir o desenvolvimento das organizações revolucionárias, cremos ser o nosso dever chamar atenção do proletariado consciente para que não poupe esforços em fazer fracassar os intentos dos inimigos da classe produtora. (O Trabalhador da Light apud Antunes, 1982, p.96-97)

A postura governamental tinha uma proposta parecida tanto para as entidades locais quanto para sua organização maior, a Federação Operária: dividi-las territorialmente para assim, aos poucos, aniquilá-las. A partir de 1933, pelos motivos apontados anteriormente, vários sindicatos combativos tiveram que enfrentar uma dura batalha à concorrência oficial. A imprensa operária, como demonstra Bernardo (1982, p.102), “[...] passa a veicular notícias que caracterizam a divisão que se vinha processando desde a publicação do decreto n.19.770".

Com a efetivação dessa prática e seus resultados sendo positivos, as categorias mais combativas aos poucos vão diminuindo sua influência entre os trabalhadores. Com isso, uma parte da memória sindical passa por um lento processo de supressão. Oliveira Vianna não reluta em ressaltar as conquistas dos trabalhadores como outorga, omitindo que antes de 1930 houve lutas operárias e que elas foram de extrema importância.

Em primeiro lugar, antes de entrar na análise das realizações dessa política, desde 1931 até o momento [1951], quero ressaltar essa singularidade do seu método de ação, que é o de ser ela uma iniciativa do Estado, uma outorga, generosa dos dirigentes políticos - e não uma conquista realizada pelas massas trabalhadoras. (Vianna, O., 1951, p.66) 
Não surpreende então que uma boa parte do sindicalismo atual, surgido ou tendo seu representante transformado a partir de 1931, com a Lei de Sindicalização, pouco sabe das primeiras lutas em busca de melhores condições de vida e afirme que a origem de sua entidade está ligada às mudanças ocorridas com a intervenção estatal nos sindicatos.

Um desses exemplos é o Sindicato dos Metalúrgicos de São Paulo, herdeiro das tradições comentadas anteriormente. O site do sindicato, acessado em 2011, na parte relativa ao seu histórico, afirma que a entidade foi fundada em 27 de dezembro de 1932 e registrada no Ministério do Trabalho em 1933, sem mencionar uma linha sequer sobre as lutas anteriores à sua fundação, como se elas não existissem. É importante ressaltar que apesar da efetivação do projeto de intervenção corporativista, inúmeras resistências surgiram, conforme as entidades de trabalhadores mais combativos eram assediadas pela nova legislação.

Diferentemente do que ocorria até o início da década de 1920, quando os sindicatos-revolucionários tinham quase que total predominância entre os sindicatos mais combativos, a partir da década de 1930, as principais forças de esquerda se dividiam em, pelo menos, três facções: os sindicatos de orientação anarquista, os comunistas e os trotskistas.

\subsubsection{Os sindicatos de orientação anarquista}

O processo de intervenção estatal nos sindicatos atingiria fortemente os sindicatos de orientação anarquista. Isso se deveu ao fato de que ideologicamente eram contrários a qualquer presença do Estado nas relações entre o capital e o trabalho, entendendo essa participação como a de um elemento estranho que francamente pendia para o lado patronal.

Os sindicatos de orientação anarquista eram herdeiros diretos das lutas ocorridas até o início da década de 1920, como as greves gerais de 1907, 1917 e 1919, nas quais tiveram um papel prepon- 
derante. Esses movimentos marcaram sobremaneira o sindicalismo brasileiro, demonstrando a capacidade de articulação das várias entidades existentes, muito embora a própria constituição da classe operária ainda fosse incipiente.

Com a fundação do Partido Comunista em 1922, essas entidades começaram a sofrer um grande assédio daqueles que defendiam uma maior centralização das lutas operárias, ocasionando uma diminuição na sua influência. Outro importante motivador dessa decadência foi o constante questionamento do Partido Comunista acerca de seu apoliticismo partidário, o que inviabilizava a participação dos trabalhadores em instâncias oficiais, como o parlamento. Outro fator de enfraquecimento desses sindicatos foi a série de perseguições impetradas pelo governo Arthur Bernardes na década de 1920, culminando com a deportação dos militantes estrangeiros e o envio de dezenas de lideranças brasileiras para a região de Oiapoque, na colônia de Clevelândia, onde a maioria pereceu. ${ }^{26}$

Em que pesem essas dificuldades, até a metade da década de 1930 esses sindicatos teriam uma importante participação no movimento sindical, principalmente no Estado de São Paulo. Atuando de forma independente e contrária a qualquer intervenção do Estado, os sindicatos de orientação anarquista constantemente repudiavam a transformação dos sindicatos em órgãos de fachada, nos quais as principais tarefas vinculavam-se, prioritariamente, a trabalhos de ordem assistencial, negando quase sempre o papel combativo que deveriam ter essas entidades.

Ainda que já não expressassem o vigor existente até o fim da década de 1910, quando algumas de suas ideias estiveram entre as principais lideranças sindicais e na direção de grandes greves, como a de 1917 em São Paulo, esses sindicatos procuravam continuar

26 “Tal acontecimento, uma verdadeira tragédia, só conhecida pelo público após o fim do estado de sítio e de censura à imprensa, no início de 1927, envolveu quase mil pessoas. Desse número, mais da metade não retornou ao lar após o governo de Bernardes, ficando sepultados, vitimados por doenças e pelo abandono." (Samis, 2004, p.171). 
afirmando sua profunda recusa em participar de eleições, conclamando a união da classe operária em órgãos de defesa proletária e não em partidos.

Rejeitando qualquer presença estatal nas suas organizações sindicais, esses sindicalistas, a todo o momento, em seus periódicos, ${ }^{27}$ atacavam a legislação sindical vigente, bem como as entidades constituídas a partir dela.Diziam sobre o Ministério do Trabalho:

O Ministério do Trabalho, permita-me dizê-lo, é uma dessas "blagues" que costumam aparecer em nosso país. Nós o combatemos sistematicamente, pela sua inutilidade. E damos as nossas razões. A Lei de Sindicalização que mereceu o desbarretamento dos pobres de espírito e a censura dos que possuem agudez bastante para descortinar através de seu fraseado um atentado contra as classes operárias, nada mais, em súmula, do que a Carta Del Lavoro que Mussolini impôs ao operariado italiano, disfarçada entre nós com este rótulo falso de Lei de Sindicalização. (A Plebe, 1932, apud Antunes, 1982, p.105)

Essa recusa em aceitar a lei que regia o sindicalismo, mas também a legislação que determinava benefícios aos trabalhadores vinculados aos sindicatos oficiais, como a Lei de Férias, de 1934, trouxe diversos questionamentos acerca desse tipo de luta sindical e ocasionou várias dissensões internas, quando uma parte da categoria, aceitando as prerrogativas estatais, formava entidades com a clara intenção de serem oficializadas, casos dos

Sindicatos dos Operários em Fábricas de Vidro e dos Trabalhadores em Fábricas de Chapéus, que não conseguiram sobreviver muito tempo depois que foram organizados, sob a orientação ministerial, os sindicatos oficiais destas duas categorias, reconhecidos

27 Entre eles, poderíamos citar o jornal A Plebe, existente na primeira metade da década de 1930. 
respectivamente em dezembro de 1932 e em maio de 1933. (Araujo, 1994, p.189)

Minado pelas várias divisões que seus sindicatos sofreram com as mudanças oficias e com a acentuação das disputas políticas entre a esquerda, representada pela ANL (Aliança Nacional Libertadora), e a direita, representada pela AIB (Ação Integralista Brasileira), esse sindicalismo se desestrutura politicamente, ${ }^{28}$ pois se fortalecem no meio operário as ideias comunistas, aparecendo a partir desse momento como única representante das esquerdas no país.

O movimento comunista de novembro de 1935, conhecido como Intentona Comunista, e a implantação do Estado Novo, em 1937, geraram uma grande repressão sobre o movimento operário brasileiro, inclusive nos sindicatos de orientação anarquista, eliminando qualquer possibilidade de sobrevivência desse sindicalismo. Para Araújo (1994), essa intervenção do Estado nos sindicatos e a repressão seguida à Intentona Comunista significaram "a derrota da proposta sindical libertária que, desde o Estado Novo, não encontrou mais condições de reagrupar-se e voltar a influir no movimento sindical" (Araujo, 1994, p.190).

É importante frisar que, mesmo com o total esvaziamento dos sindicatos de orientação anarquista, essas entidades, em momento algum, aceitaram as diretrizes estatais ou alguma estratégia sindical que passasse pelo reconhecimento da legislação sindical vigente.

28 Para Antunes (1982), esse enfraquecimento dos sindicatos de orientação anarquista na década de 1930 está diretamente ligado ao processo de intervenção estatal nos sindicatos, visto a tendência ser contrária a qualquer participação oficial, ao contrário dos comunistas e dos trotskistas. Com a formação da ANL (Aliança Nacional Libertadora), os anarquistas perdem mais espaço no sindicalismo, pois "numa conjuntura liberalizante, onde afloram as tendências explicitamente políticas - comunistas e socialistas na ANL e integralistas na AIB - o anarcossindicalismo, aí sim, desestruturou-se enquanto força operária" (Antunes, 1982, p.106-107). 


\subsubsection{Os sindicatos comunistas e os de orientação trotskista}

Os sindicatos comunistas e os de orientação trotskistas, embora rivais na arregimentação dos trabalhadores, possuíam uma ação sindical semelhante, fosse na organização interna, com a predominância do centralismo democrático, ou na postura perante a intervenção estatal, já que ambos, se num primeiro momento refutam essa presença oficial, posteriormente iriam aceitar participar do sindicalismo oficial.

O Partido Comunista surgiu em 1922 no Brasil, tendo como primeiros participantes antigos militantes do sindicalismo-revolucionário. No final da década de 1920 e início da década de 1930, já tinha expressiva participação nos meios sindicais, procurando arregimentar uma parte dos sindicatos de orientação anarquista.

Uma dessas disputas entre anarquistas e comunistas pela direção da União dos Artífices em Calçados foi assim relatada nos prontuários do Dops:

Está marcada para o dia 13 do corrente uma reunião dos sapateiros. Essa reunião será muito agitada devido ao assunto de que tratará. Os anarquistas querem expulsar da União dos Artífices em Calçados todos os comunistas. Estou informado de que vários elementos comunistas querem fazer força para derrotar a intenção de anarquistas. (Relatório enviado em 11 de fevereiro de 1933. Pront 1123- Sindicato dos Operários Metalúrgicos, v.1, Dops)

Diante da maior ação estatal nos sindicatos, os comunistas, num primeiro momento, lutam pela unidade e autonomia sindicais, questionando veementemente essa intervenção. Num artigo publicado no jornal Nossa Voz, órgão oficial do Partido Comunista, os comunistas perguntavam, "Pode o Ministério do Trabalhador defender os interesses proletários?", e respondiam categoricamente criticando 
essa intervenção, demonstrando o caráter patronal que a lei tinha, comprometendo as futuras lutas da classe operária. Diziam:

O Ministério do Trabalho foi criado para exercer o controle dos sindicatos com o único objetivo de, através de uma série de enganos e manobras, facilitar aos patrões a realização de sua política de diminuição de salários, de aumento de horas de trabalho, para não cumprirem as leis que favorecem os trabalhadores. (Jornal Nossa Voz apud Antunes, 1982, p.109)

Embora refratários à intervenção estatal, os comunistas a partir de 1933 e 1934 perceberam que negar totalmente a ação estatal e alguns benefícios dela surgidos, como faziam peremptoriamente os sindicatos de orientação anarquista, traria enormes prejuízos à sua organização.

Assim, aos poucos vão aceitando que seus sindicatos peçam a carta de reconhecimento ao Ministério do Trabalho, Indústria e Comércio e também começam a disputar internamente os sindicatos oficiais atuando como oposição operária. Araújo (1994) relata a presença comunista em alguns sindicatos reconhecidos pelo governo nos estados de Minas Gerias, São Paulo e Rio de Janeiro

Em São Paulo, além de manterem sua predominância na União Beneficentes dos Empregados em Hotéis e uma minoria sindical importante no Sindicato dos Profissionais Volantes, associações que permaneceram autônomas recusando a oficialização, eles conseguiram formar grupos de oposição atuantes nos seguintes sindicatos reconhecidos: Sindicato dos Bancários, Sindicato Unitivo da Central do Brasil, Sindicato dos Operários Metalúrgicos, Sindicato dos Ferroviários da Estrada de Ferro Sul de Minas (Cruzeiro), Sindicato dos Condutores de Veículos de Santos e Sindicato dos Estivadores de Santos. (Araújo, 1994, p.215)

No caso de ser oposição nos sindicatos oficiais, nem sempre conseguiam divulgar as suas ideias sem sofrerem algum tipo de re- 
presália. Foi o que ocorreu no Sindicato dos Operários Metalúrgicos, quando da formação de uma nova diretoria:

A assembleia resolveu que se elegesse uma diretoria provisória até que se aprovem os novos estatutos - e resolveu também expulsar alguns elementos considerados como representantes comunistas e, portanto, prejudiciais ao meio operário. (Relatório enviando ao delegado do Dops em 09/1/1936. Pront 1123 Sindicato dos Operários Metalúrgicos, v.1, Dops)

Apesar de entrarem nos sindicatos oficiais como forma de empreender uma luta contra o processo de intervenção estatal e de almejarem uma unidade sindical autônoma, os comunistas, ao conquistarem algumas dessas entidades, contribuíram para que o processo de reconhecimento se estendesse e, em contrapartida, os sindicatos autônomos se extinguissem. Como comenta Araújo (1994),

Nesse sentido, sua atuação nos sindicatos oficiais mostrou-se uma faca de dois gumes. De um lado, permitiu que esses sindicatos se politizassem e se engajassem na luta pela autonomia frente ao Estado, ameaçando a concretização do projeto sindical do governo. De outro, ao possibilitar o crescimento do número de sindicalizados e o fortalecimento desses sindicatos em detrimento das entidades livres, ele contribuiu para a criação das condições que inviabilizaram as propostas de sindicalismo autônomo e para a alteração da correlação de forças de modo favorável ao projeto corporativo. (Araújo, 1994, p.218)

No caso dos trotskistas, a sua força principal estava na cidade de São Paulo, formada por intelectuais que desde 1928 tinham rompido com o Partido Comunista. Essa tendência sindical tinha menor expressão que a comunista e a anarquista e sua influência principal ocorreu na União dos Trabalhadores Gráficos (no Rio e em São Paulo) e num curto período (1933-1934) no Sindicato dos 
Bancários de São Paulo. O percurso tomado pelos trotskistas, em certa medida, tem semelhança com as diretrizes dos comunistas. Num primeiro momento, combatem a intervenção do Estado, mas, a partir de 1933-1934, com os sindicatos autônomos perdendo filiados para os oficiais, por não conseguirem o cumprimento das leis trabalhistas pelos patrões, alteram significativamente a política de não concordância da intervenção estatal e aceitam as propostas governamentais.

Um dos casos mais significativos ocorreu com a União dos Trabalhadores Gráficos do Rio de Janeiro. Entendendo que havia uma possibilidade de influenciarem as diretrizes do Ministério do Trabalho, já que não havia ainda a formação de uma burocracia ideológica consistente, os trotskistas começam a incentivar o reconhecimento dos seus sindicatos.Para tanto, pedem, em 1934, o fechamento do Sindicato dos Gráficos do Rio de Janeiro (UTG), e a unificação com a União dos Trabalhadores do Livro e Jornal-sindicato oficial que até então era criticado por esses sindicalistas (Araujo, 1994). ${ }^{29}$

A incorporação dos sindicatos trotskistas ao modelo oficial, para Araujo (1994), demonstra os efeitos que a política de intervenção estatal trouxe para o sindicalismo mais combativo que aceitou participar dessa estrutura estatal: subordinação de parte dos militantes operários às políticas de Estado, favorecendo uma maior adesão dos trabalhadores a essa proposta (visto a confiabilidade que esses sindicalistas poderiam ter perante a classe operária), e a total exclusão daqueles que eram reticentes e lutavam por maior autonomia.

Se em fins de 1933, os trotskistas procuravam unificar o movimento sindical de São Paulo criando a Coligação dos Sindicatos Proletários, lutando por um sindicato por indústria e pela autono-

29 Araujo (1994), apoiando-se no trabalho de Hadler (1982), aponta que, em 1935, já com o reconhecimento do sindicato dos gráficos pelo Estado, "a defesa da legalidade foi assumindo paulatinamente 'proporções mais explícitas e comprometedoras com a política oficial' e o jornal da entidade foi se transformando em instrumento do "processo de subordinação político-ideológico da categoria pelo Estado” (Araújo, 1994, p.132). 
mia sindical, em 1935, já com o reconhecimento de alguns de seus filiados pelo Estado, a ideia de unificação sindical é abandonada nos moldes trotskistas e a própria Coligação é extinta. Ao analisarmos a presença dessas tendências no sindicalismo brasileiro pós-1930, percebemos que o processo de construção de um Estado corporativo, com seus mecanismos de instituição de uma legislação sindical e trabalhista, aos poucos minou o poder de atuação delas.

Enquanto os sindicatos de influência anarquista já em 1935 não tinham qualquer participação efetiva no movimento operário, por não aceitarem nenhuma das determinações corporativistas, os comunistas e os trotskistas, ao aceitarem, ficaram em uma posição pouco confortável para defender a autonomia sindical. Pensando que poderiam de alguma forma barrar, mesmo que minimamente, as investiduras estatais, esses sindicatos, ao aceitaram grande parte da nova legislação sindical e trabalhista, conquistaram alguma representatividade no sindicalismo brasileiro como oposição à diretoria oficial.

Entretanto, após o levante de novembro de 1935, perpetrado pela ANL, para Antunes (1982), "deu-se a desmobilização do movimento sindical: os sindicatos foram fechados e as organizações intersindicais dissolvidas, assistindo-se então à perda da autonomia sindical" (Antunes, 1982, p.115).

Com isso, apenas a estrutura sindical estatal continuou existindo e tanto comunistas e trotskistas, que tentaram mudanças de dentro dos sindicatos, como os sindicatos de orientação anarquista, reticentes a quaisquer intervenções, foram alijados ou tiveram que se submeter a esse sindicalismo corporativista. 


\section{5 \\ AS TERRITORIALIDADES DOS SINDICATOS E A AÇÃO ESTATAL NOS ANOS DE 1930}

As grandes mudanças socioeconômicas e políticas pelas quais o país passou no início da década de 1930 e que marcaram os anos seguintes de sua história foram um processo que, como vimos, trouxe uma maior intervenção do Estado na sociedade civil, procurando controlar, por meio de decretos, as várias instituições democráticas, instaurando novas políticas territoriais e também arbitrando as relações entre o capital e o trabalho.

Ao assumir o governo, Getúlio Vargas realizou marcadamente uma centralização do poder, promulgando o decreto n.19.398 em 11 de novembro de 1930. Por esse decreto, o Governo Provisório ${ }^{1}$ dissolvia o poder legislativo, inclusive as casas legislativas estaduais e municipais $\left(\operatorname{art} .1^{\circ}\right.$ e $4^{\circ}$ ), nomeava interventores nos estados, sendo que os prefeitos, nomeados pelos interventores, exerceriam a função de legisladores também $\left(\operatorname{art} .11^{\circ}\right)$. Além disso, restringia as liberdades individuais explicitamente ao afirmar que ficavam suspensas as garantias constitucionais e qualquer ato desse governo não seria passível de apreciação judicial $\left(\operatorname{art} .5^{\circ}\right) .^{2}$

1 O Governo Provisório (1930-1934) foi o período marcado pela tomada do poder por Getúlio Vargas (novembro de 1930) até a promulgação da Constituição de 1934. Nesse período, a Constituição de 1891 deixou de reger o país, possibilitando que as ações governamentais não tivessem nenhum tipo de marco regulatório maior.

2 Esse decreto encontra-se em <http://www6.senado.gov.br/legislação/ListaPublicacoes.action? id=37246>. Acesso em: 13/5/2011. 
Independente de as esferas legislativas contemplarem ou não os anseios da maior parte da população brasileira, essa ação estatal, por si só, extinguia a presença de um controle institucional (parlamento) sobre o Governo Provisório, tornando-o autoritário. Além desse controle sobre as administrações municipais e estaduais, o novo governo procurou intervir de forma mais direta nas relações entre o capital e o trabalho, criando, em 26 de novembro de 1930, o Ministério do Trabalho, Indústria e Comércio, que passa a ter a incumbência de, nas palavras do próprio Getúlio Vargas (apud Bernardo, 1982, p.84), "substituir a luta de classes negativista e estéril, pelo conceito orgânico e justo de colaboração entre as classes”.

A criação de uma pasta governamental voltada à organização da indústria e do comércio, denotando a preocupação de uma ação estatal mais contumaz nesses setores econômicos, permitiu também que o Estado, a partir desse momento, realizasse uma maior investidura sobre as entidades sindicais. Com isso, tinha-se o objetivo de enfraquecer um movimento sindical de grande expressão e combatividade nas décadas anteriores (como os sindicalistas-revolucionários e os comunistas), transformando as entidades sindicais, a partir desse momento, em simples órgãos de defesa e colaboração com o poder público.

Desta forma, o Estado impunha seu modelo sindical, assumindo o ato de organizar as entidades, o que até então era atribuição dos trabalhadores, anulando a organização mais horizontal dos sindicalistas-revolucionários e substituindo-a pela obediência ao poder.

Essa ação estatal tinha também como prerrogativa limitar as ações territoriais dos sindicatos, que graças a sua autonomia, apareciam como elementos perturbadores dessa nova ordem e, por isso, foram um dos principais alvos dessa política.

Esse processo de maior interferência realiza-se com a promulgação do decreto-lei n.19.770, de 19 de março de 1931, conhecido como lei de sindicalização. Com ela, o governo implantava a unicidade sindical, a necessidade de reconhecimento dos sindicatos pelo poder público, estabelecendo um sistema legal de representação entre os trabalhadores, no qual lentamente essas entidades deixavam de ser 
órgãos de resistência para transformarem-se em entidades privadas de função, quase que limitadas ao assistencialismo.

Como aponta o próprio Getúlio Vargas, o processo de intervenção do Estado sobre os sindicatos teve como objetivo

transformar o proletariado numa força orgânica de cooperação com o Estado e não o deixar pelo abandono da lei, entregue à ação dissolvente de elementos perturbadores, destituídos dos sentimentos de pátria e de família. (Getúlio Vargas apud Antunes, 1988, p.74)

Concordando com Getúlio Vargas, Oliveira Vianna, consultor jurídico do Ministério do Trabalho, era ainda mais claro acerca do real intuito da investidura estatal nos sindicatos: minar o poder dos sindicatos mais revolucionários. Numa de suas obras sobre a questão sindical, o autor afirmava

O primeiro princípio orientador da nossa política sindical é o da deliberada e taxativa dissociação deste binário histórico, característico das organizações sindicais dos velhos povos europeus - o binário "sindicalismo-socialismo". [...] Daí vem que nosso sindicalismo, ao contrário, é profissional, corporativo, cristão. (Viana, 1951, p.79-81)

Esse decreto-lei possibilitou uma maior fragmentação da classe operária. Gerou divisões no seio de várias categorias dos trabalhadores, desejosos de terem reconhecidos suas entidades e, por extensão, receber algumas garantias prometidas pelo Estado, separando os operários em entidades divergentes.

Ao contrário do que poderia ocorrer antes de 1930, quando os operários buscavam o entendimento no caso de se ter uma divisão categorial por base territorial, como era o Estado o fomentador dessas rivalidades, tais separações territoriais trouxeram enormes prejuízos para a organização sindical.

Como analisou Antunes (1988), 
Ou seja, o particular nesse processo é que foi o Estado quem criou "sindicatos oficiais" como forma de minar o sindicalismo autêntico. E o fez através de uma prática dupla, onde, além da repressão sobre os setores organizados da massa assalariada e seus sindicatos, desencadeou uma política de manipulação junto ao contingente operário. (Antunes, 1986, p.113)

\section{1 - Os sindicatos de orientação anarquista e a intervenção estatal-corporativa}

Ao propiciar a criação de sindicatos entre as várias categorias existentes, sendo algumas delas de grande expressividade no período, o Estado lentamente vai subordinando cada categoria a uma base territorial local específica. Isso ocorria porque surgiam sindicatos em várias localidades, algumas inclusive limítrofes, com o claro intuito de apenas obterem os benefícios propostos pela intervenção estatal. Mesmo assim, as entidades de classe de caráter revolucionário, até pelo menos meados da década de 1930, iriam resistir ao assédio governamental.

Como afirma Antunes (1988, p.84),

A resistência do movimento sindical autonomista às normas oficialistas estabelecidas pelo decreto n.19.770 pôde claramente mostrar que houve fracasso na política sindical varguista na primeira metade da década de 1930.

Essa parcela de sindicatos contrária à lei de sindicalização tinha características anarquistas, totalmente contrárias à presença estatal entre o sindicalismo brasileiro. Os sindicatos de orientação anarquista consideravam que a criação do Ministério do Trabalho e a promulgação do decreto-lei n.19.770 tinham como objetivo "subordinar mais ainda o operariado, pois pretende controlar todo o movimento renovador que vise à nossa emancipação" (Natalino Rodrigues, secretário-geral da FOSP apud Antunes, 1988, p.105). 
No início do processo de intervenção estatal, os sindicatos de orientação anarquista ainda conseguiam resistir e promover a formação de uma federação sindical (a FOSP), tendo inclusive a presença de um sindicato de orientação trotskista, a União dos Gráficos de São Paulo. Em 1931, como forma de consolidar novamente a Federação Operária de São Paulo, ocorreu a $3^{a}$ Conferência Operária Estadual, com a participação de 18 sindicatos, sendo 10 da capital e 8 do interior.

Tabela 5 - Entidades participantes da $3^{\mathrm{a}}$ conferência operária estadual

\begin{tabular}{ll}
\hline \multicolumn{1}{c}{ Local de Origem } & \multicolumn{1}{c}{ Entidade } \\
\hline São Paulo & União dos Canteiros \\
& Liga Operária da Construção Civil \\
& Sindicato dos Manipuladores de Pão \\
& Sindicato dos Vidreiros \\
& União dos Artífices em Calçados \\
& União dos Operários Ladrilheiros \\
& União dos Operários Metalúrgicos \\
& União Sindical dos Profissionais do Volante \\
& União dos Trabalhadores Gráficos \\
& União dos Trabalhadores da Light \\
Carvalho Araújo & União de Canteiros \\
Itatiba & União de Canteiros \\
Ribeirão Preto & União de Canteiros \\
Ribeirão Preto & Centro Operário \\
São José dos Campos & Centro Operário \\
Sorocaba & Grupo Operário \\
Catanduva & Núcleo Proletário \\
Bauru & União Gráfica \\
\hline
\end{tabular}

Fonte: Amir El Hakim de Paula apud Azevedo (2002).

Embora a Tabela 5 demonstre uma grande concentração de entidades na cidade de São Paulo, a reunião teve grande ressonância nos meios sindicais, sendo que os trotskistas propuseram a união dos seus sindicatos com os sindicatos anarquistas, pedido esse negado 
pelos sindicatos de orientação anarquista que não concordavam com as táticas dessa tendência marxista, sendo acusados então como adeptos do divisionismo ${ }^{3}$ (Azevedo, 2002).

Para os sindicatos de orientação anarquista, a lei de sindicalização feria o princípio de autonomia, sendo então considerada 'fascista' e, portanto, peremptoriamente, deveria ser combatida. Não raro, nas páginas de seus jornais, esses sindicatos atacavam os efeitos da investidura estatal e a 'farsa' desse novo modelo sindical. ${ }^{4}$

Um exemplo de luta contra o desmantelamento desses sindicatos mais combativos foi a de parte dos trabalhadores em fábricas de chapéus, que condenaram a criação de outra entidade de defesa da categoria, apontando-a como sindicato amarelo. ${ }^{5}$ Para o jornal $O$

3 Embora trotskistas e anarquistas combatessem até esse momento o projeto sindical do Estado, inúmeras divergências separavam-nos, seja na negação do partidarismo (caso dos anarquistas) ou do federalismo (caso dos trotskistas). Algumas dessas divergências eram expressas em seus panfletos. Num deles, os trotskistas atacavam tanto os anarquistas como os comunistas. "Na luta contra a polícia e contra os patrões apenas estão na vanguarda do movimento os combatentes da esquerda comunista. Os outros, os anarquistas e comunistas de direita não passam de elementos policiais e patronais." Panfleto intitulado Ao Proletariado e ao Povo em Geral, da Esquerda Communista. Pront 716, FOST, v.1, abr. 1932.

4 Como afirma o jornal O Trabalhador da Light, de janeiro de 1934, sobre a intervenção estatal: "Esses politiqueiros compreenderam que os trabalhadores brasileiros já representam uma força, cuja força, arregimentada e controlada pelo Estado, podia representar uma arma e um aliado potente nas mãos dos revolucionários outubristas [...]. Assim os pseudossociólogos e economistas da Nova República estudaram a carta Del Lavoro da Itália e o sindicalismo fascista. [...]. Os politiqueiros da ditadura com o monstruoso decreto-lei n.19.770 criaram a lei de sindicalização que além de ser contra o livre pensamento, e de negar a luta de classes, a mesma é fascista e chauvinista" (O Trabalhador da Light apud Azevedo, 2002, p.299).

5 Os sindicatos amarelos eram os sindicatos formados por patrões ou com o apoio dos patrões visando dividir a classe operária e dotá-la de um espírito conciliador. A denominação de amarelos vincula-se à fama dos orientais no movimento operário europeu, visto pelos demais como "fura-greves", sabotadores do movimento e colaboradores com os patrões. A expressão já existia no século XIX na França, aplicada então pelos anarquistas adeptos do sindicalismo-revolucionário. 
Trabalhador, FOSP, entidade que congregava os chapeleiros contrários ao processo de sindicalização estatal, então organizados no Sindicato dos Operários em Fábricas de Chapéus,

Um grupo de inconscientes fundou em Vila Prudente um sindicato amarelo de chapeleiros, tendo à frente dois indivíduos intrusos na classe: um ferroviário e um mestre-escola do arrabalde [...]

O fundamento invocado pelos intrujões é que o nosso Sindicato não está reconhecido nem legalizado. Esquecem esses senhores, entretanto, que o SOFC está devidamente reconhecido pelos chapeleiros conscientes.[...]

O tal sindicato amarelo não conta com mais de 30 indivíduos [...] que vão para dentro das fábricas por um mesquinho salário com o intuito premeditado de desmoralizar a indústria do maior centro industrial da América do Sul. (O Trabalhador, 1932, apud Azevedo, 2002, p.303)

A divisão da categoria, com o reconhecimento oficial de uma delas, propiciaria um maior controle das ações dos operários, tanto pelo empresariado quanto pelo Estado, pois, primeiro, a categoria sairia enfraquecida do processo e, segundo, a organização interna e, consequentemente, sua ação territorial seriam determinadas pelo governo.

Desta forma, a luta desses sindicalistas para manter sob sua influência vários sindicatos foi enorme, pois, conforme o processo de intervenção avançava, novos sindicatos surgiam e solicitavam o reconhecimento estatal. E, se alguma greve teve impacto nesse período, ela já não tinha a força de trazer os trabalhadores de outras categorias para a formação de uma greve de solidariedade, como vimos no Capítulo 3.

Mesmo assim, no período de 1931 a 1935, Azevedo (2002) registrou a presença de inúmeras greves dirigidas por esses sindicatos, sendo que a dos ferroviários em 1934 foi classificada como "greve geral" pelo fato de envolver operários de diversas cidades do estado de São Paulo, como Sorocaba, Assis, Bauru, Ourinhos e São Carlos, mas também em cidades de outros estados, como Mineiros, em Goiás. 
Essa greve recebeu atenção de grande parte do governo, sendo que as polícias desses estados intervieram no movimento, ocorrendo o fechamento de sindicatos e prisão dos sindicalistas. Entretanto, diferentemente do que poderia ocorrer até o fim da década de 1920, na qual a intervenção estatal na organização sindical era de outro tipo, o movimento ficou restrito aos trabalhadores da ferrovia.

Aos poucos, as entidades combativas eram minadas pelo constante assédio estatal, fosse pela concorrência dos sindicatos oficias, fosse pela maior ação policial. ${ }^{6}$ Esse fato fez que os sindicatos de orientação anarquista lentamente fossem perdendo a sua força e que os sindicatos comunistas e trotskistas, ${ }^{7}$ como vimos, mudassem a sua estratégia.

Como bem aponta Azevedo (2002),

O relativo sucesso da sindicalização oficial só teria sido alcançado, inicialmente, pela adesão de trabalhadores que já teriam afinidades com a máquina governamental - os chamados "amarelos” - principalmente no Rio de Janeiro. Seguiu-se, após 1933, a estratégia de atuação dos comunistas que, ao não conseguir fundar novos sindicatos em São Paulo, sob a sua orientação, nem transformar os sindicatos anarquistas, dirigem suas energias para a criação de minorias nos sindicatos oficiais. Por fim, foram os trotskistas

6 Várias dessas entidades foram alvos constantes das ações policiais, como ocorria anteriormente na vigência do Estado liberal. Entretanto, agora essas ações tinham a coordenação de uma polícia política, o Dops.

7 Essa postura seria condenada pelos sindicatos de orientação anarquista, por meio de seus semanários. No jornal A Plebe, por exemplo, a decisão da UTG (União dos Trabalhadores Gráficos) em se oficializar levou a um grande repúdio: “o representante gráfico fez peremptória declaração de que a União dos Trabalhadores Gráficos irá até a sindicalização oficial, para não perderem eles, os orientadores, o controle das 'massas' gráficas. Quer dizer: políticos como são, raposas como todos os outros políticos, não têm nenhum escrúpulo em submeter os trabalhadores da enorme corporação, cujo passado na história do proletariado é cheio de lances magníficos de luta, ao jugo do Ministério do Trabalho e, consequentemente, aos interesses do patronato (A Plebe, 1934, apud Azevedo, 2002, p.305). 
que optaram por essa estratégia para a obtenção das férias, nos sindicatos que atuavam.

\section{E completa esse raciocínio afirmando que}

Ficaram as associações anarquistas isoladas nos sindicatos de sua federação, defendendo a autonomia que era afirmada radicalmente sob seus princípios, preferindo fechar suas portas a participar da farsa imposta aos trabalhadores. (Azevedo, 2002, p.307)

O enfraquecimento da prática anarquista é mais evidente a partir de 1935, com sua presença circunscrita apenas a alguns sindicatos paulistas. Já não mais havia a organização nacional que os sindicalistas das duas primeiras décadas alcançaram, pois eles perdiam espaço para os sindicatos de orientação comunista e trotskista.

Entretanto, não podemos imputar as dissensões ocorridas na década de 1920, com o surgimento do Partido Comunista, como o principal motivo dessa decadência. Azevedo (2002) comenta em sua pesquisa alguns pontos que ajudariam a compreender o enfraquecimento das propostas anarquistas entre os operários. Dentre eles, a autora aponta a concorrência de outras tendências não libertárias nos sindicatos, a ingerência estatal, a repressão policial se utilizando de tortura, perseguições e, no caso de estrangeiros, culminando com a deportação do militante e a adesão de alguns militantes anarquistas ao Partido Comunista, desiludidos com a prática descentralizada e autogestionária dos sindicatos.

Pelo exposto acima, percebemos que inúmeros fatores desencadearam o enfraquecimento das práticas anarquistas no sindicalismo brasileiro. As ações policiais, por exemplo - marca registrada na vigência do Estado liberal, com as prisões, o fechamento das sedes operárias, o empastelamento dos jornais operários -, continuaram a vigorar com a mudança do modelo estatal. Com o Estado corporativo, as ações nos sindicatos baseavam-se num objetivo mais palpável: quanto mais se enfraquecessem as organizações operárias combativas, mais o projeto de intervenção ganharia força. 
E a forma usada diferenciava-se da anterior, presente no regime liberal: combater sem piedade as organizações sindicais, por um lado, e assediar as massas trabalhadoras com garantias sociais, por outro. Essa mescla de repressão policial com garantias sociais estatais foi um grande provocador da decadência anarquista. E, quase no fim de sua existência, esses sindicatos, já prevendo o futuro de suas entidades, continuavam a não abrir mão de acreditar nos seus valores ideológicos:

Não tememos a reação porque a Federação Operária de São Paulo, mesmo sendo obrigada a cerrar as suas portas, vive na consciência dos trabalhadores organizados. (A Plebe, 1933, apud Azevedo, 2002, p.307)

A importância da organização do Partido Comunista nos sindicatos, se não teve um papel primordial nessa decadência anarquista, ao dividir os sindicatos mais combativos, facilitou o caminho da intervenção estatal. ${ }^{8}$ Em sua maioria egressa do sindicalismo-revolucionário, esses militantes, como que querendo sepultar seus passados, iniciaram uma batalha contra os sindicatos-revolucionários, bem como contra as convicções que ainda perduravam em si mesmos.

Alguns deles, formadores do Partido Comunista no Brasil, foram expulsos da agremiação ainda bem no início da formação da entidade. O caso de Antonio Canellas é exemplar. Militante anarquista e depois comunista, foi enviado a uma reunião da III Internacional, em Moscou, como representante do PCB, procurando, entre outras coisas, o próprio reconhecimento da entidade diante das instâncias superiores.

Ao participar de algumas seções de debates, inclusive pedindo um aparte para Trotsky, Canellas se incomoda com a presença do centralismo democrático nesses encontros, demonstrando internamente a forte presença de um anarquismo que queria a todo custo

8 Sobre essa divisão e enfraquecimento dos sindicatos mais combativos, veja-se a análise de Zaidan Filho (1988). 
sufocar. Criticando a forma da realização dos debates, Canellas angaria descontentamentos entre os participantes, culminando, inclusive, com a negativa da III Internacional em reconhecer o partido brasileiro como membro efetivo da entidade.

Chegando ao país, Canellas é repreendido pelos membros do Comitê Central do PC brasileiro, sendo expulso em 1924. ${ }^{9}$

A tentativa de depuração das ideias anarquistas do Partido Comunista ainda levaria certo tempo. Como Astrogildo Pereira demonstra, no III Congresso do Partido Comunista, de 1928,

Em sua maioria os camaradas que militam nos sindicatos ainda estão impregnados pelo espírito corporativista, localista, autonomista, resíduos do anarcossindicalismo. [...] Esse estado de espírito é que se torna urgente combater encarniçadamente. (Pereira, 1976, p.148)

Por essas palavras, fica claro que a luta contra os anarquistas foi constante, inclusive internamente, já que ambos estavam disputando os mesmos sindicatos. E, enquanto comunistas e anarquistas lutavam pela supremacia entre os sindicatos mais combativos, várias entidades de trabalhadores aceitaram sem muitos questionamentos a nova lei que lhes tirava a autonomia, enquanto outras já surgiram baseadas na nova legislação.

Eram entidades ligadas geralmente aos serviços comerciais e bancários, com menor experiência de luta sindical, e procuravam se atrelar às determinações oficiais como maneira de conseguir o reconhecimento patronal. Esse foi o caso do Sindicato dos Bancários de São Paulo, que pediu a oficialização de sua entidade para ser aceito pelos patrões como representante da categoria (Antunes, 1982).

A ação do Estado procurando controlar os sindicatos, bem como o surgimento de várias entidades de classe patrocinadas pela nova lei, possibilitou que os sindicatos de trabalhadores tivessem uma área de atuação menor do que as entidades representativas do patronato, dificultando a sua ação sindical no território. Entender

9 Mais detalhes sobre a biografia de Antonio Canellas, ver Salles (2005). 
esse processo avançado de controle do Estado sobre a organização operária e suas repercussões, no que tange à questão territorial, será a nossa preocupação nas próximas páginas.

\section{2 - Os efeitos da legislação sindical sobre a ação territorial dos sindicatos oficiais}

A primeira parte deste capítulo demonstrou o enfraquecimento dos sindicatos mais combativos, sendo que aqueles que não desapareciam completamente tinham que se adaptar à legislação sindical. Entretanto, os sindicatos que não tinham uma ideologia definida (conhecidos como "amarelos") aceitaram a intervenção estatal e passaram a ser reconhecidos como "legítimos" representantes da categoria.

Os sindicatos reconhecidos pelo Estado, consequentemente, tinham que aceitar as diretrizes da legislação sindical vigente, dentre elas, aquelas que se referiam à ação territorial. E, fazendo isso, o Estado corporativo buscava formas de controlá-los quase que totalmente.

Para melhor entendermos como essa política se desenvolveu no país, a partir desse momento, discutiremos as análises de Oliveira Vianna sobre a importância do sindicato numa sociedade dominada pelo Estado corporativo. Em um de seus textos, ao comentar sobre a política sindical desse período, Vianna (1943) demonstra seu objetivo: nacionalizar ao máximo as entidades de trabalhadores para que, assim, "depuradas" de quaisquer resquícios combativos, possam ser utilizadas como órgãos de apoio ao Estado.

O nosso problema está em não reagir contra elas, mas tomar essas instituições em nossas mãos, encará-las com decisão e coragem, e alterá-las, deformá-las, abrasileirá-las, em suma, de maneira a ajustá-las ao nosso corpo, à nossa conformação, às dimensões das nossas possibilidades. (Vianna, 1943, p.XII, itálico do original)

O sindicato nessa visão deve ter uma única função: servir aos interesses do Estado, ou seja, o sindicato deve existir enquanto correia 
de transmissão do Estado a bem de seus serviços públicos (Vianna, 1943). Nesse sentido, as leis sindicais devem ter dois objetivos: diminuir gradativamente a influência dos sindicatos combativos e abrir a oportunidade de os sindicatos reformistas ditos amarelos serem reconhecidos.

Para o magistrado e um dos principais interlocutores do Estado em relação aos sindicatos, a não opção pelos sindicatos combativos é clara. Era preciso alcançar uma maior visibilidade para aquelas entidades que, de certa forma, tinham uma sintonia maior com esse planejamento. Ao comentar sobre a importância da legislação sindical, no que tange à questão territorial, Oliveira Vianna demonstra claramente o significado de seus efeitos: dividir ao máximo os sindicatos de trabalhadores e a sua base territorial.

Tendo em consideração a necessidade de enfraquecer as lutas dos sindicatos dos trabalhadores, Oliveira Vianna demonstra que, enquanto esteve trabalhando diretamente no governo, preocupou-se em fragmentar esses sindicatos ao máximo, propiciando uma quase que total atomização dessas categorias.

De minha parte, como consultor do Ministério do Trabalho, sempre me opus à formação aqui dos sindicatos por indústria [...] Minha orientação sempre foi no sentido dos sindicatos pequenos, isto é, dos sindicatos por "categorias" e, principalmente por "ofícios", permitindo mesmo, nos sindicatos formados de profissões conexas, a sua subdivisão em grupos menores de profissões similares ou idênticas, até o limite do razoável. Toda a minha exegese do decreto n.19.770 de 1931 foi conduzida neste sentido e penso com isto ter servido grandemente os interesses do Brasil. Sob esse critério - dos sindicatos por ofício, e não sindicatos por indústria -, é que organizamos toda a nossa estrutura sindical e estamos preparando as bases para a futura articulação corporativa. (Vianna, 1943, p.53-54)

Além disso, preocupou-se em delimitar a esses sindicatos bases territoriais mínimas, para que essa ação sindical ficasse restringida quase sempre a um município. Assim, sua interpretação seria a de 
que os sindicatos deveriam ser pequenos e com base territorial local, obstando assim, quem sabe, as ações dos sindicatos dos trabalhadores perante uma greve mais generalizada, como as de uma categoria.

Não só temos reduzido a "competência profissional", isto é, o número de "ofícios" abrangidos por cada um dos sindicatos, como também temos reduzido a sua 'competência territorial', isto é, a área de sua jurisdição.

Pequenos sindicatos especializados, monopolizando a defesa da classe dentro de pequenas áreas: este foi o meu pensamento ao interpretar o decreto 19.770 de 1931. Este, felizmente, parece ser também o pensamento que até agora vem orientando o processo da nossa estruturação sindical. (Vianna, 1943, p.53-54, grifo nosso) ${ }^{10}$

Oliveira Vianna explicita as intenções do Estado: transformar os sindicatos de trabalhadores em pequenos agrupamentos, preocupados apenas com os interesses de cada ofício, diminuir a visão de classe social e reduzi-los a uma base territorial cada vez menor. Essa proposição é totalmente contrária às diretrizes que os sindicatos-revolucionários defendiam desde o seu primeiro congresso em 1906.

Analisando as resoluções desse congresso, duas propostas demonstram o que dizemos acima.

A Confederação Operária Brasileira organizada sobre as presentes bases de acordo tem por fim:

(...)

Estreitar os laços de solidariedade entre o proletariado organizado, dando mais força e coesão aos seus esforços e reivindicações, tanto moral como material;

E mais adiante

10 Esse comentário encontra-se também no Boletim do Ministério do Trabalho, Indústria e Comércio, n.8, abril de 1935, p.122. 
Considerando as diversas condições do proletariado e da indústria, conforme os lugares:

O Congresso aconselha de preferência:

O sindicato abrangendo todos os ofícios, nas grandes empresas ou companhias - quando estes se achem diretamente ligados entre si sob uma mesma administração;

O sindicato de indústria, quando vários ofícios estão estreitamente ligados ou anexos na mesma indústria. (apud Pinheiro, 1979, p.42 e 48)

No primeiro caso, era claro para os sindicalistas que o ofício demonstrava apenas uma situação momentânea de pertencimento e que o importante era perceber-se além do ofício, perceber-se enquanto classe operária. E, no segundo caso, entende-se que, quando possível, os trabalhadores deveriam se unir em um único sindicato por indústria, como forma de propiciar uma melhor maneira de se contrapor ao capital.

Ao determinar a fragmentação dos trabalhadores em sindicatos de ofícios e determinar também uma base territorial diminuta, Oliveira Vianna pretendia enfraquecer o movimento operário. Mas como propor essas proposições limitantes sem ser questionado pelos sindicatos? Para nós, isso é claro: atacando as entidades de classe combativas até que se diminua a sua influência, já que aquelas que aceitaram o processo de oficialização, por lei, deveriam aceitar as prerrogativas que o decreto também demandava.

Mas Oliveira Vianna aponta outro motivo para os sindicatos serem tão fragmentados: o povo brasileiro não estaria preparado para a formação de grandes organismos nacionais.

Ao comparar o sindicalismo brasileiro com o italiano fascista, Oliveira Vianna considera a nossa grande extensão territorial "culpada" pelo nosso "insolidarismo" 11 e, assim, justifica a fragmentação territorial dos sindicatos. Diz o intelectual:

11 Sobre a questão do insolidarismo do povo brasileiro defendida por Oliveira Vianna, Martin (1993, p.187) comenta seus objetivos: "Obsessivamente preo- 
O fenômeno da distância geográfica, que aqui tão profundamente separa, dissocia e isola os indivíduos ou os subgrupos, lá praticamente está eliminado pela densidade mesma da massa social, que vive dentro destes pequenos, reduzidíssimos espaços. O espírito coletivo e público, a circulação da vida espiritual, a variedade e multiplicidade das formas associativas, os espíritos de solidariedade social e profissional adquirem ali expressões absolutamente desconhecidas no Brasil. (Vianna, 1943, p.175)

Importante destacar que, se ao povo brasileiro organizado em sindicatos não era permitido ir além de uma base territorial municipal, o mesmo não ocorria com os patrões. Estes já estavam preparados para ter suas entidades com influência nacional. É assim que Oliveira Vianna defende a ampliação da base territorial dos sindicatos patronais:

O fenômeno das formas de sociabilidade revelando-se numa área de extensão acima da municipal é ainda excepcional em nosso país; em condições de frequência e generalidade, só se mostra possível em certas categorias do grupo empregador ou das profissões liberais.

De certas categorias do grupo empregador - disse. Porque é fora de dúvida que as formas organizadas da grande indústria ou do grande capitalismo industrial não poderiam, em regra, ajustar-se pela sua própria natureza, às dimensões, demasiadamente estreitas, de uma área municipal. Ninguém poderia conceber uma organização sindical sobre bases estritamente municipais (salvo nas metrópoles) de, por exemplo: empresas metalúrgicas, empresas

cupado com a unidade brasileira, aliás como muitos outros pensadores que o antecederam, a originalidade de Oliveira Vianna reside na crença de que os instrumentos teóricos colocados à disposição do cientista social moderno permitiriam por si só construir a solidariedade nacional que tanto nos faz a falta. Tudo dependeria de um bom diagnóstico, capaz de detectar a raiz de nosso 'centrifugismo histórico' e para ele é na imensidão geográfica do país que se localiza a causa principal desta tendência”. 
ferroviárias; empresas de navegação; empresas bancárias; empresas de serviços públicos e outras, de tipo análogo. (Vianna, 1943, p.189)

Ao sindicato patronal era permitida uma área territorial de alcance regional ou até nacional; aos sindicatos de trabalhadores a base territorial deveria ser municipal. E se algum sindicato quisesse ampliar a sua base territorial, seria o governo que referendaria ou não o pedido, com severas críticas ao pedido formulado. ${ }^{12}$ Conforme a intervenção tornava-se mais estruturada, ficava nítida a intenção do governo em limitar territorialmente a ação dos sindicatos de trabalhadores, não ocorrendo o mesmo quando se tratasse de limitar a ação dos sindicatos patronais. Desta forma, a territorialidade dos sindicatos patronais não é a mesma dos sindicatos de trabalhadores. Conforme a ação estatal progride, essas diferenças ficam cada vez mais evidentes.

Em julho de 1934 foi promulgado o decreto n.24.694, que tinha a incumbência de reorganizar as relações entre os sindicatos de trabalhadores. Esse novo decreto surge com a preocupação em desenvolver alguns pontos que estavam sendo apresentados de forma superficial pelo decreto-lei n.19. 770 .

Além disso, num ambiente mais liberalizante proporcionado pela Constituição de 1934, bem como pela pressão de sindicatos católicos, que temiam perder a influência sobre uma parte dos trabalhadores, o Estado permite novamente a pluralidade sindical, só que agora restringida apenas a três representantes por categoria na mesma base territorial. ${ }^{13}$

12 Diz Vianna (1943, p.190), "os sindicatos, a que fossem por ato exclusivo da autoridade admistrativa (em itálico, no original) fixada uma base estadual, se tornariam meras artificialidades e só teriam realmente existência e eficiência nas suas sedes metropolitanas".

13 Como observa Moraes Filho (1978, p.226), no artigo 5º número II, "somente poderiam caber três sindicatos no máximo, em cada profissão. A rigor, viriam a existir unicamente dois, porque dada a exigência de um terço para cada sindicato, dificilmente se daria a divisão ótima desta quantidade para a constituição da nova associação". 
Uma questão marcante no novo decreto era a nova postura do governo com relação à existência das categorias profissionais. Se no decreto-lei n.19.770, o uso da palavra classe para referir-se a uma dada profissão é corrente, nesse novo decreto, no artigo $2^{\circ}$, substituise essa nomenclatura por categoria profissional.

O que poderia ser apenas uma mudança de estilo, na verdade, pode demonstrar uma nova postura com relação à própria organização dos sindicatos. Como vimos anteriormente, Oliveira Vianna teve grande participação na formulação desse decreto e sua visão de sindicato (a que predominou na legislação) leva em consideração a existência de sindicatos por ofício como base para a organização operária.

Ao pontuar a existência de categoria profissional e não de classes na nova legislação, para Costa, S. (1986), o Estado tem claramente uma intenção: demover dos sindicatos a ideia de que pertencem a uma classe específica (como a classe operária), já que estão fracionados em várias entidades. Diz:

Esse cuidado da parte dos redatores do decreto é intencional, na medida em que contribui para a fragmentação dos próprios trabalhadores em categorias profissionais. [...] a utilização do termo categorias profissionais, no novo decreto, em lugar de classe significava, ao nosso ver, especial cuidado para negar a existência de antagonismos sociais, oriundos do próprio conflito capital e trabalho, acompanhando o espírito corporativo da redação deste texto legal. (Costa, S., 1986, p.32-33)

Para o Estado corporativo, os sindicatos não são apenas órgãos de defesa dos trabalhadores, são órgãos de assistência pública. Em vez de se preocupar com a luta contra o capital, deve ser função do sindicato, junto ao Estado, organizar a nova sociedade. A mudança de termo demonstra que o Estado corporativo teria como preocupação incorporar nas mentes trabalhadoras a sua nova missão: abrir mão da luta contra a classe patronal e ser coparticipante num projeto de união nacional. 
Sobre essa mudança de orientação, Oliveira Vianna, consultor jurídico da comissão que elaborou esse decreto, apontava a necessidade de o Estado controlar os sindicatos:

Para que uma política econômica nacional possa ser orientada pelo Estado - é óbvio - faz-se mister que o governo tenha poder para fazer chegar essa orientação às categorias da produção interessadas o que só é possível com o sindicato integrado no Estado, controlado por ele, partilhando da autoridade deste para os efeitos da direção e disciplina interna da própria categoria. (Vianna, 1943, p.13)

Quanto mais se controlassem os sindicatos, mais próximos da proposta governamental estariam e, consequentemente, do projeto de união nacional corporativo. A volta da pluralidade sindical permitida pela Constituição de $1934^{14}$ e ratificada no $2^{\circ}$ artigo desse decreto possibilitava, inclusive, que o Estado facilitasse seu trabalho de enfraquecimento de uma categoria.

Um exemplo é o dos trabalhadores da Light que, como vimos, em 1934 tinham um sindicato que ideologicamente ligava-se à orientação anarquista. Como forma de diminuir a influência dessa tendência nos meios sindicais, e também de ter sob sua supervisão um sindicato de uma categoria importante, o governo utiliza-se do artifício da pluralidade sindical para permitir a criação de outra entidade.

Sindicato da União dos Trabalhadores da Light de São Paulo

O dr. Agamenon Magalhães, Ministro do Trabalho, assinou a carta de reconhecimento do sindicato da União dos Trabalhadores

14 No artigo 120, parágrafo único, da Constituição Federal de julho de 1934, lê-se: "A lei assegurará a pluralidade sindical e a completa autonomia dos sindicatos". Sobre a questão da autonomia Costa, S. (1986, p.34) diz: "Ora, se por um lado a pluralidade sindical estava assegurada, dentro dos limites já assinalados, por outro a autonomia sindical, garantida pelo artigo 120 da Constituição Federal, na verdade era inexistente". 
da Light de São Paulo, entregando-a pessoalmente, em seu gabinete, ao sr. Antonio Machado, presidente do referido sindicato. [...] Baseado, naturalmente, na Constituição que assegura a pluralidade dos sindicatos, o Ministro do Trabalho verificando, pelos documentos remetidos pela União dos Trabalhadores da Light, que essa sociedade possui a maioria dos operários daquela empresa, houve por bem reconhecer o referido sindicato. [...] As comissões da UTL que vieram a esta capital elogiaram as atenções do Ministério do Trabalho. (Boletim do Ministério do Trabalho, Indústria e Comércio, n.2, out. 1934, p.263)

Outra mudança significativa ocorre no $12^{\circ}$ artigo do novo decreto. Isso porque ele explicita claramente as diferenças entre os sindicatos patronais e os de trabalhadores quando se organizassem territorialmente. Os sindicatos de trabalhadores deveriam ser sempre locais, ou seja, sua base territorial só excepcionalmente abrangeria uma área superior à de um município. Em contrapartida, os sindicatos patronais não teriam nenhuma restrição territorial, podendo constituir-se, inclusive, nacionalmente.

Art $12[\ldots]$

$\S 1^{\circ}$ Os sindicatos dos empregadores poderão constituir-se por profissões ou atividades exercidas numa mesma localidade, num mesmo ou em vários Estados ou em todo o país.

$\S 2^{\circ}$ Os sindicatos de empregados serão sempre locais; mas, em casos especiais, atendendo às condições peculiares a determinadas profissões, o Ministério do Trabalho, Indústria e Comércio poderá fixar aos sindicatos respectivos uma base territorial mais extensa.

$\S 3^{\circ} \mathrm{Em}$ qualquer hipótese do $\S 2^{\circ}$, a área fixada ao sindicato deverá coincidir sempre com as das divisões administrativas do Estado ou da União. (Boletim do Ministério do Trabalho, Indústria e Comércio, n.1, set. 1934, p.68)

Ao analisarmos esse decreto, percebemos qual a real consequência de sua promulgação: enfraquecer as ações territoriais das 
entidades de trabalhadores. Se não bastassem esses sindicatos já estarem subordinados a uma gama de leis que lhes tiravam qualquer autonomia organizacional, o Estado, nesse decreto, aponta um controle também sobre suas relações externas.

Com esse decreto, os trabalhadores estariam com enormes dificuldades de se organizarem pelo país, pois suas entidades deveriam ser sempre locais, sendo permitida só em casos excepcionais a formação de um sindicato nacional ou estadual, não se exigindo o mesmo aos sindicatos dos empregadores. Ou seja, ao sindicato dos empregadores, era dada total liberdade de se organizarem pelo país e aos trabalhadores restava apenas contarem com a força local.

A possibilidade de um único sindicato de trabalhadores estar em várias cidades de um mesmo estado, como no caso do Sindicato Estadual dos Chapeleiros da década de 1910, com essa legislação era improvável, já que a máxima instância territorial de um sindicato seria o município. A formação de uma greve estadual dependeria da união de todos os sindicatos locais, o que já traria enormes dificuldades de organização para a classe trabalhadora. Para um evento desse porte ter êxito, dependeria da afinidade entre os vários representantes locais, a presença ou não de uma federação, os interesses locais de cada categoria etc.

O sindicato patronal, ao contrário, sendo um único organismo no estado, poderia monitorar melhor as ações dos sindicatos operários, minando, inclusive, quando se tentasse ampliar um movimento de greve mais generalizada. O processo de intervenção estatal iniciado em 1931 ganha novas nuances com o decreto n.24.694, de julho de 1934.

Como aponta Costa, S. (1986),

Neste caso, portanto, fica patente a intenção de limitar, em termos territoriais, a organização sindical dos trabalhadores, reduzindo a possibilidade da formação de um sindicato mais forte, com um poder de barganha maior. (Costa, S., 1986, p.36)

Cabe ressaltar que o Estado, preocupando-se com a questão territorial, já em 1932, por meio do decreto n.21.396, apresentara 
uma lei que modificava as relações territoriais entre as entidades de trabalhadores. Com o claro intuito de subordinar os sindicatos a uma lógica de cooperação com os empresários, foram criadas as comissões mistas de conciliação e julgamento, o que significaria que as questões de embate entre o capital e o trabalho seriam agora julgadas tendo o Estado como um árbitro "imparcial".

Muito embora esses sindicatos já demonstrassem uma total submissão aos ditames do governo por, desde o início, aceitarem várias leis limitantes às suas ações, o Estado, como não se sentido ainda totalmente satisfeito, procurava, por meio desse decreto, criar sempre maiores empecilhos a qualquer maior organização dessas entidades. Uma primeira redação do decreto afirmava que:

Nos municípios ou localidades onde não existirem comissões mistas de conciliação, organizadas de acordo com a legislação vigente, os empregados recorrerão às comissões constituídas no município ou localidade mais próxima. (art. $1^{\circ}$, § único, apud Bernardo, 1982, p.91)

Nesse parágrafo, fica evidente que os sindicatos que estivessem em uma localidade na qual a representatividade sindical fosse inexpressiva - e onde, por isso, não existiam comissões de julgamento - poderiam procurar auxílio em cidades vizinhas, onde essas comissões fossem atuantes e os sindicatos mais consolidados. Essa redação propiciaria aos sindicatos menos organizados procurar, minimamente que fosse, o auxílio de entidades congêneres nas cidades próximas e, quem sabe, ter uma maior perspectiva de conquistas nessas comissões tripartites.

Procurando "corrigir" algum erro presente no decreto, no mesmo ano era promulgado o decreto n.22.132, apontando mudanças na forma de organização dessas comissões tripartites, sendo que

Para os municípios onde não existirem associações profissionais de empregados organizados de acordo com a legislação vigente, poderá o Ministério do Trabalho, Indústria e Comércio, ou a autoridade que o representa, organizar também comissões mistas de conciliação. (apud Bernardo, 1982, p.92) 
No entanto, em vez de corrigir ou melhorar, entendemos que as modificações propostas pelo novo decreto limitaram a possibilidade de um sindicato ou grupo de trabalhadores ainda não organizados de aliarem-se a um congênere de uma cidade próxima, pois, na falta de uma comissão mista, o Ministério criaria essa comissão, impedindo uma maior aproximação entre os trabalhadores de cidades vizinhas e a possibilidade de terem um poder de barganha maior.

Para termos um melhor esclarecimento acerca do significado dessas leis no que se refere à questão territorial, faremos um breve histórico, dividindo a década de 1930 em dois curtos períodos.

\section{3 - A ação territorial dos sindicatos oficiais no contexto do corporativismo}

O primeiro período delimitaremos entre novembro de 1930 e junho de 1934. Esse momento foi marcado pelo início das intervenções estatais nas relações entre o capital e o trabalho, com a criação do Ministério do Trabalho, o fim da pluralidade sindical e um ataque sistemático às organizações operárias de cunho revolucionário. Essa fase seria um momento de grande investidura estatal, transformando as entidades sindicais em órgãos privados com função pública, propiciando serviços médico-odontológicos aos seus filiados, advocatícios e de lazer (colônia de férias).

Essa ação do Estado trouxe para dentro do sindicato algumas funções que seriam prerrogativas do governo, como serviços de saúde e a presença de áreas de lazer, promovendo também um arrefecimento das lutas sindicais nessas entidades, que aos poucos se transformariam em órgãos extremamente burocratizados. Por meio do decreto-lei n.19.770, em seu artigo $9^{\circ}$, ficava proibida a pluralidade sindical, delimitando a base territorial dos sindicatos ao município e só em casos excepcionais permitindo a formação de uma entidade intermunicipal. 
Esse decreto determinava que a ação territorial não fosse mais uma deliberação interna do sindicato (comum até meados da década de 1920), mas uma prerrogativa do Estado. Se havia uma clara definição de marcos territoriais para as entidades de trabalhadores, para os empregadores a lei nada dizia no que tange a essa questão, propiciando uma maior liberdade de ação.

Nesse pequeno período de 1930 a 1934, como vimos, as entidades sindicais revolucionárias tiveram que se adequar, e assim continuar existindo dentro da estrutura oficial, ou desapareceram. No caso do PCB e de trotskistas

que se opunham ao governo Vargas tiveram, para sobreviver, que atuar dentro do sindicalismo oficial. [...] Quanto aos anarquistas, caso pedissem a oficialização dos sindicatos, e atuassem dentro dos organismos oficiais, estariam descaracterizando sua própria ideologia anárquica de luta. (Costa, S., 1986, p.31)

Os dois primeiros agrupamentos (comunistas e trotskistas), apesar de serem contrários à ação do Estado sobre o sindicalismo, aos poucos, legalizaram suas entidades. Isso ocorreu porque, caso contrário, correriam o risco de serem marginalizados pela sua própria base, pois os dispositivos principais da nova lei, como a redução da jornada de trabalho para 8 horas diárias, a proteção ao menor no trabalho, a regulamentação de férias, entre outros, só se realizariam em sindicatos legalizados.

Já os sindicatos de orientação anarquista, ao não concordarem com a existência do Estado, e obviamente não se atrelarem ao sindicalismo oficial, perderam aos poucos sua influência sobre os trabalhadores. Costa, S. (1986) afirma que

os anarquistas no início dos anos 1930 tinham ainda maior penetração no seio do movimento operário sindical dos que os comunistas do PCB e os trotskistas. [...] Os anarquistas, já no ano de 1934, passaram a perder quase que totalmente a influência no meio sindical. (Costa, S., 1986, p.28) 
Em julho de 1934, o governo federal promulga o decreto n.24.694. Nesse novo decreto percebe-se a volta da pluralidade sindical com algumas ressalvas, analisadas anteriormente. Esse outro pequeno período destacado por nós iria desta última data até a implantação do Estado Novo (novembro de 1937). Diferente do que ocorria anteriormente, volta-se à pluralidade sindical.

Esse regresso, na prática, foi inconsistente para os trabalhadores. O Estado controlaria suas ações não mais por meio do sindicato único, como em 1931, mas dividiria a categoria que tivesse um sindicato combativo, incentivando a formação de novos agrupamentos sindicais. Logo, ao limitar a ação dos sindicatos à base local, restringiu a sua maneira de agir territorialmente, além do que propiciou uma concorrência entre os sindicatos oficias e os combativos.

Antes mesmo do Estado Novo, o governo coíbe qualquer tentativa de ampliação territorial dos sindicatos, mesmo que agora totalmente controlados. É o que vemos no caso de um sindicato do Rio de Janeiro que pretendia ampliar sua territorialidade para uma cidade vizinha e tem seu pedido negado pelo Ministério do Trabalho

Um sindicato local não pode estender sua jurisdição a outra localidade em que haja sindicato da mesma profissão devidamente reconhecido.

\section{Parecer}

Não há margem legal de amparo à reclamação da Associação de Operários de América Fabril. Trata-se de um sindicato local, com sede no Distrito Federal, que pretende estender o seu raio de atividade a municípios de outros Estados, ou seja, até Pau Grande, Distrito do Município de Magé, Estado do Rio de Janeiro.

Sendo a reclamante um sindicato "local", é fácil de perceber que os dispositivos estatutários que lhe permitem o estabelecimento de comissões nas diversas seções da Companhia América Fabril devem ser entendidos dentro da base territorial traçadas ao sindicato. De qualquer modo não nos parece lícito a esse sindicato estender sua atividade a determinados distritos municipais de outros estados. $\mathrm{O} 2^{\circ}$ artigo do decreto n.24.694 de 1934 a isto se oporia. (Revista do Trabalho, 1937) 
Esse caso demonstra a atuação do Estado na ação territorial dos sindicatos, proibindo uma ampliação da área de influência. Ao procurar ampliar sua base territorial, o sindicato esbarrou numa legislação limitante. Nesse caso, tinha-se o agravante de que o distrito de Magé localizava-se em outro estado.

$\mathrm{Na}$ verdade, a negativa do parecerista do Ministério do Trabalho deixa clara a intenção do governo em dificultar ao máximo a ampliação da territorialidade de um sindicato. Isso porque, analisando a história da empresa, ${ }^{15}$ percebemos que tinha sua sede na cidade de Magé (distrito de Pau Grande) desde 1875, sendo que em 1889, junto a ela, é fundada a Fábrica Rio Grande, para a fabricação de tecidos de meia.

Em 1891, a empresa se expande, iniciando as atividades na cidade do Rio de Janeiro, com a criação da Fábrica Cruzeiro, no bairro do Andaraí. A partir daí seguiram algumas incorporações de indústrias da cidade do Rio de Janeiro, como a Fábrica Bonfim (1920 - situada no bairro do Caju), a Fábrica Mavilis (1911 - situada no bairro do Caju) e a Fábrica Carioca (1920 - situada no bairro da Gávea).

Percebemos então que a Associação de Operários, ao solicitar a ampliação de sua base territorial, buscava seguir a própria territorialidade da empresa. Ao ser negado o pedido, o parecerista propicia que no mesmo grupo empresarial existissem vários sindicatos de trabalhadores. Ou seja, num movimento de greve, algumas fábricas poderiam parar e outras trabalhar normalmente.

$\mathrm{O}$ enquadramento dos sindicatos possibilitou mais do que um simples controle. Ele promoveu uma maior fragmentação da classe operária, dificultou a organização territorial dessas entidades e tornou-as porta-vozes da política econômica e social desse Estado.

Enquanto no Estado liberal alguns sindicatos unificavam-se com suas congêneres mais organizadas, como forma de fortalecerem seus laços na luta contra o capital, a partir de 1931 essas ações seriam desencorajadas, estimulando-se, com a "lei de sindicali-

15 Mais informações sobre a empresa, ver: <http://www.rio.rj.gov.br/arquivo/ pdf/guia/coleção_particular_america_fabril.pdf>. Acesso em: 1/3/2011. 
zação", o surgimento de sindicatos sem qualquer expressividade, compostos por uma burocracia desinteressada pelas demandas de seus associados.

Antes mesmo da instalação do Estado Novo, os sindicatos, em sua expressiva maioria, já estavam subordinados à nova legislação e, assim, defendiam abertamente as orientações e exigências que o Estado a eles tinha determinado. Em 1937, num encontro patrocinado por sindicatos reconhecidos pelo Estado, a questão territorial é novamente levantada. Mas não se tratava de questionar os encaminhamentos que o governo vinha fazendo há sete anos. Pelo contrário, o encontro teve vários momentos de agradecimento, demonstrando a afinidade entre os sindicatos e o Estado:

Em falando ao proletariado paulista, Antonio Oliveira Aguiar, em nome do Presidente da União Geral dos Sindicatos de Empregados do Distrito Federal, na solenidade de entrega da carta de reconhecimento da União Geral dos Sindicatos de Trabalhadores de São Paulo, realizada a 14 de fevereiro de 1937, afirmava que com a lei de sindicalização "os tempos sinistros perderam-se já nos longes do pretérito". A revolução nacional de 1930 conseguiu melhorar a sorte do proletariado, fazendo-lhe justiça. Ninguém poderá negar, sem cometer um grave erro de observação, que o proletariado atingiu uma situação de desafogo, amparado em leis específicas de proteção, anteriormente existentes. (Boletim do Ministério do Trabalho, Indústria e Comércio, 1937, p.111-119)

Num dado momento, o sindicalista demonstra a submissão dessas entidades às propostas oficiais. Muda-se o comportamento dos sindicatos com relação ao Estado. A partir de agora, ele é visto como um incentivador de certa consciência de classe:

Favorecidos por este amparo simultâneo, o do governo da República e do seu Ministro do Trabalho, o proletariado brasileiro de Norte a Sul do país vem progredindo, vai se educando nos ditames 
da associação, vai alterando sua mentalidade sindical, vai adquirindo, pouco a pouco, a consciência de classe. (Boletim do Ministério do Trabalho, Indústria e Comércio, 1937, p.111-119)

E, no final do encontro, o mesmo sindicalista agradece ao Estado por acabar com as diferenças estaduais e regionais que os trabalhadores tinham antes da criação do Ministério do Trabalho. Desde a implementação dessas mudanças, segundo ele, o proletariado brasileiro tornou-se um só, e unido trabalhando para a nação:

Unidos seremos tudo, a força invencível. Unidos do Norte ao Sul. Unidos brasileiramente. Unidos proletariamente. Não há proletário paulista, nem carioca, nem fluminense, mineiro, baiano, gaúcho ou paraense. Deve haver apenas proletário do Brasil ou simplesmente proletário. Para essa união que desejamos indissolúvel, os marcos da convenção geográfica não devem prevalecer. Essa união necessária deve sobrepor-se aos regionalismos estéreis que só beneficiam aos algozes da nossa classe. (Boletim do Ministério do Trabalho, Indústria e Comércio, 1937, p.111-119)

Interessante observar que a sintonia entre o movimento sindical e o Estado já se apresentava quase que total. Ao defenderem o "fim" das fronteiras internas, demonstrando que o proletariado era, a partir daquele momento, único, sem as diferenças regionais, antecipava, em poucos meses, a famosa queima das bandeiras estaduais, que sacramentava de vez a política antifederalista do regime.

Sobre esse último evento, Martin (1993) comenta

Logo após a promulgação da nova Constituição de 1937 [outorgada em 10 de novembro desse ano], uma solenidade desenrolada na Esplanada do Russel, no Rio de Janeiro, e presenciada pelo próprio Getúlio Vargas, não deixa dúvidas sobre o caráter fortemente antifederalista do regime que se instaurava. As bandeiras estaduais foram queimadas, suprimiram-se os hinos estaduais, assim como os escudos dos Estados e até dos municípios, e proclamou-se a intenção 
de o Estado federal colocar-se "à frente das soluções", organizando, ele próprio, planos de desenvolvimento regional para o Nordeste, a Amazônia e o Centro-Oeste. (Martin, 1993, p.179-180)

A instituição do Estado Novo, ${ }^{16}$ que não temos a intenção de discutir neste trabalho, trouxe outras características com a nova legislação sindical (por exemplo, o decreto-lei n.1402, de 1939, exigia novamente a unicidade sindical), mas as bases para a existência de um Estado corporativo no Brasil há muito tempo já existiam.

O processo de intervenção estatal nos sindicatos cumpria o seu principal objetivo: transformar o sindicato em órgãos de função púbica, defensores do regime instaurado. Se no Estado liberal vários sindicatos procuravam se aliar aos seus congêneres para a ampliação de um movimento grevista, questionando tanto o patronato quanto o Estado, agora as entidades reconhecidas agradeciam ao Estado pelas "benesses" que foram por ele outorgadas.

Frases como "vai se educando nos ditames da associação, vai alterando sua mentalidade sindical" ou "deve-se sobrepor aos regionalismos estéreis", que pareceriam ser tiradas de algum artigo de Oliveira Vianna, um dos mentores desse Estado corporativo, agora já faziam parte do discurso dos sindicatos. Não se tratava mais de combater alguma classe em especial, muito menos o Estado. A função dos sindicatos agora era uma só: servir de instrumento para a manutenção de um Estado corporativo no país.

Para nós, essa ação estatal que se inicia no final de 1930, com a criação do Ministério do Trabalho, impôs ao operariado uma fragmentação territorial, já que circunscreveu as ações desse movimento à rígida divisão administrativa municipal, dinâmica essa que não seria necessariamente aquela seguida pelo capital. Nesse sentido, as ações do Estado promoveram a pulverização das lutas dos trabalhadores e transformaram os sindicatos em organismos sem qualquer mobilidade. Como afirma Moreira (1985),

16 É importante frisar que no ano de 1939 é instituído o decreto-lei n.1402, que revogava o anterior, o decreto 24.694, de julho de 1934. 
Dissolvendo a regra básica anarcossindicalista de deixar a forma de organização sindical entregue às determinações das próprias necessidades da movimentação operária, o Estado cria o sindicato único, padronizado, sendo características dessa padronização o particularismo, o paralelismo e o verticalismo. [...] O critério da correlação categoria-território destina-se à desagregação da unidade das ações do operariado sobre a base da reiteração da divisão técnica do trabalho capitalista, submetendo-as, na segregação categorialterritorial, à tutela ministerial. (Moreira, 1985, p.108)

Ao delimitar a área de atuação do sindicato, quase sempre circunscrita à divisão administrativa municipal, o Estado conseguiu diminuir as relações intermunicipais e inter-regionais dessas entidades, controlando os sindicatos mais fortes e enfraquecendo as categorias que estavam em fase de amadurecimento e necessitavam unirem-se aos seus companheiros de luta.

Mais ainda, trouxe para o interior da classe operária uma maior fragmentação territorial e de categorias, o que em médio prazo dificultava qualquer possibilidade de formação de amplas uniões, seja em nível nacional (como a formação de uma central), ou seja de diversas categorias em busca de um resultado comum (como a que ocorreu na Greve Geral de 1917). ${ }^{17}$

Essa ação estatal, ao interferir na forma de organização dos sindicatos (interna ou externa), contribuiu para o surgimento de sindicatos enfraquecidos, totalmente dependentes e de limitada ação territorial.

17 Segundo Simão (1966), só após a Segunda Guerra Mundial os sindicatos conseguiram ter uma pequena ampliação da sua base territorial, como a intermunicipal. Até o conflito mundial, "Mesmo os sindicatos ficam enquistados em suas circunscrições municipais, não podendo se articular neste ou em qualquer outro âmbito, mas apenas se representarem em suas respectivas federações estaduais" (Simão, 1966, p.187). 


\section{CONSIDERAÇÕES FINAIS}

Esta pesquisa partiu do pressuposto de que a territorialidade, entendida como estratégia dos sindicatos na luta por melhores condições de existência da classe trabalhadora, constitui-se em importante elemento de embate entre capital e trabalho, tendo a mediação política do Estado.

O estudo das territorialidades sindicais na prevalência de um Estado liberal ou de tipo corporativo demonstrou-nos as diferentes formas de tratamento do poder público com relação às entidades de trabalhadores.

Essa política estatal diferenciada, como vimos, baseada nos pressupostos ideológicos defendidos pelas elites no poder, junto a uma específica forma de atuar dos sindicatos-revolucionários, determinou diversas estratégias de organização dessas agremiações.

No Brasil, a passagem do Estado liberal para o Estado corporativo a partir da chamada Revolução de 30, sob o governo de Getúlio Vargas, resulta na imposição de territorialidade diferenciada da vigente até então, promovendo um enfraquecimento na organização externa dos sindicatos.

Muito embora as ações dos sindicatos nesse período tenham sido amplamente estudadas por outras ciências humanas, pouco foi agregado ao conhecimento científico sobre as práticas territoriais do movimento sindical. Ao aceitarmos o desafio de analisar os sindicatos levando em consideração essas ações territoriais, buscávamos 
compreender de que forma elas ocorriam e como o Estado interferia nessa dinâmica.

Para nós, não se tratava de utilizar a Geografia, enquanto ciência que analisa as ações no espaço e no território, como um simples acréscimo aos vários trabalhos existentes e amplamente divulgados. Mais do que a preocupação em colocar a Geografia nesse debate, o importante para a nossa pesquisa era compreender como essa relação entre o Estado e os sindicatos ocorria. Ou seja, quais mecanismos de análise a ciência geográfica poderia fornecer para um melhor entendimento das ações sindicais e do papel do Estado perante elas.

A partir dessa compreensão, percebemos também que não se tratava de apontar essas territorialidades apenas, mas demonstrá-las na prática cotidiana dos sindicatos, como um elemento de grande importância para uma melhor consecução de suas lutas. Nesse sentido, não vemos a territorialidade apenas como uma expressão geográfica do movimento sindical, mas principalmente como uma estratégia desse movimento, seja para superar as enormes dificuldades que essas entidades percebiam, seja também como um mecanismo de ação contra o capital e o Estado.

Enquanto estratégia, as várias territorialidades se mostraram úteis aos trabalhadores, uma vez que possibilitavam uma maior aproximação entre as entidades e, principalmente, funcionavam como um meio de se conquistar melhores condições de trabalho, de salário, de vida etc.

Por outro lado, a ação do Estado corporativo tal como se constitui no Brasil a partir da Revolução de 30 estabelece-se e impõe-se por ações políticas, pela legislação e por repressão aos sindicatos mais combativos, diretrizes obrigatórias que desmantelam a possibilidade das ações sindicais nas bases territoriais anteriormente determinadas.

Os trabalhadores puderam, em momentos determinados, superar a extensão continental que o país possuía, num período de limitadas possibilidades de comunicação em grandes distâncias, que significavam um entrave à união da classe trabalhadora. Inúmeras formas de relacionamento foram aplicadas a fim de que as entidades conseguissem um mínimo que fosse de integração. 
Foram constantes nos jornais operários casos de entidades de áreas afastadas do país buscando a solidariedade das agremiações dos grandes centros. As viagens promovidas pelos sindicatos mais organizados na tarefa de incentivar a criação de entidades nas regiões Nordeste e Norte do país demonstraram que essas excursões sindicais eram tão prementes quanto aquelas ligadas exclusivamente à subsistência das entidades.

A questão territorial esteve sempre colocada para a organização sindical, na criação de sucursais nas áreas suburbanas das grandes cidades; na formação de uma rede estadual de filiais, em que uma entidade de uma cidade central ampliava a sua área de atuação; no processo de construção de um sindicato nacional e na articulação de entidades representativas dos trabalhadores quando da necessidade de ampliação de um movimento de greve, as chamadas "greves de solidariedade".

Independentemente dos resultados conquistados nas lutas cotidianas, já que derrotas e vitórias são comuns aos que buscam melhorias, a investigação demonstrou que a ação territorial dos sindicatos foi um fator importante de se considerar nesse processo de construção de um sindicalismo mais combativo. Procuramos demonstrar que essas lutas se desenvolviam em espaços específicos, nos quais essa rede territorial de entidades era um mecanismo de enfrentamento. Isso porque a ação direta, o federalismo e a autogestão, as principais bandeiras do movimento sindical mais combativo, tinham o território como um importante substrato material.

Ao longo da pesquisa fomos compreendendo que as lutas sociais se desenvolviam em um dado espaço, um território determinado, e assim ficava mais clara a presença de uma articulação dessas entidades como forma de romper o isolamento inerte de várias entidades sindicais, próprio de uma classe social em formação.

A formação de uma ação estatal corporativista, que tinha como um dos principais objetivos o monitoramento das atividades sindicais, possibilitou um controle desse Estado corporativo sobre as territorialidades das entidades de classe, transformando a forma de elas se organizarem. 
O controle sindical corporativista não se fez aleatoriamente ou como consequência secundária dos propósitos de integração territorial do Brasil. Buscou-se com isso, também, a formação daquilo que seria, na concepção corporativista, uma nação forte, com boas condições econômicas, capaz de resolver suas dificuldades e sair da condição de país agrário.

Uma das preocupações desse Estado era a de dificultar quaisquer relações entre as entidades de classe dos trabalhadores, principalmente aquelas que se referissem à ação territorial, incentivando a divisão do sindicato até o máximo do atomismo e, concomitantemente a isso, impondo a elas uma diminuta base territorial.

Colocado isso, não nos furtamos em afirmar: a intervenção do Estado nos sindicatos significou também um controle sobre suas ações territoriais. Sindicatos atomizados com pequena base territorial. Eis o lema do Estado corporativo no Brasil. São explícitas as intenções desse Estado nas palavras de um de seus principais ideólogos.

Uma boa parte do sindicalismo atual, surgido ou tendo seu representante transformado a partir de 1931, com a lei de sindicalização, pouco sabe das primeiras lutas em busca de melhores condições de vida e afirmam que a origem de sua entidade está ligada às mudanças ocorridas com a intervenção estatal nos sindicatos. Um desses exemplos é o Sindicato dos Metalúrgicos de São Paulo, resumidamente discutido no Capítulo 4.

A lógica que predominou após a intervenção do Estado nos sindicatos parece, pelo menos em parte, ter seu resultado satisfatório: apagar da memória das classes trabalhadoras as diversas lutas e os diversos sindicatos combativos existentes antes e depois de 1930.

Com isso, apagaram-se também da memória sindical as diversas territorialidades desse período. E hoje a base territorial de um sindicato quase nunca é questionada, como se fosse um dado natural, assim como também se aceita sem maiores questionamentos a origem de alguns sindicatos, tendo-se como processo formador, único e exclusivamente, a intervenção estatal desencadeada com a Revolução de 1930. 
Para nós, esta obra pode, ainda que implicitamente, apontar como as mudanças no sindicalismo brasileiro na década de 1930 podem ter algumas ressonâncias na atualidade, sendo comum a existência de vários sindicatos diminutos ligados a uma pequena base territorial. Mais do que isso, procuramos demonstrar que a questão da unicidade e da pluralidade sindical, ainda hoje na ordem do dia nos projetos de reforma sindical, são inseparáveis da questão territorial e, portanto, de uma análise geográfica sobre os sindicalismo.

Ressalte-se que a territorialidade definida nos anos 1930 permanece até nossos dias em grande parte, ainda que na história recente do Brasil tenhamos tido alterações de regimes democráticos e mais um período ditatorial. ${ }^{1}$

A Geografia, enquanto ciência que analisa o território, pode fornecer subsídios para essa compreensão, mas também instrumentos para a luta de diversas categorias de trabalhadores, quer estejam organizados nos movimentos dos sem-terra, dos sem-teto, ou mesmo nos sindicatos.

A análise da territorialidade sindical mostrou-nos a necessidade de se continuar essa pesquisa estudando outros períodos de nossa história, a fim de entender melhor os mecanismos de controle territorial que o Estado Novo trouxe para os sindicatos oficias, não se furtando em analisar o significada da implantação da CLT no que tange às ações territoriais.

Para isso, cabe à Geografia e a seus geógrafos a realização dessa tarefa, demonstrando o potencial que essa ciência pode fornecer para uma melhor compreensão das relações entre o capital, o trabalho e o Estado.

1 Embora a Constituição de 1988 , no seu artigo $8^{\circ}$, afirme que a base territorial dos sindicatos possa ser determinada pelos próprios interessados (trabalhadores ou empresários), são poucos, ainda, os sindicatos de trabalhadores que possuem uma base territorial superior à área intermunicipal. Para uma análise da Constituição de 1988, acessar o site <http://www.planalto.gov.br/ccivil_03/ constituicao/constitui\%C3\%A7ao.htm>. Acesso em: 23/6/2011. 


\section{REFERÊNCIAS BIBLIOGRÁFICAS}

ABENDROTH, Wolfgang. A História social do movimento trabalhista europeu. Rio de Janeiro: Paz e Terra, 1977.

ANDRADE, Manuel Correia de. Estado, capital e industrialização do nordeste. São Paulo: Zahar Editora, 1981.

. As raízes do separatismo no Brasil. São Paulo: Edusp, 1998. . A federação brasileira: uma análise geopolítica e geossocial. São Paulo: Editora Contexto, 2003.

ANDREUCCI, Franco. A difusão e vulgarização do marxismo. In: HOBSBAWM, Eric. História do marxismo: o marxismo na época da segunda internacional (primeira parte). v.II. Rio de Janeiro: Paz e Terra, 1982, p.15-74.

ANTUNES, Ricardo C. Classe operária, sindicatos e partido no Brasil: um estudo sobre a consciência de classe: da revolução de 30 até a aliança nacional libertadora. São Paulo: Cortez Editora, 1982; 1988.

ARAUJO, Ângela. Construindo o consentimento: corporativismo e trabalhadores no Brasil dos anos 30.1994. 328 f. Tese (Doutorado em Ciências Sociais). Universidade de Campinas, Campinas, 1994.

. Estado e trabalhadores - a montagem da estrutura sindical corporativista no Brasil. In: ARAUJO, Ângela (Org.). Do corporativismo ao neoliberalismo - estado e trabalhadores no Brasil e na Inglaterra. São Paulo: Boitempo, 2002, p.29-57. 
AURELIANO, Liana Maria. No limiar da industrialização. São Paulo: Brasiliense, 1981.

BANDEIRA, Pedro S. A produção gaúcha na economia nacional: resposta a uma crítica. Ensaios FEE, Porto Alegre, 1984.

BANDEIRA, Moniz. O ano vermelho: a Revolução Russa e seus reflexos no Brasil. Rio de Janeiro: Civilização Brasileira, 1967.

BATALHA, Claudio (Org.). Dicionário do movimento operário. Rio de Janeiro do século XX aos anos 1920, militantes e organizações. São Paulo: Perseu Abramo, 2009.

- O movimento operário na primeira república. Rio de Janeiro: Jorge Zahar, 2000.

BEIGUELMAN, Paula. Os companheiros de São Paulo. São Paulo: Edições Símbolo, 1968.

BERNARDO, Antonio Carlos. Tutela e autonomia sindical: Brasil 1930-1945. São Paulo: T. A. Queiroz, 1982.

BIHR, Alan. Da grande noite à alternativa: O movimento operário europeu em crise. São Paulo: Boitempo, 1998.

BONAVIDES, Paulo. Do estado liberal ao estado social. Rio de Janeiro: Forense, 1980.

CANDIOTTO, Luciano Zanetti Pessoa. Experiências geográficas em torno de uma abordagem territorial. In: SAQUET, Marcos Aurélio et al. (Org.). Territórios e territorialidades - teorias, processos e conflitos. São Paulo: Expressão Popular, 2009, p.315-340.

CANÊDO, Letícia B. A classe operária vai ao sindicato. São Paulo: Contexto, 1988; 1991.

CANO, Wilson. Raízes da concentração industrial em São Paulo. São Paulo: Difel, 1976.

CARNOY, Martin. Estado e teoria política. Campinas: Papirus, 1994.

CARONE, Edgar. Movimento operário no Brasil. 3v. São Paulo: Difel,1984.

. A primeira república 1889-1930: texto e contexto. Rio de Janeiro: Difel, 1976.

CARVALHAL, Marcelo Dornellis. A dimensão territorializante da qualificação profissional em São Paulo: A ação dos sindicatos. 2004. 344 f. Tese (Doutorado em Geografia) - Faculdade de 
Ciências Tecnológicas, Universidade Estadual paulista, Presidente Prudente, 2004.

COELHO, João Gilberto Lucas. Breves anotações sobre a Constituição de 1934. Correio Brasiliense, Brasília, n.8560, p.3, 13 set. 1986. Disponível em: <http://www2.senado.gov.br/bdsf/item/ id/117544>. Acesso em: 10/8/2010.

COLLE, G.D.H. Historia del pensamiento socialista. México: Fondo de Cultura Econômica, 1986.

CONGRESSO OPERÁRIO DE 1912. Estudos Sociais, v.IV, n.17, junho 1963.

COSTA, Emilia Viotti da. Da Monarquia à República: momentos decisivos. São Paulo: Editora Unesp, 1998.

COSTA, Rogério Haesbaert. O mito da desterritorialização: do fim dos territórios à multiterritorialidade. Rio de Janeiro: Bertrand Brasil, 2004.

. Dilemas de conceitos: espaço-território e contenção territorial. In: In: SAQUET, Marcos Aurélio et al. (Org.). Territórios e territorialidades - teorias, processos e conflitos. São Paulo: Expressão Popular, 2009, p.95-120.

COSTA, Sérgio Amad. Estado e controle sindical no Brasil. São Paulo: T. A. Queiroz, 1986.

COSTA, Wanderley M. O estado e as políticas territoriais no Brasil. São Paulo: Contexto/ Edusp, 1988.

- Geografia política e geopolitica - Discursos sobre o território e o poder. São Paulo: Hucitec/ Edusp, 1992.

DEAN, Warren. A industrialização de São Paulo. São Paulo: Editora Difel, 1971.

. A industrialização durante a República Velha. In: História geral da civilização brasileira, tomo III, o Brasil republicano. Estrutura de Poder e Economia (1889-1930). v.I. São Paulo: Difel,1975, p.251-283.

DIAS, Everardo. História das lutas sociais no Brasil. São Paulo: Alfa-ômega, 1977.

DULLES, John F. Anarquistas e comunistas no Brasil. Rio de Janeiro: Nova Fronteira, 1977. 
DURKHEIM, Émile. Lições de sociologia. São Paulo: Martins Fontes, 2002.

FAUSTO, Boris. História do Brasil. São Paulo: Edusp, 2009.

. O pensamento nacionalista autoritário (1920-1940). Rio de Janeiro: Jorge Zahar, 2001.

. A revolução de 1930 (História e Historiografia). 16.ed. São Paulo: Editora Brasiliense, 1997.

Trabalho urbano e conflito social (1890-1920). São Paulo: Difel, 1976.

FERNANDES, Bernardo Mançano. Sobre tipologias de territórios. In: SAQUET, Marcos Aurélio et al. (Org.). Territórios e territorialidades - teorias, processos e conflitos. São Paulo: Expressão Popular, 2009, p.197-215.

FERRERIA, Maria N. A imprensa operária no Brasil (1880-1920). São Paulo: Vozes, 1978.

FOUCAULT, Michel. O nascimento da biopolítica. São Paulo: Martins Fontes, 2008.

FRIEDMAN, Milton. Capitalismo e liberdade. São Paulo: Nova Cultural, 1985.

FUNDAÇÃO IBGE. Censo industrial do Brasil - 1907 - o Brasil Suas Riquezas Naturaes; Suas Industrias. Série Histórica. Rio de Janeiro: FIBGE, 1986.

GEIGER, Pedro P. Evolução da rede urbana brasileira. Rio de Janeiro: CBPE, 1963.

HARDMAN, Francisco Foot et al. História da indústria e do trabalho no Brasil. São Paulo: Global Editora, 1982.

HEGEDUS, András. A construção do socialismo na Rússia: o papel dos sindicatos, a questão camponesa, a nova política econômica. In: HOBSBAWM, Eric. História do marxismo: o marxismo na época da terceira internacional: A URSS da construção do socialismo ao stalinismo. O marxismo na época da terceira internacional. v.VII. Rio de Janeiro: Editora Paz e Terra, 1986, p.87-123.

HEILBRONER, Robert L. A história do pensamento econômico. São Paulo: Nova Cultural, 1996. 
IANNI, Octavio. Estado e planejamento econômico no Brasil (19301970). São Paulo: Civilização Brasileira, 1979.

IGLESIAS, Francisco. Industrialização brasileira. São Paulo: Editora Brasiliense, 1958.

I.S.V. A concepção marxista de sindicatos - o programa de ação da internacional sindical vermelha. São Paulo: Outubro, 1994.

LAMOUNIER, Bolívar. Formação de um pensamento político autoritário na primeira república. Uma Interpretação. In: FAUSTO, Boris (org). História geral da civilização brasileira, Tomo III. O Brasil Republicano. VII. Rio de Janeiro: Difel, 1985, p.310-370.

LEME, Dulce Maria Pompêo de Camargo. Trabalhadores ferroviários em greve. Campinas: Editora da Unicamp, 1986.

LÊNIN, Wladimir. Sobre os sindicatos. São Paulo: Editora Polis, 1979.

LEVAL, Gastón. Bakunin, fundador do sindicalismo-revolucionário./ A dupla greve de Genebra. São Paulo: Imaginário/Faísca Publicações Libertárias, 2007.

LIMA, João Heraldo. Café e indústria em Minas Gerais. Petrópolis: Vozes, 1981.

LOPREATO, Christina R. O espírito da revolta: a greve geral anarquista de 1917. São Paulo: Annablume, 2000.

LOVE, Joseph et al. O poder dos estados - análise regional. In: FAUSTO, Boris (Org.). História geral da civilização brasileira, tomo III. - O Brasil republicano. $1^{\circ}$ Volume (estrutura de poder e economia - 1889-1930). São Paulo: Difel, 1982, p.70-95.

MARAM, Leslie Sheldon. Anarquistas, imigrantes e o movimento operário 1890/1920. São Paulo: Paz e Terra, 1975.

MARTIN, André Roberto. As fronteiras internas e a questão regional. 1993. 240f. Tese (Doutorado em Geografia) - Departamento de Geografia, Universidade de São Paulo, São Paulo, 1995.

MARTINS, José de Souza. O cativeiro da terra. São Paulo: Brasiliense, 1986.

MELLO, João Manuel C. O capitalismo tardio. São Paulo: Brasiliense, 1982, 182p. 
MELLO, Leonel Itaussu. John Locke e o individualismo liberal. In: WEFFORT, Francisco (Org.). Os clássicos da política - Maquiavel, Hobbes, Locke, Montesquieu, Rousseau, "O federalista". São Paulo: Ática, 2004, p.79-110.

MENDONÇA, Sonia Regina de. Estado e sociedade: a consolidação da república oligárquica. In: LINHARES, Maria Yeda (Org.). História Geral do Brasil. Rio de Janeiro: Campus, 2000, p.229-242. MIYAMOTO, Shiguenoli. O pensamento geopolítico brasileiro 19201980. 1981. 287f. Dissertação (Mestrado em Ciência Política) Departamento de Ciência Política, Universidade de São Paulo, São Paulo, 1981.

MORAES, Antonio Carlos Robert. Ideologias geográficas - espaço, cultura e política no Brasil. São Paulo: Hucitec/Annablume, 1988. . Capitalismo, geografia e meio ambiente. $202 \mathrm{f}$. Tese (Livre Docência). Departamento de Geografia, Universidade de São Paulo, São Paulo, 2000.

. Geografia: pequena história crítica. São Paulo: Hucitec, 1987. . Território e história no Brasil. São Paulo: Annablume/Editora Hucitec, 2002. . Ratzel. São Paulo: Ática, 1990.

. O que é território? Revista Orientação, edição suplementar, Departamento de Geografia, out.1984, p.91.

MORAES FILHO, Evaristo de. O problema do sindicato único no Brasil - seus fundamentos sociológicos. São Paulo: Alfa-Ômega, 1978.

MOREIRA, Ruy. O movimento operário e a questão cidade-campo no Brasil: Estudo sobre Sociedade e Espaço. Rio de Janeiro: Vozes, 1985.

MUNATA, Kazumi. A legislação trabalhista no Brasil. São Paulo: Brasiliense, 1984.

OLIVEIRA, Maria Teresa Ribeiro de. Indústria têxtil mineira do século XX. In: SILVA, Sérgio et al. História econômica da primeira república. São Paulo: Contexto/ Hucitec, 1996, p.36-90.

PENHA, Eli Alves. A criação do IBGE no contexto da centralização política do Estado Novo. Rio de Janeiro: FIBGE, 1993. 
PEREIRA, Astrojildo. Formação do PCB: 1922-1928. Lisboa: SARL, 1976.

PINHEIRO, Paulo Sérgio et al. A classe operária no Brasil. O movimento operário. v.I. São Paulo: Editora Alfa-ômega, 1979.

POLANYI, Karl. A grande transformação: as origens de nossa época. Rio de Janeiro: Campus, 1980.

RAFFESTIN, Claude. Por uma geografia do poder. São Paulo: Ática, 1993

REALE, Miguel. O Estado moderno (liberalismo-fascismo-integralismo). Rio de Janeiro: J. Olympio, 1935.

RESENDE, Maria Efigênia de. O processo político na primeira república e o liberalismo oligárquico. In: FERREIRA, Jorge (Org.). O Brasil republicano I: o tempo do liberalismo excludente. v.I. Rio de Janeiro: Civilização Brasileira, 2006, p.90-115.

RIBAS DA COSTA, Milene. A implosão da ordem: a crise final do império e o movimento republicano paulista. 2006. 118f. Dissertação (Mestrado em Ciência Política), Departamento de Ciência Política, Universidade de São Paulo, São Paulo, 2006.

RODRIGUES, Edgar. Alvorada operária. Rio de Janeiro: Mundo Livre, 1979.

. Novos rumos (história do movimento operário e das lutas sociais no Brasil 1922-1946). Rio de Janeiro: Mundo Livre, 1978.

RODRIGUES, Leôncio Martins. Trabalhadores, sindicatos e industrialização. São Paulo: Editora Brasiliense, 1974.

SALLES, Iza. Um cadáver ao sol: A história do operário brasileiro que desafiou Moscou e o PCB. São Paulo: Ediouro, 2005.

SAMIS, Alexandre. Introdução. In: LEVAL, Gastón. Bakunin, fundador do sindicalismo revolucionário/ A dupla greve de Genebra. São Paulo: Editora Faísca/ Imaginário, 2007 p.7-18.

SAMIS, Alexandre. Pavilhão negro sobre a pátria oliva: sindicalismo e anarquismo no Brasil. In: História do movimento operário revolucionário. São Paulo: Editora Imaginário, 2004, p.125-190.

SANTOS, Roberto. História econômica da Amazônia (1880-1920). São Paulo: T. A. Queiroz, 1980. 
SANTOS, Wanderley Guilherme dos. Ordem burguesa e liberalismo político. São Paulo: Duas Cidades, 1978.

SÉRIE ESTATÍSTICAS RETROSPECTIVAS. O Brasil, suas riquezas naturais, suas indústrias. Tomo 3 - Indústria de transportes, indústria fabril. Rio de Janeiro: FIBGE, 1986.

SILVA, Sergio. Expansão cafeeira e origens da indústria no Brasil. São Paulo: Alfa-Ômega, 1976.

SILVEIRA, Rosa Maria G. Republicanismo e federalismo, 18891902: um estudo da implantação da república brasileira. Brasília: Senado Federal, 1978.

SIMÃO, Aziz. Sindicato e estado. São Paulo: Dominus, 1966.

SMITH, Adam. The Invisible Hand. London: Penguin, 2008.

SINGER, Paul. Desenvolvimento econômico e evolução urbana: análise da evolução econômica de São Paulo, Blumenau, Porto Alegre, Belo Horizonte e Recife. São Paulo: Companhia Editora Nacional, 1974.

STEIN, Stanley. The Brazilian Cotton Manufacture: Textile Enterprise in an Underdeveloped Area, 1850-1950. Cambridge, Mass.: Harvard University, 1957.

SOUZA, Marcelo Lopes de. O território: sobre espaço e poder, autonomia e desenvolvimento. In: CASTRO, I.; GOMES, P. (Org.). Geografia: conceitos e temas. Rio de Janeiro: Bertrand Brasil, 1995, p.77-116.

STEPAN, Alfred. Estado, corporativismo e autoritarismo. Rio de Janeiro: Editora Paz e Terra, 1980.

STEWART, Donald. Que é o liberalismo? Rio de Janeiro: Instituto Liberal, 1988.

SUZIGAN, Wilson. Indústria brasileira: origem e desenvolvimento. São Paulo: Editora Brasiliense, 1986.

THOMAZ JR, Antonio. Por trás dos canaviais: Os nós da cana. São Paulo: Annablume/Fapesp,1996.

TOLEDO, Edilene. Travessias revolucionárias: ideias e militantes sindicalistas em São Paulo e na Itália (1890-1945). Campinas: Editora da Unicamp, 2004. 
TOYOSHIMA, Silvia H. Evolução de uma economia periférica: o caso de Minas Gerais. 1986.144f. Dissertação (Mestrado em Economia) - Faculdade de Economia e Administração, Universidade de São Paulo, São Paulo, 1986.

TRONCA, Ítalo. Revolução de 1930: a dominação oculta. São Paulo: Brasiliense, 1982.

TROYANO, Annez Andraus. Estado e sindicalismo. São Paulo: Símbolo, 1978.

VARGAS, João Tristan. O trabalho na ordem liberal: o movimento operário e a construção do Estado na primeira república. Campinas: CMU, 2004.

VASCO, Neno. Concepção anarquista de sindicalismo. Porto: Afrontamento, 1984.

VERSIANI, Maria Tereza R. O. A industrialização brasileira antes de 1930: uma contribuição, Estudos Econômicos, v.5, n.1, jan.-abr. 1975, p.37-63.

VIANNA, Luiz Werneck. Liberalismo e sindicato no Brasil. Rio de Janeiro: Editora Paz e Terra, 1976.

VIANNA, F. J. Oliveira. Direito do trabalho e democracia social: o problema da incorporação do trabalhador no Estado. Rio de Janeiro: José Olympio, 1951.

. Problemas do direito sindical. Rio de Janeiro: Max Limonad, 1943.

VIEIRA, Evaldo. Autoritarismo e corporativismo no Brasil. São Paulo: Cortez, 1981.

VIZENTINI, Paulo G. Liberais e a crise da república velha. São Paulo: Brasiliense, 1983.

VON MISSES, Ludwig. Liberalismo: segundo a tradição clássica. Rio de Janeiro: José Olympio, 1987.

WEFFORT, Francisco (Org.). Os clássicos da política: Maquiavel, Hobbes, Locke, Mostesquieu, Rousseau, "O federalista”. v.I. São Paulo: Ática, 2004.

WILLIAMSON, Peter. Corporatism in Perspective: An Introductory Guide to Corporatist Theory. Great Britain: Sage, 1990. 
ZAIDAN, Michel. O PCB e a internacional comunista - 1922-1929. São Paulo: Vértice, 1988.

\section{Fontes}

\section{Imprensa Operária}

O Proletário, Alagoas, 1902.

A Voz do Trabalhador, Rio de Janeiro, 1908-1915.

A Voz Operária, Pernambuco, 1916-1917.

O Caduceu, Alagoas, 1918.

A Voz do Trabalhador, São Paulo, 1919.

A Voz Operária, São Paulo, 1919.

A Revolta, Pará, 1919.

A Vanguarda, Pernambuco, 1919.

A Aurora, Rio de Janeiro, 1919.

Boletim da Comissão Executiva do $3^{\circ}$ Congresso Operário, Rio de Janeiro, 1920.

A União, Rio Grande do Sul, 1920.

A Voz do Trabalhador, Pará, 1920.

O Escravo, Alagoas, 1920.

A Voz do Trabalhador, Bahia, 1921-1922.

A Plebe, São Paulo, 1917; 1922; 1932.

Correio Paulistano, 1917.

Boletim da Federação Operária de São Paulo, 1931.

\section{Publicações oficias}

Boletim do Ministério do Trabalho, Indústria e Comércio-1934 -1938 Revista do Trabalho - 1933-1939

Prontuários do Departamento de Ordem Política e Social - Dops São Paulo

n. 122: Edgar Leuenroth, 2v.

n. 710: Sindicato dos Trabalhadores da Light

n. 716: Federação Operária de São Paulo, 4v. 
n. 1123: Sindicato dos Operários Metalúrgicos

n. 2303: A Plebe

\section{Sites consultados}

www.archives.gov./exhibits/charters/charters.html

http://74.125.95.132/search?q=cache:sPvzz3eYhrVJ.www.ibge.

gov.br/home/estatistica/populacao/censo2000.

www.planalto.gov.br/ccivil_3/constituicao/constituicao34.htm www0.rio.rj.gov.br/arquivo/pdf/guia/coleção_particular_america_fabril.pdf www.vatican.va/holy_father/leo_xiii/encyclicals/documents/ hf_l-xiii_enc_15051891_rerum_po.html.

www6.senado.gov.br/legislação/ListaPublicacoes.action?id=37246 http://www.planalto.gov.br/ccivil_03/constituicao/constitui\%C.3\%A7ao.htm

\section{Enciclopédias e Dicionários}

Grande Enciclopédia Larousse Cultural. 24v. São Paulo: Nova Cultural, 1995.

HOUAISS, Antônio. Dicionário Houaiss da Língua Portuguesa. Rio de Janeiro: Objetiva, 2001.

BOBBIO, Norberto et al. Dicionário de política. v.I. Coordenação: João Ferreira. Brasília: Edunb, 2004. 


\author{
SOBRE O LIVRO \\ Formato: $14 \times 21 \mathrm{~cm}$ \\ Mancha: 23,7 $\times 42,5$ paicas \\ Tipologia: Horley Old Style 10,5/14 \\ Papel: Offset $75 \mathrm{~g} / \mathrm{m}^{2}$ (miolo) \\ Cartão Supremo $250 \mathrm{~g} / \mathrm{m}^{2}$ (capa) \\ 1̄a edição: 2015 \\ EQUIPE DE REALIZAÇÃO \\ Edição de Texto \\ Luís Brasilino (Preparação de Original) \\ Mariana Pires Santos (Revisão) \\ Editoração Eletrônica \\ Vicente Pimenta
}

